
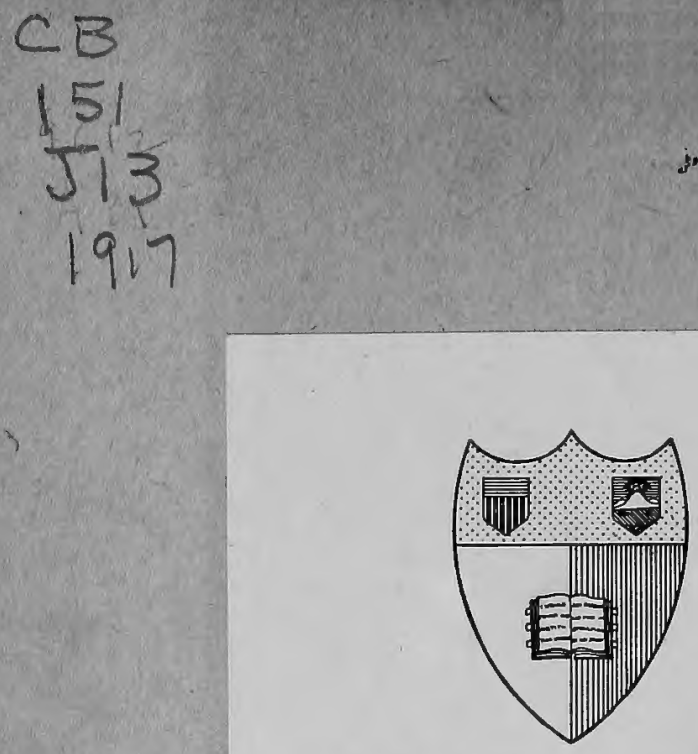

\section{Garnell Aniureraty Tithrary}

3thara, Nem Xूark

BOUGHT WITH THE INCOME OF THE

SAGE ENDOWMENT FUND

THE GIFT OF

\section{HENRY W. SAGE}

1891 


\section{งtum 01018}

thas rofory 5

MAY $1277 \mathrm{MY} \quad 9$

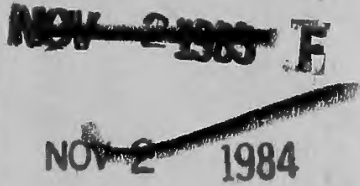

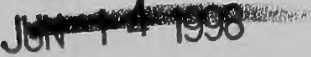

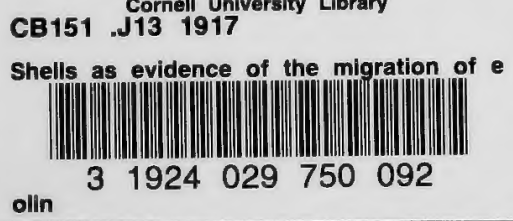




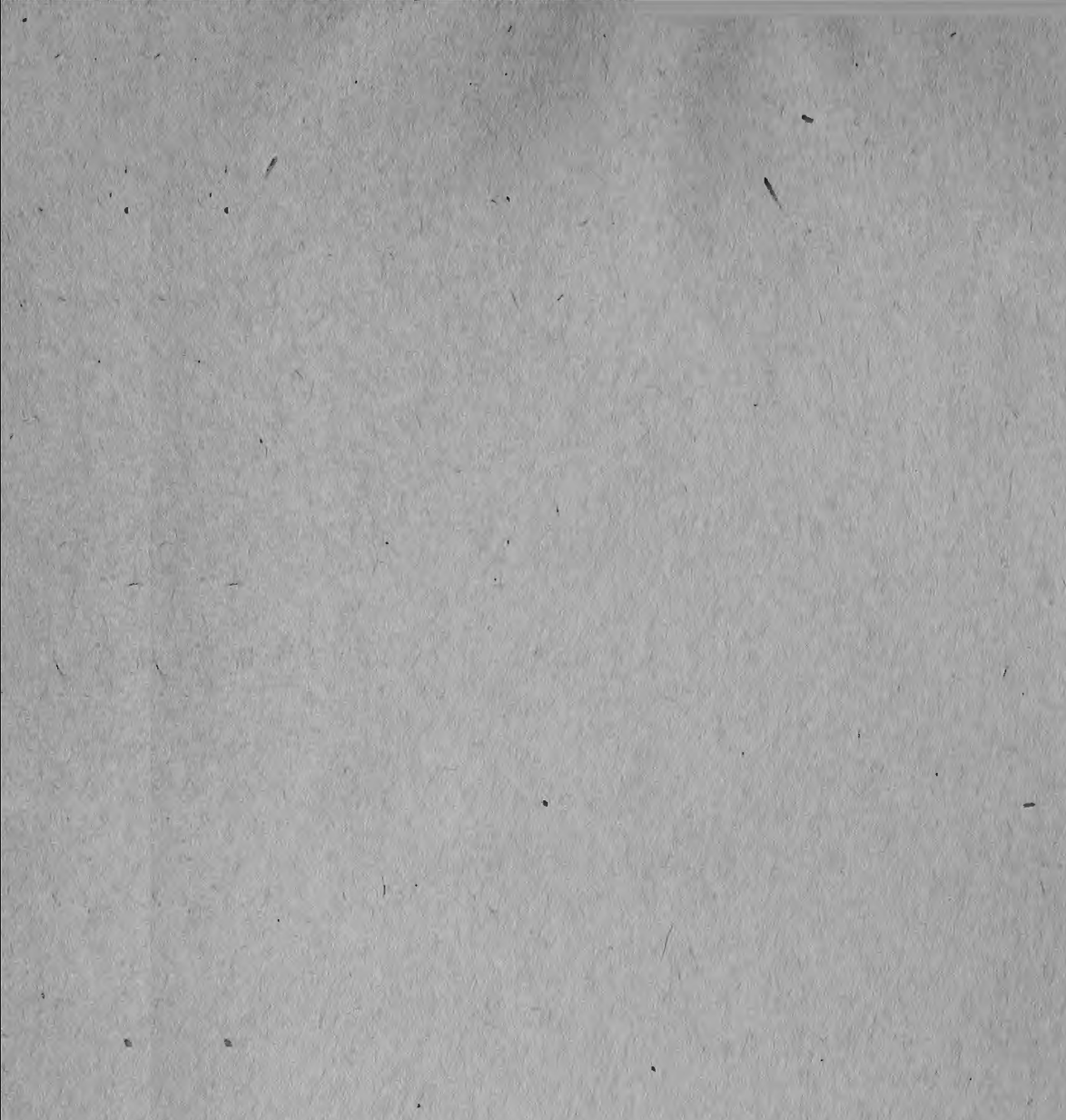


PUBLICATIONS OF THE UNIVERSITY OF MANCHESTER

ETHNOLOGICAL SERIES

No. II.

SHELLS AS EVIDENCE OF THE MIGRATIONS

OF EARLY CULTURE 
PUBLISHED BY THE UNIVERSITY OF MANCHESTER AT THE UNIVERSITY PRESS

(H. M. MCKECHNLE, SECRRTARY)

I2 LIME GROVE, OXFORD ROAD, MANCHESTER

I.ONGMANS, GREEN AND CO.

LONDON: 39 PATERNOSTER ROW

NEW YORK : 443-449 FOUR'TH AVRNUF.

AND THIRTIETH STREET

CHICAGO: PRAIKIE AVENUE

AND TWENTY-FIFTH STREET

BOMBAY: HORNBY ROAL

CAICUTTA: 6 OLD CUURT HOUSE STREET

MADRAS: I67 MOUNT KOAD 


\section{Cornell University Library}

The original of this book is in the Cornell University Library.

There are no known copyright restrictions in the United States on the use of the text. 

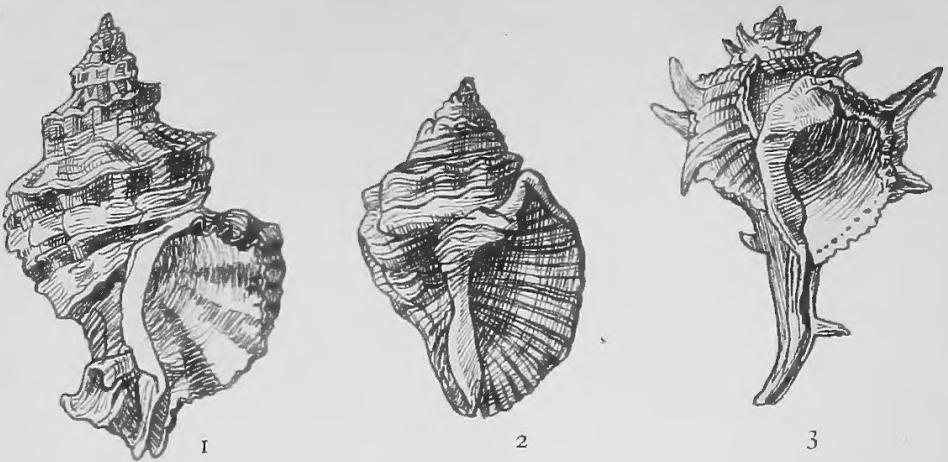

TRUMPET-SHELLS.
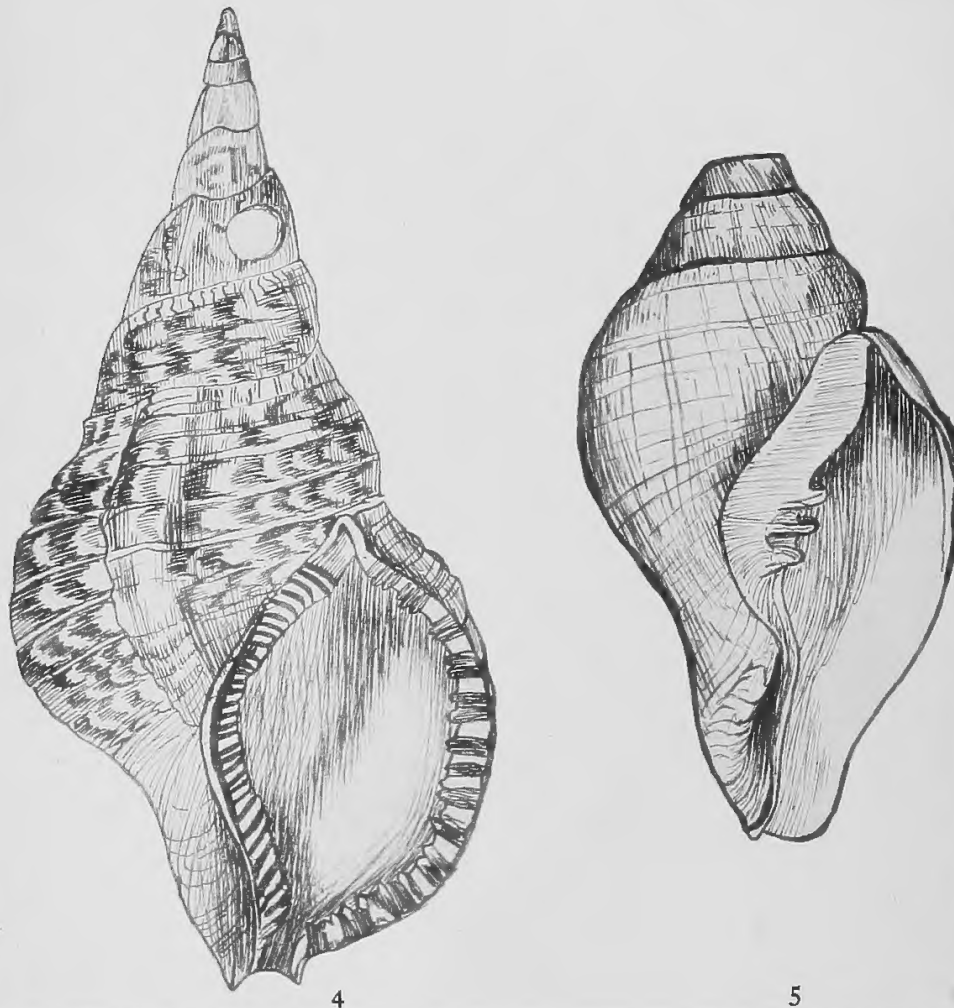

(I) Murex trunculus, L. $\frac{1}{2}$.

(2) Purpura hamastoma. Lam. $\frac{1}{2}$.

(3) Murex branderis, L. $\frac{1}{2}$ (after Reeve).

(4) Triton tritonis, L. $\frac{1}{8}$, showing blow-hole on side of spire.

(5) Turbinella pyrum, L. (the Chank), $\frac{1}{2}$, showing blow-hole at apex of spire. (From drawings by Mrs. Wilfrid Jackson.) 


\title{
SHELLS AS EVIDENCE OF THE MIGRATIONS OF EARLY CULTURE
}

\author{
J. WILFRID JACKSON, F.G.S. \\ Assistant Keeper Manchester Museum
}

Honorary Librarian of the Conchological Society of Great Britain and Ireland

MANCHESTER

AT THE UNIVERSITY PRESS

12 LIME GROVE, OXFORD ROAD

LONGMANS, GREEN \& CO.

LONDON, NEW YORK, BOMBAY, \&c. 


$$
\begin{aligned}
& C B \\
& 151 \\
& J 13 \\
& 1917
\end{aligned}
$$

$$
\begin{gathered}
A .373407 \\
\text { PUBLICATIONS OF }
\end{gathered}
$$

THE UNIVERSITY OF MANCHESTER

No. CXII. 


\author{
DEDICATED \\ To \\ MY FATHER-IN-LAW, \\ ROBERT STANDEN, \\ WHOSE VALUED FRIENDSHIP AND \\ LEARNED GUIDANCE \\ THE AUTHOR
}

HAS ENJOYED FOR MANY YEARS 


\section{CONTENTS.}

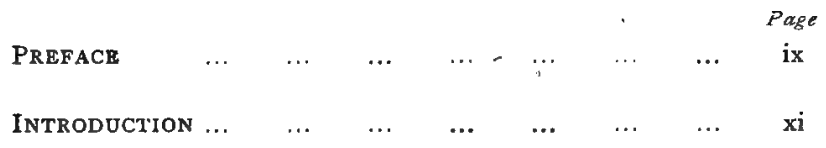

Chapter I. - The Geographical Distribution of the Shell-

$\begin{array}{lllllllll}\text { Purple Industry } & \ldots & \ldots & \ldots & \ldots & \ldots & \ldots & \text { I }\end{array}$

Chapter II. - Shell-Trumpets and their Distribution in the

$\begin{array}{llllllll}\text { Old and New World } & \ldots & \ldots & \ldots & \ldots & \ldots & 30\end{array}$

Chapter III. - The Geographical Distribution of the use of

$\begin{array}{llllllll}\text { Pearls and Pearl-Shell } & \ldots & \ldots & \ldots & \ldots & \ldots & 70 .\end{array}$

Chapter IV. - The use of Cowry-Shells for the Purposes of

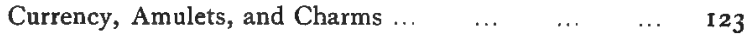

$\begin{array}{lllllllllll}\text { APPRNDIX I. } & \ldots & \ldots & \ldots & \ldots & \ldots & \ldots & \ldots & \text { I95 }\end{array}$

$\begin{array}{llllllllllll}\text { APPENDIX II. } & \ldots & \ldots & \ldots & \ldots & \ldots & \ldots & \ldots & 207\end{array}$

$\begin{array}{llllllllllll}\text { BIBLIOGRAPHY } & \ldots & \ldots & \ldots & \ldots & \ldots & \ldots & \ldots & 209\end{array}$

$\begin{array}{lllllllll}\text { INDEX } & \ldots & \ldots & \ldots & \ldots & \ldots & & \ldots & \ldots\end{array}$ 


\section{LIST OF ILLUSTRATIONS.}

I. Purple-Shells and Trumpet-Shells $\quad \ldots \quad \ldots \quad \ldots$ Frontispiece

Prge

II. Map showing the Distribution of the Shell-Purple Industry ... 2

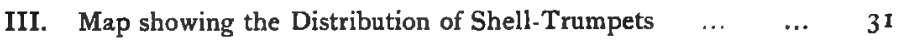

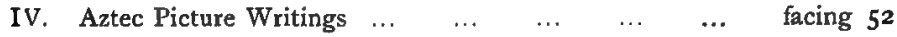

$\begin{array}{lllllll}\text { V. Maya Sculpture and Picture Writings } & \ldots & \ldots & \ldots & \text {, } & 5^{8}\end{array}$

VI. Incarnations of Indian and Japanese Gods $\quad \ldots \quad \ldots \quad \quad, \quad 62$

VII. Map showing the Distribution of the use of Pearls and Pearl-

$\begin{array}{lllllllll}\text { Shells } & \ldots & \ldots & \ldots & \ldots & \ldots & \ldots & \ldots & 7 \text { I }\end{array}$

VIII. Map showing the recorded range of Cyprea moneta and annulus $\quad$ I24

IX. Map showing the Distribution of the use of Cowries ... $\quad \ldots \quad$ r25

$\begin{array}{lllllll}\mathrm{X} . & \text { Cowries used for Currency, etc. } \ldots & \ldots & \ldots & \ldots & \ldots & 156\end{array}$

XI. Strings of Cowries used for Symbolic Messages, etc. ... $\quad \ldots \quad 162$

XII. Chinese Hieroglyphs for Cowry and Tortoise $\ldots$... $\quad \ldots \quad \ldots \quad$ I80

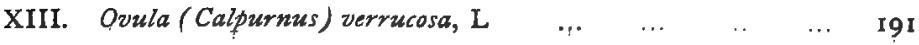




\section{PREFACE.}

In the course of my preliminary studies of "The Migrations of Early Culture," I I was struck with the remarkable cultural uses to which shells were put in widely separated parts of the world: but it was not until Mr. W. J. Perry wrote his memoir upon "The Geographical Distribution of Megalithic Monuments and Ancient Mines" " that I came to realise what an important part the search for shells had played in the diffusion of the elements of culture and in the upbuilding of civilization.

Thus it became clear that a serious attempt must be made to collect the conchological evidence. In consideration of the pitfalls into which archroologists and numismatists had fallen in the past through the failure correctly to identify the shells with which they had to deal, it was equally clear that the necessary preliminary work should be done, not by an ethnographer, but by someone with a thorough knowledge of the systematic zoology of the Mollusca.

In Mr. Robert Standen and Mr. Wilfrid Jackson the Manchester Museum is fortunate in possessing two acknowledged experts in systematic conchology. After discussing the question with them, Mr. Jackson undertook the task of collecting the ethnographical evidence relating to the cultural use of shells and of determining the specific identity of the latter. The first fruits of this preliminary survey rivalled the products of "Father O'Flynn's" intellectual achievements -

"Down from mythology into thayology, Troth! and conchology, if he'd the call."

1 Manchester University Press, I9I5.

2 Manchester Menoirs (Lit. and Phil. Soc.), November 24th, I9I5. 
Mr. Jacrson submitted a series of six reports* upon his work to the Manchester Literary and Philosophical Society and these were published in its Proceedings. The Council of the Society has courteously given him permission to republish the four more important of these contributions, with certain additions.

This book represents nothing more than the information garnered in this preliminary survey; and no one recognises its incompleteness more than its author. But I have urged Mr. Jackson to make these results more generally accessible by collecting them into a book, because they reveal the richness and the importance of this branch of ethnography. It is hoped that by appealing to the interest of conchologists and ethnologists it will stimulate some of them to join in the search for further evidence and assist in collecting and sifting the material for an exhaustive treatise.

The numerous letters which $\mathrm{Mr}$. Jackson has received from all parts of the world since he began the publication of his reports suggests that the interest in this line of investigation is real and widespread and that the wider distribution of this collection of essays will achieve the end he has in view.

Mr. Jackson has already received help from so many correspondents that it would be a difficult task to thank them all individually. But the fact that Mr. Robert Standen's help has always been given him is a sufficient guarantee of the reliability of his identification of the shells.

\section{G. Elliot Smith.}

The University,

Manchester,

30 April, igi7.

* For a list of these, sce page 2 Io of this book. 


\section{INTRODUCTION.}

In most places where shells are used it is not their decorative or æsthetic value to which primary importance is attached. Some arbitrary meaning that, in the course of ages, has come to be attached to or associated with certain shells determined the value assigned to them and impelled men to search for them far and wide and often at great peril. The cowry is widely believed to confer fertility on women and to help in the process of parturition. They are, therefore, worn on girdles by maidens, presented to them as bridal offerings, and used by sterile or pregnant women to attain these respective benefits. They are also put into graves to confer vitalising power and ensure the continuance of the deceased's existence, i.e., not merely life but also resurrection. They have been used as artificial eyes for mummies, and also as charms against the evil eye, and to bring good luck. Hence they are used for games of chance. They were probably the earliest form of currency.

Many of these attributes of the cowry were also transferred to the snail shell. Like the cowry it also was the source of life, the parent of mankind, the dwelling place of the deity who conferred the blessings of fertility, not only to mankind, but also to his crops. The murmur of the shell was the voice of the god, and the trumpet made of a shell became an important instrument in initiation ceremonies and in temple worship. In the search for these shells special significance probably first came to beattached to pearls, which, however, had been known for many ages before then to the oyster-eating makers of kitchen-middens; 
and some of the magical powers associated with shells were also transferred to pearls.

Pearl-like bodies are obtained from a considerable number of shells in addition to those of the pearl oyster; and it is significant that a special cultural importance came to be attached to most, if not all of them.

Of these the Abalone (Haliotis), the classical designation of which is "Ear of Venus," is used for ornament and currency. Its resemblance to a human ear and the serial arrangement of the perforations near its margin suggest the possibility that the custom of piercing the helix in a linear series may have some connexion with this likeness.

It is all the more suggestive when this method of perforation is found in association with the use of an earpendant made of Haliotis shell. ${ }^{1}$ Strombus gigas (the common conch), which is used as a ceremonial trumpet, produces pink pearls; and Turbinella pyrum (the Indian chank), which is the trumpet and libation-vessel of India, Thibet and China, has pink and pale red pearls. Another of this series is Tridacna gigas (Giant Clam), which is used in Oceania as well as in the West Indies for making axes and other tools, and in certain Christian churches in Europe as receptacles for 'holy water.' Venus mercenaria (Quahog or Hard Clam) is used for making shell money "Wampum" in North America. Nautilus pompilius is cut up and used for ornament and as eyes for Torres Straits mummies. It is also used as a drinking vessel in India and elsewhere.

If one asks the question how did these remarkable qualities come to be attributed to certain shells, the answer is plainly given by the collection of data brought together by Mr. Jackson.

The whole of the complex shell-cult seems to have 1 "Handbook of American Indians," Vol. I, p. I7. 
sprung out of the fanciful resemblance which a particular group of primitive men imagined they could detect between the cowry and the female organs of reproduction.

In his remarkable work "D'Amboinsche Räriteitkamer," published in Amsterdam in I74I, Rumphius informs his readers that the cowry was referred to by Ennius under the name "matriculus"; and he explains the meaning of this expression thus :- "Apud utorsque nomen accepterunt a similitudine pudendi muliebris, quod Græci Chaeron, Latini porcum et porculum vocant, cujus aliquam similitudinem refert hujus Conchaerina " (II Boek, p. I I 3). Twentyone years later Adanson, in his "Histoire naturelle du Sénégal," " referring to the use of the terms "Pucelage" and "Concha Venerea," says:- "Concha Venerea sic dicta quia partem foemineam quodam modo repraesentat: externe quidem per labiorum fissuram, interne vero propter cavitatem uterum mentientem. . . . Sunto igitur dictae Porcellanae (id est Venereae) ob aliquam cum pudendo muliebri similitudinem." Aldrov. Exang., p. 552. These ideas are still current in Japan at the present day.

That such fancied resemblances were really regarded so seriously in ancient times as to confer vital powers upon the simulating object has just becn claimed for the mandrake by Dr. Rendel Harris. ${ }^{4}$ He refers the origin of this association to. Cyprus, which also gave the cowry its scientific name, Cypraea; and in attributing the origin of the cult of Aphrodite to the magical fertilising property of the anthropoid mandrake (when worn against the flesh

2 "Coquillages," p. 65-Paris, I 762.

3 W. L. Hildburgh, "Some Japanese Charms connected with the making of Clothing," Man, Feb., I917, p. 28. (See the Appendix of this book, p. 205).

4 "The Origin of the Cult of Aphrodite," Manchester, 1916, republished" in his "Ascent of Olympus," rgr7. 
as a girdle) he emphasises precisely the same features in the development of this belief as the history of the cultural use of the cowry also reveals. In both cases a fancied likeness to the organs of reproduction was supposed to confer upon the object-whether it was the cowry or the mandrake-the magical power of conferring fertility. In both cases this influence was supposed to be exerted upon women, if they wore the amulets upon their girdle. The link of both practices with Cyprus suggests the influence of one belief in originating the other.

But though Dr. Rendel Harris has demonstrated that Aphrodite was a personification of the mandrake, this is by no means the whole of the story. It affords no explanation why Aphrodite was female, and only the slightest and somewhat fanciful reasons for the personification or the magical potency of the goddess. Nor has Dr. Rendel Harris given any reasons for the remarkable belief that it is necessary to tie a dog to the plant "to pull it up, which will give a great shreeke at the digging up : otherwise if a man should do it, he should surely die in short space after." 5

If it be assumed that Aphrodite was born of the sea foam; and reached Cyprus as a cowry, which, for the reasons that this book aims at expounding, was already the symbol of womanhood, the source of fertility, the giver of life and resurrection, the whole of the wonderful story told by Dr. Rendel Harris assumes a new meaning. The cowrybeliefs were planted in Cyprus; and there, under the influence of those horticultural ideas which, according to him, were current in the Eastern Mediterranean, the plant that also presents grotesque likenesses to the reproductive organs was regarded as the impersonation of those powers which, for similar reasons, had been assigned to the cowry.

${ }^{5}$ op. cit., p. 6. 
That the cowry shell was consecrated to Venus and that the beliefs associated with it had long been current in the Mediterranean is clear from the writings of Pliny (Bk. IX., chap. 4 ). In the Defence made byApuleius against the charge of sorcery these ideas concerning the cowry's magical properties are discussed."

Later on I shall explain how the properties of cowries became transferred in some part to pearls. In the notes on Pliny's Natural History (Bohn's Edition, I\$5j), Dr. Bostock and Mr. H. T. Riley (Vrol. II., p. 433) refer to the habits of dog-fishes ("Canes marini"), and quote from Procopius (De Bell. Pers. B. I, c. 4) the following "wonderful story in relation to this subject" :- - sea-dogs are wonderful admirers of the pearl-fish, and follow them out to sea. . . A certain fisherman, having watched for the moment when the shell-fish was deprived of the protection of its attendant sea-dog, ... seized the shell-fish and made for the shore. The sea-dog, however, was soon aware of the theft, and making straight for the fisherman, seized him. Finding himself thus caught, he made a last effort, and threw the pearl-fish on shore, immediately on which he was turn to pieces by its protector."

This legend is linked by numerous bonds of connexion with the stories of dragon-protectors of pearls and also with those relating to dolphins. It would take me too far afield to discuss its genesis here, but there can be little doubt that it is a garbled version of the dangers from sharks incurred by divers for pearls and conch shells in the Indian Ocean (see poster, p. S8). In the Far East the shark is replaced by the dragon (see postea, p. 103). I have referred to this matter only because I believe it will

"Apvlei Apologia," with Introduction and Commentary by Professor II. E. Blitler, and A. S. Owen, Oxford, I9I 4.33 and 34 , and especially the notes upon them. 
prove to be the source of the remarkable account of the necessity for obtaining the dog's help to root up a mandrake, and the explanation of the danger of this operation to man. It is, in fact, yet one more link between the beliefs associated with shells and dragons and the birth of Aphrodite.

In the appendix Mr. Jackson has collected some curious information relating to the association of a dog with the discovery of purple. Certain of the associated legends suggest that this may be another link in the complex chain of connexions between the beliefs regarding shells and those relating to the origin of Venus.

Another factor which may have played some part in the development of this belief was the Southern Arabian legend that trees might be personified, usually as women, and that it was dangerous to touch them. ${ }^{7}$ It is probable that, when the use of the cowry and pearls spread from the Red Sea to the Mediterranean, the elements out of which the wonderful Cypriote legends were compounded travelled with them.

The earliest conception of a deity arose out of these beliefs connected with the cowry. The first deities were personifications of the female principle and power of reproduction. These ideas found expression in the most primitive theologies of Egypt and Babylonia, and later in those of Dravidian India and the Mediterranean. Hathor, Istar, the village deities of Southern India, and Aphrodite were probably sprung from a common ancestry.

Elsewhere I have discussed ${ }^{\theta}$ the events that created

'See on this Schoff's "Commentary on the Periplus of the Erythræan Sea," Pp. I30-I3I.

8 "The Relationship of the Practice of Mummification to the Development of Civilisation," to appear in the Bulletin of the Ioln Rylands Library and separately under the title "Incense and Libations" (Manchester University Press). 
the intellectual atmosphere necessary for the serious adoption of beliefs such as these, which, in spite of their persistence in folklore, seem so puerile to us moderns.

It was the time when the serious attention of mankind probably first became rivetted on the problems of the nature of life and death. The realisation of the fact that sometimes the bodies of the dead did not undergo a process of dissolution when buried seems to have given support to the vague longings for a continued existence after death, with which no doubt imagination may often have played before then, and set men thinking of the elements of which death had robbed the once living body. The outcome of these enquiries was the development of ritual procedures which aimed at restoring to the corpse the breath of life (by the ceremony of opening the mouth), the waters of life (by the offering of libations), and the odour and sweat of life (by the burning of incense). But for us in this enquiry, the more important result was the body of beliefs which grew up in association with these ritual observances as the definite formulation of a coherent system of primitive biological and psychological conceptions.

The idea of the heart and the blood as the vehicles of knowledge and the will was probably much older than this, and already had probably prompted such ceremonial procedures as the drawing of blood, whether by incision or circumcision, by ear-piercing or by skin-gashing, many centuries before the first real scientific attack upon the problems of vitalism, to which I have been referring; but incidentally it helped to give more definite shape and precision to these early conceptions of the vascular system. So also the belief in the vitalising power of water was definitely more ancient; for it came to be vaguely recognised as soon as the art of agriculture first was put into 
practice. But it also became drawn into the scheme of the new body of doctrine when the possibility of water also vitalising the human body was admitted.

As a result of this new trend of thought, the belief gradually took shape, for reasons which I have explained in detail elsewhere, that a statue made in imitation of a human being or an animal, or in fact any part of such a living creature, or any article of food or furniture which the deceased needed, could be animated by means of such ritual observances as I have enumerated. These ideas added definiteness to the further conception that any object reproducing the form of a part of the body could magically influence the structure which it mimicked.

At a time when such beliefs represented the orthodoxy of religion no less than the latest teaching of science, for then the two were identical, some humble children of nature who worshipped at this dual shrine were impressed with the likeness to the female pudenda of cowry-shells, picked up no doubt on the shores of the Red Sea; and with the analogy between the process by which the mollusc extruded itself from its shell to the act of parturition. In strict accordance with the teaching of the time this discovery naturally made the cowry an amulet for insuring in women fertility and easy delivery in labour. Thus these shells became appropriate offerings to be made to girls on reaching maturity, or on the occasion of their marriage. They were also worn to cure sterility and to avert danger in parturition. These ideas spread until they encircled the world.

But the idea of encouraging the bringing to life or the conception of offspring became extended to include the power of vitalising or animating a corpse. This is an

9 "The Relationship of the Practice of Mummification, etc.,"op. cit. supra. 
integral part of the primitive train of reasoning I have been trying to reconstruct and interpret. Hence it became the custom in many places to put cowries in the grave for the purpose of insuring to the dead a continuation of existence. The fact that cowries, from their resemblance to semi-closed eyelids, were often inserted into the orbits of mummies to represent the eyes, may possibly have played some part in giving definiteness to the ancient conception of the fertilising power of the eyes, and to the crop of beliefs concerning the evil eye and the power of bringing good or bad luck, which are so intimately associated not only with a glance of the eye but also with cowry shells. These shells are commonly used for games of chance, as well as for averting the evil eye.

The development of the beliefs concerning the fertilising and animating powers of the eye and the influence of the evil eye is a very complex story, which has not yet been fully analysed and elucidated. But it seems probable that the potency of the cowry as a charm against the evil eye is to be attributed in part to the belief in its fertilising and vitalising powers and especially in its therapeutic efficacy. For as the vehicle of "soul substance" it was supposed to be able to remedy troubies due to the withdrawal of this essential element of healthy vitality. But due importance must be assigned to the fact that the assimilation of the virtues assigned to the cowry and the Egyptian eye-amulet respectively may in part be due to the fact that the cowry was actually used as a substitute for the eye.

But the use of cowries for bridal offerings and for burial ceremonies led in some places to the offering of very large collections of the shells, so as to increase the beneficent influence expected of them. Among the Baganda, for example, as many as two thousand five 
hundred cowries were given as a bridal dowry. To meet such exorbitant demands, especially in places where these shells could not be obtained locally, but had to be imported, the most valuable possessions of the people, cows, sheep and goats, were given in exchange for cowries in order to secure the social and magical advantages they were believed to bring. This was, I believe, the origin of the use of cowries as currency, and also incidentally how sheep and cattle came to occupy so definite a significance in early currencies. It may perhaps be suggestive of the original magical value of cowries that, according to tradis tion, when these shells were first introduced among the Baganda, two of them were given in exchange for a woman. At a later period two thousand five hundred of them were obtained in exchange for a cow to make the dowry, offered to the bride.

As a further illustration from Baganda of the significance attached to this shell as an animating force, cowries were placed along with the deceased king's jaw and umbilical cord. ${ }^{10}$ Cowries were also offered to twins; and if one of them died, a "clouble" was made for it, and supplied with these vitalising shells. Not only in East Africa, but also in many other places the cowry was thus brought into intimate relationship with the peculiar beliefs connected with "heavenly twins" and "doubles," with the placenta and the soul.

It also played a part in a variety of blood-letting ceremonies, such as circumcision and ear-piercing.

In my essay on "Ships as Evidence of the Migrations of Early Culture" "I called attention to the fact that the early Egyptians believed in the possibility of animating

10 In ancient times the operculum of the shell Turbo was called Umbilicus Veneris.

11 Manchester University Press, 1917, p. 29. 
their ships and converting them into living beings. They painted representations of eyes upon the bows of their ships so that, as living things, they might be able to see their way. It is possible that the ship-builders of the Arabian littoral, the Far East, and Oceania, may have had in mind this double association (as an animating power and as eyes) when they adopted the custom of attaching cowries, or other shells, to the bows of their ships.

Although Egypt has provided almost the earliest evidence $^{12}$ of the cultural use of the money-cowry, shells never played any prominent part in the lower Nile Valley. It is worthy of note, however, that the earliest gold jewelry, ${ }^{13}$ included a necklace of gold models of snailshells.

So far as the evidence at present available justifies the expression of an opinion, it seems probable that the Red Sea and the Eastern Mediterranean constitute the original home of the world-wide cult of shells. The former probably supplied the cowries and pearls and the latter the invention of the shell-trumpet and the purple dye. But there are reasons for supposing that these varied uses of shells were intimately related genetically the one with the other. The sanctity of the trumpet was probably derived in some measure from the beliefs that had grown up around the cowry. The preparation of trumpets for temple service may have played some part in the discovery of the purple dye, for one of the purple shells is a buccinum. The association of the shells which produce pearls and

12 The earliest cases of the use of the cowry may be those found in the graves at $\mathrm{La}$ Madelaine, Laugerie-Basse and Mentone. But I have suggested that although these graves are usually called "palæolithic" they may not be any older than Predynastic Egyptian graves. (See pp. I34-138).

Is G. A. Reisner, "Early Dynastic Cemeteries of Naga-ed.Dêr," Vol. I., Ig08, Plates 6 and 7. 
those used for trumpets, often in the same beds; the fact that some of the trumpet-shells yield pearl-like bodies which are put to cultural uses; and the transference to pearls of some of the magical attributes of the cowry-all of these considerations suggest the intimate genetic relations of all of these special appreciations of the value of shells. Moreover the two areas were linked together at a very remote historical period. At least as early as the Third Dynasty Egyptian sailors were engaged in maritime trafficking both in the Red Sea and the Eastern Mediterranean, and beliefs in the magical properties of shells no doubt were constantly being exchanged between the inhabitants of the shores of the two seas. Pliny mentions a legend of the relationship of the Minæans and Rhadamæans of Southern Arabia to Minos of Crete and his brother Rhadamanthus. When the intimate relations between the shell-cults of the Red Sea and of Crete are recalled one is inclined to attach some significance to Pliny's story, even though he himself was sceptical of it.

Cyprus is intimately linked with the cult of the cowry as well as with the working of copper-an association to which I shall refer later.

Crete, so far as is known, was the original home of the conch-shell trumpet and the manufacture of purple dye. The Phœenicians, with whom these things are often associated, were no more than the chief agents for distributing them abroad.

In studying the geographical distribution of the use of conch-shell trumpets, of the purple dye and of a special appreciation of pearls, one cannot fail to be struck with their associations.

Mr. W. J. Perry has called attention to the remarkable identity of the $\mathrm{e}^{14}$ geographical distribution of megalithic

14 Nanchester Memoirs (Lit. and Phil. Soc.), November 24, 1915. 
monuments on the one hand and the sites of ancient gold and copper mines and pearl beds on the other-a fact which is proving of supreme value and importance in the interpretation of the early history of civilisation. $\mathrm{He}$ made use of the Iberian Peninsula and India as demonstrations of his argument. But it applies also to the whole world, with the possible exception of Australia. De Morgan has called attention to the remarkable coincidence of the sites of megalithic monuments in the Caucasus (and on the shores of the Black and Caspian Seas) and those of old gold and copper mines. ${ }^{15}$ Baelz has made a similar observation with reference to Japan and Corea. ${ }^{16}$ Perry and I have found the same association around the head-waters of the Yenesei and along two lines leading from it respectively to the Iranian area and along the Amur to the Pacific. The same remarkable coincidences are found in the Philippines, in Celebes, and in fact throughout Indonesia.

But the same people who settled in these isolated spots to work the gold and copper, and incidentally to erect megalithic tombs and temples, were also searching for pearls and making use of shell-trumpets. When Mr. Perry has published the results of his investigations it will be seen that in the Indonesian area and New Guinea the explanation of the remarkable fact that the megalithic culture took root in some strips of coast and not in others was due to the fact that pearls were to be obtained only in those places where the evidence of these western influences is found.

In Mexico, Central America and Peru, "Tyrian" purple was used in the same localities as the shell-trumpet and where there is evidence of a special appreciation of tome I.

15 "Les Premières Civilizations," p. 404; also "Mission au Caucase," is Zeitsch. fuir Ethrologie, Bd. 42, 1910, p. 776. 
pearls. It is a remarkable fact that, according to Mrs. $\checkmark$ Zelia Nuttall, the people who make use of purple in Mexico are also famed for their gold-work, an association which has probably survived for twenty centuries. In Ireland also the king who is reputed to have first smelted gold in that island is also said to have introduced the art of making purple. Both in the Old and New Worids purple was not only made and used in the same way for staining threads for weaving, but it was also employed for colouring precious manuscripts and as a cosmetic. If it be argued that purple was invented independently in the New World it must be remembered that the method of its production is a complex and difficult process, which in itself is sufficient to raise a doubt as to the likelihood of such a discovery being made more than once.

There are reasons for believing that all these special uses of shells were spread abroad along with the complex mixture of arts, customs and beliefs associated with the building of megalithic monuments.

The earliest use of the conch-shell trumpet was in the Minoan worship in Crete. Thence it spread far and wide, until it came to play a part in religious services, Christian and Jewish, Brahman and Buddhist, Shinto and Shamanistic, in widely different parts of the world-in the Mediterranean, in India, in Central Asia, in Indonesia and Japan, in Oceania and America. In many of these places it was supposed to have the definite ritual object of summoning the deity. In the New Testament the sound of the trumpet is the signal for the resurrection. Like the cowry it was used in marriage and funeral ceremonies, in connexion with harvest rites and circumcision, in the ritual of initiation into secret societies, in the ceremonials before sacred images, in the rites of drinking (such as soma-worship and kava) and of head-hunting. 
It was also used in India as the receptacle for libations, which, as I have already mentioned, was one of the essential ritual procedures for animating the dead, and in course of time for performing the same devotional act for the deity.

Thus it was intimately interwoven into the very texture of the remarkable culture-complex of which these practices represent a few of the ingredients

Mrs. Zelia Nuttall has published a remarkable scene from an unpublished manuscript of Sahagun's, now at Florence, representing the ancient Mexicans'act of homage to the sun. Two priests offer blood by piercing their ears, two others burn incense in a characteristically Egyptian fashion, and another pair blow conch-shell trumpets. ${ }^{17}$ The use of the shell trumpet in a similar ceremonial for sun-worship in Indonesia indicates one stage in the route from Crete to America. One might multiply such illustrations almost without limit to clemonstrate the reality of the cultural bonds between these shell-elements and the rest of the sun-cult both in the New World and in the Old.

One of the most remarkable proofs of the derivation of the civilisation of America from the Old World is afforded by the representation in Maya and Aztec documents of unmistakably Indian religious scenes, often with a Far Eastern tinge. The late Sir Edward Tylor called attention to a clear example of such transference. ${ }^{18}$

Humboldt, Stolberg and Tschudi have cited others. ${ }^{19}$

17 "A Penitential Rite of the Ancient Mexicans," Archæclogical and Ethnological Papers of the Peabody Museum, Harvard University, Vol. I, No. 7,1904 .

18 "On the Diffusion of Mythical Beliefs as Evidence in the History of Culture," Report British Association, 1894, p. 774.

19 See Bancroft "The Native Races of the Pacific States uf North America," Vol. V., p. 40 et seq. 
The exploits of the American "long-nosed god," (Chac of the Mayas; Tlaloc of the Aztecs) as depicted in the ancient codices, clearly reveal that this elephantheaded deity is none other than Indra, the famous Vedic deity of India, confused with Ganesa in the process of transmission, and modified in certain respects by Cambodian and Indonesian influences."I In this book Mr. Jackson has called attention to other equally definite examples of late Hindu influence in America, in which certain of the avatirs of Vishnu reappear in America in unmistakable form.

The episodes to which he has called attention are complexly interwoven with the early mythology not only of India but also of Babylonia and Egypt. For they are part of the story of the creation and of the deluge, and intimately related to the early history of the dragon and of the Naga kings, whose palace of treasures was at the bottom of the ocean. The genesis of this remarkable story is closely connected not only with the use of the conch-shell trumpet, but also with the search for pearls. Something of the symbolism of the cowry is attached to these "pearls that grant every desire."

I have already referred to the custom, in various parts of Africa and elsewhere, of placing cowries in the grave or with the king's relics to secure the continued existence of the dead. Sometimes the cowries were placed in the mouth. The two-fold significance of the cowry-the belief in its vitalising powers and its use as currency-led to a confusion between these two properties, and was responsible for the origin of a remarkable custom. The

"O "I're-Columbian Representations of the Elephant in America," Nature, Dec. I6, rgr5.

21"Comprare M. W. de Visser, "The Dragon in China and Japan," Amsterdam, I913. 
cowry was placed in the mouth because it was supposed to be able to animate the dead: but when it came to have a new value as currency this practice lost its original significance and the use of the shell-or the actual metallic coin that superseded it-for this purpose was rationalised into the belief that it represented Charon's fare for ferrying the deceased to the other world.

In India, China and America the vitalising powers of the cowry were transferred to the pearl, which with rice (in America the so-called "native rice") was put into the mouth of the dead to insure its continued welfare. The rice had a significance analogous to that of the corvry or pearl-it was endowed with "soul substance," which was necessary to attain a future existence.

It was an early theory of pathology that all illnesses, and even death itself, were due to the abstraction of "soul substance" from the living. Thus pearls, as the bearers of vitality, were quite logically the appropriate panacea for almost every ailment. Hence pearls, and in fact all of the shells discussed in this book, occupied a very prominent place in early pharmacopoias.

In his great treatise on "The Religious System of China" (Vol. IV., Book II., p. 33I) De Groot says :"Clear reasons for pearls being considered as depositories and distributors of vital force we have found in no book, nor have we received any by word of mouth from Chinese acquaintances. Perhaps the matter must be put to the account of nothing else than Koh Hung's inventive genius . . . we must plead incompetency to solve this question." According to the old Chinese writer Koh Hung, pearls are rich in "soul-substance," in virtue of which they are not only life-conferring, but also facilitate parturition, and prevent the putrefaction of the dead body. The full information given by De Groot of ancient Chinese ideas 
concerning pearls proves quite conclusively that they share all the virtues of cowries. This provides the answer to the questions which the distinguished Dutch scholar confessed his "incompetency to solve."

In attempting to form some conception of the mode of the easterly spread of these cultural developments which originated in the Eastern Mediterranean and the Red Sea it is important to remember that it was the pearl-fishers themselves who played the chief part in the wanderings. The obtrusive role played in India by all the elements of the cult of shells; the conception of the Naga kings' home at the bottom of the sea; the stories of dragons guarding the treasure houses rich in gold, pearls and precious stones; the pearls which are found under the dragon's tongue, or in the heads of serpents and elephants; and the sanctity of shell trumpets, their use in religious ceremonial, and the reverence for and adoration of them as the attribute of some deity (Vishnu; and in the Mediterranean, Triton, Neptune and Venus) or even as its dwelling or its parent-all these facts are so many testimonies of the intimacy of the connexions which have linked these beliefs concerning shells with the deepest emotions and the most earnest strivings of the human spirit for assurance and consolation.

G. Elliot Smith. 


\section{Chapter I.}

\section{The Geographical Distribution of the Shell-Purple Industry.}

Among the many curious and ornamental uses to which shell-fish have been applied, one of the most striking and interesting is undoubtedly their employment for the production of the famous dye known as "Tyrian purple."

Much has been written concerning this dye and the subject has been discussed in its economical and philosophical aspects by numerous writers.

By far the best and most comprehensive summary of the various contributions to our knowledge of the subject is the article on Purpura by Maurice Besnier, in Daremberg and Saglio's "Dictionnaire des Antiquites." " The bibliography quoted by this author is astonishing and serves to show how extensively the subject has been treated by writers of different nationalities.

But Besnier, and the authors he quotes, deal only with the classical area of the Mediterranean. The aim of the present chapter is to trace out, as far as it is possible to do so, the geographical distribution of this interesting industry; not only in the Old, but also in the New World.

Many data relating to the use of this shell-purple are to be found in the historical records, but in some cases its former presence in a particular area can only be inferred from the finding of broken and crushed shells, which serve equally definitely to distinguish certain ancient stations for the extraction of the purple.

From the works of ancient writers, especially Aristotle 1 Vol. IV.-I., Paris. 


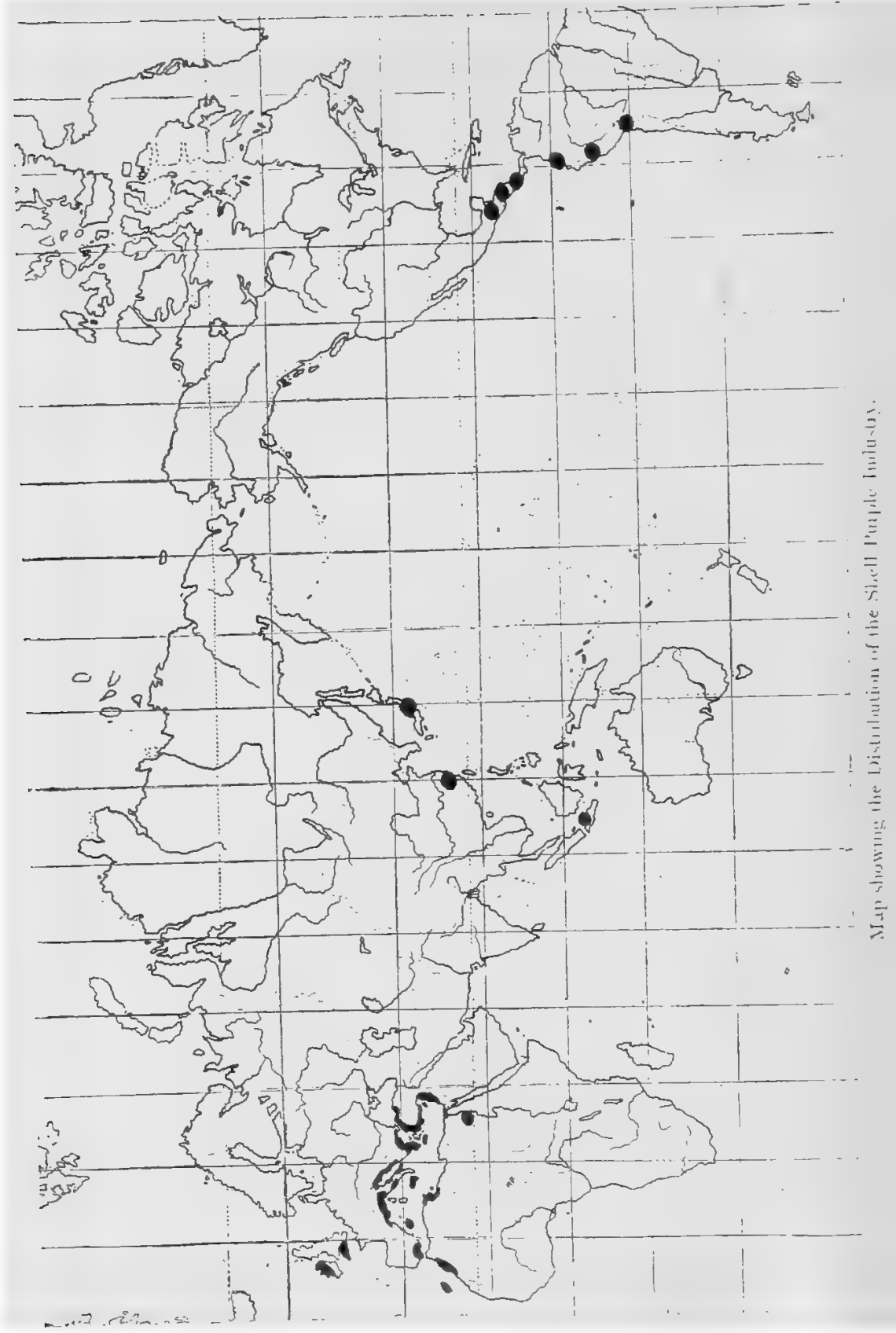


and Pliny, we learn that this famous colouring matter was in great demand among the people of the Mediterranean region. It was this purple dye, in fact, which was largely responsible for giving to the textile fabrics of the Phœnicians their world-wide reputation?

'Both Aristotle and Pliny give the details of the process by which it was procured from the shell-fish. They tell us that the precious liquid was obtained from a transparent branching vessel behind the neck of the animal and that at first the material was of the colour and consistency of thick cream. When the shells were small, many of them were bruised together in a mortar; but when large, the animal was taken out entire, usually by breaking a hole in the side of the shell, and the sac containing the colouring matter was taken out, either while the animal was still alive, or as snon as possible after death, as otherwise the quality of the dye was impaired. This was mixed with a quantity of salt, about 20 ozs. to every 100 pounds of juice, to keep it from putrefying. Three days, and no more, were allowed for the steeping process, and the liquid was then set to boil in vessels of tin or lead. The vessel was placed at the end of a long funnel, which communicated with the furnace, and while boiling the liquid was frequently skimmed to remove impurities. The proportions were about 500 pounds of material to every hundred amphoræe of water. About the tenth day, as a rule, the whole contents of the cauldron were in a liquified condition, and a fleece, freed from all grease, was then plunged in by way of a trial; but until such time as the colour was found to be satisfactory, the liquid was still kept on the boil. The wool was left to soak for five hours, and then after being carded, was thrown in again, until it had fully imbibed the colour. ${ }^{7}$

2 Pliny, "Nat. Hist.," ix., ch. 62. 
'A very curious fact concerning this dye, which was noted also to some extent by the ancients, is the transformation through which it passes on cxposure to sunlight. The fluid is at first colourless, but on exposure to the action of the sun it becomes of a bright yellow, speedily turns to a pale green, and continues to change imperceptibly until it assumes a bluish cast and then a purple red. These changes of colour, which are faster or slower according to the intensity of the sun's light, are accompanied by the production of a disagreeable foetid odour, similar to that of essence of garlic.

'This peculiarity was well known to the ancients and is referred to by Pliny. It was probably the cause of the extravagant use of perfumes by the wearers of "the purple" in classical times.

\section{TIIE SOURCES OF THE PURPLl:.}

The vague descriptions of the Greek and Latin writers has led to much discussion as to the exact species of shell-fish used in the manufacture of the dye.

Pliny speaks of two kinds that produce the purple colour. The smaller "fish," he tells us, was called the "buccinum," from its resemblance to the conch by which the sound of the buccinus or trumpet is produced; the other "fish" was known as the "purpura," or purple, and was studded with points up to the very apex, differing in this respect from the first kind.

'The earliest attempt to discover the source of the ancient purple seems to have been made by William Cole, of Bristol, in I686," who conducted experiments on shellfish ( Purpura lapillus) found on the shores of Somerset-

${ }^{3}$ Plitl. Trans. Roy. Soc. Lond., xr., pp. 278-86, and plate. 
shire, South Wales, and Ireland, in the course of which he discovered the curious photogenetic properties of the colour. These experiments were continued by other observers, including Reaumur, ${ }^{+} \mathrm{du}$ Hamel, ${ }^{5}$ Deshayes, ${ }^{1,}$ and Lacaze-Duthiers. ${ }^{7}$ The general concensus of opinion on the question is that the 'purpura' of Pliny is the Murex tranculus, or the M. branderis, of modern conchologists, while the 'buccinum' of the Roman naturalist is probably the Purpura hamastonu, all three species being common to the Mediterranean shores. The Purpurc lapillus, so abundant on the shores of Europe generally, is also likely to have been employed in the production of the inferior sort of purple?

The Ilurex-shell is almost constantly in evidence as a design upon Tyrian coins from A.D. I I 2 onwards. The shell here is quite distinct from the so-called "Murex" of pre-Alexandrine coins (circa 450-400 13.C.). The latter is not a Murex at all, but is more like a Triton, or trumpetshell; and the same shell appears on the coins of Byblus (c. 350 B.C.) and of Tarentum (c. $400-330$ B.C.). The Murex of the imperial coins of Tyre (A.D. II 2 on) is distinctly like I/Turex branderis, one of the chief purpleyielding shells.

'Whether the design of the Murex (and so-called Mlurex) on these coins had primarily any connection with the purple-trade of Tyre is doubtful, though this has been suggested by leading authorities.

* Mén dé l'Acad. des Sicuces, 17i I, pp. $168-199$ (Keatumur alsu accidentally discovered that the egg-capsules of Purpura afforded the dye in greater abundance, and with less trouble, than the animal itself).

"7oid. I736, pp. 49-68.

" "Mollusques de la Méditerranée," in "L' Expéd. Scient. de Morée, Section des Sciences physiques," iii., Paris, I832, pp. $189-192$.

7 Proc. Liby. Soi. Lond., x., 1860, pl. 579-584; also .tun. des Si $i$. Nit. Zool, xii, 1859 , pp. $5-84$, and plate. 
Judging from the associated symbols, particularly" those of the serpent, palm-tree, "mundane egg," etc., it seems to have a greater affinity with serpent and phallic worship.

At least two species of Murex, and one of Purpurr, appear to have been employed by the Phœnicians in the manufacture of Tyrian purple. Lortet records that in the vicinity of Sidon, great banks, a hundred yards long and several yards thick, occur composed entirely of broken shells of Murer trunculus," while at Tyre, according to Tristram," large quantities of crushed and broken shells of Mure.1 bronderis, have been met with. Tyre, which is reputed to have produced the best purple in Asia, is referred to by Strabo "1 as unpleasant, as a place of residence, owing to the great number of its dyeworks.

'The Tyriall method of dyeing differed slightly' from that narrated by Pliny, for the dyers merely made a bath of the liquid in which the wool to be treated was steeped for a certain time. It was then taken out and thrown into another boiler, which contained an extract from the Buccinum, or Trumpet-fish, only: This process-the so-called "purpurea dibapha"-gave to the stuffs a richer and more vivid hue. Wool submittcd to this double process was so highly esteemed that, in the reign of Augustus, each pound sold for one thousand Roman denarii, or about thrty-six pounds sterling. We need not wonder at this enormous price, considering the tedious nature of the process and the small amount of dye produced from each shell-fish. For fifty pounds of wool, the ancients used no less than two hundred pounds of the

- L. Lorlet, "La syrie d'aujourd"hui," Paris, $1 \mathrm{SS}_{3}$, p. 102.

"H. B. Tristram, "The Land of Israel," 1882, p. 48 . See also Besuier,

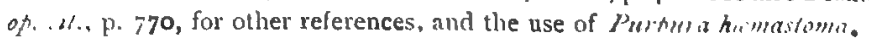

10 Stralv, xvi., c. II. p. 756. 
liquid of the Buccinum and one hundred pounds of that of the Purpura. ${ }^{11} 7$

The best purple was stated by the ancients to be exceedingly durable; and when Alexander took possession of Susa, he found among the treasures of Darius, 5,000 talents in weight of purple cloth, from Hermione in the Peloponnesus, which had been laid up there for 180 years, and yet retained all its freshness and brilliance of colour. ${ }^{12}$

The purple-bordered prætextæ of Servius Tullius, with which the statue of Fortune dedicated by him, was covered, lasted until the death of Sejanus; and it is a remarkable fact, that, during a period of 560 years, they had never changed colour. ${ }^{1: 3}$

The real Tyrian purple and purple-stuffs were essentially articles of luxury, varying in price according to times and quality."

They were always costly and vied in value even with gold itself. Consequently we find them reserved for the hangings of temples, or employed for the robes of priests and kings. ${ }^{7}$ Moses, it is recorded, used purple stuffs for the works of the tabernacle, as well as for the habits of the high priest; and among the presents which the Israelites made to Gideon the Scriptures mention purple raiment that belonged to the kings of Midian. ${ }^{4}$ The Babylonians are said to have devoted this purple to the dress of their idols, and Tertullian speaks of its use among the ancient kings of Egypt and Babylonia. ${ }^{15}$ ' It was considered a noble and sacred colour by the ancients and emblematic of the power of the gods, an idea which is explained by Besnier by the resemblance of the purple to

1 Mary Roberts, "A Popular History of the Mollusca," I851, p. I 20.

12 Plutarch, Alex., p. 36.

13 Pliny, "N. H.," viii., ch. 74.

14 "Judges," 8, 26.

1 is Tertull, De idol, p. 18. 
the colour of blood, the principle of life. ${ }^{16}$ The true reason for the belief in its vital power is suggested in the Introduction to this volume.

The mere price of the purple made the use of it a privilege of kings and priests.

By the Greeks and Romans purple was regarded as the peculiar insignia of royalty or of official distinction, such as magistrates, military officials, priests, etc. It also played an important rôle in certain of their legends.

Its use was forbidden to the common people, and laws were made inflicting severe penalties, and even death itself, upon all under the dignity of an emperor who should presume to wear it.

Though the Tyrian purple served principally as a dye for cloth, generally of wool, but sometimes of silk, it was also employed as a paint for the parchments of precious books written in letters of gold, and as a colour for inks. It had a prominent place also among the toilet requisites of the Romans and was applied in place of rouge to the cheeks and lips. ${ }^{\text {"s }}$

Attention might also be called here to the use of the purple on the sails of vessels in the earliest times. These sails were of rich colours, with floral and other designs, and were in early use in Egypt, and seem to have been bought by the Tyrians. ${ }^{19}$ The hem or border of these sails was coloured according to the rank or station of the owner. It is mentioned by Atticus that the sails of the large ship of Ptolemy Philopater were of fine linen, ornamented with a purple border. And we find the ship of Antony and

10 Besnier, op. cit., p. 777.

17 Ibid. p. 778 .

is Athenæus, xiii., ch. 8, p. 604. See also Besnier, op. cit.: p. 778, for other references.

1. Ezekiel, 27, 7. . "Fine linen, with embroidered work from Egypt, was that which thou spreadest forth to be thy sails." 
Cleopatra at the battle of Actium, distinguished from the rest of the fleet by having purple sails-a distinction which is said to have been at that time the peculiar privilege of the admiral's vessel. $0^{20} 7$

\section{THE CkNTRES OF Production AND Distribution} OF THE PURPLE INUUSTRY.

The l'hoenicians have been accredited with the invention of this famous purple as well as with that of glass, but modern investigators are depriving these 'maritime pedlars' of much of their former prestige. Glass has bcen shown to have been first made by the Early Egyptians many centuries before the probable date of the Phoenician occupation of the Mediterranean coast, ${ }^{r}$ and the credit of the invention of shell-purple has now been transferred to the Minoans of Crete. R. C. Bosanquet, in his note on "An Farly Purple-fishery" tells us that "I Ieuke, the "White Isle' (modern Kouphonisi), off the south-east coast of Crete, was an important fishing-station in antiquity. The tithes levied on the catch of fish and of purple-shell mentioned in an inscription of about 350 li.C., must have been very profitable, for the possession of the island was the subject of a long and bitter dispute among three neighbouring cities."

This island was explored in 1903 by C. T. Currelly and R. C. Bosanquet, and "among sand-hills on the north shore they found a bank of shells, some whole but mostly crushed, of Mures trunculus, which is known to have been used in the manufacture of the purple dye."

"Scattered through the heap were fragments of pottery, and of a stratile bowl which marked it as not only præ-Hellenic but præ-Phœnician. Further digging

\% J. Napier, "Manufacturing Arts in Ancient Tintes," 1874, 1'p. 287-8.

21 Brit. Ass. K'ept., 1903, p. 8r7. 
within a few yards of the heap brought to light characteristic Cretan vases of the Kamáres type, and the foundations of a house."

"The evidence shows that the extraction of the purplejuice was practised in Crete at least as early as I600 B.C." 2

Though the Phoenicians were not the original discoverers of the famous dye, they were largely instrumental in spreading the knowledge of the art among the people with whom they traded. Their two great centres of manufacture were Sidon and $T_{y}$ re and the large quantities of broken shells around these cities testify to the importance and extent of the industry.

The purple of Tyre was greatly estimated and considered the best in Asia."- The dyeworks of this city endured for many centuries until the end of the Roman Empire. The imperial manufacture of purple at Tyre is mentioned in the reign of Diocletian before 300 A.D., and in 383 A.D. the fabrication of purple of superior quality became a state monopoly."

Among other towns of Phœnicia cited as manufactories of purple stuffs are Sarepta, Caesarea, Neapolis, Lydda, and the port of Doros:" The inhabitants of the island of Cyprus also carried on this industry. The Phonicians likewise introduced the knowledge into Egypt and a private manufactory is said to have existed in the town of This, near Abydos, in the 7 th cent. A.D. But it is not clear how the purple could have been made so far from the sea.?

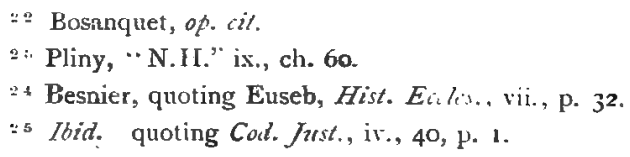

$\because$ Besnier, op. cit., p. 774. Being unable to obtain accuss to many of the works quoted by Besnier, I give these and other references on his authority. 
'The search for the purple-bearing shell-fish seems to have been one of the motives which lead the Phœnicians to explore areas further afield than their own immediate shores. The Ægean and the shores of Asia Minor were visited by these ancient mariners, and important fisheries were established at several places both here and elsewhere around the Mediterranean.

Many of their stations are made known to us by ancient writers, but the evidence of the existence of others rests upon the discoveries of heaps of broken shells.

In Asia Minor fisheries for purple-shells are cited by Aristotle ${ }^{27}$ on the coasts of Caria, and the Edict of Diocletian mentions the purple cloths of Miletus. ${ }^{28}$ There were purple dyeworks also at Phocæa in Lyclia, ${ }^{29}$ and at Hierapolis in Phrygia. ${ }^{30}$ In Troas shells were fished at Lectum and at Sigeum, ${ }^{31}$ and one of the islands of the Propontis (Sea of Marmora) was known as Porphyrione." Vitruvius mentions the purple of Pontus.: In the Ægean Sea the islands noted for purple were Rhodes, ${ }^{34}$ Nisyros (formerly Porphyris), ${ }^{85}$ Coos, Amorgos and Chios. ${ }^{36}$ According to Herodotus, Itanus, at the eastern extremity

27 Aristotle, Hist. An., v., I 5, 3. In the time of Ilomer the women of Caria trafficked in purple ( $H$. iv., I4I).

is Edict. Diocl., 24, 6 \& 7 .

a Ovid, Met., vi., 9. Thyatira in Lydia was celebrated for its purpledyeing ( $c f$. Homer, $I l$. iv., I4I); at Philippi a seller of purple from Thyatira was converled by St. Paul (Acts, 16, I4).

$30 \%$ Besnier, op. cil., p. 775 .

$\approx$ i Aristolle, op. cit.

$\because 2$ Pliny, “N. H.," v, ch. 44.

\$: Vitruvius, vii., 13.

st Tliot.

:5 Pliny, "N. H.," v., ch. 36.

so of. Besnier, op. cit., p. 775. (A1 Coos, cloths were probably dyed wilh Kermes-coccus). 
Tof Crete, was also an ancient Phouncian station and probably a factory for the purple trade. ${ }^{37}$

In Thessalia purple was manufactured at Melibcea, and a purple-establishment existed at Thessalonica in Macedonia.:

In Greece proper the two most important centres of the industry were the coast of Laconia and the Gulf of Corinth. The purple of Laconia was considered the best in Europe. ${ }^{39}$ Large heaps of Murex branderis are reported by Tristram on this coast.t0 From the island of Cythera the I'hoenicians despatched to the east and the west the celebrated "Laconian purples." + On the north shore of the Gulf of Corinth, in l'hocis, the purple-shells ware so abundant that half the population of Bulis was occupied solely in their capture."

Among other Grecian places famous for the purple industry, may be mentioned the coast of Argolis, with the port of Hermione, where the purple stuffs of Darius were prepared; ${ }^{* 3}$ the east coast of Eubaea ; Eretria and Styra in the same island; and Anthedon in Boeotia."

In the western Mediterranean, Tarentum, the modern ()tranto, was a most important station for purple from an early date. Hardouin tells us that in his time there were still to be seen the remains of ancient dyeing-houses, and that vast heaps of the shells of Murex had been discovered there. $^{4 \overline{ }}$ Aufrère, in 1789 , describes a hill called Monte

is llerod, iv. p. I51.

$\rightarrow$ of. Besnier, op. cit., p. 775 .

s s Pliny, "N. H.," ix., ch. 60.

"H. B. Tristram, op. cit, p. 48 footnote.

$41 \%$ Bewnier, op. cit. p. 775 .

421 bir.

4 Plutarch, -flex., 36 .

44 of. Besnier, op, cit., p. 775 .

45 fo footnote in Bostock is Riley's "Miny, N. 11." (vol. ii., p. 4+7). 
Testaceo, behind the Alcantarine Convent at Tarento, consisting chiefly of the shells of Murex branderis. ${ }^{4 \pi}$

The purple of the Adriatic port of Ancona is cited by Silius Italicus. Dalmatia, Istria, Venetia and Sicily, Baiz and Aquinum on the west coast of Italy, were also centres of the industry in Roman times. ${ }^{+7}$ Fischer, in his "Manuel de Conchyliologie," ${ }^{18}$ refers to the discovery at Pompeii of heaps of Purpure in the neighbourhood of many dyeworks?

Liguria provides us with interesting evidence of an early search for purple. In two caves in this region, the cave of Pollera and Caverna delle Arene Candide, both said to be of Neolithic age, Don Morelli found the broken shells of Purpura hamastona. Mosso, ${ }^{91}$ in referring to these discoveries, overlooks their true significance, and states that this mollusc has never been found in Italy, but is very common along the West African shore. On this account he suggests that the cave shells represent objects brought by early mariners returning from Africa as votive offerings for escape from the dangers of the sea. Regarding the distribution of the species in question, Mosso is somewhat at fault; it is very widely distributed in the Mediterranean, occurring on the coasts of Provence, Corsica, Sardinia, Sicily, and elsewhere. There is no reason, therefore, to assume that the cave shells came from any great distance. That they had been collected locally for the extraction of the purple dye seems evident from their broken condition, and in this connection it is of interest also to note that in the same caves Triton shells were found which had every appearance of having been

tt Lovell, "Edible British Molusca," I 884, p. 205, quoting Aufrère's "Travels."

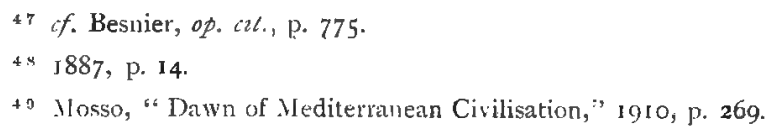


used as trumpets. ${ }^{3 n}$ The importance of this fact cannot be overlooked when one considers the intimate relationship in Crete, and other places, between the use of shell-purple for dyeing and the employment of conch-shells for trumpets. A further point is worthy of mention here, and that is the discovery of a pearl-shell (Meleagrina margaritifera), a native of Eastern Seas, on hut foundations near Reggio Emilia, N. Italy. ${ }^{\rightarrow}$ The coincidence of the occurrence of all three objects-shell-purple, conchshell trumpets, and pearl-shell-in North Italy, is most remarkable, and seems to indicate definite contact with the advanced cultures of the Eastern Mediterranean.

Regarding the geographical distribution of the purple industry further west, we find that Vitruvius makes allusion to the purple of Gaul, ${ }^{52}$ while Strabo refers to that of southern Spain, (Turdetania, near Carteia), and to the introduction of purple to the Balearic Islands by the Phonicians. ${ }^{\text {at }}$ In these islands Purpura homastoma is still used by the fishermen of Minorca to mark their linen; Murex trunculus is also known to them as yielding a fixed and permanent colour. .57

With regard to the purple of Spain, Duckworth, in his "Cave Explorations at Gibraltar," mentions the discovery of specimens of Purpura hemastoma with the apical portion fractured in a curious manner, and suggests, on

50 Mosso, op. cit., p. 363 , quoting Morelli, "Resti organici rinvenuti nella Caverna delle Arene Candide," Genova, Igor, p. III.

62 Mosso, op. cit., p. 269, quoting Colini, Atti della Societd romana d'Antropologia, x., 1904.

52 Vitruvius, vii., p. I3.

-3 Strabo, iii., 145. Carteia lay east of Gades (Cadiz) and was a colony planted by the Tyrians about B.C. II 30 , $f f$. Rawlinson, "History of Phoenicia," I889, p. 419.

it Strabo, iii., 167, of. Besnier, op. cat., p. 775.

5: Lacaze-Duthiers, Proc. Roy. Soc., x., 1860, p. 583.

s Journ. Roy. Anthrop. Tust., xli., $191 \mathrm{I}$, p. $36_{3}$, and pl. xl. fig. 3 . 
the authority of the Rev. A. H. Cooke, that the mollusc was used for the preparation of its distinctive product, the "Tyrian Purple."

In Africa, the island of Meninx (now Jerba) in the Gulf of Cabes, was famed for its purple, as well as parts of Gætulia that border on the ocean. ${ }^{57}$ The port of Zuchis, on the mainland, close to Meninx, also contained factories for purple dyeing. ${ }^{58}$ Juba II., King of Mauritania, is said to have established a manufactory of this dye, known as "Gætulian Purple" in the Purpurariæ, or "Purple Islands" (probably the Madeira group)..$^{59}$

In the British Isles the art of purple dyeing from shellfish seems to have been known from very early times. That it dates from pre-historic times in Ireland seems evident from the discoveries made in 1895 by $R$. Standen and his co-workers of "Purpura-mounds" associated with "Kitchen-middens" of Patella vulgata, Littorina littorea, etc., at Portnafeadog (or Dogs Bay), Connemara, West of Ireland.

In his paper on the subject ${ }^{30}$ the author states that the shells of Purpura lapillus in the "Purpura-mounds" had all been broken in a peculiar manner. "In each case the apical whorls were smashed, leaving the lower whorl with mouth intact, and in some cases portions of the second and third whorls remaining along with the columella." The broken Purpura shells were present in enormous quantities and one large heap measured 55 yards in length, I 5 yards across the broad end, and 3 yards across the narrow end. Two hundred specimens were picked up from one square foot.

Heaps of the shells of the same species in a broken ${ }^{5} 7$ Pliny, "N.H.," ix., ch. 60.

${ }^{6} 8$ Strabo, xvii., 835 .

${ }_{58}^{8}$ Pliny, "N.H.," vi., ch. 36 .

o0 Journal of Conchology, viii., 1896, p. I87. 
condition and associated with other edible kinds, bones of animals, stone implements, and flint flakes, have since been noticed by several observers round the Donegal coast in sites similar to those at Dogs Bay.

Regarding the Dogs Bay discovery, F. J. Bigger, one of the I 895 party, writes : " Shells of this species, either whole or broken, had seldom been observed among other remains in sandhills, and certainly never in any quantity; but here there was a large heap, all broken, which seemed to have the same connection with the sites as the shells of the other species."

Enquires were made in the neighbourhood as to whether the Pufura was now used for any purpose, but not even the oldest inhabitant could recollect hearing of its being used as food, or bait, or in any way whatever.

Large quantities of broken shells of Pupura lapillus, together with rounded pebbles of quartz, large enough to break them, have also been found by the Rev. K. Ashington Bullen in "Kitchen-middens," close to the Late-Celtic cemetery, at Hariyn Bay, North Cornwall, "iz

These discoveries of broken Purpura shells in the British Isles have led to much discussion as to the possibility of their use as food like the other associated species. This question, however, has been ably dealt with by Standen and Bigger, who point out the unsuitability of this species either for food or bait, whereas the associated species, Patilla and Littorina, may be used for either purpose. They suggest, therefore, that the Purpurcr shells may have been broken in order to extract the animal for the rich purple it affords. A similar suggestion is put forward by the Rev. R. Ashington Bullen, ${ }^{\text {RS }}$

"1 Proc. Ray. Ioish Aciulemy, 3rd Ser., v.. I899, p. 437.

$\because=$ Proc. Alalai. So4., r., 1902, p. I85, and Trans. S. Eastirn Cinion of Sil. Soc., 1903.

- llial. 
Apart from the evidence afforded by the Mediterranean instances of broken shells, this interpretation receives strong support from the interesting statement made by Lenormant and Chevallier in dealing with the purple industry of the ancients. 'According to these authors the Phœnicians "also procured from the British Isles a dark shade, called 'black purple,' but it has not yet been ascertained with certainty what species produced it." of 7

Further evidence of the antiquity of purple in Ireland is furnished by Wood-Martin in his "Lake Dwellings of Ireland." ${ }^{\prime}$ On p. 104 of this work the author tells us that the MS. Book of Ballymote contains an ancient Irish poem, which states: "It was Tigearnmas who first established in Ireland the art of dyeing cloth of purple, and many colours."

This King-variously given as Tighernmas and Tiernmas-is alleged to have reigned about 1000 B.C., and "was the first that smelted gold in Ireland." 66

We have many instances of the survival of this purple industry in the British Isles. Johnston ${ }^{67}$ tells us that the Venerable Bede, who wrote in the eighth century, mentions the art as known in his time, and he was familiar with the beauty and permanency of the colour. ${ }^{68}$ The same fact is mentioned by Richard of Cirencester ${ }^{69}$ and also in a translation of Higden's "Polichronicon" made in the year $1387 . .^{70}$

'Purple shell-fish were largely employed from the I6th 64 "Manual of Ancient History of the East," London, 1870, ii, , p. 2 I4.

- 5 Dublin and London, 1886.

" Kinahan, "Geology of Ireland," 1878, p. 340.

67 Johnston, "Introduction to Conchology," I850, p. 72.

- " "Hist. Eccles. Gent. Ang." lib. i., c. L.

6 0 "Desc. of Britain," 28.

;o Book i., ch. $3^{8}$ of "Bretayn." 
to I 8 th centuries for marking linen in Somersetshire, Cornwall and other parts of England, as well as in Scotland, France, Norway and other parts of Europe. ${ }^{71}$

Purple robes were in frequent use in Ireland during ancient times. In the tale of Eithne and King Cormac, quoted by Whitley Stokes in his introduction to the Irish "Tripartite Life of St. Patrick," i, p. xxxviii, fifty maidens in purple mantles are mentioned. In the "Book of Rights," p. 65, cloaks trimmed with purple are noticed; at p. 87 , the King of Ara is said to be entitled to six purple mantles from the King of Erie; at p. 147, the stipend of the King of $\mathrm{Ui}$ Breasail includes three purple cloaks. We are told that Medb presented Ferdiad with a girsat cocra or purple waist scarf to induce him to fight Cuchulaind. ${ }^{72}$

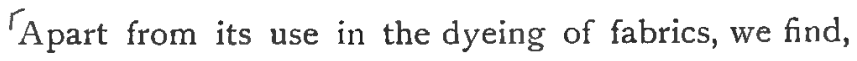
in Miss Roberts' work, ${ }^{73}$ some interesting particulars as to the employment of Tyrian purple, in Britain and elsewhere, in dyeing parchments, or vellum. This was done for the purpose of rendering still more splendid the manuscripts, which were adorned with gold and silver letters. This magnificent and expensive style of writing on purple vellum was appropriated to Biblical manuscripts, and the libraries of princes. As examples of this class of work we have the book of the Gospels, which Louis the Pious gave to the monastery of St. Medard, at Soissons, now in the royal library of France, and the Book of Prayers, bound in ivory, and studded with gems, formerly belonging to Charles the Bald, but now in the celebrated Colbertine Library.

Similar manuscripts were also occasionally made in "1 See papers by Cole, Reaumur, du Hamel, Deshayes, and LacazeDuthiers, 1. c.

${ }^{72}$ F. J. Bigger, Proc. Roy. Irish Acad, 3rd ser., iii., I896, p. 730.

${ }^{73}$ Roberts, op. cit., Pp. 123-4. 
England. The famous Wilfred ordered a copy of the four Gospels. to be written for the church of Ripon, in letters of the purest gold, upon leaves of parchment, purpled in the ground, and variously coloured on the surface.

The Gregorian Bible, presented by a monkish missionary and his companions to the first Christian church erected at Canterbury, was also of a similar description.

Eastward of the Mediterranean we find several indications and curious survivals of this ancient purple industry.

According to Johuston, ${ }^{74}$ the Chinese make use of a similar dye. The extreme conservatism of Chinese tastes suggests that the art is no recent importation amongst them. Bancroft ${ }^{75}$ also gives an interesting quotation regarding the use of shell-purple by the Chinese settlers in the Malay region. He tells us that "Mr. John Nicuhoff relates that 'abundance of purple snails are found in the islands over against Batavia. They are boiled and eaten by the Chinese, who have a way of polishing the shells, and prick out of the middle of the snail a certain purplecoloured substance which they use in colouring and making red ink." "

That the purple was appreciated and sought for by the ancient inhabitants of Japan is implied from the discovery of certain broken shells in their "Kitchenmiddens." Professor Edward S. Morse, in his paper on "Shell Mounds of Omori," tells us that along with such species as Fusus inconstans, Hemifusus tuba, Eburna japonica, etc., the shells of Rapana bezoar were exceedingly abundant in the mounds and of large size with massive

$7 \pm$ Johnston, op. cit., p. 74 .

75 Bancroft, "Philosophy of Permanent Colours," i., r794, pp. 93-4.

To Menoirs of the Science Dept., Uniz. of Tokio, Japan, vol. i., pt. i., No. $2539,1879$. 
shell. Many of the specimens of this species had a portion of the body whorl broken away "as if for the purpose of more conveniently extracting the animal." The same species is recorded from the Okadaira Shell Mound at Hitachi by J. Jijima and C. Sasaki," who also call attention to the fact of the specimens having almost ralways an irregular opening in their body whorl as if made for facilitating the extraction of the animal.

Why the shells of this particular species should be broken and not the others is remarkable. The idea that such a procedure was solely to facilitate the extraction of the animal for food purposes does not appear to be conclusive. A far greater significance is attached to such an occurrence when one considers that Rapana beroay belongs to the purple-bearing family, Muricide, and is closely allied to Purpura. It is not improbable, therefore, that the object in breaking the shells was to obtain purple for dyeing purposes. That these ancient people were not wholly ignorant of textiles is evidenced by the occurrence of spindle-whorls associated with the pottery and shells of the mounds.

In the New World we have ample evidence of the practice of this ancient industry at several places in Central America, especially in the 17 th and 18 th centuries. Here the species employed is Purpura patula, which is plentiful in the West Indies, and on rocks between high and low tide levels on both the Atlantic and Pacific coasts of Central America. It resembles the Purpura hcemastoma of the Mediterranean, one of the species used by the ancient Tyrian dyers, and which, as previously mentioned, is still used by the Minorcan fishermen to mark their linen. ${ }^{78}$ ?

it Ibid., Appendix: No. 2542, 1882.

is See Lacaze-Duthiers, "Nat. Hist. of Purple of Ancients," Prat. Roj. Soc. London, x, 1860, p. $58_{3}$. 
D'Argenville, in his "Conchyliologie (I742, p. I8I), states that the "Conque Persique" is made use of both in Panama and Guatemala for dyeing purposes and, on that account, is called "Poupre de Panama." The "Conque Persique" (Purpura persica) inhabits the Indian Ocean, and was distinguished from the Purpura patula of the Pacific coast by Brugière in I 789 and Lamarck in 1803.

In 1744, Don Antonio de Ulloa saw at S. Elena, in what is now Ecuador, and also at Nicoya (Costa Rica), purple colour produced from sea-shells. He describes the process in his "Physical and Historical Account of Southern and North-Eastern America" as follows: "On the coasts belonging to the province of Guayaquil the finest purple is found. The animals from which it is derived are contained in shells, about the size of walnuts, and live on rocks washed by the sea. They contain a juice or humour, which is taken out, and yields the true purple. . . . Cotton, thread, and other delicate materials are dyed with it. It gives a lively and durable colour, which does not lose its lustre by frequent washings, but is rather improved thereby, and does not fade through long-continued use and exposure. Near the port of Nicoya in the province of Guatemala the same kind of shell-fish is found, and is used for dyeing cotton..... Various processes are employed for extracting the juice or humour. Some kill the animal. They take it out of its shell, and, having laid it on the back of the hand, press and squeeze it with a knife from the head to the tail, and then separate the expressed juice, the rest of the animal matter being thrown away. They treat in this way a number of animals until they have a sufficient quantity of juice. They then draw through the thread which they wish to dye, and no more is required..... Others express the juice without killing the animal. They do 
not take it entirely out of the shell, but only press it so as to cause a certain quantity to be ejected, with which the threads are dyed. The shells are then laid again on the stones from which they were taken. They recover, and after some time give a fresh quantity of juice, but not so much as the first time." i"

Thomas Gage, ${ }^{\text {ro }}$ an earlier observer, gives an account as follows: "About Chira, Golfo de Salinas, and Nicoya, there are some farms of Spaniards, few and very small Indian Townes, who are all like slaves employed by the Alcalcle Maior, to make him a kind of thred called Pita [agave fibre], which is a very rich commodity in Spain, especially of that colour wherewith it is dyed in these parts of Nicoya, which is a purple colour; for the which the Indians are here much charged to work about the Sea shore, and there to finde out certain shels wherewith they make this purple dye."

Of the process of purple dyeing as practised in more recent times by the natives of Nicaragua, Squier." gives us the following account: "Some of the cotton fabrics manufactured by the Indians are very durable and woven in tasteful figures of various colours. The colour most valued is the Tyrian purple, obtained from the murex shell-fish, which is found upon the Pacific Coast of Nicaragua. This colour is produced of any desirable depth and tone, and is permanent; unaffected alike by exposure to the sun and to the action of alkalies. The process of dyeing the thread illustrates the patient assi-

: Translation quoted by Dr. E. Schunck in "Notes on the Purple of the Ancients," Jou'r. Chem. Soc., xxxvii., I880, Trans., pp. 6I3-614.

". The English-American, his Travail by Sea and Land : etc.," London, 1648 (quoted by MacCurdy, Mlem. Comn. Aiad. Arts \& Sciences, iii.. New Haven, March, I9II, p. 160).

"1 "Nicaragua, its People, Scenery, Monuments, etc.," 1852 , vol. i.," p. 286. 
cluity of the Indians. It is taken to the sea-side, when a sufficient number of shells are collected, which being dried from the sea water, the work is commenced. Each shell is taken up singly, and a slight pressure upon the valve which closes its mouth. [operculum] forces out a few drops of the colouring fluid, which is then almost destitute of colour. In this each thread is dipped singly, and after absorbing enough of the precious fluid, is carefully drawn out between the thumb and finger, and laid aside to dry. Whole days and nights are spent in this tedious process, until the work is completed. At first the thread is of a dull blue colour, but upon exposure to the atmosphere acquires the desired tint. The fish is not destroyed by the operation but is returned to the sea, when it lays in a new stock of colouring matter for a future occasion."

In connection with the Nicoya industry, the observations of C. V. Hartman ${ }^{\text {s2 }}$ are interesting. On one of his recent expeditions to the Pacific Coast of Costa Rica, he visited Guanacosta, where he saw an Indian woman from Chiriqui wading in the water in search of Purpura. She would put the shell to her mouth and blow into it, causing the snail to discharge a greenish yellow fluid, which she applied to white cotton thread. The fluid in drying turns to purple.

An even more interesting account of the existence of purple dyeing in the New Worid is that recently published by Zelia Nuttall, viz., "A curious survival in Mexico of the use of the Purpura shell-fish for dyeing." " In this paper an excellent description is given of the dyeing of cotton thread for the manufacture of purple skirts worn by the women of Tehuantepec. In the spring the cotton

Q: See Mac Curdy, op. cit., p. 160, quoting Frartman.

* Putnam Anniversary Volume, 1909, pp. 368-384. 
skeins are taken in boats by the fishermen along the coast northward, where suitable habitats of the caracol or seasnail are visited. "Slipping a skein over his left wrist, the fisherman wrenches one sea-snail after another from the wet rocks, blows on it, causing it to exude the dyestuff, which resembles a milky froth, and then dabs the cotton thread with numerous shells in succession, until it is thoroughly saturated. When each shell had yielded its small supply of liquid dye, some fisherman pressed it to the rock and waited until it adhered thereto, but others laid the shell in a pool. When treated thus the same shells yielded a second, though diminished supply, when the rocks were visited on the return journey" (pp. 369-370).

The late Professor von Martens, in a paper read before the Berlin Anthropological Society on October 22nd, $1898^{84}$ deals very thoroughly with the subject of purple dyeing in Central America. In this valuable contribution he discusses the evidence as to whether the employment of the shell-fish for dyeing purposes was an independent and precolumbian invention of the Indians, or was introduced by the Spaniards. He rightly concludes that it was practised in America in pre-historic times.

Through Professor Edward Seler, Professor von Martens obtained information of the Tehuantepec industry, and was shown not only a purple skirt, which the Zapotecan women wear only on special occasions and which but few can afford, but also kerchiefs with purple stripes such as are worn by the Huave Indians, to the south-west of Tehuantepec.

Professor von Martens found, on examining some of

"1 Verhand. Berliner Gesell. fuir Anthrop. Ethnol. u. Urgesch, $\mathrm{x} 998$, pp. $482-6$. 
the only precolumbian textiles in existence, those of Peru, preserved in the Royal Ethnographical Museum in Berlin, a garment and some bands with narrow stripes, the colour of which is identical with that of the Huave kerchiefs. $\mathrm{He}$ also noticed the same in textiles from Chimbote, Peru (Bolivar collection). ${ }^{\mathrm{R}}$

In further support of his conclusion that the dye of the l'urpura shell was used in America in precolumbian times, Professor von Martens refers to the use, alongside of each other and in the New and Old World alike, of two other shell products, viz., the conch-shell trumpets and pearls. The interesting data concerning these two products, and the evidence they afford in the spread of certain elements of culture, will be dealt with in later chapters. It will be sufficient here to point out that Professor von Martens' conclusion is strikingly confirmed by the further evidence produced by Mrs. Nuttall.s She tells us that in the ancient Mexican Codex named after her, a beautiful purple paint is profusely used. This Codex "contains pictures of no fewer than thirteen women of rank wearing purple skirts, and five with capes and jackets of the same colour. In addition, forty-six chieftains are figured with short, fringed, rounded purple waistcloths, and there are also three examples of the use of a close-fitting purple cap." Priests and other personages are also represented whose bodies, and sometimes faces, are painted purple, and throughout the Codex the same colour appears in combination with others in ornamental designs and figures.

Mrs. Nuttall points out further that "the shade of the purple paint used is identical with that of the purpura dye, and until it is demonstrated to us that the native

\footnotetext{
45 Von Martens, op. cit., p. 485.

so Nuttall, op. iti., pp. $3^{80-1 .}$
} 
artists obtained this colour from some now unknown mineral or vegetal dye, it may be assumed that they also used the purpura dye in preparing their paint and in depicting personages with body paint and garments dyed by means of the same shell-fish." ${ }^{87}$

The employment of purple paint in ancient Mexican manuscripts is decidedly interesting and recalls the use made of this famous colour for dyeing the ecclesiastical parchments in Europe during early times. In like manner the purple facial-painting of the Aztecs, as demonstrated by their manuscripts, is a curious parallel to the $\mathrm{cm}$ ployment of purple for the cheeks and lips in Roman times.

Some further imporfant evidence of the use of shellfish in dyeing in precolumbian times has lately been furnished by the discovery of broken J'urpura shells in Inca graves in North Chile. L. E. Adams, in his "Conchological Notes from Chile and 13razil," mentions the occurrence of broken shells of Purpura in a "kitchen midden" on the steep mountain-side at Pisagua. These were discovered, along with other marine shells, in the course of road improvements, the road in question being found to traverse an Inca burying ground. Adams states : "Several human skeletons were lying on or just below the surface, all in the characteristic cloubled-up attitude; they had been buried wrapped up in a coarse grass matting. None of the skulls were perfect, the upper and lower jaws were all missing, as if the excavators had taken them to study the dentition."

"In addition to human remains, were skulls of some large species of dolphin, skulls of sea-lions (? Otaria jubata), the rib of a small whale, and dogs both large and

' Nuttall, op. cil., p. $38 \mathrm{r}$.

- foum. of Conchology, xis.. 1915, p. 349. 
small ; to one of the latter, which was enveloped in matting, the reddish hair was adhering."

It is suggested by Adams, and by H. B. Preston who identified the various shells, that the Purpura were the refuse of food, the shells having probably been split open to obtain the animal whole. The breaking of the Purpura, however, seems to me to possess a greater significance.

Judging from the occurrence in the Old World of similar heaps of shells broken in the same peculiar manner in order to obtain the purple product, it is not at all unreasonable to assume that here we have an indication that the Incas. were cognizant of the art of purple dyeing by means of shell-fish. This discovery, therefore, is most valuable, as it at once disposes of any further doubt concerning the precolumbian use of shell-fish for dyeing purposes, and $d_{v}$ moreover, provides us with interesting information as to the precise source of the purple colour in the beautifully preserved textiles of Peru.

As already pointed out, this purple industry is closely associated, both in the Old and in the New World, with the appreciation of pearls and the use of the artificially devised conch-shell trumpet. Each of these cultural elements had their origin in the Eastern Mediterranean. Stations for the purple industry, as we have seen, were established by the early Mecliterranean mariners in several places in the Old World. In addition, we find that an intimate relationship existed between this art and skill in weaving, as well as the mining, working and trafficking in metals, such as gold, silver and copper.

In the New Worlu the purple industry is associated with similar pursuits.

As Mrs. Nuttall points out, "we find that, in precolumbian times, the Zapotecs, whose descendants still use the purpura, were famed as miners, as workers in 
copper, gold and silver, as weavers, and as enterprising traders who travelled far and wide, trafficking with these products and the cocoa-bean." ":!

Similarly, the ancient Chiriquians of the Panamic region, whose descendants, the Guaymis, still go in search of the Purpura shells, were metal workers in gold, copper and their alloys.

That all the foregoing, in addition to other associated elements of culture, could have developed independently in the Old and in the New World is inconceivable. In Mexico, Central and South - America, the aborigines unanimously disclaim their independent discovery of all arts and industries and assign their introduction to strangers of superior culture from distant and unknown parts. ${ }^{.0}$

As Mrs. Nuttall justly concludes, "it seems almost easier to believe that certain elements of an ancient European culture were at one time, and perhaps once only, actually transmitted by the traditional small band of . . . Mediterranean sea-farers, than to explain how, under totally different conditions of race and climate, the identical ideas and customs should have arisen."

The peculiar and distinctive character of the shellpurple industry is in itself sufficient justification for this conclusion, as it is altogether unlikely that different people could have adopted so remarkable a custom, along with identical methods of extracting the precious purple matter from shell-fish.

In glancing over the facts quoted in this chapter it will be at once apparent that many gaps exist in the geographical distribution of this remarkable industry. These lacunæ, however, are probably more apparent than

\footnotetext{
Nutlall, op. iit., p. $38 \mathrm{I}$.

o lozd. pp. 382-3.

"1 Thid. pp. 383-4.
} 
real, and are due rather to lack of precise information, than to an entire absence of the art in certain places.

I have been unable so far to trace any indication of this industry in the numerous islands of the Pacific."

Judging from the presence in these islands of other associated elements of culture, such as shell-trumpets and pearls, acquired by direct or indirect contact with the Eastern Mediterranean, it seems possible that the art of dyeing by means of shell-fish also spread in this direction. Various circumstances, however, may have prevented the adoption of so curious a custom.

It must be remembered that particular kinds of shellfish were necessary for the production of the purple, and much would depend on the presence of one or other of these forms in the seas round the islands of the Pacific. Murex and I'urpura certainly occur in their neighbourhood, but they are totally unlike the purple-yielding shellfish of the Mediterranean-a fact that may have led to their being disregarded by the bearers of the particular culture. It is only when we reach the American coast that we find a form of shell-fish analogous to that used by Tyrian dyers of ancient times.

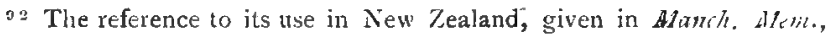
Vol. 60, 1915, No. 1, p. 36, is founded on a misunderstanting. 
Chapter II.

\section{Shell-Trumpets and their Distribution in the Old and New World.}

The wide-spread use of shells as horns or trumpets is of very ancient origin.

The Latin word Buccina, or Buccinum, a trumpet, was indiscriminately applied by the ancients to almost every kind of spiral univalve shell. Amongst the Greeks the large Triton nodiferus, Lam., was the trumpet used in land-and sea-fights, as well as for setting the watch and calling together assemblies of the people. ${ }^{1}$

Triton, Neptune's trumpeter, is generally depicted with a large conch shell in his hand, with which it is fabled he convened the river deities around their monarch. It is wreathed, like those called Sikanos, or Sea-horn, common to India, Africa, and the Mediterranean, and still used as trumpets for blowing alarms or giving signals."

Itanian coins (circa 200-67 B.C.) have the figure of a sea-god or triton carrying a trident and blowing a conchshell. $^{3}$

Triton holding a conch with both hands and blowing into it is also seen on the coins of Agrigentum, Sicily (before B.C. 406.)

Pliny tells us that a deputation of persons from Olisipo [Lisbon], that had been sent for the purpose, brought word to the Emperor Tiberius that a triton had

1 Jeffreys, "Brit. Conch.," iv., I 867 , p. 284.

2 Mary Roberts, "Popular History of the Mollusca," 185I, p. 97.

3 B.V. Head, "List, Numorum," I887, p. 398.

4 Ibid. p. I06; and "B.M. Cat. Greek Coins: Sicily," 1876, p. 15. 


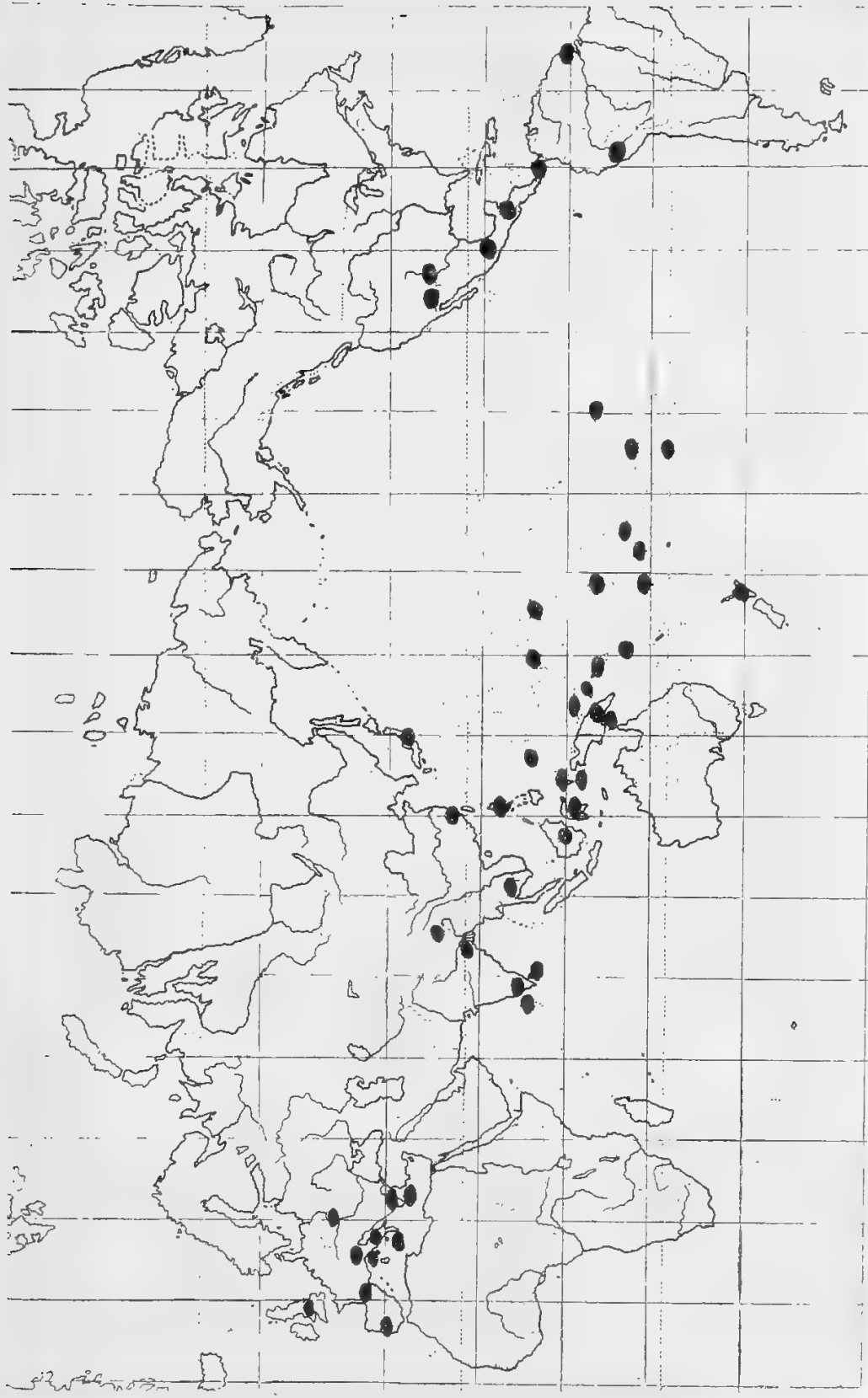


been both seen and heard in a certain cavern, blowing a conch-shell, and of the form under which they are usually represented. ${ }^{5}$ And one of the Scholiasts on Homer says, that before the discovery of the brazen trumpet by the Tyrrhenians, the conch-shell was in general use for that purpose. ${ }^{0}$

The larger species of Buccinum is still used by Italian herdsmen in directing their cattle. It is also common in North Wales, Staffordshire, Lithuania, and Muscovy, where they are also applied to pastoral purposes. ${ }^{7}$ At Casamicciola, in the Island of Ischia, conch shell trumpets are sounded to scare away thieves and birds from the vineyards and gardens." Sicilian fishermen use Triton nodiferus as a trumpet, and Vérany tells us that at Nice this shell, with a hole at the top, serves as a trumpet for the fishermen and country people, and that the braying noise produced by it renders this unmusical instrument indispensible for the old-fashioned charivari, which he describes as a deafening serenade to signalize the marriages of widows and ill-assorted couples. ${ }^{9} \mathrm{~A}$. Mosso relates that the Triton is still sounded in church at l'iedmont, and that during the services in Holy Week at Chieri, when the choir was singing the psalms, and a table was struck with sticks during the so-called tenebræ of the sepulchre, the sacristan gave him a Triton shell to sound..$^{10}$ Issel also relates that during the services of

" Pliny, "Nat. Hist.," ix., ch. 4. (Bolnn's El., vol. ii., p. 362).

"Ibid. (footnote by Bostock \& Riley).

" Roberts, op. cit., p. 97, and Lovell, "Edible Prit. Moll," 1884, p. 194.

" Lovell, op. cit., p. I94, quoting Dr. Wm. Russell, "Memories of Ischia," Nineteenth Century, Sept., 1883 .

" Jeffrey, op. at., iv., I867, p. 303 .

10 Mosso, "The Dawn of Mediterranean Civilization," I91o, p. 365. 
Holy Week in the Cathedral of Genoa, the Triton nodiferus used to be sounded."

In his paper on "Purple Dyeing in Central America," 12 Professor von Martens refers to the survival of the use of shell-trumpets at the present day in certain localities in southern France, Elba, Corsica, and Sicily, for the summoning of fishermen and field labourers.

In the 18 th century the Corsican militia, under Paoli, employed them instead of drums and trumpets. ${ }^{13}$

Triton shells are still in common use in Crete, especially among the village guards, as a means of raising an alarm or calling for help. ${ }^{1+}$

As in the case of Shell-purple, ${ }^{15}$ the island of Crete figures very prominently in the early use of shell-trumpets.

Mariani has published a Minoan seal on which a woman is sounding the shell of a Triton before the sacred horns of an altar. ${ }^{16}$ This seal, which was found in the Idaean cave, is also described and figured by A. J. Evans in his "Mycenaean Tree and Pillar Cult."17 "Here," he tells us, "a female votary is seen blowing a conch-shell or triton before an altar of the usual Mycenaean shape. Above the altar is seen a group of three trees, apparently cypresses, and immediately in front of them the 'horns of consecration.' To the right of the altar is a rayed symbol, to the left is apparently another altar base, with a conical

1 16id. p. 365, quoling A. Issel, "Revista Ligure di Scienze, Lettere ed Arti," Genova, I908, p. Ig.

12 Verland, Berlin. Gess. Anthrop. Ethnol. und Urges., I898, p. 485.

1 = Von Martens, op. cit., p. 485 , quoting Boswell, "Description of Corsica," I768, p. 183 .

$1+$ A. J. Evans, Journ. Hellenic Studies, xxi, Igor, p. 142.

15 See chapter I.

1 . L. Mariani, "Monumenti Anlici," vi., 1895, p. 178, f. 12.

if A. J. Evans, op. cil., p. I42, f. 25. 
excrescence, and behind the votary another tree. From this gem it appears that the conch-shell trumpet performed a ritual function in summoning the divinity."

At Palaikastro, and elsewhere, real Triton shells were found which had been used for purposes of cult. ${ }^{18}$

R. C. Bosanquet points out in his "Excavations at Palaikastro, I." that " the Triton-shell occurs as frequently in early deposits in Crete as it does in Mycenaean ornarnent-for the so-called Murex on the later pottery is only a degradation of the Triton."

A. J. Evans, in his account of the Knossos Excavations, $1903,{ }^{20}$ illustrates a Minoan clay seal impression, on which two Triton-shells are represented. He also records the discovery of an alabaster vase in the shape of a Tritonshell.1 Miniature clay models of the same conch-shell, with remains of a little terra-cotta Sanctuary, were also found in an early basement on the East side of the Palace. ${ }^{22}$

This Early Minoan rite spread in the Mediterranean region, for eighteen unbroken specimens of the same shell, Triton nodiferus, were found by Don Morelli in the Caverna delle Arene Candide, besides two hundred broken ones; and as they all had the apex removed it can be concluded that they were sounded like trumpets. ${ }^{23}$ Other Triton shells were found in the Caverna dei Balzi Rosso, in the Cave of Galuzzo and the Cave of Pollera."

is Inn. Bril. Sch. Athens, viii., (1901-2), pp. 32, 89, 244, 296, 305, 308; ix., (1902-3), pp. 275, 291, 312, and 335; x., (1903-4), pp. 197, and 202.

19 Ibid. viii., (I901-2), p. 296.

20 Ibid. ix., (1902-3), p. 56, f. 34 .

21 Tlid. ix., (1902-3), p. 36.

32 Ibid. viii., (I901-2), p. 32 .

${ }^{3}$ N. Morelli, "Resti organici rinvenuti nella Caverna delle Arene Candide," Genova, 1901, p. III.

24 Mosso, op. cit., 1910, p. 363. 
In another Ligurian cave, the Grotta di Bergeggi, a Murex trunculus pierced at the apex was found. ${ }^{25}$

In excavating the Minoan Sanctuary of Cannatello, near Girgenti, Mosso also found pieces of the Triton. ${ }^{26}$

In speaking of the Triton shells found in the neolithic caves of Liguria (see above), Mosso states that they are too numerous for them to have been used for signals, but "the fact that they are found associated with human bones gives reason to suppose that even in neolithic times these shells were sounded with a religious signification, as we see on the Minoan seals of Crete." ${ }^{27}$

Amongst the various species of shells used as trumpets, the chank-shell (Turbinella pyrum) is of special interest from its intimate connection with the religion of Hindus and Buddhists.

In a brief paper on "The Aztec Moon-cult and its relation to the Chank-cult of India," is I have already referred to the association of the chank with the Hindu god, Vishnu, and his many incarnations.

The whole subject of Hindu chank-cult has been recently treated in a most admirable manner by James Hornell in "The Sacred Chank of India," 29 and much of the following information is derived from his excellent work.

In Hindu temple worship, Hornell tells us, "the chank fulfils important service. The ordinary and sinistral forms are both employed whenever the temple possesses them. The former, is used in the menial duty of summoning the god's attention, announcing the commencement of the principal rites, as well as in calling the

25 T. E. Peet, "The Stone and Bronze Ages in Italy," 1909, p. 54.

20 Mosso, op. cit., I910, p. 364.

27 Ibid. p. 363 .

29 Manch. Memoirs (Lit. and Phil. Soc.), vol, 6o, pt. ii., 1916.

20 Madras Fisheries Publication, No. 7, 19I4. 
devout to worship; such are among the general explanations given for its employment, but some ethnologists hold that the innate and primitive significance of the use of the blowing chank in temple worship is to scare away hostile and evil-working spirits. This is a reasonable belief as there is little or no doubt that the chank was used originally as a horn or trumpet by tribes holding animistic beliefs prior to the development of the Brahman religion, which appears to have adopted the use of the chank in religious ceremonies together with many other rites from the devil-fearing tribes who gradually came into the fold of the new and higher religious belief." 30

In Bengal it is customary to keep blowing-chanks in the houses of the better class people for use in family worship, and during eclipses and earthquakes these shells are blown continuously till the eclipse or earthquake is over.:

Unlike the sinistral shells, which are usually mounted in handsomely decorated golden settings, the temple conchs are usually without any ornamentation, but the Udipi temple owns one very beautifully mounted in brass, and this is sounded whenever the god (Krishna) is carried in procession in the temple car. ${ }^{82}$

Chanks used as wind instruments are chosen of as large size as possible, and the only preparation they require is to have the apex knocked off.

A part from their actual use in temple ritual, chanktrumpets are employed in connection with harvest rites, marriage and funeral ceremonies, and in various other ways in different parts of India. It is an essential part of the professional paraphernalia used by certain castes of religious medicants. "The Dasari," Hornell tells us, "is

st Hornell, op. cil., pp. 134-5.

$\therefore 1$ Tbia. p. 135.

$\therefore$ Itrid. ple xvii, fig. I. 
often seen in North Arcot and the Southern Deccan, announcing his arrival in a village by blasts on the chank shell."

In Malabar, at the ceremony of the bringing in of the first fruits, the priest comes forth from the local temple, preceded by a man blowing a conch.

Similarly in Siam, conch-shell music is employed at religious ceremonies connected with the ploughing festival. The principal figure at these ceremonies is the Minister of Agriculture, who is bome in a palanquin to the field with an escort of priests blowing loud blasts on chank shells."

At weddings, among all Hindu non-Brahman castes in the districts of the south of India, the chank is blown by the barber (ambattan) particularly at or immediately after the tying of the tali or marriage badge round the bride's neck. In Bengal this custom of chank-blowing during weddings is even more general.

Though men are usually engaged to blow the chank at weddings, the women of the family or of the particular caste sometimes perform this duty.

A further interesting use of chank-trumpets is in connection with the rite of circumcision which survives among the Puramali nādu Kallans. This rite is carried out in a grove or plain outside the village, and the chank is blown at frequent intervals en route and throughout the ceremony. ${ }^{3+}$

Throughout the Tamil country all non-Brabman castes which observe Hindu rites have the chank sounded at death ceremonies. The chank sometimes has a place in the death ceremonies of castes which are not Hinduised, as the Cherumans of Malabar and Cochin. Here the chank-trumpet is used for devil-driving..$^{5 \hbar}$

3 i Hornell, op. cit., p. 144.

* loid. pp. r44-5.

35 Tbid. 1'p. 148-9. 
The chank is frequently employed upon native-owned plantations in South India and Ceylon to summon the workpeople to their duties.

In the Laccadive Islands it is used to call the people together in cases of emergency and public requirements:

In addition to the use of the chank, Turbinella pyrum, as a trumpet in India, T. Wilson, in his "Prehistoric Art," mentions other trumpets made from Cassis, or helmet shell (called Gomukha) and from Pterocera (called Barataka).

Speaking of the use of shell-trumpets in Ceylon, Lovell ${ }^{38}$ states, "According to the most ancient annals of the Cingalese, the chank-shell is sounded in one of the superior heavens of the demigods (similar to the conchblowing tritons of Grecian mythology) in honour of Buddha, as often as the latter wanders abroad on the earth." Hornell ${ }^{39}$ also says, "In the purer Buddhism of Ceylon the chank cult also finds place, and figures prominently among the musical instruments employed to lend eclat to the periodic procession (porahera) of the toothrelic at Kandy."

In Thibet, according to the writings of, travellers in that country, the call of the chank is amongst the most familiar sounds to be heard in the monasteries and temples of the Lamaistic faith. It is also the custom to sound the chank as the body of a deceased monk or nun is being conveyed from the place where death occurred. ${ }^{40}$

Chank-shells, especially sinistral specimens, are held in special veneration by the Chinese, and are kept in the Pagodas by the priests for use on special occasions.

\footnotetext{
$\therefore$ ibid. p. 172 .

"i Rept. U.S. Nat. M/us. for 1896 (1898), p. 555.

is Lovell, op. cit., p. 195.

s Hornell, op. cit., p. I37.

4" Ibid. pp. 137 and 149 .
} 
They are also blown to still the waves and ensure safe voyages. The Chinese, likewise, use a large shell, a species of Fusus, for their fog-horns. ${ }^{41}$

Both Huish" and Rein, ${ }^{43}$ in their works on Japan, mention the use of Triton-horns in that country. Rein tells us that shells of Triton tritonis (Japan, Hora-gai) "were formerly employed as signal horns and provided with a brass mouthpiece to replace the tips. According to Pinto, in blowing them, riot was indicated by one blast, fire by two blasts, robbery by three, treachery by "four, though they also played a part as signal horns in war, and were therefore also called Jin-gai, war mussel shells or camp snails. Their blowers were the Hora-fiu, or Horawo-fuku. Both these expressions for blowers of the Triton's horn have become in Japan the common designation for a person who is fond of boasting: "Ano hito wa hora wo fuku,' he blows the Triton's horn, i.e., he is bragging."

In the East Indian Archipelago and the Pacific Islands, we find many instances of the use of shells as trumpets.

In describing the wind instruments used by the tribes of Borneo, Shelford ${ }^{44}$ relates that some Brunei Malays recently informed him that a trumpet, made by merely knocking off the top whorl of the large helmet-shell Cassis tuberosum, was used by them for calling their buffaloes together ; their name for the trumpet was "buyong." $\mathrm{He}$ could hear of no other people in Borneo who employ a similar instrument.

41 A. If. Cooke, "Mollusks," Camb. Nat. Hist., I895, pp. Ior-2.

4" Huish, "Japan and its Art," 1893, pp. I 46-7.

4 J. J. Rein, "Japan," 1884, p. 207.

44 R. Shelford, "Illus. Cat. Ethnog. Coll. Sarawak Niseum: Yt. i, Musical Instruments." Joum, Straits Branch Roy. Asiatic Soc, No. 40. June, r904, p. 20. 
Von Martens refers to the use of shell-trumpets in the Philippine Islands, in the island of Halmaheira (or Gilolo ${ }^{45}$ and by the Alfurs of Ceram. ${ }^{40}$

A fine specimen of a trumpet made from a large Triton tritonis has recently been shown me by Professor S. J. Hickson. It was obtained by him in the Celebes, and is perforated on the side of one of the upper whorls. It was used by the boatman who carried round the mails, and may have originally come up from the south.

In Papua, or New Guinea, Cassis cormuta, Triton tritonis, and Ranella lampas, are used as trumpets, having a hole drilled as a mouthpiece in one of the upper whorls. ${ }^{47}$ In addition to the Triton, Moseley tells that a large conical Strombus, perforated at the apex, not on the side. as in Triton, is used by the natives of Humboldt Bay. Among the musical instruments used by the natives of the Admiralty Islands are conch-shells perforated on the side as usual. ${ }^{\text {ng }}$

The only instrument of the trumpet kind used by the Torres Straits Islanders is a giant Fusus [F.proboscidiferus, Lam. $\left.{ }^{50}\right]$, or occasionally a large Triton. The Fusus is universally employed, and, according to Haddon, ${ }^{51}$ the mouth-hole is always lateral. It was employed for conveying signals, but now at all events is most frequently blown when the natives are sailing, especially when going fast or racing.

is Zeits. fïr Ethnol., iv., 1872, p. 34, fide Schmeltz, "Schnecken und Muscheln im leben der vólker Indınesiens und Oceaniens," Leiden, I 894.

4 Verhand. der Berl. Anthro. Gess., 1898, p. 485.

${ }^{7}$ A. H. Cooke, op. cit., p. 99.

4" Moseley, "Notes by a Naturalist on H. MI.S. "Challenger'," 1892 , p. 378 . p. 411 .

4. Moseley, op. cit., p. 407, also Jour. Anthrop. Inst., 6, 1876-7,

„0 Probably Megalatracluzs anuanus (L).

\$1 "Anthrop. Exped, to Torres Straits," Cambridge, iv., 1912, p. 283, and fig. 248 . 
There is a Triton-trumpet in the British Museum from the mouth of the Fly River, British New Guinea, which, according to Chalmers, is used for calling to arms and for frightening away the evil spirits of sickness from the village. 5.

IV. H. R. Rivers, in his work on "The History of Melanesian Society" "s3 tells us that the conch-shell is one of the objects used in Banks Islands, in the ritual of initiation into the Suizere. On the initiation of a candidate into Kivatagiar, the conch-shell is blown five times, three long continuous blasts and two interrupted blasts. It is also used at initiation into the Tamate liwo In Torres Islands the conch is blown at ceremonies of kava drinking. ${ }^{5 t}$

From the same authority we learn that "the conchshell exists in two forms in Melanesia, one blown by means of a circular hole in the side, and the other blown at the end. The former is that used at the Sukwe and in most parts of Melanesia, and this form is also in general use in Polynesia. Its occurrence in Polynesia points to its ascription either to the kava-people or to the people who interred their dead in the sitting position, and there is reason to suppose that it was of especial importance in connection with the chiefs. It may also be noted that, in Malikolo, it is used at the funerals of chiefs. This connection with chiefs both in Polynesia and southern Melanesia, suggests that it was the kavapeople who brought with them the use of the conch, a conclusion in harmony with its prominence in the ritual of the Sukwe.

"In the Solomons, however, the conch is of especial importance in connection with head-hunting. It is used

s: Ifaddon, op. cit., p. 283 .

is 2 vols., Cambridge, rgI4.

¿4 Rivers, op. cit., i., pp. $64,98,186$. 
as a signal, especially in the ceremonies which accompany the return from a successful expedition, and this suggests either that it is an element of culture common to the kava- and betel-peoples, or that it was taken orer by the betel-people from the earlier inhabitant.s.

"The only nlace in Melanesia where we know of the existence of the conch-shell blown at the end is Efate [New Hebrides], and its association here with a special form of totemism suggests that it is connected with a special development of the kava-culture which has been responsible for the form of totemism found in this region."

In discussing the material culture of the inhabitants of the Bismarck Archipelago, Rivers further relates that "the conch made of the shell of the Triton is not only definitely present in New Britain and New Ireland, but it has that place in the ritual of the secret organisations which we should expect if it were introduced by the kara-people. IVhen the members of the Ingiet take one of their stone images from one place to another, its approach is heralded by the sound of the conch which warns all uninitiated persons to get out of the way. When an uninitiated person hears the conch, he says, 'Here comes an image from Nakanai,' thus associating the instrument with one of the more sacred images. Another indication of the importance of the conch in the Ingiet is that it may be shown to an initiate in place of a stone image if one of these is not available, thus suggesting that the conch may once have formed one of the mysteries of the society, comparable with the a'erewere or meretang of the Banks Islands or the bullroarer of the Matambalex and Rukiuk:"

s.) Thid, ii., P. 459.

$\therefore$ Thia. ii, , P. 535 . 
Zembsch, in his "Katalog No. I verzeichniss einer ethnographischen Sammlung aus der Siidsee," gives a photo of a clay figure of a god from Malikolo with a Triton-trumpet tied to each hand. The trumpets are perforated on the side of the spire.

In the Solomon Islands, Guppy ${ }^{58}$ teils us that the shelltrumpets are made of large examples of both Triton and Cassis, with a hole pierced on the side of the spire.

In the island of Tanna, in the New Hebrides, shelltrumpets are blown as signals to the disease-makers, or sorcerers, to entreat them to stop plaguing their victims. "These disease-makers collected any nalak, or rubbish, that had belonged to anyone, such as the skin of a banana he had eaten, wrapped it in a leaf like a cigar, and burned it slowly at one end. As it burnt, the owner's illness increased; and if it was burnt to the end, he died ; therefore, as soon as a man fell ill, feeling sure that some sorcerer was burning his rubbish, shell-trumpets, which can be heard for miles, are blown as a signal for the sorcerers to stop, and wait for the presents which should be sent in the morning. When a disease-maker fell ill himself, he too believed that some one was burning his rubbish, and had his shells blown for mercy."

Hedley, in his "Ethnology of Funafuti," that the Ellice Islanders are called together to a trial or other public ceremony by the blowing of a shell trumpet made from the large Cassis cormuta.

The conch-shell also ranges among the musical instru-

si Ethnographische Alsteilung der Buchhandlung und Druckerei vormalı, E. J. Brill, Leiden, 1897, pl. iii.

58 Guppy, "The Solomon Islands, and their nalives," I887, p. 143.

ù Lovell, op. cit., 1884, p. I95, quoting Turner's "Polynesia," and Tilylor's "History of Mankind," p. r2S. See also G. Turner" "Samoa," etc., I 884 , PP. 320-2 I.

is o .Hem. Aust. Mus., iii., pt. 4, I897, p. 299. 
ments of the Fijians, and of the Maories of New Zealand..$^{61}$

When Captain IVilson risited Tongataboo, in the Friendly Islands, in 179\%, four large conch-shells were found on the floor of a large house sacred to the god of Bretane. These were used to alarm the country in times of danger. In these islands conch-shells were also blown at the interment of chiefs. ${ }^{\text {in }}$

Shell-trumpets, made from Triton tritonis and other large shells, enter largely into the religious ceremonies of the Samoans.

In his description of the religion of these people, Turner" relates that "in their temples they had generally something for the eye to rest upon with superstitious reveration. In one might be seen a conch shell, suspended from the roof in a basket made of cinnet network; and this the god was supposed to blow when he wished the people to rise to war."

The Samoans have a host of imaginary deities, and these gods are supposed to be incarnate in some visible object, the particular thing in which the god appears being an object of veneration.

Faamalu (shade), one of the village gods, was represented by a trumpet-shell, and at the annual worship of this god all the people met in the place of public gatherings with heaps of cooked food. Another local god was called Tapaai (Beckoning) and was a war god of a family on Tutuila. He was supposed to be present in a trumpetshell. When the people were about to go to war the shell was blown by the priest, and all listened. If it blew rough

61 Lubbock, "Prehistoric Times," 1865, pp. 358 and 369 . Captain Cook also mentions the "Triton's trumpet" as one of the sonorous instruments of the New Zealander:

"2 G. A. Cooke, "System of Universal Geograplyy," London, i., 1 Sor, pp. 77 and 97.

* 8 (i, Turner, "Samoa, etc.," London, 1884, p. 19. 
and hollow it was a bad sign; but if clear and euphonic all were cheered, and went off joyfully under the good omen. In the island of Savaii a village god named Titi usi (Glittering leaf girdle) was worshipped at the new moon, and after prayer and feasting a man went about blowing a shell-trumpet as a sign that the ceremonies were over, and that the usual routine of village and family life might be resumed. ${ }^{6.4}$ A further use of shell-trumpets noted by Tumer in Samoa was to herald the approach of some important personage. A chief of importance must have one, or perhaps two, large shells in his canoe, to answer the purpose of trumpets, to blow now and then as the canoe passed along. ${ }^{65}$

In Manahiki, or Humphrey's Island, Turner states that when the constellation Pleiades was seen there was unusual joy expressed by singing, dancing, and blowing shell-trumpets. ${ }^{66}$

In the Society Is. large shells of Triton tritonis, L. are used as trumpets, and these are blown when processions walk to the temple, or warriors march to battle, at the inauguration of the king, during the worship at the temple, or when a tabu, or restriction is imposed in the name of the gods. Ellisis tells us that large shells were selected for this purpose, and these were sometimes above a foot in length, and seven or eight inches in diameter at the mouth. In order to facilitate the blowing of the trumpet, a perforation, about an inch in diameter, was made near the apex of the shell. Into this a bamboo cane, some three feet in length, was inserted, and secured to the shell with fine braid. The outside of the aperture was rendered air-tight by a resinous gum from the bread-

it + Turner, op. cit., pp. 27, 54,60.

65 llid. pp. 165-6.

is Ibid. p. 279.

oi "Polynesian Researches," i., 1836, pP. 196-7. 
fruit tree. These trumpets are also used by the herald, and on board the native fleets.

Captain Cook also speaks of the natives of Toobouai Island blowing large conch-shells in a long tone without any variation; but what it portended he could not ascertain.

Hutchinson ${ }^{\text {ig }}$ gives a casual reference to the shelltrumpets of the Marquesas Islands, saying that they differ from that known as "Bosina" in Peru (see below).

In Micronesia, shell-trumpets are recorded as in use at Ponape (Ascension I3.), Caroline Islands, and in the Marshall Archipelago." Of their use in the Pelew Islands, Captain Wilson telis us $\mathrm{s}^{\bar{i}}$ that in 1783 , as a preliminary to an attack on a neighbouring enemy, the king, Abba Thulle, ordered the conch to be sounded as a signal for forming the line of battle. Captain King also refers to the blowing of the conch as a signal of defiance and warning in the Sandwich Islands."

In the New World we have several instances of the use of shells as trumpets. A species of Triton was used formerly by the Indians of South America as a trumpet, and a specimen was dug up at Canete, in Peru. The shell was called "Bosina," on account of the sound produced by blowing into it resembling the roar of a bull, and it was used to announce the approach of any great man into a town. It was ornamented with tassels of human hair, and a leather strap of exquisite workmanship.

os G. A. Cooke, op. cit., i., p. 65.

69 Joum. Anthrop. Tust., iv., I874, p. I3.

:0 O. Finsch, "Ethnologische Erfahrungen und Belegstücke aus der Südsee," Annal. des $K$. K. nathist. Hofmusezuns, Wien, 1888-93, fude Schmeltz, op. cit.

roa "An account of the Pelew Islands," London, 1789, P. I50.

$\because 1$ G. A. Cooke, op. cit., i., pp. 306 and 353 .

72 Lovell, op.cit., p. I96, quoting Hutchinson's "Two Years in Peru," vol. i., p. I34. 
An interesting survival of this practise in Central A merica is recorded by Theobert Maler in his "Researches in the Central Portion of the Usumatsintla Valley." On p. 33 of his paper he relates how his arrival at the Indian settlements at Pethá was greeted by the blowing of conchshell trumpets made from Strombus gigas.

According to Pinart, ${ }^{7 \neq}$ the musical instruments of the present natives (Guaymis) of the Chiriquian region of Panama are limited chiefly to the bone-flute and the marine conch-shell. He describes one of their ceremonies, the balza, in which the conch-shell plays an important role. When a village has decided to give a balzaria and the date has been fixed upon, notice is given to other villages inviting the inhabitants to attend. Everyone is invited, men and women, young and old. According to the distance away, each family group sets out in time to arrive at the place of meeting two days before the commencement of the ceremonies. During the journey, the invited guests blow from time to time on large conchshells in order to make known to all persons living near the line of route their passage and the purpose of their journey.

Pinart believes the Guaymis to be the descendants of the race that constructed the ancient huacals from which so many Chiriquian antiquities have come. This ancient race has left behind them numerous examples of wind-instruments of clay, modelled in the form of animals and birds. One of these figurines serving as a whistle represents a mythical form holding something resembling a fish or conch-shell a little distance from the mouth. ${ }^{75}$

73 Memoirs Peabody Museum, ii., no. i., Igor.

74 Alphonse Pinart, "Les Indiens de l'Etat de Panama," Rev. d"ethnog., vi., 1887, Pp. 33, II7, (quoted by Mac Curdy, "A Study of Chiriquian Antiquities," Memoirs Conn. Acad. Arts and Sciences, iii., I9I I, pp. 169-I70).

${ }_{75}$ Mac Curdy, op. cit., p. I85, fig. 315. 
An analogous idea is expressed in a beautiful Chiriquian gold casting of two human figures with elbows touching and holding to their mouths something that resembles a conch-shell or a fish.i"

Robert Brown relates that the descendants of the Incas, in Peru, under the rule of Francesco de Toledo, in I 568, held periodical festivals in memory of their beloved sovereigns, when plays were enacted and mournful music produced from the national instruments, drums, trumpets, clarions, and putatus, or sea shells."

According to von Martens, ${ }^{7 s}$ the Jesuit priest Arriaga, at the beginning of the 1, th century, also describes the use of shell-trumpets in Peru, and in the Bolivar collection of the Berlin Ethnographical Museum there is a preColumbian trumpet made of Strombus galeatus.

The Portuguese writer, Suarez de Sousa, in I 589 , and Marcgrave, about 1640 , report on the use of trumpets in Brazil, made probably of Strombus goliath."

In a paper on the ruins in Casa Grande, in Southern Arizona, ${ }^{80} \mathrm{~J}$. IV. Fewkes states: "Among the more numerous marine shells which were found in Compound $B$ of the Casa Grande group of ruins are many large conchs, the points of the spires of nearly all of which were ground off and perforated as if for trumpets. Judging from known ceremonies of the Hopi, it is highly probable that these trumpets were used in dramatic celebrations in which effigies of the great serpent were introduced, the priest using the instruments to imitate the supposed roar of this animal. More than a dozen complete specimens, and many fragments of conch shells that may have been parts

\footnotetext{
is Itirl. pp. 185, 209, and pl. xlix., fig. A.

$\because ;$ "Races of Mankind," i., N.D., p. $3^{\text {I6. }}$

is Von Martens, op. cil., p. 485.

$\because 9$ 7bict. p. 485 .

“" 2 Sth Ann. Rept. Bureau of Amer. Elhniligy'. 19г2, pp. 144-5.
} 
of trumpets, were found in the course of the excavations at Casa Grande, the greater number being obtained on the west side of Compound B. All these shells came originally from the Pacific coast."

G. H. Pepper, in his paper on "The Exploration of a burial-room in Pueblo Bonito, New Mexico,"81 also records the discovery of a shell trumpet, made from Strombus galeatus. It had evidently been cracked in use and showed signs of repair. Associated with it was a human skeleton ; also Haliotis shells, and 26 perfect shell bracelets and I 5 fragments. The bracelets, he adds, averaged $8.5 \mathrm{c} / \mathrm{m}$. in diameter, and are probably made from Pectunculus shells. In other parts of the room were further shell bracelets, pendants, and beads, of Olivella shells; also ornaments of turquoise and shell mosaic. ${ }^{8.2}$

Carl Lumholtz, in an interesting paper on "Symbolism of the Huichol Indians," "gines us details of the use of a species of Murex as a trumpet at ceremonies and feasts. After describing various other objects used at the feast of tamales de mais crudo, he states (p. I85): "At the same feast, but only on the eastern side of the river, seashells are employed as a kind of musical instrument. When the heap of tamales is dedicated to the gods by the shamans, some of the people are appointed to blow into such shells five times in the daytime and five times at night. This is done as a signal to all the gods. After the feast the shells are carried to Mesa del Nayarit, where they remain through the wet season, to be afterwards brought back again for the next feast of the same kind. They are kept in Mesa del Nayarit in a god-house. According to tradition, the Chichimecas brought them first from that part of the coast where San Blas is to-day."

s I Putnam Anniversary Volume 1909, p. 226.

\$2 This mosaic recalls the beautifal Haliotis inlay of Japanese artis 1 .

s 3 Mem. Anter. Mus. Nat.,Hist., iii. ; Anthropology, ii., 1900. 
Lumholtz was unable to procure any shell that had actually been used at the feast, but he found one in the god-house of the Sun (Tayau') in Têalia'ta, which, according to his informants, was smaller than those used. The species is Murex (Phyllonotus) radix Gmelin, from the South Pacific Ocean, west coast of America. In Huichol it is called Ku'ra. Much difficulty was experienced in buying the specimen; the man who had deposited it, and who was one of Lumholtz' party, at first absolutely refused to part with it. Although left some years ago, it still remained to him a valuable prayer for life. Through the acquirement of this specimen, which was the only one seen in the god-houses, Lumholtz learned of the interesting custom of blowing into shells just related. The natural markings on this shell symbolize to the Huichols grains of corn and water.

Probably the most remarkable occurrence of the use of shell-trumpets in the New World is afforded by Mexico. Von Martens ${ }^{84}$ refers to the finding, by Seler, of prehistoric trumpets made from Fasciolaria gigas ${ }^{85}$ and Turbinella scolymus from the Caribbean Sea, and Fasciolaria princeps from the Pacific Ocean, in several parts of Mexico.

From ancient Mexican manuscripts we learn that conch-shell trumpets entered largely into the religious ceremonial of the Aztecs.

In Seler's description of Codex Vaticanus, No. 3,773, reference is made to the blowing of shell-horns in the temples at midnight, as a signal for the priests to arise and mortify themselves, to sing, and then go in procession to the bath. ${ }^{86}$

$\$ 4$ Von Martens, op. cit., p. 485 .

ss Probably $F$. gigantea is meant here.

86 Edward Seler, "Codex Vaticanus, No. 3,773 (Codex Vaticanus B), an old Mexican pictorial manuscript in the Vatican Library," Berlin and London, I902-3, English translation by A. H. Keane. 
In the same work and elsewhere moçauani, the Fasting Man, Ruler of the Nineteenth Day-count quiauitl, "Rain," is figured blowing a conch-shell and associated with Tonatiuh, the Sun God. ${ }^{\text {it }}$

According to Sahagun and other authorities the ancient Mexicans held a special festival once or twice a year, on the day Nahui Ollin, in honor of Tersatlipoca Lord of the Night, etc. At noon on each of the four days preceding this festival, conch-shells were blown by the priests, whereupon everybody, great and small, old and young, gashed their tongues and ears, and presented the the blood to the Sun-"doubtless," says Seler, "with the intention thereby to give it strength to resume its course in the usual way." " ${ }^{8}$ The linking together of ear-piercing and the use of shell-trumpets in this ceremony is of considerable significance.

It is important to note, also, the remarkable resemblance to the Minoan use of the conch-shell trumpet in summoning the divinity. (See p. 33). An even more striking parallel is found in the Babar Is. (Malay Archipelago), where the sun-god is called down to accept offerings by means of a L'riton-shell. ${ }^{89}$.

In the Mexican pictorial manuscript-Codex Magliabecchiano-in the Florentine Biblioteca Nazionale is an illustration showing Pochipilli, called by Seler the God of Flowers and Food Supplies, being carried in procession preceded by a priest blowing a conch-shell trumpet. ${ }^{90}$ (See Fig. 6 on plate facing p. 52.)

s7 Seler, op. cit, p. 185 , fig. 393 , and sheets 28 and 94 . The shell is probably Fasciolaria gigantea.

ss Seler, op. cit., p. 186. Zelia Nuttall, "A Penitential Rite of the Ancient Mexicans." Arch. E Ethnol. Pupers of Peabody Mus., vol. i., No. 7, I904, p. 4.

39 I am indebted to Mr. W. J. Perry for this information.

90 Seler, op. cit., p. 162, fig. 363. The shell looks like a reversed Cassis cornuta. This species is common to the West Indies, Pacific Islands, etc., and is used as a trumpet in Papua and other Pacific Islands. 
Further illustrations of the use of the shell-trumpet by the Aztecs are seen in Codex Borgia I 4 , where Tepeyollotli, the I- Heart of the Mlountains, God of the Caves, is figured blowing the shell-horn, and in Codex Taticanus, No. 3.773, sheet 22, where the same god wears the shell-horn as a breast ornament and a second horn lies before him at the threshold of the temple."!

In the Codex Vaticanus and elsewhere the Mexican Moon God, Teciztecatl, is represented in association with a large conch-shell as its symbol. This appears either on the brow of the god or at the back of the neck. As the emblem of the moon the shell also appears with the figure of a man holding in his hand a blood-stained agaveleaf spike, or merely a hand holding a bone dagger and agave-leaf spike, emerging from the mouth--the God in the shell-which might have reference to the waters being pent up, or possibly to different phases of the moon. The Rain God, Thaloc; is thus seen at the mouth of the shell, or emerging from it, holding lightning in both hands. (See Figs. $2-5$ on plate facing.)

The snail-shell was also brought into association by the Aztecs with conception, pregnancy and birth; for, as the interpreter of the Codex Telleriano-Remensis says: "asi como sale del hueso el caracol, asi sale el hombre del vientre de su madre."

The Moon God is thought by Seler to bear this name "perhaps on the one hand because he has his phases, at times withdrawing half or altogether into his shell.". But on the other hand-and this is what the interpreters lay stress upon-it seems as if he owed this name to the relation in which the moon stands towards women, to the influence which it exercises on the bodies of women. In

: I Seler, op. rit, p. 103, figs. 295. and p. 105, sheet 22. IIere the shell is like that of the Fasting-man, i.e., Furciolu ia grisanted. 


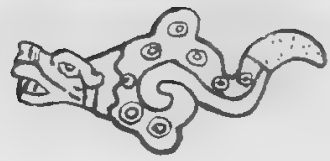

I

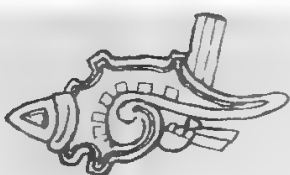

2
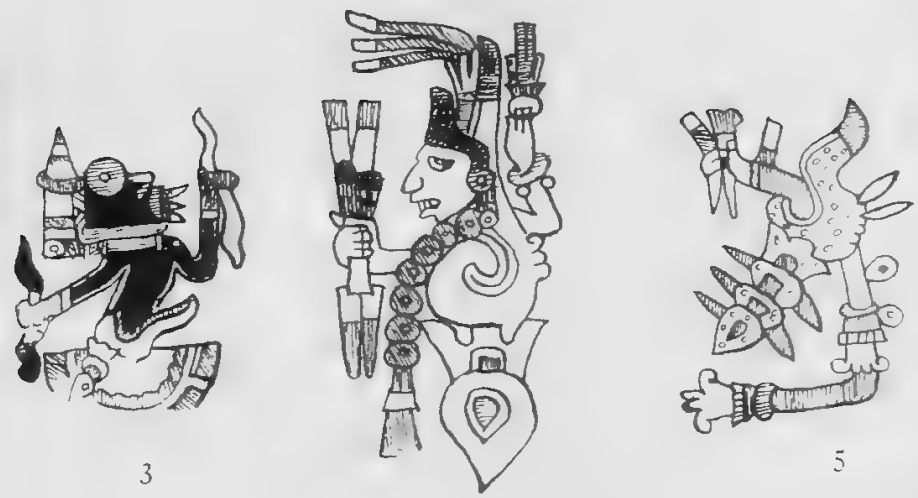

4

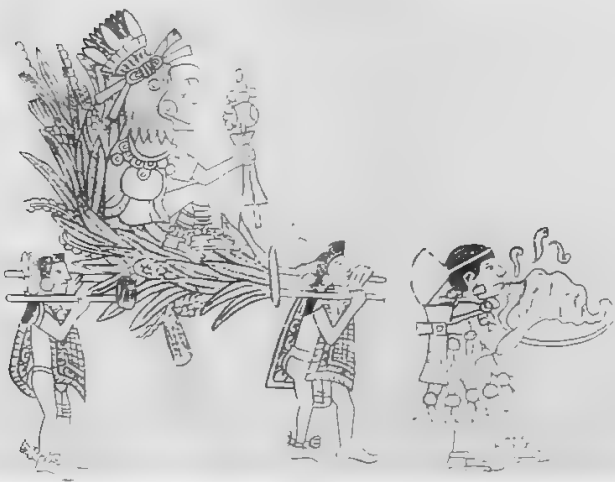

6

(I) Conch-shell with apex replaced by snake's head. Codex Vaticanus B66.

(2) The God shut in the House. Codex Vaticanus No. 3773.

(3) The Rain God shut in the Shell. Codex Bologna 8.

(4) The God concealed in the Shell. Codex Borgia 8.

(5) The God enclosed in the Shell. Codex Bologna 4.

(6) Aztec priest blowing the Shell-trumpet. Codex Magliabecchiano xiii., 3, f. 35 . 
, 
fact the bond of connexion between the moon and these shells is the ancient association of both with women which grew up in the Old World somewhere in the region of the Red Sea.

The remarkable identity in the Hindu and Mexican use of shell-trumpets in temple worship and harvest rites, and the association of the conch-shell with the God of the Moon, has been pointed out in a previous article. ${ }^{69}$

The Chank (see Frontispiece, Fig: 5) is one of the two important symbols associated by Hindus with Vishmu and his many avatars or incarnations. Siva, also, is sometimes represented holding the chank. Such an association is of peculiar interest when one considers the worship of the chank in the daily liturgy of the Brahmans. Taking the shell in his hand, the Brahman recites the following prayer :-

"At the mouth of this shell is the God of the Moon, on its sides is Varuna, on its back Prajāpati, and on its apex, the Ganges, the Sarasvati, and all the other sacred rivers of the three worlds in which they make ablutions according to the command of Vāsudeva. ${ }^{93}$ In this chank is the chief of the Brahmans (Brahmendra or Brahmanaspati). This is why we worship the sacred chank. Glory to thee, sacred shell, blessed by all the gods, born in the sea, and formerly held by Vishnu in his hand. IVe adore the sacred chaink and meditate upon it. May we be filled with joy!

"I offer (to the chank) everything needful for worship-perfumes, rice and flowers."

In India the moon is believed to preside over the growth of crops and produce, and in certain places, as

o2 Jackson, "The Azlec Moon-cult and its relation to the Chank-cult of India." Manch. Mtmoirs (Lit. and Phil. Soc.), vol. 60, pt. ii., tg16.

a One of the names of Krishna.

st Hornell, "The Sacred Chank of India," I9I4. 
already stated in previous pages, chank-trumpets are employed in connection with harvest rites.

In the above prajer, and in the harvest rites, are thus embodied the very elements which make up the moon-cult of the Aztecs. Associated with the chank we have ( $a$ ), the God of the Moon, and ( $b$ ), Varuna, the Hindu god of the waters and of the west quarter, who is worshipped as one of the guardian deities of the earth, and in times of drought and famine. $\mathrm{He}$ is represented in paintings as a white man seated on Makara, a mythical crocodile. This god recalls Tlaloc, the Mexican Rain God, who is sometimes associated with the crocodile, and, as previously mentioned, is depicted as emerging from the conch-shell. (c), Prajāpati, "the father of all creatures," a personification of the sun, is emblematical of creation and birth. The snail or conch-shell, as we have seen, was also associated with conception and birth by the Mexicans.

The offerings made to the chank of the fruits of the earth; the harvest rites accompanied by conch-shell music; and the use of shell-trumpets in Hindu temple worship, have their counterparts in Mexican manuscripts in the figure of the God of Flowers and Food Supplies being carried in procession preceded by a priest blowing a conch-shell trumpet, and in references to the blowing of conchs in the temples at midnight as a signal for the priests to arise and mortify themselves, to sing, and then to go in procession to the bath.

In India both the ordinary and the rare and highly prized sinistral forms of the chank are employed in temple-worship, and it is not a little curious to find that in the Mexican pictures both forms are also shown. It is quite possible that here, as in India, the sinistral form may have had a special significance. 
It is altogether inconceivable that people so far apart as India and Mexico could have independently associated the conch-shell with the moon and adopted it as the symbol of their Moon God, in addition to using it as a trumpet, and one may justly conclude that we have here definite proof of the transmission of an element of culture from the Old to the New World.

If any further evidence is needed regarding the similarity in the moon-cult of these two people, it is provided by the fact that the ancient Mexicans, like the Hindus, regarded what we call the "Man in the Moon" as a rabbit, and explained the present fainter brightness of the moon by the myth that the gods flung a rabbit in the face of the moon, which originally shone as brilliantly as the sun. Strangely enough Dr. Seler points out this fact in his description of the Codex Vaticanus, but makes no further comment.

In Aztec picture-writings the moon is figured-usually as a nasal crescent of bone with a rabbit seated in a watery field-beside the so-called "Goddess of Filth"-the old Huaxtec Earth Goddess.

The "God in the Shell" idea, i.e., the curious belief in the presence of gods, spirits, or human beings, indwelling in shells is remarkable for its wide-spread occurrence. Förstemann, in his discussion of the "Tortoise and Snail in Maya Literature" "ventures to connect the snail with the winter solstice; the tortoise with the summer solstice. In the Dresden Maya manuscript, he informs us "the sea snail appears very curiously in page 376 . Here it lies in the water and appears to be in the act of giving birth to a tiny person (female?)." This seems to bear some relation to the ancient myth that Venus was born of the froth of the sea, within a shell, which transported her to Cyprus.

95 Burean of American Ethnology, Bull. 28, 1904, pp. 423-430. 
The Dresden Codex also shows the snail associated with the gods of birth, and of the moon (the god $\mathrm{D}$, of Schellas), of death, and of the sun, and in the month Mol, the eighth of the Maya year. It is widely acknowledged that the snail is the symbol of birth among the Central American people. ${ }^{96}$

According to Spinden," "the snail, so-called, is represented in combination with the human form much more often than the tortoise, and occurs not only on the buildings at Chitchen Itza . . but also in the codices and on objects of minor art such as pottery. The word "snail" is commonly used, but there are no means of telling whether the shell represented belongs to the snail or to some other mollusc. According to Tozzer and Allen the shell is probably that of Fasciolarin griganton, which is the largest known American shell and is found along the coast of Iucatan." This writer gives a series of representations of anthropomorphic figures, consisting of the human form combined with a shell, taken both from Aztec and Naya manuscripts. One of these, from the Peresianus Codex, shows a personage called by Schellas, God N, the God of the End of the Iear. Another authority, Dr. Seler, however, refers to him as the Old Bald-headed God, and suggests that he governed the moon. "He is probably related," says Spinden, "to God D, the principal Romannosed God. Usually, but not always, this God $\mathrm{N}$ wears a large shell from which the upper part of his body seems to emerge." It will be recalled that Teccistecatl, the Moon God of the Mexicans, is represented in the Codex Vaticanus No. 3,773, with a conch-shell on his brow; in the Codex Telleriano Remensis the shell appears at the back

9 s Förstemann, op. cit., Pp. 428-429.

97 "A Study of Maya Art," Mem. Peabody Museum of Atmer. Arituol. and Ethut., vol. vi., I913, p. 83. 
of the neck of the same god. Dieseldorff excavated at Chamá, Guatemala, several pieces of pottery with painted or incised representations of the Shell God. ${ }^{98}$ At Chitchen Itza, sculptured figures on buildings often have a shell attached to the body. Spinden" informs us that "in the lower right hand corner of the Foliated Cross at palenque is a shell in which is partially concealed the Long-nosed God. From the hands of this god issues a plant amid the leaves of which is a face resembling that of the Maize God. The shell in this connection probably appears as an indication of water" (see Fig. 2 on plate facing p. 58). Tlaloc, the Mexican Rain God, is similarly represented in Aztec codices, possibly signifying the drying up of the waters.

Two interesting figures of the association of the Moon God with the conch-shell are given in the Dresden Maya manuscript. ${ }^{100}$ In one (Fig. I, plate facing p. 58), the Roman-nosed God ( $=\mathrm{D}$ of Schellas) emerges from the shell under the water, whilst the Long-nosed God (=B of Schellas), identified by some with Clurc, the Rain God of the four quarters and the equivalent of Tlaloc of the Mexicans, is seen on the surface of the water holding a fish in one hand. This figure seems to show the close association of these two Maya gods. In other representations we find these gods merging the one into the other; and in one case Cluac, the Rain God, appears as the Moon God. Dr. Elliot Smith claims $^{101}$ that the Maya Chac is the American form of the

o* Tor figures see Spinden, op. cit., p. 84, f. Io8b; Seler, Zeit. fiir Ethnol., 42, p. 284, f. 1000.

s:s Spinden, opt. cit., p. 84 .

100 See Spinden, op. cit., p. 83, f. 108 c \& d; Förstemann, of. cit., p. 428 , f. I05a; Seler, Z. furr E., 42, p. 284 , f. 998 and $999 \mathrm{~b}$.

101 "Precolumbian Representations of the Elephant in America," Natuse, December 16, I9I5. 
Vedic Indra. He tells me that in the later Vedas Indra took over a number of the attributes which originally were associated with Soma, who in addition to being a drinkgod, i.e., an Asiatic Dionysos, was also a moon-god. Indra also assumed many of the characters of l'aruna; and it affords further confirmation of the identity of Indra with Chac or Tlaloc to find the same elements of confusion also in America. Each divinity is presented in Maya codices in numerous phases closely associated with the serpent, the tortoise, or the conch-shell, recalling forcibly the several incarnations of the popular Hindu deity, Vishnu. The fundamental conception is, in fact, ty pically Brahmanical. In order to make this quite clear let us turn to the points of similitude which we find in India. The avataras ["descents"] of Vishmu are ten in number, the first of which, Matsya, or fish, is said to have reference to the universal deluge from the waters of which $I^{r}$ islınu in this form recovered the Vedas, or Sacred writings of the Hindus. ${ }^{102}$ In a work published in 1731 , Picart ${ }^{108}$ gives a picture and the following interesting and quaint account of I'ishnu's exploits: "He first assumed the shape of a fish, in order to search for the T'edam at the bottom of the sea, whither it had been carried by an evil Genius, who had forc'd it away from the Deutas. Wistnou at the urgent request of the Diztas, plung'd into the sea, kill'd this evil Genius, and return'd with the Vedam, which he found in a shell. The figure [see Fig. I, plate facing p. 62] represents IV istnou coming out of the fish, whose form he had assum'd; his two right hands hold the $V \varepsilon d u m$ open, and a ring; his two left, a sabre, and the shell in which the Vedam was

102 Birdwood, "The Industrial Arts of India," Part i, p. 57 (South Kensington Dhuseum Handbook).

103 "Religious Ceremonies and Customs of the several Nations of the known World," vol. iii., r73I, P. 4I5, pl. Ior. 

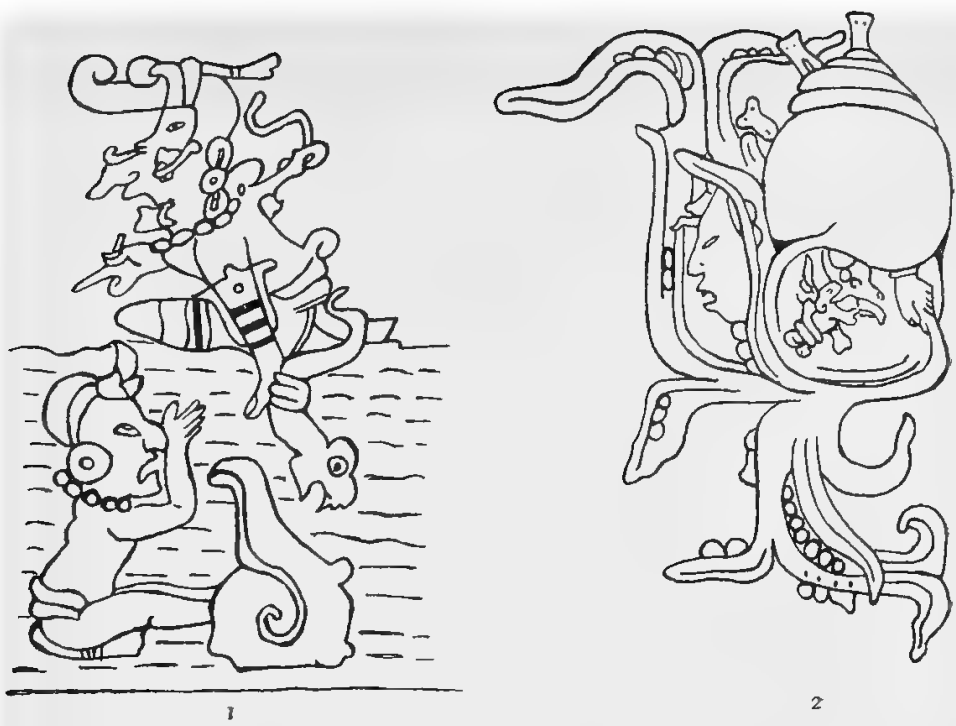

2

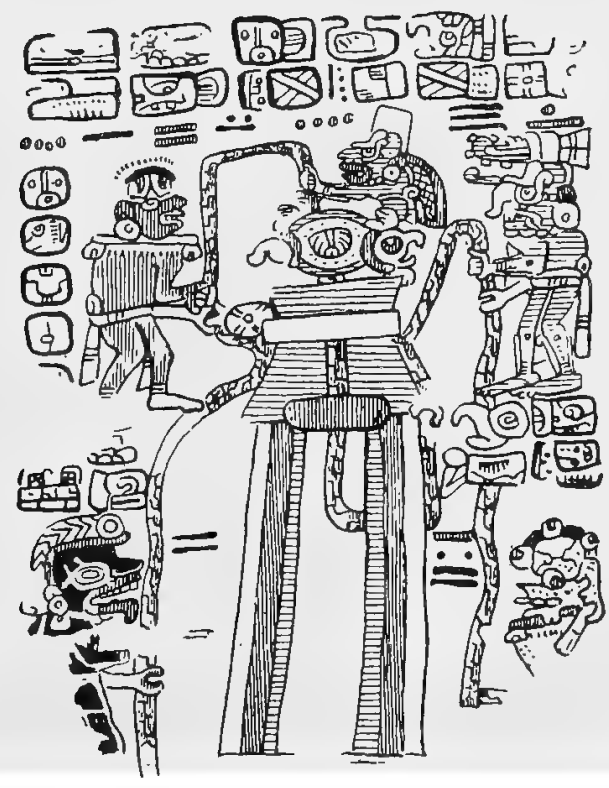

3

Maya Sculpture and Picture-Writings.

(I) Conch-shell associated with Maya deities. Dresden MS 38b. (after Förstemann). (2) The God in the Shell. Tablet of the Foliated Cross at Palenque (after Spinden). (3) The Tortoise associated with Maya deities. Codex Corles Igb (after Seler). 

inclos'd; the monster is seen headless at his feet." Other accounts relate how Vishun, as Krishna (the eighth incarnation), "went down to the infernal regions, and brought back his six brothers whom Kansa [Raja of the Bhojas] had killed; and then he killed the demon Panchajana who lived in the chank shell, which he ever afterward used as a war trumpet." "os

In the "Bhagavad-Gítá," a Sanskrit philosophical pocm, we find Krishun's conch-shell trumpet called Panchajanya. ${ }^{105}$

An embossed design on the cover of Thomson's translation of the "Bhagavad-Gítá, illustrates one of the many Hindu conceptions of the fish incarnation of Vishmu, and shows the demon in the mouth of the shell; one of Vis/mu's hands is empty. In the illustration taken from Picart lishmu holds the chank in one of his hands. The cutting off of the apex of the shell, represented in this picturc by the demon's head, ${ }^{100}$ illustrates the method adopted in India for the manufacture of chankshell trumpets, which are always blown from the end.

The second avatar of Vishnu is the Kurmury, or tortoise. The gods, aware of their mortality, desired to discover some elixir which would make them immortal. To this end, Mount Meru was cast into the sea, Vishnu then plunged in, in the form of a tortoise, and supported on his back the mountain, round which the Naga or snake, $V$ ísuki, was twisted, so that the gods seizing his head, and the demons his tail, twirled the mountain till they had

104 Birdwoud, op. cit', pp. 7ł-5.

I0 "The Bhagavad-Gítá," translated by J. Cocklurn Thomson, IJertford, 1855 .

i 0 " In the Corlex Vaticanus, B. 66, the conch-shell is shown with the head of a snake for its apex-probally a variant of the same idea (see Fig. $I$, plate facing $\mathrm{p} .5^{2}$ ). 
churned the occan, ${ }^{1 "-}$ out of which was then produced the amritit, or water of life, and thirteen other gems. ${ }^{100}$ A variant of this account is given by Picart (op.cit., p. 4I5) who says that "using this serpent as a cable, they lifted up the mountain, and afterwards let it fall again, till they at last forc'd this haughty element [the sea] to restore all the wealth which had made it so proud." (See Fig: 2, plate facing p. 62).

Turning to the Dresden Maya manuscript we find, on page 37 a, a representation of the Old Bald-headed God (the Noon God) with the shell of the tortoise on his back ${ }^{109}$-an incarnation, in fact, of the god as a tortoise. But an even more striking picture is seen on p. Igb of the Codex Cortes. The illustration there given ${ }^{110}$ shows the tortoise on the top of a churn-like structure about which is coiled an object resembling a snake (Seler calls it a rope, but it appears to possess scales). On the left side of the central object are two dark coloured gods or demons holding on to the snake; on the right side, similarly employed, stands the Long-nosed God (= Chac, the Rain God), and another indefinite personage. Apparently seated on the back of the tortoise is another God (? Roman-nosed God) who also holds the snake. In describing this picture, Seler calls attention to the tortoise being marked with a hieroglyphic sign which occurs in the winal-name your and yar-kin, and which perhaps signifies "tree" or "wood." He further states: "It [the

${ }_{107}$ C. F. Oldham, "The Sun and the Serpent," London, I905, p. 58, regards "the churning of the ocean," alluded to in the "Mahabharata" as "an allegorical description of sea.borne commerce in its early days" (quoted by Ir. G. Flliot Smith, "The Migrations of Early Culture," Manchester, J.9 I5, p. 82).

10s Birdwood, op. cit., p. 57 ; Thomson, "Bhagavad-Gitá," p. I47.

109 Seler, Ziti. fïl Elhnol., 42, p. 51, f. 738.

21" Seler, Z. für E., 42, p. 48, f. 724. 
tortoise] figures there in the centre of a remarkable ceremony in which a number of gods pull a rope up and down to which is fastened the element Kin 'Sun."' (See Fig. 3, plate facing p. 58).

No one who carefully and conscientiously examines this remarkable picture can have any doubt that it represents the tortoise incarnation of the Hindu god Vishmu.

In these and other similar designs in the Maya manuscripts we cannot fail to recognise the results of an infiltration into America of somewhat confused ideas concerning Vis/mur, the popular Hindu god, who, as already pointed out, is intimately associated with the conch-shell trumpet (the sacred chank) and the tortoise, among other objects. It is inconceivable that ideas of so arbitrary a nature could have arisen independently in India and Central America. That the fundamental conception of the Maya pictures is the same as the Indian cannot be denied. They were certainly inspired by ideas brought from India, which again were probably founded upon elements of culture from Western Asia and the Mediterranean. As is wellknown, one of the Babylonian myths relates how the people of Ancient Chaldra received their early knowledge of sciences and arts of all kinds from the fish-god, Ea or Oannes, who rose from out of the Erythræan Sea. But it is to the island of Crete we must turn for the earliest use of the shell-trumpet; there it was a regular accom. paniment of Minoan temple-worship.

The Maya evidence, only a part of which is dealt with here, thus confirms what has already been said concerning the ideas expressed in the Aztec picture writings, i.e, the use of shell-trumpets in temple-worship and the association of the conch-shell with the god of the moon in India and Central America.

It is altogether incredible that merely by chance the 
Maya or Aztec artist could have invented such striking jdentities, without any knowledge of the fantastic designs invented in India.

In the Introduction Dr. Elliot Smith has explained how ideas of fertility, the giving of life and resurrection grew up in association with the cowrie. This chapter has revealed how all of these attributes have been transferred to the shell-trumpet not only in A sia, but also in America. In the latter country such conceptions would be utterly meaningless unless it be admitted that they were introduced from the Old World.

In Japan we find similar evidence of the transmission of the same Indian ideas, but here owing to the proximity, of their source the confusion of the elements is not so pronounced. In a picture ( $F i g .3$, plate facing) given by Picart (op.cit., vol. iv., pt. ii., 1735, pl. I 38 ), which represents a group in the Temple of Osacca, we see expressed the identical conception of the fish incarnation of Vishnu. Picart describes this group as follows: "Canon, ${ }_{111}$ called by some Travellers, the Son of Amidas, presides over the Waters, and the Fish. He is the Creator of the Sun and the Moon. This Idol, according to the Representation of him, ${ }^{12}$ has four arms, like his Father, is swallowed up by a Fish, as far as his Middle, and is crowned with Flowers. He has a Sceptre in one Hand, a Flower in another, and a Ring in the third; the fourth is closed, and the Arm extended: Over against him, there is a Figure of an humble Derotee, one half of whose Body lies concealed within a Shell. There are four other Figures at a little Distance on an Altar, each of them with their Hands closed like humble Suppliants, from whence, as from so many Fountains, flow Streams of Water."

11 J. J. Rein ("Japan," $18 S_{4}$, p. 458) refers to this well-known and " popular deity as Kuwanon (pronounced Kannon) the goddess of mercy.

11. Picart bases his account on the "Embassies of the Dutch to Japan." 
On plate $\mathrm{I} 4 \mathrm{O}$ in the same work Picart gives a representation of the supreme Deity who, according to the Japanese, created the world. The picture (Fig: 4, plate facing p. 62), taken from a group at Miaca, clearly illustrates the second incarnation of Vishnu, viz., Kurma, the tortoise. As described by Picart, the Creator of the Universe, who is black and wears a pointed crown, is seated upon the top of a large tree trunk, which is fixed on the back of a tortoise, as in the Indian picture. He has four arms and hands, with a ring in one, a sceptre in another, a flower in a third, and in the fourth a vessel or little fountain of water. A serpent is coiled twice round the trunk. Two demons, one with the head of a dog, the other with the horns of a stag, are holding the serpent near the head, while the tail portion is held by two Kings of Japan, one of whom has four faces, like Brahma, and a Sin, or demi-god. From the water, on which the tortoise seems to lie, appears a Sun half risen, in the form of a bearded man crowned with rays. With his right hand he seems to goad the tortoise forwards, and holds divers goads in his left.

The identity of this conception with that of India is patent; but it is of interest in comparison with the Maya design because the elephant-headed god (Chac) of the latter corresponds to the stag-headed dragon in Japan. ${ }^{119}$

One point of peculiar interest is the association of the Sun, which, as we have seen, is one of the chief objects of importance in the Maya picture.

How and when these distinctly Indian ideas reached Japan is not easy to define. They may have reached there with Buddhism, which, it is stated, ${ }^{114}$ entered that country

${ }_{11.3}$ G. Elliot Smith, "Dragons and Rain Gods," to be published in the Bulletin of the John Rylands Library.

114 Rein, op. cit., pp. $219 \& 448$. 
in the middle of the 6 th century A.D., and in due course took the Shinto gods into its system, just as it had already absorbed the numerous deities of Brahmanism.

Returning to America we find some further evidences of the prevalence of the "Shell-God" idea. Lovell", informs us that "Dr. Troost, in an account of some ancient remains discovered by him in Tennessee, mentions the finding of a large conch shell (Cassis flammen), with the interior whorls and columella removed, so that nothing remained but the exterior portion of the shell, which was open in front, and in it was placed a rudely shaped idol, in the form of a kneeling human figure, made of clay with pounded shells. It was ploughed up in the Sequatchy Valley."

Long, in his "Expedition from Pittsburgh to the Rocky" Mountains," I 823 , ${ }^{110}$ tells us that the Omahas possessed a sacred shell which they transmitted from generation to generation. Its origin was quite unknown. A skin lodge was built for it, and a man appointed as guardian, who resided in the lodge. It was placed on a stand and never allowed to touch the earth, and was concealed from sight by a number of mats made of skins plaited. The whole formed a large package, from which tobacco, roots of trees, and other objects were suspended. No one dared to open all these coverings in order to see the shell, for if they attempted to look upon it they were struck with instant and total loss of sight. The sacred shell was taken by the Indians on all their national hunts, and was also consulted as an oracle before any expedition was made against an enemy. The medicine men seated themselves round the sacred lodge, the lower part of which was

11: Lorell, "Edible British Mollusca," I8S4, pp. I9S-9, quoting Trans. fmor. Ethnol. Soc, vol. I., pp. 360-1: rol. ii., pp. 360 is 364.

11. As quoted in "Flint Chijs," Ly. E. T. Stevens, pp. 44S-449. 
thrown up like a curtain, and the external mat was carefully removed from the shell, that it might have air. Some of the consecrated tobacco suspended from the coverings of the shell was taken by the medicine men and smoked to the "Great Medicine." During this ceremony everyone listened most attentively, hoping to hear a sound proceed from the sacred shell. At length someone imagined he heard a noise resembling a forced expiration of air from the lungs, and this was considered a favourable omen, and the tribe prepared for the expedition, confident of success. If, on the contrary, the shell obstinately remained silent, the result of the expedition was regarded as doubtful.

A. P. Niblack, in his work on "The Coast Indians of Southern Alaska and Northern British Columbia "117 gives some interesting details of the traditions and myths of the Tlingit, Haida, and Tsimshian tribes of the north-west coast, in which are expressed many ideas concerning the religion and cosmogony of these people. Among the Flaida, it was believed, the creator of all things and the benefactor of man was the great raven called $N e$-kil-stlas. This mythical personage was no ordinary bird, but had many human attributes, and was capable of transforming himself into anything in the world. The stories of his adventures in peopling the world are numerous. One of the most interesting of these stories is given by Niblack, as follows: "According to the Haida and Kaigani the first people sprang from a cockle-shell (Cardium corbis, Mast.). Ne-kil-stlas became very lonely and began to look about him for a mate, but could find none. At last he took a cockle-shell from the beach, and marrying it, he still continued to brood and think earnestly of his wish for a companion. By and by he heard a faint cry in 117 Report U.S. Nal. Mus., $1887-8$ (1890), p. 378. 
the shell, which gradually became louder till at last a little female child was seen, which by degrees grew to be a woman and married the raven. From this union came all the Indians of the region."

Thus preserved in the traditions of these people is the identical conception which we have already observed in pictorial manuscripts of the Mayas-the idea of the birth of a female child from a sea-shell. Such a striking similarity can hardly have been the result of accident. Turning to Ellen C. Semple's interesting book on "Influences of Geographic Environment" (London, I9I I, p. 395) we find that these widely-separated peoples-the Haidas and Tlingits of British Columbia and Alaska and the Mayas of Yucatan-have been linked together on other cultural grounds.

In the Pacific Islands, especially in Samoa, there exists a persistent belief in the presence of gods in conch-shell trumpets. Some of the information relating to this idea, extracted from Turner's interesting account of Samoa, has already been given on an earlier page, where also allusion has been made to the use of shell-trumpets at moon ceremonies. Other gods, Turner informs us, are said to be incarnate in the cuttle-fish, as well as in the large white "cowry," (Ovulum ovum); while Nonia, a village god, was supposed to be present in the cockle-shell. Concerning the origin of man some curious ideas are expressed in the traditions of these people. It is believed that man is formed from a species of mussel and that he casts his skin like shell-fish; from a man called Ariari (to appear) and a woman sprang the cuttle-fish and the race of men. Another of their traditions is that $L u$ had a wife, Gaogaoo-le-tai (expanse of sea), who had a son also called $L u$ and she next brought forth a lot of all kinds of shell-fish. ${ }^{118}$

Codrington, in his "Melanesians" (Oxford, I89 I, p. 26) 118 Turner, op.cit., pp. 8, 9, 12. etc. 
tells that in the New Hebrides there is a tradition that the first woman sprang from a cowry-shell; there is also a family named after the Octopus.

Nor is this strange "Shell-God" idea confined to the Far East. There is the ancient legend of the birth of Venus from a sea-shell. The representation of shells on the coins of ancient nations ${ }^{119}$ affords evidence of the prevalence of similar ideas in the Mediterranean region. Even in the Christian architecture of this city the same curious symbolism is depicted. In an account on the "Misereres in Manchester Cathedral," ${ }^{220}$ the Rev. E. F. Letts figures and describes a series of elaborate carvings under the stall seats portraying numerous fabulous animals in a variety of ingenious and grotesque forms. Included amongst them is one carving of peculiar interest from its bearing upon the matter under discussion. This singular subject is to be seen on the under-master's stall, and represents a mermaid or female child emerging from a conch-shell and in the act of thrusting a spear down the throat of a terrible horned dragon, whose agony is well represented in the convolutions of its tail. Letts says: "I find the subject of children emerging from shells and fighting beasts is a common one, and represents purity. conquering sin."

Another remarkable association of the conch-shell and the dragon is to be seen as the crest over a coat of arms of Robert Venables, of Antrobus, 1663 (also I 566 and 1580 ); but here it is the dragon which is emerging from the mouth of the shell. This is figured by W. H. Rylands in a communication on "Some Cheshire Heraldic Documents, from the Ashmole Manuscripts." 121

110 The shells on these coins undoubtedly represent sacred objects and the symbol a calt.

120 Trans. Lanc, and Chesh. Antiq. Soc, vol. iv., I886, p. I42.

121 Trans. Hist. Soc. Lanc, and Ches, vol. 1xii. (N.S. vol. xxvi.),, Liverpool, 19I I, p. I22. 
In his lecture upon "I)ragons and Rain Gods," which is now in course of publication in the Bulletin of the John Rylands Librory, Dr. Elliot Smith called attention to the fact that the American "long-nosed" or elephant-headed god (which represents the Indian Indra) has also the same attributes as the dragon in China and India. The "longnosed" god is sometimes represented emerging from the shell, like the dragon of the Venables coat of arms.

Regarding the supposed relations between the moon and shells, the following remarks, given by Johnston, in his "Introduction to Conchology," are not without interest. He tells us that "among the earlier naturalists it seems to have been a prevalent belief, that oysters and other bivalves were fat and in season at the full moon, and lean and out of season at the new moon." On this point, Cicero ("De Div.," ii. I4) states: "Ostreis et conchyliis omnibus contingit, ut cum luna pariter crescant, pariterque decrescant." Gellius tells the following story: "The poet Annianus, on his Falerian estate, was wont to spend the time of vintage in a jovial and agreeable way; and he had invited me and several other friends to pass those days with him. When we were at supper there, a large quantity of oysters was brought from Rome; but when they were set before us, they proved, though many, yet all poor and thin. The moon (remarked Annianus) is now in truth waning; and on that account the oyster, like other things, is lean and void of juice. We asked what other things waste when the moon is old? Do not you remember (said he) what Lucilius says?-

'Luna alit ostrea, et implet echinos, maribu fibras

Et pecui addit.'

Those very things which grow with the moon's increase pine away as it wanes; the eyes of cats also become fuller or smaller according to the changes of the moon. 
But that is still more surprising which I have read in l'lutarch, - that the onion becomes green and flourishing as the moon wastes away, and drics up again while the moon increases; and this is the cause, say the Egyptian priests, why the Pelusians do not eat the onion; because it alone of all potherbs has its turns of climinishing and increasing contrary to those of the moon." (Johnston, wp. cit., pp. 336-7). Kirckringius, it is stated, "knew a young gentlewoman whose beauty depended upon the lunar force; insomuch, that at full moon she was plump and handsome, but in the decrease of the planet so wan and ill-favoured, that she was ashamed to go abroad, till the return of the new moon gradually gave fulness to her face, and attraction to her charms. If this seems strange, it is indeed no more than an influence of the same kind with that which the moon has always been observed to have upon shellfish, and some other living creatures." He quotes Lucilius, and the words of Manilius:

"Si submersa fretis, concharum et carcere clausa,

Ad lune motum variant animalia corpus."

"This opinion," says Johnston, "continued to be for long a part of the popular crecd, and even so late as 1666 it had in nothing been impaired, for, in the 'Philosophical Transactions' of that year, travellers to India are solicited to inquire, "whether those shell-fishes that are in these parts plump and in season at the full moon, and lean and out of season at the new, are found to have contrary constitutions in the East Indies'- a nice question, to which the answer returned was, "I find it so here, by experience at Batavia, in oysters and crabs." (Johnston, op. cit., p. 337). 
Cilatter III.

\section{The Geographical Distribution of the use of Pearls and Pearl-shell.}

For many centuries pearls have been objects of commerce between nations, and from their peculiar beauty and splendour they have been held in high estimation among many peoples, civilised and barbarian. Superstitious reverence in one form or another has also been accorded them, and they have been considered as symbols of purity, beauty, and nobility, besides being regarded as emblematical of conjugal bonds. More curious still is the fact that for ages pearls or pearlshells have been supposed to possess valuable medicinal qualities, and have been used 'in medicine, either as a powder or as one of the chief ingredients of pills, especially in Oriental countries.

Regarding the origin of pearls many wild and extravagant ideas have been advanced in the past by different peoples, one of the most curious of these notions being the belief that they were formed from drops of rain falling into the gaping valves of the pearl-shell. This "congealed dew-drop" theory is remarkable for its wide distribution. It was current among the ancient people of 


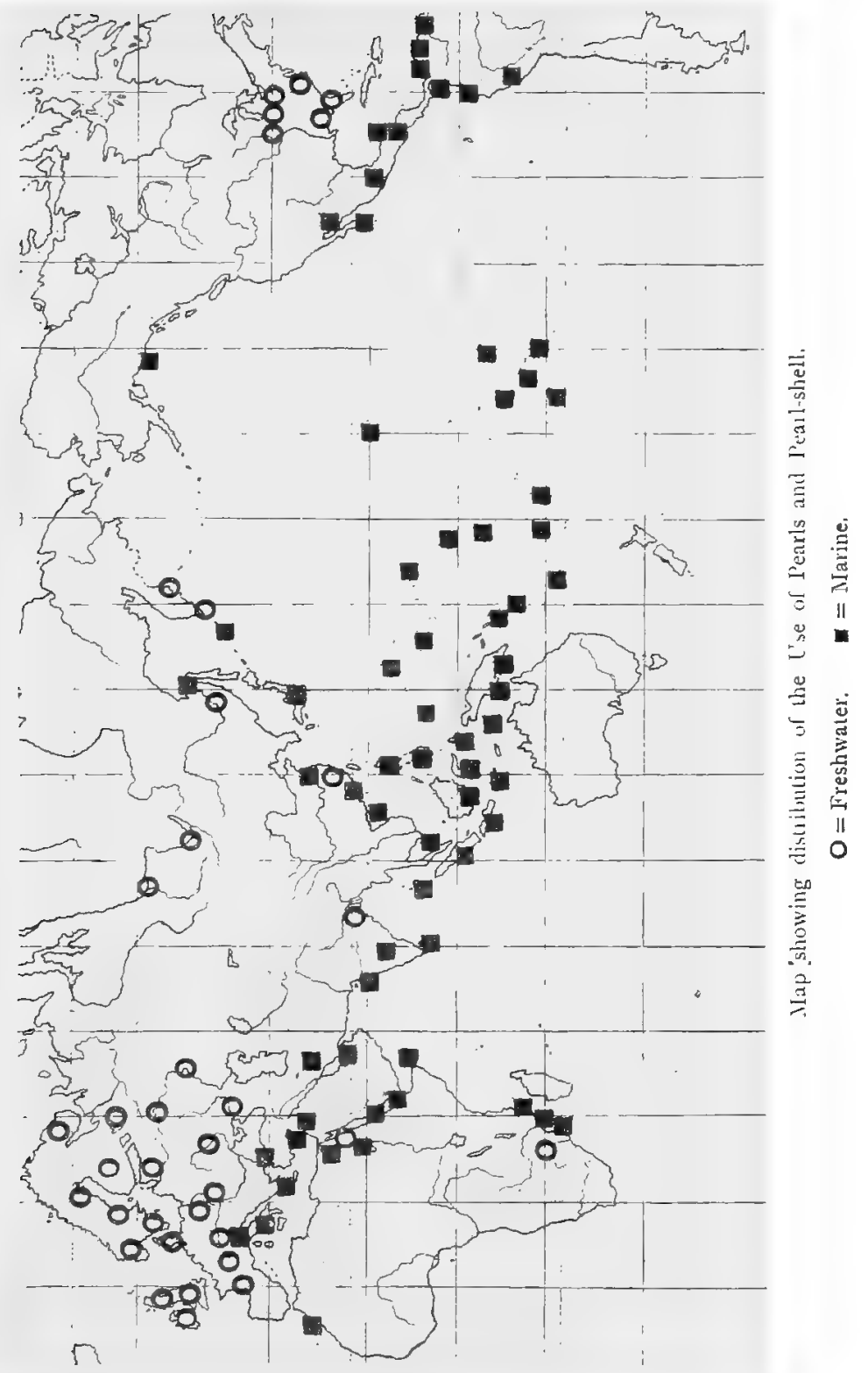


the Mediterranean, spreading from there to India, China, and other places, and was found by Columbus to exist among the inhabitants of the New IForld.

In previous papers attention has been called to the intimate association which exists between the special appreciation of pearls and the greographical distribution of elements of a culture, including amongst other things, the use of shell-purple for dyeing, and of conch-shells for trumpets. The evidence concerning the spread of these latter cultural elements has already been given, ${ }^{1}$ and the object of this chapter is to present some of the facts connected with the distribution of the use of pearls and pearl-shell.

The remarkable manner in which the sources of pearls and pearl-shell coincide with the distribution of megalithic structures has been emphasised by Mr. W. J. Perry in his recently published paper on "The Relationship between the Geographical Distribution of Megalithic Monuments and Ancient Mines." " Some further facts in demonstration of this are included in the present communication.

When the fashion for pearls and pearl-shell was first instituted is not known, but the available evidence suggests that it originated somewhere in the vicinity of Egypt, if not in Egypt itself. From this centre the fashion spread to surrounding nations of antiquity, and at a later time, together with an extraordinary collection of fantastic practices and beliefs, it was carried far and wide, eventually reaching the Far East, Oceania, and the New World. Phœenician influence was undoubtedly largely instrumental in the distribution of the appreciation of the pearl, and in the course of trade these ancient mariners inaugurated extensive pearl-fisheries in many of the places

1 Chapters I. \& II.

" Manch. Menoirs (Lit. \& Phil. Soc.), vol. lx. (1915), No. I. 
they visited. Not only were the highly-prized marine pearls sought for, but also those from the freshwater pearl mussels of the family Unionidae.

The Red Sea is probably the most ancient of the known sources of pearls. Grems from this neighbourhood were known many centuries before the Christian era, and the fishery was in a flourishing condition in the time of the Ptolemies. These pearls are referred to by Strabo, Alianus, and other classical writers." The most interesting feature in connection with these fisheries is the fact that the ancient inhabitants of the shores of the Red Sea vere acquainted with an artificial method of producing pearls. According to the philosopher Apollonius, ${ }^{4}$ the inhabitants rendered the sea smooth by flooding it with oil ; they then dived into the sea and halting alongsicle the pearl-oyster they induced it to open by holding out a case of myrrh before it as a bait. The oyster was then pierced with a long pin and the liquid which exuded from the wound was received into an iron block which was hollowed out in regular holes, where it petrified in regular shapes, just like the natural pearl. Though the details as to the method of procedure are scarcely credible, it is not improbable that the story has some sound foundation, and that attempts were really made at that early time to stimulate the growth of pearls. This interesting fact is of some importance in connection with the artificial production of pearls in India and China, to which attention is called on later pages.

From the proximity of the Red Sea to Egypt it is not surprising that the pearl-shell was known to the Egyptians

3 Kunz and Stevenson, "The Book of the Pearl," Nezc Iork, rgos, pp. $139 \mathrm{seq}$.

"Philostratus, "The Life of Apollonius of Tyana," bk. iii., ch. Ivii. (Edit. Conybeare, vol. i., 1912, p. 343). 
at a very early period in their history. In their search for the Red Sea cowries, and other shells, used as desirable objects for placing in the graves of the dead in l're-dynastic and later times, they must have soon become familiar with the mother-of-pearl shell. ${ }^{5}$

According to Kunz and Stevenson (op. cit., p. 6) the pearl-shell was in use as an ornament in ancient Egypt as eariy as the vith dynasty. In investigating the ruins of ancient Thebes, Dr. J. T. Dennis discovered several of these shells bearing cartouches of that period. In graves of the xirth dynasty, Red Sea pearl-shells have been found engraved with the name of Senusert I. ${ }^{6}$ These shells are perforated with two holes for wearing as a pectoral pendant, as in the Pacific Islands and elsewhere. In the 'pan graves' of the same period, mother-of-pearl bracelets occurred made of narrow strips of shell, perforated at each end and threaded together, thus forming a flexible band. ${ }^{7}$ Similar discoveries have been made in Nubia."

The presence of the marine pearl-shell in Egypt has been looked upon by some authorities as indicating an early trade with India. On this point Iacouperie" remarks: "Commercial relations between the Kushite emporia of South Arabia, the West coast of India, and

* It is of interest to note that the use of cowries is intimately associated with that of pearls in most of the area occupied by the megalithic culture.

" W. M. Flinders Petrie, "Amulets," London, 1914, p. 27, pl. xliv, fig. II $2 a$. An exactly similar specimen, engraved with the same name, from Rifeh, I907, is in the Manchester Museum.

" W. M. Flinders Petrie, "Diospolis I'arva, The Cemeteries of Al,adiyeh and $\mathrm{Hu}, \mathbf{I} 898-9$;" I90I, p. 46, pl. xl.

"G. A. Reisner, "The Archeolugical Survey of Nubia." Report for 1907-08, vol. i., Archaological keport, Cairo, 1910, p. 54, pl. 706.

"T. de Lacouperie, "Western Origin of the Early Chinese Civilisation," London, 1894, 1'p. 97.98. 
the South as far as Ceylon, were perhaps already opened at the time of the xirth dynasty of Egypt." But, he goes on to say, "the proof is not above suspicion. It consists of a shell of mother-of-pearl, such as those of Ceylon, which, inscribed with the cartouche of Usurtasen, was bought in Egypt in 1883 by l'rofessor Sayce. It may have been engraved long after the reign of that sovereign." There is no reason, however, to doubt the authenticity of this specimen in the light of the more recent discoveries mentioned above, but the evidence of its Ceylon origin is untrustworthy. As the same species of pearl-shell inhabits the Red Sea, it is more probable that this was its true source.

In addition to the mother-of-pearl shell, pearls themselves were used by the Egyptians, though from an examination of representations of the costumes of ancient Egypt, they do not appear to have been employed to any great extent in their decorations. ${ }^{10}$ They are represented on old Egyptian monuments, and diadems of pearls have been found from time to time in ancient sarcophagi. From about I 500 B.C., Egyptian women wore earrings, generally simple loops of gold, from which hung pendants of precious stones and pearls. They, likewise, wore necklaces made of alternate rows of shells (cowries, etc.), coral, scarabei, precious stones and pearls. One ornament worn by both sexes was the gorget, upon which pearls were embroidered in elaborate patterns." It was not, however, until after the Persian conquest in the fifth century B.C. that pearls were used extensively."

The Egyptians were also familiar with their own local

10 Kunz and Stevenson, op. cit., p. 6.

11 L. W. Streeter, "I'earls and I'earling Life," Londun, I886, pp. $33 \cdot 34$.

12 Kunz and Stevenson, op. cit., p. 6. 
freshwater pearl mussels, tetheriu (Nile oyster), Unio, etc. at a very early period, using their valves as receptacles for paints, etc, in Pre-dynastic and later times. Whether they obtained pearls from these is not known, but the pearly nature of the shells themselves may have led to their being objects of appreciation. The tetherie occur in the Nile as high as the cataracts of Robâtâs in Upper Nubia, and are clescribed by Cailliaud, in his "Voyage à Méroé," as being a common article of food. Their shells are collected by the natives in order to decorate the tombs of deceased relatives. ${ }^{13}$ Perforated discs of this shell were found in some numbers in a tomb of the xvinth dynasty (grave D I I4) at Abydos, , but whether they were used for ornamental purposes, such as necklaces or, armlets, is difficult to decide. Judging from their size (diam. $27 \mathrm{~mm}$.) they would not prove suitable objects for this purpose. There is no evidence to suggest that they were employed as a form of currency.

Beyond the reference by l'liny ${ }^{1 \overline{5}}$ to pearl fisheries on the Mauritanian coast-probably inaugurated by the Phennicians, who visited West Africa for gold-little is known of the use and exploitation of pearls in this part of Africa.

On the east side of the African continent, pearl fisheries are known south of the Gulf of Aden. According to Kunz and Stevenson (op. cit., p. 153) "little information exists as to the origin of these fisheries. In a paper published by the Lisbon Geographical Society, January, 1903, Señor Irens Ferranz states that, according to tradition, in remote times the Ibo Archipelago, on the

3 s Nary Robert, "I"ipular Hintory of the Mollusca," I85I, p. 3 II.

${ }^{34}$ T. Lric Peet and W. L. S. Loat, "The Cemeteries of Abydos," pt. iii., 1912-13. 35th Mem. of Egypt Explor. Fund, igr 3, p. 30, pl. xii.

15 P'liny, "x.Iu.," bk. ix.. ch. 56. 
north-east coast of Portuguese East Africa, was inhabited by a Semitic colony, which located there to fish for pearls, and these were carried through the Red Sea to King Solomon. He adds that there is little doubt that, after the great emigration which started from the Persian Gulf in 982 and founded Zanzibar, Kilwa, and Sofala on the coast, some Arabs engaged in fishing for pearls about the islands near Sofala."

The evidence of early pearl fishing on the coast of East Africa is significant in view of the implied association between megalithic culture and pearls. In the map which illustrates Mr. Perry's paper (op. cit., p. ro), the presence of the pearl-shell is not indicated on the coasts of Zanzibar and Madagascar" two localities which are suggestive when the presence of megalithic monuments in Rhodesia and Madagascar is recalled" (P. I I). Another important link is afforded by the discovery of beads made from the shell of the common Unio or fresh-water mussel (Unio verveauxi) in graves in the vicinity of Bulawayo, Rhodesia ${ }^{16}$

The l'ersian Gulf has been famous as a source of pearls from ancient times. A very early origin of pearl fishing here seems to be indicated by a cuneiform inscription on a broken obelisk, erected presumably by a ling of Nineveh, which has been translated by Jules Oppert, the eminent Assyriologist. ${ }^{17}$ The fisheries were well known in the time of Alexander, and are referred to by Pliny ${ }^{1.4}$ as yielding the most valuable pearls. Isiclorus of Charace, a Greek historian, circa 300 B.C., mentions the pearl fishing in this neighbourhood in his account of the Parthian Empire, and gives a fanciful story of the influence of thunderstorms on the brecding of pearls. ${ }^{1.4}$

10 Kunz and Stevenson, op, cit., p. 513.

17 libil., p. 85 .

is Pliny, "N.H.," bk, ix., ch. 54.

19 Athenecus, "Deipnos," bl, iii, , ch. 46. 
The inhabitants of the Island of Bahrein-the Tylos of P'tolemy-have been devoted to pearling from time immemorial, and the fishing to-day is carried on much as it was 2,000 years ago. This island was in touch with Chaldean civilization, and one of the traditional sources of the Phonicians, and whence came that fish-god whoaccording to the Babylonian myth-bore the ark over the deluge. ${ }^{20}$

In Persia, pearls were almost certainly known in the seventh century I3.C.; they are not mentioned in the extant fragments of ancient literature, but pearl ornaments of great antiquity have been found among l'ersian remains. Assyrian and P'ersian bas-reliefs show that pearls were used profusely for adornment by the sovereigns and great personages of those countries. The portraits of l'ersian queens on coins and gems commonly show earpendants of pearls. ${ }^{{ }^{1}} \quad$ Portraits of Sassanian kings show a pearl pendant of large size hanging from the right ear, and among Persian nobles it was the custom to wear in the right ear a golden ornament containing pearls. The women also wore a ring through the left nostril, upon which three pearls were strung, and round their heads was a band with penclent jewels or pearls. The kings of the Medes and l'ersians wore bracelets and necklaces of pearls, and these gems were employed lavishly in their trappings and equipages. At the present lime pearls play a prominent part in great festivals in I'ersia."'

Among the ancient Persians a solar orisin was attributed to the pearl.:

Babylonian dignitaries and priests, it is stated, wore

20 Kunz and Stevenson, op. rit., pp. $90 \mathrm{ctg}$.

21 Ibid., pp. 5 and 404.

" s Streeter, op. cit., PP. 30-3I.

23 Ibid., p. 48 . 
strings of pearls, most of which no doubt came from the lersian Gulf fisheries." In the ruins of Babylon, however, no pearls have been found ; the relatively moist soil containing much saltpetre may account for their non-survival for so many ages.

According to Kunz and Stevenson (op. cit., p. 405), one of the most interesting examples of the use of a pearl in ancient times is a beautiful prehistoric pearl pin from Paphos, on the Island of Cyprus, which is mounted with a large marine pearl measuring $14 \mathrm{~mm}$. in diameter, and weighing about 70 grains. It is surmounted by a small fresh-water pearl $4 \mathrm{~mm}$. in diameter.

In excavations made in the Huaran district in Syria, a number of pearls were found in a rock-cut tomb said to be of Roman origin. The pearls were still attached to a bronze wire with which they had been strung. A pearl pin and a single earring bearing a pearl have also been recorded from a rock-tomb at Cæsarea, in Syria. ${ }^{26}$

Pearls were esteemed by the Greeks in the time of Homer, who appears to allude to them under the name

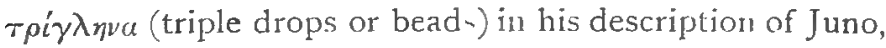
in the Iliad, xiv., 183; and in the Odyssey; xviii., 298. Classical designs of Juno usually show the three pearshaped pearls pendent from her ears. The pearls of the ancient Greeks were obtained probably through the medium of the Phoenicians, and during the Pcrsian wars of the fifth century B.C., they doubtless extended their acquaintance with these beautiful gems. ${ }^{27}$

The necklaces and earrings, on the heads of female divinities, goddesses, and nymphs, represented on Greek coins from the fifth century B.C., are considered by many

\footnotetext{
24 Tbid., p. 3 I.

25 Kunz and Stevenson, op. cit., p. 5.

20 Ibid., p. 406.

23 Ibid., p. 8.
} 
numismatists to be intended to represent pearl ornaments. ${ }^{-3}$

Theophrastus, writing about $300 \mathrm{KC} .$, mentions the gems, and describes them as the product of shell-fish. In his day they were valued for necklaces or bracelets. Pliny also refers to other Greek writers on the subject. Like the Persian nobles, Grecian men of rank wore one pearl earring in the right ear, while the women wore one in each ear. ${ }^{29}$

Interesting evidence of the ancient appreciation of pearls in the neighbourhood of the crimea is furnished by the discovery of gold earrings with pearl centres, probably of the first half of the third century A.D., in a tomb close to the site of the ancient town of Chersonesus, and of earrings and pins set with pearls, from the neighbourhood of Tiflis. An earring, of fourth century date made of gold wire, on which seven pearls are threaded, said to have been found on the site of the ancient Greek colony of Olbia, is of special interest in view of the fact that the pearls are drilled. Another interesting find, also of the $4^{\text {th }}$ century A.D., is that of a brass clress pin with a sphere of amber, surmounted by a pearl, found near the village of $\mathrm{M}$ zchet Caucasus. ${ }^{30}$

The custom of wearing a ring, ornamented with corals, pearls or precious stones, was prevalent among the fashionable Tartar ladies of Astrakhan, in the I8th century. This was worn suspended from the perforated right nostril, and recalls a similar practice among the women of P'ersia (supra, p. 78 ). "

2 \& Ibid., p. 409.

2: Streeter, op. cil., p. 35 ; Kunz and Stevensen, op. cit., p. 8 .

in liunz and Stevenson, op. cit., p. 410.

$=1$ G. A. Cooke, "System of Universal Geography." London (1801). rol. i., p. 448 . 
From Greece the admiration for pearls spread to Rome, where they were known by the Greek word margarita, as well as the Roman name unio. According to Pliny (bk. ix., ch. 59), the Romans used the latter name to distinguish a pearl of remarkable size. This celebrated Roman naturalist, who regarded pearls as formed by dew or rain falling into the gaping shells of the pearl-oyster, ${ }^{32}$ tells us that after the surrender of Alexandria, these gems came into common, and indeed universal, use at Rome; but they first began to be used there during the Jugurthan wars. ${ }^{33}$

The Romans were deeply affected by pearls, and these gems took precedence over all others. Roman ladies wore necklaces and ear-drops of pearls, and dresses were lavishly covered with these gems. They were worn even at night that in their sleep the owners might be conscious of the possession of such valuable jewels. Pliny, ${ }^{84}$ gives us a graphic description of the pearls and other ornaments worn by the Roman empress Lollia Paulina at an ordinary wedding entertainment. It was not unusual for the Romans to adorn their horses and other favourite animals with splendid necklaces; and it is said that "Incitatus," the favourite horse of the Emperor Caligula, wore a pearl collar. Pearls also decorated the altars in the Roman temples, and the furniture of the houses, while their warchariots shone with them. Philo Judrus speaks of the couches upon which the Romans reclined at meal-times as being ornamented with tortoise-shell and ivory, and shining with gold and pearls. He also adds that upon the couches lay purple coverings embroidered in gold or pearls. Under successive emperors sumptuary laws were

s 2 Pliny, "N.H." lk. ix., ch. 54 .

s3 Ibid., bk, ix., ch. 59 .

s4 Ibid., bk. ix., ch. 58 . 
issued in order to stem the tide of extravagance which threatened the ruination of all classes. Julius Casar issued an edict, prohibiting the use of purple and pearls to all persons who were not of certain rank, and the lat ter also to unmarried women. ${ }^{3.5}$

The mother-of-pearl was evidently appreciated in Northern Italy long anterior to the time of the Roman Empire, as the shell of the pearl-oyster of Eastern seas has been found in ancient hut foundations, reported to bc of Neolithic age, near Reggio Emilia. ${ }^{36}$ This discovery would seem to indicate very early intercourse with the advanced culture of the East. Further evidence in support of this is furnished by discoveries of conch-shell trumpets and broken Purpura shells in Ligurian caves, to which attention has been called in the other chapters of this book.

It is probable that the ancient Hebrews valued pearls for ornamental purposes, doubtless obtaining them by commerce with the Phonicians. It is remarkable, however, that the Hebrew word, gâbish, translated "pearl," occurs but once in the Old Testament. Some doubt exists even here as to the true significance of the word, some writers claiming that it relates to some other substance, probably "crystal." In the New Testament anc! in the Talmud are to be found frequent references to pearls, which show how these gems were estimated by the Jews. Mother-of-pearl is still a commodity of general traffic in Palestine, where it is carved by the inhabitants into various religious ornaments. ${ }^{37}$

35 Lovell, "Edible British Mollusca," I884, p. 92 ; Streeter, op, cil., pp. 39-40; Kunz and Stevenson, op. cit., p. 9.

s\& Musso, "The Dawn of Mediterranean Civilization," 1910, p. 269, quoting Colini, Atti della Società romana a"Antropologia, vol. x., 19014.

s 7 Streeter, op. cit., p. 32 ; Kunz and Stevenson, op. cit., pp. 6-7. 
Although the pearls used by the ancient people of the Mediterranean were largely those obtained from the true pearl-oyster, pearls from other sources seem also to have been employed. Pliny ${ }^{38}$ informs us that they used formerly to be found in the seas of Italy, but more frequently about the Thracian Bosporus; they were of a red colour, and small, and enclosed in a shell-fish known by the name of "mya." Off the coast of Acarnania they were obtained from a shell-fish called "pina," ${ }^{39}$ but the pearls were ill-shaped, and of marble hue; those found about Cape Actium were better, though of small size.

Pearls have been associated with the name of Britain from very early times. According to Suetonius, the great motive of Cæsar's expedition into Britain in 55 3.C., was to obtain its pearls, which were so large that he used to try the weight of them by his hand. Pliny ${ }^{40}$ confirms this, saying that Casar dedicated a breastplate covered with British pearls to Venus Genetrix, and hung it in he: temple at Rome. The British pearls, doubtless obtained from the fresh-water pearl-mussel, Margaritana margaritifera, seem to have been regarded by ancient writers as dull in colour and lustre and inferior to the pearls of the Orient.

The imperial diadem of the sovereigns of the ancient Britons, Whitaker remarks, was sometimes encircled with an ornament of the mussel-pearls, as appears from the coins which have come down to us. ${ }^{41}$

That the pearl or pearl-shell was appreciated by the inhabitants of Britain as early as the Neolithic age seems

ss Pliny, “N.H., ” bk. ix., ch. 56 .

sa Pearls are frequently olstained from the Pinna-shell at the present day.

40 Pliny, "‥H.," bk. ix, ch. 57.

41 Whitaker, "History of Manchester," and ed., London, 1773, vol. i., pp. 22 and 342 . 
very probable from the discovery of the shell of the fresh-water pearl-mussel (Margaritana margaritifera) associated with human remains in the sepulchral cave at Perthi Chwareu, near Llandegla, Denbighshire.

The presence of fragments of pearl-shell in the paste of early hand-made pottery may also be an indication that the Early Britons considered the shell as auspicious and consequently adding further value to their product, analogous to the use in India of lime obtained by burning both chank and pearl oyster shells. It is significant how widely spread are both these customs. The shells of Unio are recorded from North American Indian graves where they had been placed to serve as food for the dead during the journey to the land of spirits; and fragments of Unio shells were used by the Indians to temper the clay for pottery. Beads of Unio shell have also been found in graves in the neighbourhood of Bulawayo, Rhodesia, as already stated.

An interesting survival of the Greek word $\tau \rho i \gamma \lambda \eta \eta \alpha$ (triple drops or beads, i.e, pearls) seems to exist in the Welsh glain (bead), the name having been carried to Britain by Phoenician tradcrs." It is well known that the Phonicians, after founding many colonies in the Meditcrranean, passed on through the Straits of Gibraltar, and in course of time probably reached the British Isles. Here no doubt they became acquainted with the pearls of the British rivers.

The principal fresh-water pearl fisheries in the British Isles are those of the Conway River, in North Wales, where it is supposed Casar obtained his pearls; the Irt, in Cumberland ; the Tay, Earn, and Teith, in L'erthshire; the Dee, Don, and Ythan, in Aberdeenshire; the Spey

4 a J. W. Jackson, Lancashive Naturalist, Dec., 1913, pp. 32 I-2.

43 Kunz and Stevenson, op. cil., p. 8. 
and Findhorn, in Inverness-shire; and the rivers of the counties of Kerry, Donegal, Tyrone, Wexford, etc., in Ireland. These fisheries have been described by many writers from the time of the Venerable Recle (673-735 A.D.) to the present day, and allusion has been made to the prevalent belief in the dew-drop origin of the gems.

On the continent of Europe the abundance of pearls in the mussels of the lakes and rivers has also given rise to many important fisheries. Little is known, however, of their early history, except that some of these localities appear to have been exploited by the Romans. It is probable that some are of an even earlier date, possibly owing their inauguration to Phonician influence, as in the British Isles.

The principal areas where pearl fishing has been carried on in modern times are France, Germany, Austria, Scandinaria, Denmark and Russia.

In the east of France the pearl fisheries of the Vologne, in the department of the V'osges, are of special interest and have been celebrated for centuries, while in the western part of the country the pearl mussels have been exploited in the Adour, the Charente, the Gironde and tributaries, the Garonne and the Dordogne and their affluents, and many other streams. In Germany the pearl fisheries are most important in the streams of the southern districts, in Bavaria, Saxony and Silesia. In Austria the fisheries have been prosecuted in the province of Bohemia from very early times. The fisheries of the Wottawa River were noted in 1560 and this river has long been known as "the gold- and pearl-bearing brook." Formerly along its shores, gold washing was more or less carried on, as well as the fresh-water pearl-mussel industry. In Hungary the native pearls have been popular with the Magyar wumen from early times, and very many yet 
exist in old Hungarian jewelry. In Denmark no pearl fisheries now exist; but three centuries ago the gems were obtained in the Kolding Fjord, in Jutland. In Norway most of the rivers and streams, especially on the west and south-west coast, have been noted for pearls from the $17^{\text {th }}$ century; while in Sweden, pearl fisheries were noted, in I562, by Olaus Magnus, Archbishop of Upsala. In Russia the pearl mussel is found in many streams; it occurs throughout Archangel, in most of the rivers flowing into the White Sea, Lake Onega, and the Baltic Sea; it likewise occurs in the Volga Watershed. In the government of Archangel pearls have been collected for centuries from the streams flowing into the White Sea and Arctic Ocean. Middendorff gives us a detailed account of the Lapland pearl fisheries and relates that they have been carried on exclusively by the shore Laplanders; but owing to the small returns, they have been neglected in recent times. The pearls obtained are somewhat dull in colour, which in the opinion of the fishermen is caused by the mysterious influence of the copper money which they carry with them. The Tuloma was formerly a productive river; its pearls were sold in Kola, and were sent from there to Archangel to be pierced. The Tjura also yielded many pearls; but since a Laplander was drowned while fishing for them, the idea has spread that the spirit of the river guards the pearls, and the natives hesitate about seeking them. In the grand duchy of Finland, in the province of Olonetz, and in the Baltic Provinces, pearls have been sought after for three centuries or more. The areas where pearl fishing is conducted in other parts of Russia - the Volga Watershed, the Don, the Dnieper, etc.—are indicated on the accompanying map."

44 The above information is mostly extracted from Von Ilessling "Die Perlmuscheln und ihre Perlen," Leipzigr, 1859; also Küunz and Stevenson, op. cit. 
In India pearls were known and appreciated many centuries before Christ. They are frequently mentioned in Indian mythology, their discovery being attributed to Krishna, the eighth avatar or incarnation of Vishnu, who is said to have searched the ocean for these gems and then carried them to India as a wedding gift to his daughter Pandaïa. The Atharvaveda (at least 500 years B.C.), alludes to an amulet made of pearls and pearl-shell used for bestowing long life and prosperity upon young Brahmanical disciples. ${ }^{+5}$ The two great epics of ancient India, the Ramayana and the Mahabharata, also refer to pearls, and the former speaks of a necklace of twentyseven of these gems, and refers to pearl drillers accompanying a great military expedition. Ancient Indian deities are represented as being adorned with these gems, and, according to Varahamihira, the Indian astronomer, the statue of the Sun-god, Mithra, wore a crown upon his head, and was decked with chain-work of pearls, and earrings also of pearl. Pearls and diamonds served as eyes for images of the gods; they were also employed to decorate the interior of Buddha's tomb, and shone upon the beautiful box containing his sacred tooth. Distinguished Indian women wore purple draperies ornamented with pearls, and on great public occasions their arms were covered with them; and they even wove them into their hair. ${ }^{48}$ Special esteem seems to have been accorded to rose coloured pearls, for red pearls (Lohitamukti) form one of the seven precious objects which it was incumbent to use in the adornment of Buddhistic reliquaries, and to distribute at the building of a Dagopa. ${ }^{47}$

" 5 See translation by Maurice Blonmfield in "Hymns of the Atharvaveda," Oxford, I897, p. 62.

4 Von Hessling, op. cit., pp. I-2; Streeter, op. cil., pp. 24-25; 'Kunz and Stevenson, op. cit., pp. 3-4.

" I sovell, op. cit., p. 97 ; see also Yule's "Marco I'ulo," ii., p. 203. 
Notwithstanding their great fame, the pearl fisheries of India are of small extent. The only resources are the pearl reefs situated on the Madras coast in the vicinity of Tuticorin, on the northern shore of the Gulf of Manaar; reefs of local importance at Kananur on the Malabar coast and on the Ratnagiri coast below Bombay; and the more important reefs off the coast of Nawanagar, on the south side of the Gulf of Cutch. The fisheries of the Madras coast were well known in the time of l'tolemy, and pearls from this source are alluded to by several early writers. ${ }^{48}$

According to Hornell, ${ }^{\text {t9 }}$ the ancient Tamil classics furnish evidence of the existence of important pearl fisheries, together with those of chank shells, on the Indian shore of the Gulf of Manaar. One reference contained in the "Maduraiklkanchi," a Tamil poem, " incidently describes the ancient city of Korkai, once the sub-capital of the Pandyan Kingdom and the great emporium familiar to Greek and Egyptian sailors and traders and described by the geographers of the ist and 2 nd centuries A.D. under the name of Kolkhoi."

"In one passage," Hornell informs us, "the Parawas are described as men who dived for pearl oysters and for chank shells and knew charms to keep sharks away from that part of the sea where diving was being carried on. Another passage depicts the city of Korkai, then a seaport at the mouth of the Tambraparni, as the chief town of the Parawas and the seat of the pearl fishery, with a population consisting chiefly of pearl-divers and chank-cutters."

It is of some interest to note that the Parawas to-day continue as from time immemorial to provide the con-

4 Kunz and Stevenson, op. cil., pp. 128-9.

40 James Hornell, "The Sacred Chank of India," Madras, 1914, pp. 42-3 (Tadras Fisheries Bulletin, No. 7). 
tingent of divers employed for the pearl and chank fisheries of the gulf of Manaar.

In the first century A.D. Argalus, in the neighbourhood of Korkai, appears to have been a station where the Gulf of Manaar pearls were perforated. Here also were to be purchased fine muslins sprinkled with pearls."

According to Kunz and Stevenson (op. cit., p. I $3 \mathrm{I}$ ), two other species of pearl-producing mollusks are collected in the Madras Presidency. One of these is a species of mussel, bright green in colour, known as I/jtilus smarrgdimus, collected from the estuary of the Sonnapore River, near Berhampore. Small pearls of inferior quality are found therein, and are sold chiefly for chunám ${ }^{51}$ and for placing in the mouths of deceased Hindus. The other species is the Placuna placenta-the so-called "windowglass" shell-which is abundant from Karachi, near the Baluchistan border, to the Kanara district south of Bombay. It is found also in Pulicat Lake, and in the vicinity of Tuticorin. Where it occurs in any abundance it is collected for the sake of the small pearls found therein. These pearls are highly valued by the Hindus, in calcined or porvdered form, for medicinal purposes, and especially for mixing with the betel-nut ; they are also in considerable demand for placing in the mouths of deceased Hindus of the middle class, instead of the sea pearls which are used by the wealthy, or the rice employed in a similar manner by persons of poorer rank. The practice of placing pearls in the mouth of the dead is an old one in India and was noted by Marco Polo more than 600 years ago. ${ }^{5:}$ As we shall see later on in this chapter,

su Vincent, "The Commerce and Navigation of the Ancients in the Indian Ocean," London, I807, vol. ii., p. 519.

¿1 Chunám: lime prepared from burnt shells, etc., used for building purposes, and by matives for mixing with betel for chewing.

$\checkmark 2$ Kunz and Stevenson, op.cit., p. 3 Io. 
it is also a very ancient custom in China, and, more interesting still, in the New World, where it appears to have been carried by the great wave of megalithic culture compounded of so many curious and remarkable elements. In no other way can it be accounted for here, as it is inconceivable that such an arbitrary practice could have developed independently in Asia and in America.

India is the home of many strange ideas concerning the origin of pearls. From very early times they have been considered as consolidated dew-drops, which Buddha in certain months showered upon the earth, when they were caught up by the gaping oysters whilst floating on the waters to breathe. ${ }^{5: 3}$ Streeter ${ }^{\text {; }}$ quotes many other equally curious superstitions regarding their origin, from a work by a native Indian I'rince, the Rajah Sourindro Mohun 'Tagore. In his 'Mani-Málá or a treatise on Gems,' this writer, in addition to the dew-drop theory, refers to the general belief that pearls originate in clouds, elephants, boars, conch-shells, fish, serpents, and bamboos. The cloud-begotten idea seems to be a variant of the dew-drop origin. "Pearls that originate in the head of the Elephants of Khambogia are large as the fruit of the emlic Myrobalan, heavy, and more yellow, but not more lustrous than the other kinds." "Pearls which originate in the head of the Boar are generally white, like the tusks of that animal." "A pearl derived from the conch-shell is of large dimensions, has the same colour as the inner surface of that shell-fish, and is productive of good fortune to its possessor." "Pearls attained from the mouth of seafish are singularly round, small and light. Those which

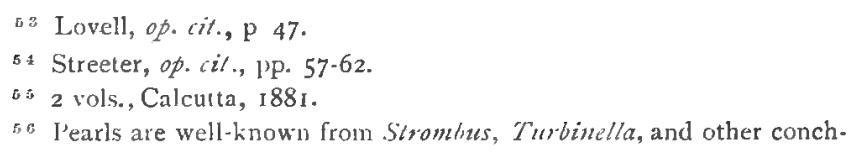
shells. 
originate in whales are agreeably round, but not highly lustrous." "s "Pearls which originate in the crest of Serpents, are beautifully round .... the serpents who bear them are the descendants of Vásuki, sovereign of the snakes, are not born everywhere, and are rarely seen by men in some sacred ground." "58 "Pearls which originate in the Bamboo are clear as the moon, and are like the Kakkol fruit in shape."

The same Indian authority says further, "In certain places pearls are found on the head of frogs; learned men class them with serpent-pearls." This prominent Indian belief which makes the head of the frog or toad Nature's laboratory for the manufacture of pearls, was at one time widely prevalent in the British Isles.

This idea is immortalized in the familiar lines of Shakespeare-

"Sweet are the uses of adversity;

Which, like the toad, ugly and venomous,

Wears yet a precious jewel in his head."

On the Indian idea of the supposed medicinal properties of pearls the Rajah Sourindro Mohun Tagore has much to say in the work already quoted. The burnt powder of these gems, if taken with water, cures hemorrhages, prevents evil spirits working mischief in men's minds, cures lunacy and all mental diseases, jaundice, etc., etc. Used as a dentifrice it strengthens the gums and cleans the teeth. Rubbed over the body with other medicines it cures leprosy and all skin diseases. And so on,

In addition to the pearls themseives, the burnt pearlshells are also looked upon as efficacinus in the cure of many ailments; but chank-shell powder appears to sur-

if Pliny, "N. II.," bk. ix.. ch. 24, mentions fish which have a "stone" in the head. He refers doubtless to the ear-bones or otoliths.

is Is this a confusion of the pearly-like granules and shields found in slugs, the 'snail-stones' credited with the property of strengthening eyes, etc.? 
pass either of these substances, the special significance and auspicious nature of the chank inspiring the confidence of patients in the value of this medicine. ${ }^{58}$

The superstitious reverence paid to these white shells by the IIinclus and other oriental people, recalls the reverence paid by the Greeks and Romans to snails and other shells. The internal pearly-like shell of some of the slugs was believed by them to be highly efficacious in the cure of fevers, diseases of the head or headaches. The granular substance representing the shell in some species was also believed to facilitate teething if suspended from the necks of infants. ${ }^{60}$ In the same category are to be included the worn fragments of shells, or "snail-stones," which were formerly much commended in Guernsey and the Highlands of Scotland as a remedy for diseases of the eyes. ${ }^{1 i 1}$ According to Humboldt, ${ }^{6,2}$ similar worn fragments of shell, known as "eye-stones" (piedras de los ojos), were regarded by the inhabitants of Araya, Venezuela, S. America, as possessing extraordinary powers in the expulsion of foreign particles accidentally introduced into the eye. Kunz" also records that "eye-stones or opthalme are taken from the crawfish in the Sandwich Islands. They have been used from time immemorial for removing dust or other particles from the eye." These "eye-stones" are probably the so-called "crab-stones " or "crab's-eyes," the concretions of carbonate of lime, developed on either side of the stomach in the lobsters, crayfish, etc, before the time of moulting.

59 See IIornell's interesting work on "The Sacred Chank of India," Madras Fisherie's Bullotiu, No. 7, I9I4, especially Cliap. ii.

(;) Pliny, "N. H.," bk. xxix., ch. 36 .

0 1 Johnston, "An Introduction to Cunchology," London, i 850, p. 78.

¿Ilumboldt, "Pers. Narrative," i., p. I97 (Bohn'- Ed.).

is F. I: Kunz, "Folk-lore of Precious Stones," „Memoirs Internat. Con.'. Anthrop., Chicago, 1894, p. 273. 
In Furopean countries these concretions were formerly used in the preparation of certain medicines. ${ }^{6.1}$

Like the pearl fisheries of southern India, those situated off the north-west coast of Ceylon, in the Gulf of Manaar, directly south of Adams Bridge, are of very great antiquity. They are said to have been well-known to the l'honicians who traded here in purple robes and other commodities. ${ }^{65}$ Pliny ${ }^{615}$ refers to Taprobane (Ceylon) as the most productive of pearls of all parts of the world. Ptolemy, Strabo, and other ancient writers also speak of their importance. According to the "Mahavansa," pearls figure among the native products sent as presents from King Vigaya of Ceylon to his Indian father-in-law, in about 550 B.C.; and again when in 306 B.C., King Devanampiyabissa sent an embassy to India the presents are said to have included eight kinds of Ceylon pearls. ${ }^{67}$ According to Tennent ${ }^{69}$ the eight kinds of pearls were: "haya (the horse); gaja (the elephant); ratha (the chariot wheel); maalaka (the nelli fruit); valaya (the bracelet); anguliwelalıka (the ring); kakudaphala (the kabook fruit); and pakatika, the ordinary description."

The only other locality in Ceylon where pearls are obtained is Tamblegam Lake, on the north-eastern coast, near Trincomali. Here Placuna fishing is carried on for the sake of the diminutive pearls contained in them. These are exported to the coast of India, to be burned into lime for mixing with betel for chewing. (Tennent, op. cit., ii , pp. $491-2$.)

64 Jeffreys, "Brit. Conch." i. I862, p. 1xv.

65 Streeter, op. cit., p. I86 ; Tennenı, "Ceylon," London, I859, and ed., vol. i., p. 55 I.

" s Pliny, "N.H.," bk. ix, ch. 54.

Br W. A. Herdman, "Report on the pearl oyster fisheries of Ceylon."

-Rnyal Srciety, London, pt. i., I903; also lKunz and Stevenson, op. cit., 1". 4 . is Temnent, op. cit., i., p. 446. 
We have little definite information regarding the early use of the fresh-water pearls of India except the statement in the "Periplus" that a considerable traffic, consisting of pearls, betel, Gangetic spikenard, and Gangetic muslins, passed through the market town of Ganges, situated on the river of the same name. Schoff, in his annotations of this work says "these (pearls) were not of best quality; as Dr. Taylor remarks, those of the Ganges streams are inferior, being small, often irregular, and usually reddish."

Eastward of India a most interesting pearl fishery exists in the Mergui Archipelago (Lower Burma). According to Kunz and Stevenson (op. cit., p. I34), this fishery originated with the Selangs or Salangs, a nomadic race of maritime gipsies, supposed to be of Malay descent. Their early history is unknown, and no information exists as to when these people first found profit in searching for pearls. It was probably many centuries ago, and for a long time they made contributions of them to the Buddhist rulers of Burma.

In the Malay Archipelago pearl-oysters are among the important resources of the seas surrounding Sumatra, Java, Borneo, Celebes, the Aru Islands, the Moluccas and New Guinea. For hundreds of years pearl-shell and pearls have been gathered by the natives from these waters, and especially on the coast of the Aru Islands, Halmahera, and adjacent Islands, on the east coast of Celebes, and about the Sunda group. Pearl-oysters also occur near many other islands in this neighbourhood, including the Sulu Archipelago and the Philippines. ${ }^{70}$

- "The Periplus of the Erythrean Sea : Travel and Trade in the Indian Ocean ty a merchant of the First Century." Translated from the Greek and annotated by Wilfrid H. Schoff. London, I9I2.

70 Von Hessling, op, cit., pp. $7 \mathrm{I}-4$; Kunz and Stevenson, op. cit., pp. 2 I 2 seq. 
Throughout Malaysia, including the Philippines and Sulu Islands, the pearl is known as mutya, mootara, mutyara, or some similar name, closely resembling the Sanslirit mukta, or the Cingalese mootoo, indicating the source of the influence that inaugurated the fishery and trade of this region. ${ }^{71}$

At Pados Bay, island of Borneo, Placuna fishing is also carried on, and the shells, dried meat, and the seedpearls they contain, all form important articles of commerce. The seed-pearls are used as a form of currency between the fishermen and the Chinese traders. ${ }^{72}$

Throughout the Malay Archipelago, and especially on the coast of Borneo, the natives allege that "breeding pearls" exist, that is to say, there are pearls which possess the power of reproduction or rather germination. It is the generally accepted belief that if a few pearls of good size are sealed up in a box together with some grains of rice and a little cotton wool, they will increase in number as well as in size. It is asserted that on opening the box after several months, one or more small pearls will be found therein, and the original ones none the worse; but the grains of rice will have the appearance of having their ends nibbled as if by rodents. ${ }^{73}$

In China pearls appear to have been held in great esteem since before the Christian era. They are repeatedly mentioned in the ancient literature of that country, but, owing to the traditional nature of some of these works, it is impossible to fix, with any degree of accuracy, the period when they were first appreciated. Some translators of Chinese books give a date as early as

71 Ibid.

72 Kunz and Stevenson, op. cil., p. $22 \mathrm{I}$.

7 s Streeter, op. cit., p. 69; Kunz and Stevenson, op. cit., p. 296. 
the 23 rd century 13.C., but other authorities are inclined to take a more moderate view.

One of these early Chinese works, the "Shan Hai King," presents us with some extraordinary information regarding the existence and origin of pearls. According to Streeter, "the $4^{\text {th }}$ "hook of this work, or "The Classic of Mountains and Rivers, refers to the Li river, one of the affluents of the Tung-Ting Lake, which drains the northwest portion of Hunan. 'In it are many Chu-pick fish' (or' water animals). 'These look like lungs, but have eyes and six feet, and they have pearls. They taste sour but pleasant, and are not unwholesome.' . . . The same work also states that wild animals were found which looked like sucking-pigs, but have pearls." The identity of the curious Chu-pick fish is not clear. Streeter says their existence is confirmed in Luishi's edition of the "Book of Confucius," and remarks: "they are probably cuttle-fish with six tentacles." Cuttle-fish, however, are essentially marine animals, and, moreover, possess at least eight arms, or tentacles. As mentioned previously (p. 92), concretions of carbonate of lime, resembling pearls, are found in some forms of freshwater crustaceans, such as the crayfish, but here again, though eyes are present, these animals have eight legs. It is not unlikely that the pearl-bearing animals in question were freshwater mussels, the addition of the eyes and feet being due to some confusion in the translation of the passage.

In the oldest Chinese dictionary, the "Bh'-ya," pearls are mentioned as precious products of Shensi in the western part of the Empire. As Shensi is an inland province in the very heart of China, these again must have been freshwater pearls."

${ }^{74}$ Streeter, op. cit., p. 63.

75 Ibid., Fp. 27 and 253 . 
In the "Tribute of $Y_{\ddot{u}}$ " (Shoo King, pt. iii., bk. i.), we find it stated that $Y$ ii received as tribute, "oysterpearls and fish" and "baskets full of deep azure silks," from the wild tribes about the river Hwae (or Hwai), between the Ilo and Keang rivers [Kiangsu, E. China]; and from the district of King-chow he received "strings of pearls that were not quite round," together with "baskets filled with deep azure and purple silken fabrics." it

Though seemingly acquainted with the local freshwater pearls at a very early period, it would appear that the marine pearl was unknown to the Chinese until about 400 13.C., when commercial intercourse between China and the west had become fully established.

According to Lacouperie, ${ }^{78}$ to whom we are inclebted for much valuable information concerning the pearl-trade in China, traders from the Indian Ocean (Erythrean Sea) arrived in the Gulf of Kiao-tchou (South Shantung) in the 7 th century I3.C. They established two colonies at this place and entered into trade relations with cities in Shantung, Shansi, Shensi, Kiangsu, Honan, and other states. Though pearls are not mentioned among the objects they introduced at this period, it is not a little curious to find that their sphere of influence coincides in a remarkable manner with the area where pearls are said to have been first known in China. This fact is significant and would seem to suggest that it was through the influence of these traders that the Chinese commenced to

7 See translation by Dr. James Legge, in "The Chinese Classics," 1865 , vol. iii., pt. i., pp. 107 and I 6.

i7 We have no means of ascertaining the source of the purple colour of the silks used as tribute, but the point is of interest in connection with the celebrated purple of the ancient Tyrians. Is it possible that this famous dye had been introduced already into China?

78 Lacouperie, op. cil. 
fish for the pearls contained in the mussels of the local rivers.

About the 5 th century H.C., Erythrean merchantmen began to use Hang-tchou Bay as a calling station, in addition to their earlier and more northern ports in the Gulf of Kiao-tchou, bringing with them large pearls from the Persian Gulf, and mother-of-pearl from the Indian Ocean. This latter commodity is stated to have been used to adorn the tomb of Duke Yii of Tsin, who died in 419 B.C. That the real pearl was a novelty at this period is gathered from the expressions used by writers of the $4^{\text {th }}$ century Meh-ti, Lieh-tze, Tsou-hien, and others. In some cases it is associated with the $\mathrm{Ye}-\mathrm{K}$ wang - the stone which shines at night, otherwise yakut ruby of Bardakshan. "And the name of Ming-gwet, a transfer and folketymology of the western word for it, shows moreover its western origin, most probably from the pearl fisheries of the Persian Gulf, not of Ceylon."79

From this time onwards pearls were among the staple articles imported into China by these same traders, though the latter had several times to change their stations and retreat southward owing to civil wars and the advance in power of the Chinese. They used Kwei-ki, near the present Ning-po, as their emporium until the Han Empire extended its sway there in 20 I B.C., when they made Tungyeh (present Fuhtchow of Fu-kiang) their station for a time, importing big pearls from the I'ersian Gulf. These were transhipped from there to Kwei-ki, which was a market for them. In I 87-I40 B.C., one Tchu-tchung was trading in pearls at Kwei-ki, some of the gems being of remarkably large size.

70 Lacouperie, op. cit., pp. I80- $[$ and $365 ;$ Ming-grwet, mod. Minsyzeh, shining moon.-Cf. Sanskrit, marakata; Greek, maiagdos; Latin, margarita; Persian marvid; etc., (fide Lacouperie). 
The rising of the Nan-Yueh kingdom attracted the foreign trade to the region of the present Canton, and on the conquest by the Nan-Yueh emperor of the country westward, in I79 13.C., the Hormuzian or Hwang-tchi (yellow-fingered) sea-traciers, ${ }^{80}$ as they were called, established themselves in the Island of Hainan, where they discovered pearls on the west coast and created the pearl fisheries of Tchu-yai, i.e. the coast of pearls (present Yai tchou). They traded with the Nan-Yueh through a station called Hop-pu, near the present Pakhoi, their goods reaching the principal market of Hêng shan, east of Nan-ning, in S.W. Kwangsi, on the Yii Kiang leading by the P'earl river to Canton.

In I IO B.C., these Hormuzian sea-traders once more removed their chief landing place, establishing it further south, on the west of Cape Cambodia, on the east side of the Gulf of Siam, in Tcham, the Zabai of Ptolemy. From here they traded l'ersian Gulf pearls to Kattigara and I Ioppu (near the present Pakhoi).

In the early Christian era, Cingalese traders seem to have taken over most of the trade with China. Among the articles of commerce mentioned in the Annals of the Eastern Ilan dynasty, in 69 A.D., are bright pearls and oyster-pearls from Ccylon. ${ }^{81}$

It is of some interest to note here that pearls are obtained at the present day in the Gulf of Siam from a small oyster with a thin shell. Kunz and Stevenson (op. cit., p. I 49) inform us that "the Siamese do not especially value pearls, attributing superstitious sentiments or ill

$\checkmark$ Names derived from IIormuzia, near the l'ersian Gulf, and from the use of henna to dye their fingers.

s1 Lacouperie, op. cit., p. 252, and p. 255 note II 12 ; Krvang-tchu, i.e. bright pearls, different in name from the Ming-gwet pearls of the Persian Gulf; pang-tchu, oyster-pearls (? pearl-oyster shells). 
luck to them." They further remark: "Some fine old specimens of marquetry in which these [pearl] shells were used exists in the 13uddhist temples at Bangkok. This art of inlaying is almost lost to-day among the Siamese, and there is said to be only one man in the king's palace who. can lay any claims to proficiency in working mother-ofpearl shell."

In China during the Han dynasty, De Groot informs us $^{82}$ "pearls also occupied a place among the objects which were introduced into the mouth of the dead. At least it is stated in the funeral ritual for the Sovereigns of this house that 'their mouths were filled with rice, and pearls and jade stone were put therein, in accordance with the established ceremonial usages.' And the 'Poh hu thung i,' a well-known work professedly written in the first century, says: 'On stuffing the mouth of the Son of Hcaven with rice, they put jade therein; in the case of a feudal lord they introduce pearls, in that of a Great officer and so clownwards, as also in that of orclinary officials, cowries are used to this end.'"

The free use of pearls and other precious objects in comection with the ritual of the dead, is said to be founded on a desire to procure light for the soul, that it may be conducted safely along its paths in the dark beyond. 13ut the chief object of this practice, it would appear, is to save the body from a speedy decay. ${ }^{83}$

The custom of placing articles of value in the mouth of the dead is analogous to similar practices widely prevalent in other parts of the world. It is well known to have obtained among the Greeks, the Romans, the Hindus and the ancient Mexican emperors. ${ }^{\sharp t}$

$\because 2$ De Groot, "The Religious System of China," Leyden. 1892, vol. i., p. 277, the present book].

s: Ibid., p. 279, footnote. 
Reference has already been made (supra p. 89) to the placing of pearls in the mouths of deceased Hindus; a similar custom was practised by the "mound builders" of the Mississippi valley (see p. I I 4).

Pearls are frequently alluded to in Chinese literature as the depositories of Y Yang matter, and as such ranked among the bearers of vitality. Medical works declare that they can ensure and facilitate the procreation of children, and these same books say that pills made of pearls mixed with the blood from the comb of a cock and inserted in the eyes of a person who has suddenly expired, or lost his speech, can be useful in recalling the person to life. ${ }^{n j}$

The valves of Unio tientsinensis, the Ko-fen of the Chinese, are used by these people as a powder in medicine, and occasionally as one of the ingredients of pills, as a substitute for the pearls from the marine pearl-oyster. On account of the costliness of pearls from the latter source, pills and powders made from them are said to possess marvellous powers of cure, and are even used in the treatment of small-pox..$^{86}$

It would seem that in China, and in other oriental countries, a distinction is made in the therapeutic properties of so-called "virgin" pearls and of those pierced or bored for stringing. One Chinese natural history states that bored pearls will not serve for medicine, for which unpierced ones should be used. ${ }^{87}$

Legends of "lightning pearls," "pearls shining during the night," "pearls lighting like the moon," inter alia, are current in considerable numbers in the native litera-

s 5 Ibid, pp. 217 and 277.

8 is Lovell, of. iil., pp. 75 and ro2, quoting J. O. Desbeaux, "Essai sul" La l'harmacie et la Matière Médicale des Chinois.."

si Kunz and Stevenson, op. cit., pp. jos-9. 
ture. Allusions are made to pearls so brilliant that they were visible at a distance of nearly a thousand yards. Rice, it is alleged, conld be cooked by the light from them. One found about the beginning of the Christian era, near Yangchow-fu, province of Kiang-su, was reported so lustrous as to be visible in the dark for a distance of three miles."

The "Ch'êng I'ii K'ao," compiled by Ch'iu Chin, alizs Wên Chuang, a famous scholar of the Ming dynasty (born A.1). 14I9; died I495), ${ }^{89}$ contains several interesting references to pearls, some of the most curious being that "pearls can ward off the calamity of fire" ; "the mermaid wept tears that became pearls"; "Ma Ku threw grains of rice which became pearls"; and: "He who cut open his stomach to hide the pearl loved mammon more than his life." T'ai Tsung of the T'ang dynasty (A.D. 627-650), when warning his minister against covetousness, and licentiousness, said that those who were guilty of these offences were as worthy of ridicule as the merchant from Syria, who opened his stomach to hide the pearl. One Chinese work states that when the whale dies, its eyes are changed into pearls. ${ }^{90}$

Regarding the origin of pearls many fantistic theories are to be found in ancient Chinese literature. By some writers they are credited as originating in the brain of the fabled dragon, and frequent allusions are made to pearls under the throats and in the mouths of these creatures. In China and Japan, as well as in India, pearls were considered to be in the special possession of dragon-

s De Grool, op. cil., p. 277 ; Kunz and Stevenson, op. cit, p. 5.

so See translation by J. HI. Stewart I ockhart in "A Manual of Chinese ?urtations," Hong Kong, and Ed., I903.

20 Tbidh, pp. 395 and 402. 
shaped sea-gods, or Nagas. ${ }^{91}$ These mythological creatures - gods of water, thunder, rain, and wind-were believed to have their abode in certain ponds and rivers, and especially in splendid palaces at the bottom of the sea. Hence we find many curious stories in the literature of these countries. In Oldham's work "The Sun and the Serpent" (London, 1905, p. 6r), allusion is made to the Nagas of southern India living under the sea in a place called the land of gems." Legge, in the "Sacred Books of the East" (vol. xl., p. 2II), quotes a legend from Shuangtze, a writer of the $4^{\text {th }}$ century B.C., who says : "Near the Ho river there was a poor man, who supported his family by weaving rushes. His son, when diving in a deep pool, found a pearl worth a thousand ounces of silver. The father said: 'Bring a stone and beat it to pieces, a pearl of this value must have been in a pool nine khung deep and under the chin of the black dragon. That you were able to get it must have been owing to your having found him asleep. Let him awake, and the consequences will not be small." account of the Lien-chan district, in the Canton province (Kwantung), states: "In the sea there is an island with a lake, into which the barbarous natives dive for shells; some years they are abundant, and in others scarce. There is a myth amongst the fishermen of a walled city at the bottom, guarded by monsters, containing pearls of large size and splendour, but which cannot be obtained for the guards ; small ones, growing outside the city walls like grass, being the only ones obtainable." ".t

${ }^{2}$ On the subject of the Chinese dragon, see Dr. M. W. rle Visser, "The Dragon in China and Japan," Amsterdam, I913.

${ }^{2}$ W. I. Perry, op. cit., p. $1 \mathrm{I}$, quoting Oldham.

"): Kunz and Stevenson, op. cit., p. 302, quoting Legge.

o* F. Hague, "On the Natural and Artificial production of Pearls in China," Journ. Roy. Asiat. Soc, G. B. E I., vol. xvi., pt. 2, Art. xv., p. 28 r. 
All these myths seem to be modifications of the old idea of social relations between pearl-oysters and sharks, or of the curious story quoted by Pliny (Bk. ix., ch. 55) from Megasthenes that pearl-oysters lived in communities, just like swarms of bees, each of them being governed by one remarkable for its size and great age (or splendour), and which at the same time possessed marvellous skill in keeping its subjects out of danger; the divers, it is said, took especial care to find these, so that the others might easily be taken.

The art of artificial pearl-making seems to have been. practised by the Chinese for several centuries. Mr. F. Hague, British Consul at Ningpo, informs us that "there is a note that at the commencement of the seventh century, pearls were made of a composition or medicine. The art may have been lost, or it may be the same as that now employed at, and which originated at, Canton." "ns In conjunction with Dr. Mc Gowan, an Imerican physician resident at Ningpo, the method pursued by the Chinese with the "Mussel-pearl" was carefully investigated, and excellent accounts of this interesting inclustry have been published. $^{96}$ The practice of the art is carried on in two villages near the city of Teht-sing (Titsin) in the northern part of Chihkiang (Chekiang), in a silk-producing region. In May or June, quantities of large freshwater mussels (Dipsas plicatus) are brought from the $T \bar{a} h \bar{u}$, a lake in Kiang-su, some thirty miles distant, and after a few days' respite in bamboo cages in water, various matrices are introduced between the animal and the shell by means of a bifurcated bamboo stick. After a sufficient number has been treated they are placed in canals, pools, and streams. In about a year the matrices bccome incrusted

जs Tbid., p. 282.

00 Ibid., [p. 280-4; and McGowan, Journ. of Soc. of -4 rts, ii., pp. 72-5. 
with the pearly nacre, and the mussels are taken out of the water, and the "pearls" detached by a sharp knife. The matrices used vary in form and substance, the most common being pellets of mud. Another class consists of small images, especially of Buddha, in the usual sitting position, or sometimes of a fish; they are made of lead, cast very thin. The invention of the art is attributed to a native of the place, named le-jin-yang, to whom a temple has been erected, in which divine honours are paid to his image. IJe is said to have lived about A.D. I $200-$ I 300. The topography of Chinkiang mentions a pearl sent to Court in 490 A.D., which resembled Buddha, being three inches in size. The resemblance, however, may have been fanciful; the "pearls" now made are but half-an-inch long.

Other writers have given similar accounts of this curicus industry, but the most remarkable is that related by Mary Roberts in her little book on the "Popular History of the Mollusca" (1851, pp. 275-6). She tells us that in the possession of Sir Joseph Banks were "several Chinese Chame [? Unio], in the shells of which were contained bits of iron wire, covered with a substance of a pearly nature. These wires had evidently once been sharp, and it seemed as if the mollusks, anxious to secure themselves against the intrusion of such unvelcome visitors, had encrusted, and thus rendered blunt, the points with which they came in contact." She concludes by remarking: "may not, therefore, the process employed in past ages be still practised? And are we not authorized in conjecturing that these bits of iron, which probably had slipped from the hands of the Chinese workmen, and remained in the animal, resembled the spikes noticed by Philostratus as being used by the ancient people who inhabited the banks of the Red Sea, for the purpose of 
pricking mussels?" In view of the fact that the Chinese retain, with few alterations, the arts and customs of their ancestors, these suggestions are not at all improbable. In this connection it will be of interest to notice the particular skill possessed by the Chinese in drilling holes in pearls. This, as pointed out by Lacouperie (op. cit., p. 24I, note 1037 ), they may have learned from the pearltraders of Hormuz who were celebrated for their ability in this respect, and to whom Ceylon pearls were sent for that purpose.

At what period pearls were first appreciated in Japan is not known. The occurrence of pearls on the coasts of that country is repeatedly alluded to in ancient works relating to Japan. According to Kumz and Steveuson, ${ }^{9 \pi}$ they are mentioned in the Nihonki, of the eighth century, the oldest Japanese history. Dr. T. Nishikawa also states they were used in Japan for ornamental purposes more than a thousand years ago. Large pearls derived from the abalone, or Haliotis, are found in images of Buddha made in 300 A.I). Freshwater pearls, from Dipsas and Unio, appear to have been also used." In Marco Polo's time these people still carried on the Chinese custom of placing pearls in the mouth of the dead. WVe learn from this famous traveller that "in the island of Chipan-gu (the kingdom of Japan), the Chinese Jih-păn-Kwē, rosecoloured pearls were abundant, and quite as valuable as the white ones," that "some of the dead were buried and others were burnt," and "when a boily was burnt they put one of the rose-coloured pearls in the inouth, for such is their custom." These coloured pearls were doubtless derived from conch-shells.

$\because$ Kunz and Stevenson, op. cil., p. 147.

os Thid., P. +14 .

" Colonel IIenry Yule, C.B.. "The Book of Ser Marco Polo" (Bonk iii., ch. ii.), vol. ii., p. 200. 
In I727, Kaempfer noted that pearls were obtained by the Japanese from small sorts of oyster's, called akoja, not unlike the Persian pearl-oyster; also from the yellow snail shell and from the taira gai (Placuna), and especially from the awabi or abalone (Haliotis). ${ }^{100}$.

From narratives of China by the Jesuits, there appears to be some evidence of a former pearl fishery in the neighbourhood of Saghalin Island, but the intelligent navigator, M. de la l'erouse, expressed much doubt on this point. He acknowledged that his people found oysters that contained pearls, and admitted it possible that a few families of fishermen may have united together for the purpose of fishing for pearls, in order to exchange them for nankeens and other articles of commerce from China; but be did not observe that any of the natives of the places at which he touched on the coast estimated this kind of pearl more than common beads. ${ }^{101}$ There seems to be, however, ample evidence of old-established pearl-fisheries in this region, judging from the various records summarized by Von Hessling in 1859 (op. cit., pp. 20I-4). In Manchuria, he tells us, pearis have been fished, from the oldest time to the present day, in the streams which flow into the Songari, a tributary of the Amur. Witsen, writing in 1705 , mentions the pearls from the Gan, a tributary of the Amur, and also from the islands of the Amur at the junction of the Skilka and Argun. Pearl-fisheries were established here by the Russians nearly two centuries ago. Pearls are finer and more plentiful, says Hessling, in southern Manchuria, especially in Lake Heikow or Hing-tchou-men, "Black Lake" or "Gate of Precious Gems," where they have been fished for ages for the account of the Emperor of China.

jon Kunz and Stevenson, op. al., pp. I47-8.

101 G. A. Cooke, "System of Universal Geomraphy," vol, i. (I80I), p. 574 . 
Cooke, in I So I (op. cit., vol. i., p. 425), also speaks of the Manchurian pearls as an article of commerce, together with a plant called ginseng. ${ }^{102}$

In Kamtchatka, pearl fisheries are recorded from the south end of the peninsula (Lopatka), and from Nijni Kamtchatsk, on the east coast: these arc possibly freshwater fisheries. Pearls have also been found at the Kurile Islands, and at Lebäshja, on the south coast of the Sea of Okhotsk, but these were probably from sea shells, Iytilus edulis or ITachurra costatu, as no Lnios are recorded from these places, ${ }^{103}$

An interesting reference to very early intercourse between north-eastern Asia and China is quoted by I acour,crie in his work already cited (p. 353, note 195). It appears that the "Shih $y$ hi" (kiv. 5) mentions a mission of a Nêlê country in I93 lic. . from beyond fisang (Saghalin). Dr. G. Schlegel identifies this with the country of the Tchuktchis, in which Iacouperie concurs. No information is given as to the object of the mission, but it seems probable that it was for the purposes of trade. If so, it is not unlikely that the envoys would learn of the appreciation of the pearl by the Chinesewho were well acquainted with the gem by this dateand benefiting by the knowledge, they might have instituted pearl fisheries on their own account. The present

102 Ginseng (Pantat sithinsels $)$ is a native of Tartary and Northern China, growing at one time abundantly in Manchuria, but its great use in China has caused it to become scarce. It in a low lrerbaceous plant with forked roots, which the Chinese imagine resembles the human form, and is supposed to ward off all diseases. It is slightly litter and aromatic, lut is not of much repute with European doctors. Panax quingufolia, a native of North America, is somelimes substituted for it (Smith, "I)omestic Botany," I87 1, p. 362). Ginseng is used by the Indians of Canada, Virginia, South Carolina, elc, along with suake root. (Cooke, op.cil, ii., lp. 32, 69 and 79 ). 
pearl fisheries in this region, detailed above, may be survivals of an ancient industry.

In northern Siberia, according to Witsen, pearls were found in the waters around Mangasea on the Turuchan, and a manuscript in the Moscow College notes that they were found in the river Tunguska which flows into the Yenisei. Witsen also refers to their occurrence in the rivers and streams of Irkutsk and Onon; Pallas speaks of the Ilim, a tributary of the Angara, as another river where they occur. ${ }^{104}$

Kunz and Stevenson (op.cit. p. 410) mention an interesting discovery (made in southern Siberia in the time of Peter the Great) of a broken gold ring with a roughlycut turquoise and two pendants, each set with two pearls separated by a garnet. This object is thought to belong to the second century before Christ. ${ }^{105}$

In the l'acific Islands pearls and pearl-shell seem to have been appreciated for centuries. Among the native ornaments noted by Captain Cook at Tahiti were feathers, shells and pearls; but the latter were worn chiefly by the women. In the Harquesas Islands, plates of mother-ofpearl decorated the principal head-dress of the natives, while ornaments consisting chiefly of pearl-shell were seen in Toobouai; Friendly Islands; Mangeea Island; New Caledonia; New Zealand; etc. The pearl-shell was also found to be employed in the construction of fish-hooks in many of the islands visited by early navigators. ${ }^{106}$

Since Cook's time a consiclerable literature has accumulated on the subject of these pearl-shell fish-hooks. Hedley, in his "Ethnology of Funafuti" gives a most $10 \pm$ Ihill., p. $20 \mathrm{r}$.

105 Given as second century A.D. un plate figuring the specimcll.

10 G. A. Cooke, op. (16, i. (1801), pp. 32, 36, 62, 6:, 84, 85, IoI, I05, II 3 , I 3 I, I78, 273 and 318 .

107 Mem. Aust. Mhus, iii, pp. 266 et neq. 
interesting account of their manufacture and distribution in the various islands of the Pacific. The pearl-shell. hooks he remarks, "represented to the Ellice Islanders of past generations their most valued treasures. Apart from their intrinsic worth they acquired, as conveying a maximum of wealth in a minimum of space, an artificial value approximating to the coins of more advanced civilisations." They were appreciated to such an extent that they were frequently offered to the gods, and on Vaitupu, of Tracey Island, where the dead were buried inside the houses, they were deposited in the grave with the body, accompanied by necklaces and other ornaments. In former times messages were transmitted from atoll to atoll by means of pearl fish-hooks attached to the wings of Frigate-birds. ${ }^{108}$

According to Hedley the value of these hooks in the Ellice Archipelago was heightened by the rarity and inaccessibility of the shell (Avicula cumingii) from which they are made, the supply being principally from a bed in the Lagoon of Nukulailai. This type of hook, he informs us, is universal throughout the. Pacific, being used alike by Melanesians, Polynesians, and Micronesians. Examples are recorded from Manihiki and Mortlock Islands, the Gilbert and Hawaiian Groups, Danger Island, Strong's Island, Tahiti, Tonga, Samoa, and the Solomons; also from the Carolines, the Marshalls, and the Marquesas. In New Zealand, owing to the absence of the true pearlshell, the Maories made use of "pawa" (Haliotis iris) as a substitute for the flashing nacre of the Avicule.

Turner ${ }^{109}$ informs us that at Nukulailai offerings consisting of pearl-shell were taken to the temple, and at

108 Hedley, op. cit., p. 266 ; see also pp. 47, 53 and 59 ; and G. Turner, "Samoa, etc." London, 1884, gp. 282 and 284 .

as: G. Turner, op.cit. pp. 280 and 288 . 
Nanomana similar offerings were suspended under the altars of the principal gods Foelangi and Maumau.

Among the Torres Straits Islanders pearl-shelis are trimmed and worn as breast-ornaments, or carved into beautiful crescentic and other shapes to be worn as pendants either on the chest or in the ears. ${ }^{110}$

They also appear to have been used in mummification, as Dr. Elliot Smith has recently referred to the case of a Torres Straits mummy having the eye-sockets filled with a gum or resinous substance in which narrow oval pieces of mother-of-pearl were embedded. ${ }^{111}$

Crescent-shaped plates of pearl-shell are also in common use as breast ornaments in British New Guinea and the Solomon Islands, and the same shell $i$ s used as an inlay to decorate the native canoes. ${ }^{112}$

In the Sandwich Islands the eyes of idols were noticed by Captain Cook to be made from large pearl oysters, with a black nut fixed in the centre.

Ellis, in his "Polynesian. Researches," ${ }^{113}$ gives us a Jucid description of the curious dress worn in Tahiti at death ceremonies of chiefs. This consisted of a cap of thick native cloth fitted close to the head; in front were two large broad mother-of-pearl shells, covering the face like a mask, with one small aperture through which the wearer could look. Attached to this head-dress was a beautiful kind of network composed of small pieces of brilliant mother-of-pearl shell, each being about an inch or an inch and a half long, and less than a quarter of an

110 A. C. Haddon, "Reports of the Cambridge Anthropological Expedition to Torres Straits," vol. iv., 19r2, pp. 40-45.

111 "The Migrations of Early Culture" (Manchester, 1915), p. 93.

112 Haddon, op. cit., iv., p. 43; and H. B. Guppy, "The Solomon Islands and their Natives," London, 1887, pp. I 3 I and I46-7.

113 Vol. i., pp. 412-3. 
inch wide Erery piece was fincly polished, and reduced to the thinness of a card. Small perforations were made at each corner to enable the pieces to be threaded together. The labour in making this, Ellis says, must have been excessive, as so many hundred pieces of pearlshell had to be cut, ground down, polished, and perforated, without iron tools. Its manufacture was regarded as a sacred work.

learl-oyster shells set in whales' teeth are considered to be the most valuable ornament that a Fijian possesses; he wears it at dances hanging on his breast, and he is forbidden by the chiefs to sell it. ${ }^{11-}$

It has been asserted by some historians that pearls were unknown in the New Norld in pre-Columbian times, but we have evidence that ages prior to the discovery of America by Columbus the ancient inhabitants fully appreciated these gems. Quantities of pearls, in many. cases perforated for stringing as nccklaces, etc., have been discovered in the mounds erected by the ancient population of the Mississippi Valley. Professor Putnam ${ }^{\mathrm{u}}$ records that in excavating the mounds near Madisonville, Indiana, not less than fifty thousand pearls were found, most of them pierced and injured by heat. Squier and Davis ${ }^{116}$ found them on the hearths of five distinct groups of mounds in Ohio, and sometimes in such numbers that they could be gathered by the hundred. In addition to the pearls, quantities of other interesting objects were met with which indicate the existence of inter-tribal commerce on an extensive scale at a remote period. The

11 II. X. Moseley, "Notes by a Naturalist on IH.M.S. Challenger," IS92. p. 286 .

115 Iroc Amer. Assac, Atä́. Siz., $18 S_{4}$.

11: Squier and Davis, "Ancient Monuments of the Mississippi Valley," Washingtom, 1848. 
pearls were originally thought to have been brought from fisheries in southern waters, but are now considered as having been derived, partly, if not entirely, from the freshwater mussels (Unio) so abundant in the rivers of the region of the mounds. W. C. Mills, in his "Explorations of the Edwin Harness Mound,"17 also speaks of the large quantities of freshwater pearls made into beads which were found in every section of the Harness Mound. In one instance more than two thousand of these beads were found with one burial. They are all small, some being perfectly round. Several hundred were obtained ranging in diameter from a quarter to half an inch. In some cases the large pearls had been flattened on one side and set in copper; in others, the pearls were often flattened and pierced with two holes, as if for attachment to fabrics, etc. The most curious discovery, however, in this mound was that of imitation pearls made of clay, and apparently modelled from real ones. These clay imitations appear to have been coated with mica and then burned so as to preserve a pearly appearance. This remarkable discovery is of great interest as recalling the clay pellets used by the Chinese in their artificial pearl-making industry.

At the Gartner Mound, in the same region, a shell gorget was found with a hole cut in the centre and a pearl cut and mounted to fill it. ${ }^{118}$ And gorgets and crescents made from fresh-water pearl-shells were by no means uncommon in this and other Ohio mounds."

In his description of "The Seip Mound," 119 situated within the largest prehistoric earthworks of the Paint

117 Ohio Archaol. and Fist. Quart., vol. xvi., no. 2, rgo7.

118 Mills, "Explorations of the Gartner Mound and Village Site," Ohịo Arch. and Hist. Quant., vol. xiii., no. 2, I904.

118 Mills, "The Seip Mound," Putnam Anniversary Volume. N.Y., I909, pp. IIO, II 4 and I22. 
Creek valley of Ohio, this same authority refers to other occurrences of pearls including a beautiful string of these gems in a good state of preservation from one burial ; also to the discovery of bears' teeth set with pearls in what appeared to be sacred shrines for the dead.

In addition to the archæologists cited above, other noted authorities, including IV. K. Moorehead, have examined the mounds of the Ohio region, and have met with abundant evidence, both in the burial and in the altar mounds, of the ancient appreciation of pearls. ${ }^{120}$

When found in burial mounds with skeletons, the pearls are usually at the wrists or ankles, or about the neck, or in the mouth, the latter recalling forcibly the Hindu and Chinese custom of placing pearls in the mouth of the dead (supra pp. 89 and 100).

In the case of the altar mounds, there is evidence of a different procedure. Instead of a burial, there was a great funeral sacrifice in honour of some distinguished person, in which numerous treasures, including quantities of pearls, were consumed, or meant to be.

It would seem that though the number of pearls encountered in the mounds of the Ohio region is very great, the graves which contain them are relatively very few. They seem to have been buried only with persons of special distinction, probably either chiefs or eminent medicine men: this preferential use of pearls, it may be observed, was also found in Asiatic countries.

In the mounds of Illinois pearls have also been met with associated with skeletons of Indians. Dr. J. F. Snyder records the discovery of large canine teeth of the bear, set with pearls, at the base of a large mound which he opened in 1895 , in Brown County, on the west side

120 An excellent summary of the work of these authorities is given by Kunz and Stevenson (op. cit., especially in Chap. xvii.) 
Sof the Illinois River. Near by were also the remains of a necklace composed of alternate pearls and bone beads. The McEvers Mound in Montezuma, Pike Co., Illinois, also yielded, according to D. I. Bushnell, the excavator, a group of forty-five pearls, including one of beautiful lustre weighing fifty-two grains. ${ }^{121}$

The use of pearls as ornaments, and for depositing with the remains of persons of distinction, was also customary among the Indian tribes of Virginia. The accounts of early explorers and colonists furnish us with many details as regards the burial of pearls with the dead and their use in religious rites. The first English colonists found the Indians of Virginia esteeming pearls among their favourite treasures and ornaments. An excellent account of these Indians is given by Charles C. Willoughby in the "American Anthropologist" (vol. ix., I907). This article is of great interest as dealing with the habits and customs of the tribes occupying tidewater Virginia at the time of the first colonization. The Indians, a branch of the Algonquian stock, formed a powerful confederacy under Powhatan comprising some thirty tribes. To the greater chiefs tribute was paid in pearls, copper, beads, skins, etc. Pearls were also used to adorn the native clothing, as well as for necklaces and ear-pendants. Strachey, an early explorer, reports having seen "manie chaynes and braceletts (of pearls) worne by the people, and wee have found plentie of them in the sepulchers of their kings, though discoloured by burning the oysters in the fier, and deformed by grosse boring." The writings of this and other explorers give curious accounts and descriptions of the "temples" within which, in a sort of sanctuary or "chancel," were kept the dried bodies of deceased chiefs, and an image of the god, called Okee, made in the shape

$121 \mathrm{Kunz}$ and Stevenson, op. cit., p. 509. 
of a man, "all black, dressed with chaynes of perle." The process of preserving the remains of the chiefs is described as follows: "After the body had been disemboweled, the skin was laid back and the flesh was cut away from the bones. When this operation was completed, the skeleton, held together by its ligaments, was again inclosed in the skin, and stuffed with white sand, or with "pearle, copper, beads, and such trash sowed in a skynne.' It was then dressed in fine skins and adorned with all sorts of valuables, including strings of pearls and beads. The same kinds of treasures were also deposited in a basket at the feet of the mummy." "1:

The chroniclers of De Soto's expedition to Florida in r 539, speak of almost fabulous quantities of pearls in the possession of the Indians of the parts traversed by them. One Portuguese narrator says, "they obtained fourteen bushels of pearls" from a certain sepulchre, and it is stated that a common foot soldier had "a linen bag, in which were six pounds of pearls," and pearls are elsewhere spoken of that are " as large as filberts." Garcillasso de la Vega says "while de Soto sojourned in the province of Ichiaha the cacique visited him one day and gave him a string of pearls about two fathoms long. This present might have been a valuable one if the pearls had not been pierced, for they were all of equal size and as large as hazelnuts." "

"As in Cleopatra's time in Egypt," says Streeter, ${ }^{124}$ "so in Florida, the graves of the kings were decorated with pearls. Soto's soldiers found in one of their temples

1‥ Ilid., pp. 486-8.

12 s Stearn, Reft. U.S. Nat, AYus, , I887 (1889), pt. ii., p. 279, quoting Irving's "Conquest of Florida"; see also Grace King, "De Soto and his men in the Land of Florida," New York, 1914, Pp. I 36 -I43, etc.

$1 \because$ Streeter, op. cil., pp. 45-6. 
great wooden coffins, in which the dead lay embalmed; and beside them were small baskets full of pearls. The temple of Tolomecco, however, was the richest in pearls ; its high walls and roof were of mother-of-pearl, while strings of pearls and plumes of feathers hung round the walls; over the coffins of their kings hung their shields, crowned with pearls, and in the centre of the temple stood vases full of costly pearls."

Though the various accounts relating to the abundance of pearls in Florida are probably somewhat exaggerated, there seems sufficient evidence to prove that pearls of some value were in the possession of the wealthier tribes. That they were met with in some numbers in graves seems also to be a reliable statement. ${ }^{1 * 5}$

As to the source of these pearls, most of the narratives refer to them as coming from the coast of the South Sea or Gulf of Mexico. While possibly this was the case with some of the pearls, it is more probable that the majority came from the freshwater shells (Unios) of the inland lakes and rivers.

In Alabama, pearls pierced for stringing have been found in several of the mounds at Moundville by Clarence B. Moore, along with a sheet-copper pendant bearing a perforated pearl nearly $7 \mathrm{~mm}$. in diameter, and an elliptical gorget of sheet-copper decorated with a pearl. ${ }^{1.6}$ Perforated pearl beads have been also found in the Etowah Mound, located in Barton County, Georgia. ${ }^{1 \cdot 27}$,

At the pre-Columbian capital of Copan, in Western Honduras, evidences have been met with pointing to a very early use of pearls. G. B. Gordon ${ }^{128}$ tells us that in pp. 252-259).

125 This question is fully discussed by kunz and Stevenson (op. cit.,

120 Kunz and Sterenson, op. cit., p. 493.

127 W. K. Moorehead, "Prehistoric Implements," N. Y., I900, p. 376.

128 G. B. Gordon, "The Mysterious City of IIonduras," The Century Magasizte, vol. iv., f. 4I7. 
exploring a number of isolated tombs beneath the parcment of courtyards and under the foundations of houses at this city, human remains were found associated with various articles of use and adornment. "The beads, earornaments, medallions, and a variety of other ornaments, usually of jadeite," Gordon remarks, "exhibit an extraordinary degree of skill in the art of cutting and polishing stones, while the pearls and trinkets carved from shell must have been obtained by trade or by journeys to the coast." Thomas Gann, of I Iucatan, also states that "ornaments such as beads, gorgets, and ear-pendants, made from the pearly shell of both the oyster and the conch, are of common occurrence in many sepulchral mounds in British Honduras and I'ucatan." "

In Guatemala no pearls appear to have been observed in the pre-Columbian graves, but marine shells, whole, and elaborated in connection with jadeite beads have been found. ${ }^{130}$

On the Pacific coast of Mexico, and especially along the coast of Lower California, quite extensive pearlfisheries are prosecuted. The fisheries on the Mexican coast appear to have been in existence for centuries. European knowledge of these resources dates from the conquest of Mexico by Cortés about I $_{522}$. Native chiefs were found living in primitive huts along the sea-shore, with quantities of beautiful pearls lying around, and from a tribe near the present site of Hermosillo, in the State of Sonora, Cortés secured quantities of the gems. ${ }^{131}$

Pearls were highly appreciated by the Aztec kings, and the gems were employed to decorate statues of the gods and their temples, as in India. The temple in which

1 9 Kunz and Stevenson, of. cit, p. 5 II.

130 Jbid., p. 51 I.

131 Kunz and Stevenson, op. cit., p. $2+$ t. 
Montezuma used to pray at night, is said to have had walls of beaten silver and gold, decorated with pearls and precious stones. ${ }^{132}$ Humboldt refers to a statue of a Mexican priestess in basalt, whose head-dress is ornamented with pearls. ${ }^{193}$ Bateman ${ }^{13 \pm}$ likewise mentions an ancient Mexican horned head-dress, inlaid in mosaic with turquoise, malachite, coral (?), and mother-of-pearl. Pearl-shell also appears to have been used as an inlay in the Mexican mosaic masks in the British Museum, which are preColumbian in origin. One of these, a plain mask, is of special interest as the eyes are of mother-of-pear]. ${ }^{135}$

Mrs. Zelia Nuttall, in a letter to Kunz and Steven-. son, ${ }^{136}$ writes "that pearls are not mentioned either as articles of tribute or of decoration in ancient Mexican codices; possibly a lack of fine, hard instruments with which to drill holes in pearls may have caused them to be comparatively little used in personal adornment. Neither do they appear to have been found incrusted in prehistoric objects, and we have no written evidence of their having been used in this way. We do not know of any instances of the wearing of pearls by the Indian women; but the women of the higher classes used to wear them profusely, more especially clrop-earrings and pendants."

W. H. Holmes, ${ }^{197}$ quoting from Davis' "Spanish Conquest of New Mexico," says: "In travelling north along the west coast of Mexico, the Friar Niza encountered Indians who wore many large shells of mother-of-pearl about their necks, and farther up towards Cibola, the

\footnotetext{
15: Streeter, op. cil., p. 45 ; אunz and Stevenson, op. cit., p. 23.

133 Humboldt, op. cit., i., p. rg1.

134 Bateman, "Catalogue of Antiquities," Bakewell, I855, p. 236.

135 Kunz and Stevenson, op. cit., p. 5 ro.

1s : Kbid., p. 433.

${ }_{137}$ W. H. IIolmes, "Art in Shell of the Ancient Americans." Second" Anmual heport of the Burean of Ethnology, Washington, I883, p. 256.
} 
inhabitants wore pearl shells upon their. forcheads." These facts are of interest as recalling the identical use of pearl shell in some of the Pacific Islands-Torres Straits Islands, Solomon Islands, etc.,-and in Ancient Egypt (supra p. 74).

According to the reports of travellers, the natives of Mexico, in the I 8 th century, still appreciated pearls, using them along with other jewels to adorn their noses, lips, ears, necks and arms. ${ }^{138}$

On the coast of Venezuela extensive pearl fisheries have been carried on since before the time of Columbus. On entering the Gulf of Paria, in 1498 , this voyager found the natives in possession of numerous pearls which they were wearing on their necks and wrists. They were also seen engaged in pearl fishing by the Spaniards, and it is curious to note that the views of the Indians regarding the origin of the gems were identical with those which obtained for ages in the Old World. They regarded them as congealed dewdrops, which had been caught by the gaping oysters. ${ }^{1: 4}$

Another famous American pearl fishery is that of the Gulf of Panama, referred to by many early Spanish writers. The pearl resources of this region were first made known by Balboa's immortal journey in 1513 across the Isthmus of Panama to the Pacific. Having reached the Pacific, Balboa proceeded along the coast and found the Indians in possession of gold and pearls, the latter being used to decorate their paddles. The pearl fishery appeared to be the principal source of income and wealth of the Indian chiefs. ${ }^{140}$

Among the pre-Columbian antiquities found in Ecuador associated with burials was a little box or receptacle

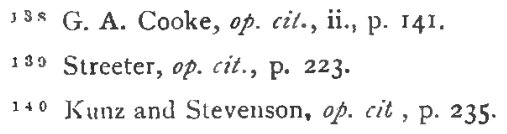


cut from a Cassis shell, the cover of which was a fragment of the valve of the pearl-oyster. ${ }^{141}$ This and other discoveries of pearls in that country by the same investigator point to the existence of pearl fisheries on this coast many centuries ago. It is reported that Manta, in the Province of Manabi, is the place where the Incas obtained the splendid gems found in the temples and palaces of l'eru by the Spaniards. ${ }^{1+2}$

The Incas of Peru held a curious belief concerning pearls; they regarded them as the "eggs" of the pearlproducing shell-fish. ${ }^{1+3}$

The artificial eyes of their mummies have been spoken of as pearls, but, according to $\mathrm{T}$ schudi, they are the dried eyes of the cuttle-fish (Loligo gigas). ${ }^{14+}$

Rivero and Tschudi ${ }^{1+5}$ inform us that the P'eruvians were accustomed to omament their textiles by sewing upon them leaves of gold and silver, or small pieces of mother-of-pearl, etc.; and in speaking of the Huaca of Misa, they say that a stone idol, with mother-of-pearl, was formerly met with here, along with mummies, cloths, pieces of gold and silver, etc.

Much further information could be given concerning the use of pearls and pearl-shell, but enough evidence has been collected to demonstrate the nature and extent of the ideas concerning them. However, mention might be

$1+1$ M. II. Saville, "Antiquities of Manabi, Ecuadlor," Contrilutions to South American Archeology, N. Y., 1910, vol. ii., p. I77.

149 Kunz and Stevenson, op. cit., p. 282.

I+8 W. J. Dakin, "Pearls," Cambridge, I9I3, p. 8.

1+4 Tryon, "Struclural and Systematic Conchology," vol. ii., $188_{3}$, p. 24. Cuttle-fish eyes are strung, as pearls for necklaces, on the shoses of Sicily and Naples; and the natives of the Sandwich Islands liave inposed them on the Russians as pearls. Johnston, op. cit., p. 62 foutnote.

i 4 I. L. Rivero and J. J. von Tschudi," Peruvian Antiquilies," New York and Loncion, 1857, pp. 224 and 266 (Translation by F. L. J Jawks). 
made of an interesting reference to the use of pearl-shell among the Indians of southern Alaska.

In his description of Port des Francais, the celebrated navigator, M. de la l'erouse, remarks on the ability of the Indians of this neighbourhood to inlay boxes of elegant form with mother-of-pearl. Unfortunately, he does not state whether the true pearl-shell was employed, or that of the abalone (Haliotis). This, however, is not of very great importance, as the point of chief interest is the fact that the use of the pearl-shell for inlay purposes is strongly suggestive of Asiatic influence. Other details, given by l'erouse, concerning the many curious customs of these same people, such as 'platform burials,' the 'special preservation of the head of the deceased and cremation of the body,' etc., provide equally suggestive evidence of this. ${ }^{146}$

The Haliotis, which also yields good pearls, was applied to many varied uses by other savage peoples on the Pacific coast of America, especially in California, where these pearly shells have been found in great numbers in the burial places of the ancient tribes. Putnam records the discovery of several objects inlaid with Haliotis shell in graves on the islands of Santa Catalina and of Santa Cruz, the pieces of shell being held in place by a thin cement of asphaltum. ${ }^{14 i}$

The remarkable resemblance between the shell-art of ancient California and that of the Pacific Islands is very significant.

$1 \pm 0$ G. A. Cooke, of. cut., ii., p. ro6; see also Niblack, "The Coast Indians of Southern Alaska and Northern Brilish Columbia." Rept. U.S. Nat. 1Ius., 1887-8 (I8go), pp. 225-386

14: F. II. I'utnam, "U.S. Geographical Survey west of the rooth Meridian : vol vil., Archeology:" Washington, IS79, pp. 232-3. 
CIIAPTER IV.

\section{The Use of Cowry-shells for the Purposes of}

\section{Currency, Amulets, and Charms.}

Of the many varieties of shells used for currency and as amulets, the most familiar and extensively employed are the cowries, especially the money-cowry (Cyprcea moncta) and the ring-cowry (Cyprea annulus) (Figs. $A \& B$, p. 156). The small size, shape, and substance of the latter renders them peculiarly adapted for use as money, and no other species of shell or form of shell-money has had so wide-spread and general use. They are distinguished by the fact that they can be and are used in a natural state, most other forms of shell-money being made from portions of larger species. Though known to science under two distinct names, the difference between the two forms is so slight that by some authorities they are considered as merely the extremes of one variable mollusc. ${ }^{1}$ Both forms are inhabitants of Indo-Yacific seas, and the specimens used as currency are derived mainly from the Persian Gulf, Maldive Islands, Ceylon, the Malabar Coast, the Sooloo Islands (between the Philippines and Borneo), and other East Indian Islands; also from various parts of the East African coast, ranging from Ras Hafun (near the

1 Melvill and Standen, Journ. of Conchology, ix., I899, p. 236 ; S. R. Roberts, "Monograph of the Family Cypreidie," in Tryon's "Manual of Conchology," vol. vii., ז885, p. ז79. 


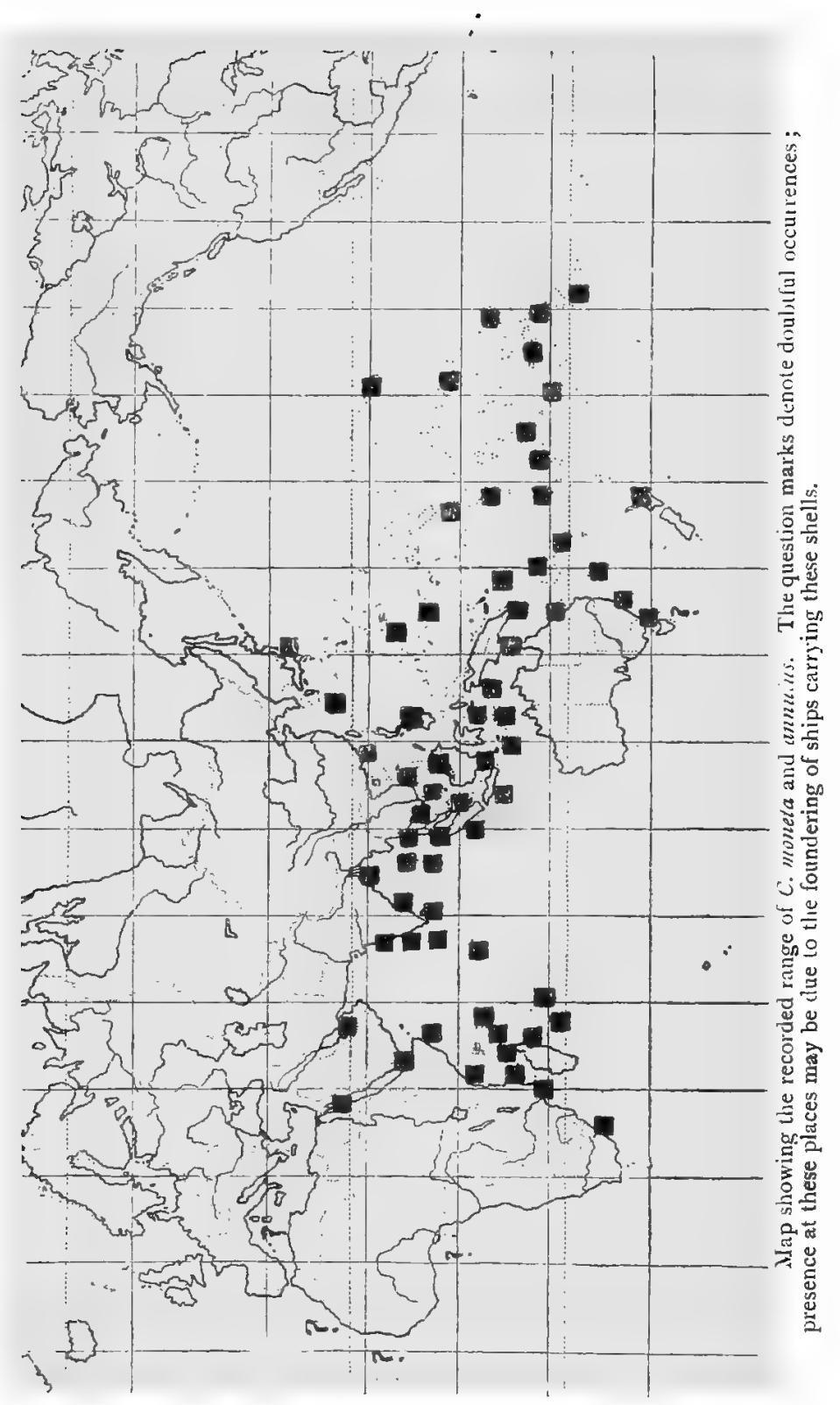




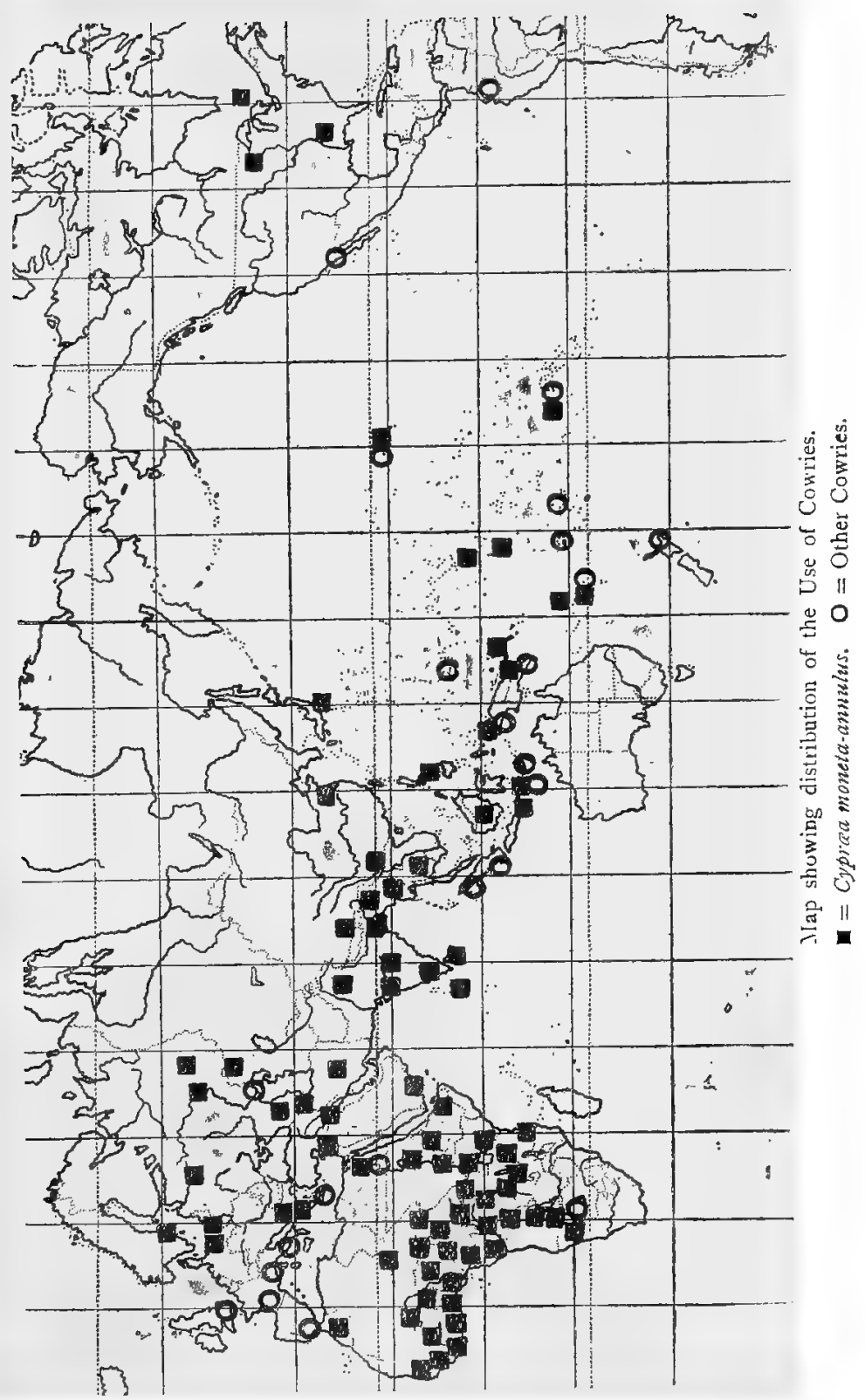


Gulf of Aden) to Mozambique. As currency these shells circulate not only through Southern Asia and certain of the Pacific Islands, but far into the African continent.

The term cowry, cowrie, or gowrie, is said by Dr. J. Cosmo Melvill ${ }^{2}$ to be derived from a Greek word meaning "a little pig," and according to Liddell and Scott this was probably the shell used by the Athenian dicasts in voting. "Following the example of the Greeks, the Romans termed these little shells porci or porculi, whilst the French nowadays term them pou de mer; and in the word porcelain we can also trace the same derivation" (Melvill, p. I86). Deniker, ${ }^{3}$ however, says the term cowry, cowrie, or cauri, appears to be a corruption of the Sanskrit word Kaparda, whence Kai'tri in the Mahrattan. Murray's dictionary ${ }^{4}$ gives the Hirıdī and Urdū equivalents as Kaurì (or $K a u d \bar{\imath}$ ). In Monier Williams' "Sanskrit-English Dictionary" ${ }^{5}$ the following interpretations are given: "Kaparda, as: a small shell or coivrie used as a coin and as a die in gambling, Cyprea moneta; braided and knotted hair, especially that of $S^{\prime}$ iva (knotted so as to resemble the corvrie shell). Kapardin, $\bar{\imath}, i n \bar{i}, i$ : shaggy ; wearing braided and knotted hair like a cowrie shell; epithet of Rudra, of Püshan, of the descendants of Vasishtha and of Durgā; (i) name of S'iva ; name of one of the eleven Rudras."

The Portuguese called the corvry Boudji or Boughi; the inhabitants of the Maldives, Boli; the Siamese, Bios (which means shell in general in Thai). By the Arabs it is known under the name ouoadda or vadaat (Deniker, op. cit.).

" J. C, Melvill, "A Survey of the genus Cyprea," Memois's and Proc. Manck. Lit. \& Phil. Soc., 4th Ser., vol. I. (1887-8), pp. 184-252. note.

3 Deniker, "Races et peuples de la Terre," Paris, Igoo, p. 324 foot-

" Murray, "New English Dictionary."

- Oxford, I872, p. 201 . 
The use of cowries as currency and as amulets or charms has been frequently discussed in ethnological memoirs. From this literature it is clear, though the fact has not always been realised or sufficiently emphasised by the authors, that cowries have been for ages regarded and even reverenced as charms in hunting and fishing, and as amulets against the evil eye. In fishing, especially in the Pacific Islands, they are attached to the nets to ensure luck, being misnamed "net-sinkers" by many writers on ethnology. They have been, and in many places are still, associated with marriage, with the object of securing communion with the spirit of fertility, supposed to be indwelling in the cowry. In like manner they are used in some places as offerings to rivers and springs in order to ensure that the rivers will run and springs flow.

In the following pages an attempt is made to show some of the many uses of cowries in different parts of the world. The remarkable manner in which some of the customs, in which cowries play an important part, crop up in widelyscattered localities is very significant, and goes far to prove a common centre of origin for these practices. It is altogether unreasonable to assume that exactly similar customs of so peculiar and wholly arbitrary a nature and identical beliefs concerning the cowry could have arisen independently among isolated groups of people.

The best and most comprehensive work on the subject of shell-money is that by Dr. O. Schneider, on "MuschelgeldStudien." " This work contains some I 80 pages dealing with the subject, of which about 72 pages are devoted to an excellent summary of the extensive literature relating to cowry-currency. Some use has been made of this work in the compilation of the present chapter, as will

"Dr. Oskar Schneider, "Muscheigeld-Studien" (Nach dem hinterlassenen Manuskript bearbeitet von Carl Ribbe). Herausgegeben vom Verein fiir Erdkunde zu Dresden. Dresden, 1905. 
be seen by the footnotes. Much further information, however, not noted by Schneider, is embodied here, more especially with regard to the use of cowries in Ancient Egypt, Eastern Asia, North America, and many other places.

Cowries appear to have been appreciated and used as amulets at a very early period in Egypt. Both Cyprea monete and Cyprea annulus-the forms so universally used for currency - have been discovered, along with other cowries, in Pre-dynastic burials, and both forms have been found repeatedly in later graves in Egypt and Nubia. According to Lortet and Gaillard, 'the following species of cowries have been found at Karnak: Cyprac vitellus, C. tigris, C. pantherina, C. camelopardalis (= melanostoma), C. arabica, and var. histrio, C.erythrcensis, C. caput-serpentis, $C$. moneta and $C$. annulus-all species which occur to-day in the Red Sea. The larger forms are perforated near one end as if for use as pendants. The examples of C. moneta and $C$. annulus are of peculiar interest from the fact that they have been rubbed down on the back or convex side-a custom which is still in vogue among the East African people to-day. Of further interest is the figure given by the same authors of a reproduction in diorite of a Cyprea moneta. This object, which is perforated for suspension, was found in the necropolis of Rizakat, near Gébélên, Upper Egypt. In a tomb (D I I4) at Abydos, of xviiith dynasty date, large numbers of Cyprea annulus were discovered, all of them having been rubbed down on the back, as at Karnak. ${ }^{8}$ The same

“ Lortet \& Gaillard, "La Faune Momifiée de l'ancienne Egypte: Mollusques," Arch. Alres. d"Hist. Nat. de Lyon, vol. 10, Lyon, 1909, pp. I08-II ; see also List of Species, pp. 310-3tr.

s T. E. Peet \& W. L. S. Loat, "The Cemeteries of Abydos," pt. III. 1912-1913. 35th Aem. Egypt. Explor. Fund, 1913, p. 30, pl. xii., figs. 6 \& 9. (The Series is now in the Manchester Museum). 
species, C. annulus is also recorded from Koptos" and -Nagadeh, probably of pre- or proto-dynastic date ${ }^{10}$ it is also associated with other objects, such as papyrus charm pendants, uzat eyes, etc., strung on knotted cords found at Kafr Ammar (xxiii-xxvth dynasty). ${ }^{11}$ Reisner in "The Archaeological Survey of Nubia (1907-8)" "'? gives a figure of a small cowry, rubbed down on the back, which is probably C. annulas; it is recorded as occurring in the C-group, New Empire, and later graves. Cyprea moneta occurs in the list of shells found in graves at El Amrah (Pre-dynastic). ${ }^{13}$ Other species of cowries discovered in Egyptian graves are as follows: Cyprea caurica? "PanGraves" at Balabish ; ${ }^{1+}$ C. arabica, Koptos; C. cameola, Ballas; C.erosa, Ballas; C. caurica, Ballas? ; C.pantherina, Nagadeh $;{ }^{15}$ C. arabica var reticulata Toukh, Upper Egypt. ${ }^{16}$

These discoveries of cowries in Ancient Egyptian graves are of great interest as being the earliest evidence of a special appreciation of these shells. That they were worn as amulets by the Egyptians cannot be doubted from the fact that so many are perforated for suspension.

The discovery of so many specimens of the smaller

"Flinders Petrie, "Six Temples at Thebes, 1896," London, 1897, chap. x., p. 30 .

10 Kdem. "Amulets," I914, p. 27, pl. xiv., f. 1o7b.

11 Ibid., p. 29, pl. xvii., f. I3 Ib, 131c. ; pl. xviii., f. I3 Iе, I3Іf.; pl. xix., f. I3Ig.

12 Vol. i., Archæol. Rept., Cairo, I9I0, pl. 66, f. 7 and pl. 7o, f. I. The C-group belongs to a period corresponding to the Middle Kingdom in Egypt.

13 D. Randall-Maciver \& A. C. Mace, "El Amrah and Abydos 1899" 1901," London, 1902, 1. 49.

14 G. A. Wainwright, "The Excavations at Balabish," Joutrn. of Egy'pt. Aschizol., ii., Oct., 1915, pl. xxv., f. 2 (named from photograph). "I'anGraves" are Nubian interments in Egypt and may belong to the period from 2000 B.C. onwards.

Ī These five recorded by Finders Petrie ( $f i d e$ Lortet \& Gaillard, op. cit., pp. 310-311).

is De Morgan (fide Lortet \& Gaillard, op. cit., p. 310 ). 
form, $C$. annulus, together in one grave (D I I4) at Abydos, would seem to suggest the possibility that cowries may have been adopted as a form of currency at that early date. According to Del Mar, ${ }^{17}$ Egypt "appears to have conducted its exchanges with cowries and scarabs, supplemented possibly at later dates by Lydian or Greek coins for foreign commerce, until the Persian conquest, when it was supplied with a national coinage, probably of very limited extent, by Cambyses and Darius." He further remarks: "The Indians who traded with Egypt used cowries for money; the Chinese, who also traded with Egy'pt at a very remote period. used 'tortoise' (probably cowrie) shells for money:" (Del Mar, p. 147.)

The money-cowry (Cyprea moneta) has been found at the famous cemetery of Koban, upon the northern slope of the Caucasus, almost midway between the Black and Caspian Seas, along with bronze and other antiquities. ${ }^{18}$ It has also been recorded from a sandy layer above the Tertiaries at Frankfurt-on-Main by Dr. W. Wenz, who reports the existence of extensive prehistoric settlements of different periods in the immediate neighbourhood. ${ }^{19}$ Another interesting record is that of Dr. H. Stolpe, who states that, among the foreign objects (Cufic money, etc.) found in the Island of Björkö, were many Upper Silurian fossils from Gothland, and Cretaceous fossils from Skane, also some shells of molluscs from the west coast of Sweden. But the most important shells were five examples of the money-cowry, Cyprea moneta." Speci-

17 Del Mar. "A History of Money," London, I885, p. I49.

18 "A Guide to the Antiquities of the Bronze Age" (British Museum), I904, p. I29; see also "Materiaux pour l'hist. prim. et nat. de l'homme," 2nd ser., xiii., June, i882, p. 260.

19 Nachr. Deutsch. Mal. Ges., 1911 , p. 104.

so Congrès internat. d'Anthropol. et d"Archéol. Prêhist., 1874, vol. ii., St ockholm, 1876, lpp. 6rg-29. 
mens of the ring-cowry (C. annulus) were found by $\mathrm{Dr}$. Layard in the ruins of Nimroud, ,1 and others of this form, rubbed down on the back, were met with in graves at Shusha, in Transcaucasia, associated with numerous carnelian beads, perforated animals' teeth, stone implements, and bronze and iron objects.."

Another find of special interest was made by Dr. Truhelka at the pile-dwelling of Donja Dolina, on the bank of the Save (Bosnia). Here urn-burials were met with in under-ground vaults which contained the incinerated remains of bodies and a wealth of grave-goods. From the valuable nature of the latter it would appear that the cremated persons were of great social distinction. The objects comprised fibule, beads of glass, amber, and enamel, and other articles characteristic of the late Hallstatt period. One of the chief objects of interest was "one urn, which contained a necklet composed of several hundreds of beads of amber, enamel, coloured glass, seven cowrie shells, two perforated teeth, and a large bead of clay without any ornamentation." ${ }^{23}$

Dr. Schneider (op.cit., p. I I 5), quotes many interesting discoveries of cowries in ancient graves, chiefly in the neighbourhood of Danzig-the great amber-producing region. According to this authority they were found at Marienhausen, in the government of Witebsk, where in I879, some 50 specimens occurred in a grave, doubtless belonging to Slavonic times; also in old pagan Lithuanian graves, at Rügenwalde in Pomerania, in the urn of a "giant's-grave" at Stolpe, on the well-known Pomerellen

21 S. P. Woodward, "Manual of the Mollusca," Reprint of 4th Ed., London, I890, p. 233.

22 Verhantl. der Berliner Gess. f. Anthrop., 1892, pp. 566-8; I894, p. 216.

s $R$. Munro, "Palreolithic Man and Terramara Settlements in Europe," Edinburgh, I9ा2, p. 473. 
face-urns as earrings ; further, several burnt and fractured specimens of Cyprac annulus were found in an urn from a stone-cist at Jakobsmiuhle near Mewe, and in a face-urn at Rheinfeld near Carthaus; Cyprea moneta in a grave near Praust, a Cyprea anmulus, prepared as an amulet, at Seehof near Kulmsee, $C$. moneta as earrings on face-urns at Stangenwalde and at Wilschen in Berent district, as well as in burnt condition in a face-urn at Czapeln; finally, several specimens of a Cyprea, too badly damaged by fire for exact specific determination, occurred in a face-urn at Bockau on the river Radaune, West Prussia.

In an essay by Dr. H. Conventz, of Danzig, on the introduction of cowries and related sea-shells as ornament in West Prussia in prehistoric times, ${ }^{2-1}$ further mention is made of discoveries, which he refers to the first century B.C., of Cypres anmulus. in face-urns at Rheinfeld, in Carthaus district, Suckschin, in Higher Danzig district, and Jakobsmiihle, in Marienwerder district, as well-as in an ordinary urn at Fronza, in Marienwerder district; and of Cyprea moneta in the ears of urns from Wilschen, Berent district, and Stangenwalde, Carthaus district, and in a faceurn from Praust, near Danzig ; further, of "Roman times," which corresponds to the Ist century A.D., Cyprea annulus attached to bronze-strip as a charm, found near Elbing and Seehof, in Briesen district; finally, of the "Arabicnorse epoch," a perforated C. moneta on the neck of a skeleton in the grave-field near the Grutschno Burgwälle, in the Schwetzer district.

Cowries of larger dimensions than Cyprea moneta and $C$. annulus have been met with in pre-historic pitdwellings and Saxon graves in our own country; in Franco-Merovingian graves in France; in the Gallo-

24 Correspondensblath d. deutsch. Gesell.f. A. E. u. U., xxxili, no. 2, 1902, (file Schneider, op. cit., 1.. I I5) 
Roman necropolis of Trion, at Lyons; and in Pompeii, as well as in other places.

The complete outer lip of Cypratigris, a species occurring in the Indian Ocean and Red Sea, has been recorded by $J$. R. le $B$. Tomlin, from a pre-historic pitdwelling at St. Mary Bourne, IIants. ${ }^{2 \pi}$ The same handsome species is recorded by $M$. Locard from the GalloRoman necropolis of Trion, and by Monterosato from Pompeii. ${ }^{26}$ Cyfreca pantherina, a Red Sea shell, has been found in Saxon women's graves, excavated on Kingston Down, and Sibertswold Down, in Kent, ${ }^{27}$ and in a grave near Wingham, Kent." It has also been recorded (under the name Cyprcea vinosa) by Dr. Ph. Dautzenburg from the Franco-Merovingian necropolis of Nesles-lez-Verlincthun (Canton de Samer). ${ }^{-14}$ Dr. Dautzenburg also refers in the same paper to a record by M. l'Abbé Henri Debout of the presence of this shell (erroneously referred to C. arabica) in. a sepulchre at Tardinghen; and from Dr. Tiberi's Memoir on the shells met with in the excavations at Pompeii, ${ }^{30}$ we learn that many examples of this species were found, and that the shell in question was an amulet which the women carried in order to prevent sterility.

In a footnote in 1)r. Schneider's paper (op. cit., p. I I6), reference is made to a description, by Dr. Koehl, of Merovingian graves at Weisoppenheim, near Worms, where cowries were found alongside the bodies of several women, either hanging from a girdle, or sewn to their dresses. Unfortunately, the specific name of the shell is

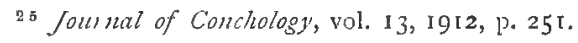

20 fute Tomlin, op. cit.

2 T Faussett's "Inventorium Sepulchrale," I856, pp. 68, 92 \& 133 . (See also J. W. Jackson, Jouru. of Conch., vol. 13, 19.2, p. 307, for discussion of species).

\footnotetext{
28 "Archreologia," vol. 30, p. 551 .

20 fourn. de Conchyliologie, vol. liv., I906, 1. 260, figs. I \& 2.

20 "Le Conchighie I'ompeiane," Napoli, I879.
} 
not given. In the same footnote mention is made of the discovery of a large Cyprea in an old German grave at Entibihl, and of an Indian Ocean Tritoninm, ${ }^{31}$ filled with worked flints at Brunswick.

A further discovery of a shell from the Indian Ocean, Orulum ounm, closely akin to the cowries, was made in a Gothlandic tomb. This specimen had a hole at one end in which was still fixed a little ring of bronze wire. ${ }^{: 2}$

In Crete, black cowries, probably dark forms of Cyprea pantherina, were found in excavating the rooms of Mycenaan houses. ${ }^{33}$

In a paper on "Cave Explorations at Gibraltar in September, I9Io," " Dr. IV. L. H. Duckworth records the discovery of a Mediterranean cowry, Cyprecr pyrum, in excavating Cave $\mathrm{S}$. The specimen is remarkable on account of an artificial perforation at one end, as if for suspension as an amulet. On the evidence of the human remains and the pottery found, the cave is assigned to the Neolithic period. In the same cave were found specimens of Purpura hamastona with the apical parts fractured in a curious manner, suggesting that the mollusc had been used for the preparation of its distinctive product, the Tyrian Purple.".

A perforated specimen of Cypreen pyrmm is recorded by Lartet and Christy ${ }^{36}$ from La Madelaine cave, Périgord, along with other perforated shells and teeth of animals, but in this case the cowry is said to be a fossil, probably

31 ? 7 riton, the shell employed as a trumpet in many places.

Q2 IIans Ilildebrund, "The Inctustrial Arts of Scandinavia," (South Kensington Museum Art Ilandbook), 1882, p. 40.

23 Ann. Brit. Sch. Athens, ix. (1902-3), pp. 291 and 335.

$3 \pm$ Journ. Roy. Anthrop. Insl., xli., I911, p. 362, pl. xl., fig. 4, 5.

so See chapter $\mathrm{i}$.

sc "Reliquixe Aquitanice," London, 1875 , p. 48 (Description of the Plates), pl. v., fig. I5. 
from the Faluns of Touraine. Mention is also made of a collection of objects from the Cave of Bruniquel, comprising carnivore teeth and perforated marine shells, including a Cyprea an inch in length, not improbably derived from the Miocene beds of the Garonne. ${ }^{37}$

Since Christy's diggings in Laugerie-Basse, ${ }^{38}$ this cave has yielded many other interesting objects, including two species of Mediterranean cowries, perforated for use as pendants. Particulars of the discovery of the cowries are given in a paper by Massenat and others" dealing with the finding of a human skeleton (the so-called homme ecrassé) in this cave. The latter seems to have been a ceremonial interment in the contracted posture. The situation of the objects which accompanied the skeleton was studied with scrupulous attention and a score of shells were found. These were determined by Mortillet as belonging to two different species of Mediterranean cowries, Cypraa pyrum, Gmelin (or rufa Lam.), and Cyprea lurida $L$. The most interesting fact concerning them is that they were arranged in pairs upon the body; two pairs on the forehead, one near each humerus, four in the region of the knees and thighs, two upon each foot. The discoverer dismisses the idea of a necklace or bracelets and suggests they were intended to adorn a garment. Each cowry was pierced with a notch.

Cowries have also been found in the celebrated Mentone Caves alongside human skeletons, which can with

"i Ibid., p. I79 (Text).

is Ibid., p. 288 (Text).

: 5 E. Massénat, Ph. Lalande \& Cartailhac, "Découverte d'un squelette humain de l'âge du renne à Laugerie-Basse (Dordogne)." Countes liendus de $l$ Acad. des Sciences, vol. 74, I872, pp. I060-3; also Paul Girod and I. Massenat, "Les Stations de l'Age du Renne dans les vallées de la Vézère et de la Corrèze-Laugerie-Basse," Paris, 1900, pp. 24-5. Sollas ("Ancient Hunters," 2nd Ed., I915, p. 509, fig. 288) gives a figure (after Cartailhac) of this interesting burial, with the associated shelis. 
considerable confidence be correlated with those found in the valley of La Vézère, at Laugerie-Basse, Cro-Magnon, Gourdan, and Chancelade. Villeneuve ${ }^{40}$ records, amongst other shells, one Cypreca, from an occupation level (Foyer D), $3 \mathrm{~m}$. I 5. from the surface, in La Grotte des Enfants. The specific name, unfortunately, is not given. On the same level a remarkable find was made of Cassis mfa, an Indian Ocean shell."

At Barma Grande, another of the Mentone Caves, various kinds of ornaments of teeth and bone, and perforated shells of Nassa neritea, were found, in I892, near the head of one of the skeletons discovered there; but the most interesting and remarkable find was that "on each thigh bone above the knee was a perforated cowry." 42 The body is said to be that of an old man. It is of interest to note that all the skulls found here are stated to be of

40 "Les Grottes de Grimalcli (Broussé-Roussé)," Tome i., Fasc. I. "Iistorique et Description." By M. L. de Villeneuve (p. 65). (Imprimerie de Monaco, 1906).

41 Tbida, Tome i. Fasc. 2. "Géologie et Paléontologie." Ry Prof. Narcellin Butle (p. I23); In a footnote to this payse, G. Dollfus remarks : "Cassis rufa L., an Indian Ocean shell, is represented in the collection at Monaco by two fragments; one was found in the lower halsitation level $D$; the other is probably of the same origin. The presence of this shell is extraordinary as it lias no analogue in the If ititerranean, neither recent nor fossil ; there exists no species in the North Atlantic or off Senegal with which it coukl be confounded. The fragnents have the traces of the reddish colour preserved and are not fossil; one of them presents a notch which has cletermined a hole that seems to have been made intentionally. The species has not yet been found in the Gulf of Suez nor in the raised-beaches of the Isthmus. M. Jousscaume has found it in the Gulf of Tadjoura at Aden, but it has not yet been encountered in the Red Sea nor in the raisedbeaches of that region. The common habitat of Cassis rufa is Socotra, besides the Seychelles, Madagascar, Mauritius, New Caledonia and perhaps Tahiti. The fragnents tiscovered at Mentone have therefore been brought from a great distance, at a very ancient epoch, by prehistoric man."

42 Munro, "Paleolithic Man and Terramara Settlements in Europe." Edinburgh, 19I2, p. 163. [At p. 235, perforated teeth and shells, Nassa, Cyprica, Peitunculus, etc., are mentioned as being found at the Rock-shelter of Cap-Blanc (Laussel), Dordogne]. 
the Cro-Magnon type, and that all the bodies had been definitely interred. The discovery of cowries and the relation of these to the body, forms an interesting parallel to the Laugerie-Basse burial referred to above.

The association of perforated cowry shells with men belonging to the Cro-Magnon group is not without interest when it is remembered that these people were members of our own species-Homo sapiens, and quite distinct from the earlier Neanderthal people. That they were men capable of formulating ideas and enclowed with an artistic sense is unquestionable. The skeletons of this race all seem to have been ceremonially interred, which certain writers regard as implying that they were not without some idea of religion. The fact that they used perforated shells, teeth, and pendants, as amulets, also supports this conclusion. But, of course, the validity of the inference depends upon what is meant by the term "religion."

How this race came into the south of Europe and where it came from is not easy to determine; but the slender evidence at present available disposes us to look to North Africa as its immediate source. It seems possible that these people may have been an early sporadic invasion from, or at least have been in direct or indirect contact with, the region where civilisation first developedthe valley of the Nile and Western Asia.

The skull of the Cro-Magnon man has so many points of similarity to that of Neolithic man in England, that, in defiance of the archrological evidence, the former race was judged at one time to belong to the Neolithic period. Leading authorities now agree in relegating it to an earlier time, which includes the Magdalenian period. ${ }^{4 ;}$

43 The culture of the Cro-Magnon race is certainly quite distinct from that of the Lower Palaolithic people-Neanderthal man, and on thin account Dr. Elliot Smith has suggested the term "Neoanthrophic phase of culture," in order to give specific emphasis to the profound break in human history 
As Dr. G. Elliot Smith has pointed out, many similarities exist between Magdalenian and the later Azilian implements, and also of both of these to those of P're-dynastic Egypt. This suggests the possibility of the Magdalenian period in the west being approximately contemporaneous with the pre-dynastic period in Egypt, and that the Neolithic period in Western Europe clid not begin long before the third millennium B.C.

In connection with the above it is of interest to note that the cowry is frequently associated with pre-dynastic burials in Egypt.

The numerous discoveries of cowries detailed above serve to show the migrations or intercourse of early peoples. They are not to be regarded as evidence of the shells, even the smaller kind, having been employed as currency in the localities where they were found, nor indeed are they to be looked upon as having been worn from purely asthetic motives. Their presence may be explained by the part cowries played in early times as symbolic of the generative forces of nature. The shell itself was not worshipped, but rather regarded as an attribute of some goddess. It was due probably to this fact that the cowry was known to the ancients under the appellation of "Concha Venerea," - the shell of Venus." As pointed out by Dr. J. C. Melvill, ${ }^{46}$ the generic name of between the Lower and Upper Palæolithic. The Lower Palrolithic, he suggests, may be known as the Palzeanthropic, the Upper as the commencement of the Neoanthropic, Age. (See "The American Museum Journal," vul. xil., May, I9r6, p. 325.)

44 Abstract of paper on "The Commencement of the Neolithic Phase of Culture," read before the Manchester Literary and Philosophical Society, April 4th, 1916.

45 As well as the goddess of love, the word Venus signifies the highest throw of the dice. (IIorace, 'Carmina,' 2, 7, 25.) It is not surprising, thetefore, that we find the cowry-the shell of Venus, used in so many games of chance.

40 "Survey of Genus Cyprea," op. cit., p. I84. 
this group of shells, "Cypræa, or more classically Cypria, is derived from one of the many attributes of Aphrodité, owing, doubtless, to her worship not only having been inaugurated, but for long years principally centralized, in Cyprus, then a luxuriant and smiling island, teeming with industrial wealth. Horace ${ }^{\star \bar{\gamma}}$ addresses her as 'Diva potens Cypri,' and Tibullus, ${ }^{\text {} 8}$ when apostrophizing the goddes,', thus: 'Et faveas conchâ, Cypria, vecta tuâ.'"

As previously remarked, cowries were worn as amulets by the women of Pompeii in order to prevent sterility. The presence of these shells in women's-graves in France and the South of England seems to point to the prevalence of the same ideas in the Middle Ages.

In the I 8 th century the custom of wearing a large cowry as an amulet or charm was prevalent among Kendure Tartar women and girls. ${ }^{49}$ And in the neighbourhood of Naples, cowries, it is stated, are still worn by the poorer class. ${ }^{50}$ Money-cowries are used by the Bedouin women of the Hadramaut, South Arabia, to adorn their girdles; $;$ ' also by the women of the races of the Volga region, as breast and forehead ornaments by the Tshuwash and Mordvins, and as necklaces by the Tsheremis. They are also to be seen on the necks of the Kirghis women, and on the curious head-dresses of the Bashkir women ; $^{5:}$ and

47 Horace, Ol., I, 3, 1.

4s Tibullus, III., $3,4$. p. 448.

4. G. A. Cooke, "System of Unirersal Geography," vol. i. (I 801 ),

so Faussett, "Inventorium Sepulchrale," 1856, p. 68.

${ }^{\circ}$ Schneider, op. cit., p. 117 ; Strabo, bk. xvi., ch. iv, par. I7 (Bohn's Ed., vol. iii., p. 202), speaking of the Troglndytre of the Arabian Culf says: "The women carefully paint themselves with antimony. They wear about their necks shells, as a protection against fascination by witchcraft."

62 Schneider, op. cit., p. I17; Ratzel, "History of Mankind," iii., p. 327, gives a figure of one of these Bashkir head-dresses ornamented with small cowries. 
in England they are occasionally noticed worn in long strings by travelling gypsies.

According to Professor Ridgeway, cowries are still used, combined with a Christian medal, in Corfu as a child's amulet; and also in Montenegro.

In the following pages frequent references will be found to the use of cowry-shells as amulets of magical import in Africa, Asia, l'acific Islands, anc elsewhere.

The custom of decorating the trappings of horses with cowries, doubtless with the object of averting the evil eye, is found in Persia as vell as in India (where elephants carry such ornament), in Hungary and in Norway. And according to Ridgeway (op. cit., p. $24 \delta$ ), Mr. F. W. Hasluck, when travelling in the Morea in 1907, saw a boar's tusk charm on a horse in Triphylia, with a pendant of a cross formed of four cowries sewn on leather.

Lane, in his "Modern Egyptians," if informs us that cowries are still used by the people of Egypt, and are regarded as a protection against the evil eye. With this object they are often attached to the trappings of camels, horses, and other animals, as well as to the caps of children. Pickering ${ }^{55}$ remarlis that on ascending the Nile to Kenneh, the modern capital of the Thebaid, about 30 miles below the site of ancient Thebes, cowries were seen used as money by market women of the Ethiopian [? Soudanese] race. Culin, in his "Chess and l'laying Cards," reports that in the streets of "Cairo" at the Columbian Exposition was a family of Bishareen from the Eastern desert, near Assouan,

¿ 3 W. Ridgeway, "The Origin of the Turkish Crescent," Jorm"n. Roy. Anthrop. Tust., G. B. and I., vol. 38 (1908), P. 248, pl. 2I, fig. 23.

54 E. W. Lane, "Modern Egyptians," vol. i., I 849, p. 343 -

t5 Pickering, "Races of Man" (Bohn's Iid.), I 863, as quoted by Stearns, "Ethno-conchology," Rept. U.S. Nat. .1/ts., 1887, (1889), p. 303.

so Stewart Culin, "Chess and I'laying Cards," Rept. U.S. Nat. Mlus., I $896,(1899)$, P. 81 5 footnote. 
whose headman practised soothsaying with cowries. He threw several cowry-shells, and made his prediction from the manner in which they fell.

At Sennaar, in the Soudan, cowry-ornament still obtains to-day among the Hassanieh Arabs. Caillarud, in the 2oth year of last century, saw cowries ornamenting the fringed girdle of the young girls in Sennaar. According to Carl Ritter, they are still found as trimmings for women's girdles in Abyssinia ; ${ }^{5 \bar{T}}$ and Haldeman ${ }^{59}$ describes a curious Abyssinian necklace composed of European beads, cowry-shells, bits of brass, copper coins, etc.

According to Schneider (op.cit., p. I 73), a large leather object from Somaliland, richly ornamented with cowries, is in the Dresden Museum, ${ }^{5}$ and a similar object, ornamented in the same way, was brought from Somaliland by Riebeck in 1883 . That the cowry was in use here in early times is proved by the discovery of Cyprea anmulus, along with glass, enamel, stone and other objects, in the ruins of Bender Abbas, near Berbera. The age of these ruins is still problernatic; they may belong to "Persian times." ${ }^{60}$ Presumably this refers to the period of the Persian conquest of Egypt in the sixth century B.C.

In the Upper Nile region cowries, rubbed down on their backs, are used by many negro peoples. The Lango, Latuka, Lur, Shuli and Nuer have very many cowryornaments, more especially on their head-coverings. According to Ratzel ( $o p$. citt., iii., p. 30), the head-coverings of the Shuli and Lango " consist of strong bass-matting, close set with concentric rows of cowries, with a woven blunt appendage, shaped either like a flat conical cup or like a

67 Schneider, op. cit., p. 173 .

"S S. S. Haldeman, "United States Geographical Surveys West of the Iooth Meridian," vol. vii., Archicology, 1879, p. 263.

- 9 See also Ratzel, op. cit., ii., fig. 14 of plate facing p. 533 .

o Schneider, op. cat., p. 118 . 
helmet enclosing the head and hanging down the back of the neck" (see also Ratzel, op. cit., i., p. IOI). Among the Latukas and their kinsfolk heavy wicker helmets, with crests recalling Greek forms, are used; these are ornamented with a ring of cowries all round (Ratzel, iii., p. 30, and p. 4I, fig. 7). Among the Djibba tribe of the Sobat country, one of the Nile tributaries, cowries appear to be associated with head-hunting, as among the Nagas of Assam (infra, p. I72). Like these latter people, the Djibba warriors wear the hair taken from the decapitated heads of slain enemies, in addition to ivearing goat-skin dresses, ivory armlets and belts of couries. ${ }^{61} \quad B y$ the Jurs, beads and cozery-shells are considered as essential at betrothals. ${ }^{62}$

In East Africa rubbed-down cowries ${ }^{63}$ are used largely by the Akikuyu, Kavirondo, Akamba and Masai peoples. Kavirondo men are noted for their peculiar and elaborate head-dresses made of these shells. Among the Akamba, Masai and other tribes, cowries appear to be associated with unmarried girls (as among the Chettis of Southern India, infra p. 170). The young unmarried girls of the Akamba tribe wear belts and aprons adorned with beads and cowries; but these ornaments are discarded after the birth of the first child. The Masai women also wear a peculiar head-band covered with cowries during the period of "engagement." The Lumbwa girls' aprons, too, are similarly adorned, doubtless with the same significance." Ridgeway, in his paper on "The Origin of

"1 Brown, "Races of Mankind," iii., p. 16.

B S Schneider, op. cit., p. 173 .

${ }^{3}$ On the East side of Africa, the ring-cowry (C. ammuius) appears to be the form universally used.

64 "Women of all Nations," pp. 266 and 268.

- 5 Specimens in the Manchester Museum; see also Journ. Anthrop. Inst, vol. 33 (1903), pl. xxix,, for illustration of a Lumbwa girl wearing one of these cowry-ornamented aprons. 
the Turkish Crescent" (op. cit., p. 253, pl. 25), figures and describes two curious head-dresses worn by the Ja-luo of Kavirondo, one consisting of ram's horns and cowries, the other of reed-buck's horns and cowries. These remind us, Ridgeway remarks, of the combination of boars' tusks and cowries in Greece (supra p. I40). Captain R. F. Burton gives us an interesting account of the cowry-trade of the regions north of the 'Land of the Moon,' in his description of "The Lake Regions of Central Equatorial Africa." The cowries, he reports, are collected from various places between Ras Hafun and Mozambique, the trade being in the hands of Moslem hucksters. They are purchased on the mainland by a curious specimen of the 'roundtrade'; money is not taken, so the article is sold measure for measure of holcus grain. From Zanzibar the use of cowries spreads in two directions; one to the regions north of the 'Land of the Moon' where they form the currency, though they are also occasionally in demand as an ornament in Unyamwesi ${ }^{67}$ the other to the West African coast. That the collecting of cowries on the East African coast dates from ancient times is evident from the list of articles of export at Rhapta in the first century A.D. Among the articles mentioned in the "Periplus "68 as exported from this place-the Quiloa or Kilwa of modern times-is an item, $\mathrm{N} a ́ u \pi \lambda \cos$ ódíyos (lit. little seashell), a term which has given rise to some discussion. Vincent" says: "It seems to be an inferior tortoise-shell from the context" (which he translates, "tortoise-shell of superior kind, but not equal to the Indian; and a small

os Tourn. Roy. Geog. Soc. Lond., vol. 29, I859, p. 448 .

${ }_{67}$ See Ratzel, op." cit., ii., plate facing p. 533, fig. 1 , for cowry ornamented head-dress of Wanyamwesi.

\& 8 Vincent, "The Commerce and Navigation of the Ancients in the Indian Ocean," London, 1807, vol. ii., p. 172.

co jbid., p. 748 . 
quantity of that species called nauplius"). "It may, however, be a different commodity." As cowries are an article of commerce on this coast to-day, the suggestion naturally presents itself of interpreting the term as a reference to shells (? cowries) intended for ornament.

In Uganda, cowries have been a recognised form of currency from an early date. According to the Rev. John Roscoe, ${ }^{\text {io }}$ the standard of currency among the Baganda was set by the value of the cow. During the reign of Suna, he tells us, a cow was sold for 2,500 cowry-shells; a goat for 500 ; a fowl for 25 ; a large cock for 50 ; and an ivory tusk weighing sixty-two pounds was valued at I,000 cowry-shells. ${ }^{71}$ Cooking-pots were priced according to size; a large pot was sold for 200 cowries, small ones for 20 or 30 cowries. A milk-pot cost 60 or even 100 cowries; a tobacco pipe from 5 to Io shells; and a waterpot from 40 to 50 shells." "Before the introduction of cowry-shells," Roscoe informs us, "a blue bead (nsinda) was used; this was very rough and badly made, but it was considered to be of great value; one bead was of equal value with one hundred cowry-shells. Still earlier, before the introduction of the bead, a small ivory disc was used, known as sanga; one of these discs was valued at one hundred cowry-shells. When the cowry-shell was first introduced, which was probably in the reign of King Semakokiro, two cowry-shells would purchase a woman." 73 By these same people cowry-shells have also been used from the first in religious and other ceremonies. One of the many interesting uses, mentioned by Roscoe, is their employment in the decoration of an amulet called Luaalo, which partakes of the nature of a fetish,

70 Roscoe, "The Baganda," London, I9I I.

71 Ihid., p. 456.

72 Ibid., p. 455 .

7 is Tbid., p. 457. 
and is designed to insure fecundity. This consists of a piece of wood sewn into a small cat-skin bag ornamented with cowry-shells, which is worn round the waist, so that the amulet rests in front of the wearer ${ }^{74}$ Divination is also practised by means of pieces of leather decorated with cowry-shells. They are also offered to propitiate the spirits of trees; and sent by the king as presents to each of the important deities. Another most important use is to decorate the jawbones of deceased kings. Some five months after the death and burial of a king the tomb is entered and the head severed from the body and brought away. The jawbone is then removed and placed in an ant hill until all the flesh is eaten away, the skull meanwhile being given special burial in a place near the tomb. The jawbone, after being cleansed and washed in beer and milk, is wrapped in fine barkcloth which has been rubbed with butter, and is decorated with beads and cowry-shells collected during the king's lifetime from people succeeding to chieftainships. A temple is then built to receive the decorated jawbone and umbilical cord of the late king, and also the umbilical cord of the ex-queen. ${ }^{\text {in }}$ At the end of the royal mourning cowryshells are thrown on the fire as if they were fuel; this is also done at ceremonies to prolong the king's life. ${ }^{76}$

In the marriage ceremonies of the Baganda these shells form an important part of the dowry, the bridegroom having to provide as many as two thousand five hundred." On the birth of twins it is the custom for the grandmother to make each twin a present of cowry-shells, and everyone coming to see them throws cowry-shells into a basket

\footnotetext{
74 Ibid, p. 33r.

75 Tbid., pp. 109-10.

70 lbid., p. 108.

77 Ibid., pp. 88-9.
} 
placed to receive these offerings. ${ }^{78}$ On the death of a twin the body is embalmed and the ghost is caught by the medicine man and made up into a "twin" (mulongo). To do this, the man goes by night into a space in front of the house, spreads a barkcloth on the ground, kills a white fowl, cuts out its tongue, and places it on the barkcloth ; he then watches for the first insect that alights on the barkcloth, catches it, and wraps it up with the fowl's tongue, saying that the ghost has come back again. The insect and fowl's tongue are then made up into a "twin" decorated with cowry-shells and beads, put into a wooden pot and preserved. ${ }^{79}$

In addition to the above uses, cowries are employed by the Baganda to decorate the royal drum. Drum-sticks made from human arm-bones are also ornamented with them, as well as the stool of the war-god Kibuka. ${ }^{80}$

According to Stuhlmann, cowries were used in Karagwe, on the west side of Victoria Nyanza, to ornament the leather-cuff which serves as a protection of the left wrist at archery, and in Unyora, north-west of the above lake, the most important personage wears, as token of his rank, a strip of cow-hide adorned with cowries and coloured glass beads. The Wassongona and Wahuma have cowries as neck-ornaments, and the young girls of the latter wear a hip-cord of cowry-shells and beads, which are sewn on leather strips. ${ }^{\mathrm{gl}}$

According to Schweinfurth the Madi and Niam Niam wear cowry-ornaments, but they do not appear to be of great importance among the latter people. Cowries were much sought after in former times by the Bongo, but they have long since fallen out of the category of objects

$7 \mathrm{~s}$ Ibid., p. 7I.

73 Ibid., p. I24.

30 Ibid., Pp. 26, 214 and 306, fig. 49.

$\$ 1$ Schneider, op. cit., p. 172. 
of value. ${ }^{8:}$ Schweinfurth also depicts a fashion in hair among the Monbuttus, by which the head is surrounded with a regular saint's halo. The hair, in plaits, is spread out round the whole head and fastened to a hoop adorned with cowry-shells. ${ }^{83}$

The Wavira of the upper Ituri wear in their ears a wooden plug with cowries at both ends; this object is in the Lunda Empire an amulet hung by a string from the . neck. $^{84}$ Cowries were also seen by Junker used as ornaments by the Bagarambo on the Welle River. And Thonner reports cowries in common use by the Mogwandi north of the upper Dua and by the neighbouring races; by the Mobali in the hair, and by a Banza man from Bogola as a neck-chain. On the middle and upper Ubangi and on the Welle to its source cowries pass current as money; they are also in use as such by the Basoko inhabiting the region of the Congo between Stanley Falls and the Aruwimi confluence. In I886 Lenz saw them used for ornament by the Nkaia at Riba Riba above the Stanley Falls, as well as in other places. According to Johnston cowries were made use of as small-change everywhere on the Upper Congo. Large numbers of them were placed in the graves with the dead. In Nyangwe they were in use along with other objects of barter in Livin'sstone's (I87I), Cameron's (I874), Stanley's (I 876) and Pogge's time, and often served as presents for the chiefs and for purchasing necessary articles of food in the districts through which these and other travellers passed. In Uhombo, between the Congo and Lake Tanganyika, they were the current money in Stanley's time. At Mpala,

\&2 Ibid., p. I73; and Schweinfurth, "The Heart of Africa," London, 1873, vol. i., p. 299 ; ii., p. 9. figure).

83 Ratzel, op. cit., iii., p. 69 ; Schweinfurth, op. cit., ii., p. 7 (Text-

84 Ratzel, op. cit., iii., p. 69. 
on the western shore of Lake Tanganyika, they were seen by Richard as head-ornaments or sewn on straps; he also observed them in use by the Nollo Nollo, living north thereof, to ornament the forehead, neck and wrist; in the latter case, two shells were worn attached to the middle of a thin strap, probably an amulet of some kind. Among the Warua of the Upper Congo similar ornaments were noticed. ${ }^{85}$

On the middle Congo cowries are a recognised currency about Lukolela, Ngowe, Matumba Lake, etc., being used by the Balolo people. On the Mongalla, Thonner, in I 896 , found cowries the necessary legal tender for continuing his journey up the river and for the purchase of food-stuffs. Wissmann, Wolf, and other travellers found them highly estimated in the Kassai-Sankuru basin. According to Wolf, in I 885 , these shells together with a black and white striped glass bead were used as bartermaterial by the Baluba people of this region. ${ }^{86}$

In the Lunda Empire, the wooden plug set with cowries at both ends, which the Wavira wear in their ears, is hung by a string from the neck as an amulet. ${ }^{8 i}$

According to Magyar, cloth in Kimbundaland, about I 850 , was reckoned at from 25 to 50 cowries, or busioshells, per ell or yard, according to the distance from the coast; and this same observer tells us that the women of the Mondumbe, inwards from Beriguela, ornament their hair with small white cowries (C. moneta? Oliva?) ${ }^{88}$

In describing the Ovambo, Ratzel (op. cit., ii., p. 54I) informs us that they barter ivory for beads, iron, copper, shells, and cowries, with the Portuguese-speaking black traders on the further side of the Cunene River. Such

\footnotetext{
:5 Schneider, op. cit., various pages.

$\because$ Itide.

st Ratzel, op. cit., iii., p. 69.

$\therefore$ Schneider, op. cil., pp. 159 and 172.
} 
articles as they obtain in this way, and do not themselves need, they trade away to the south and east. On another page ( $p .553$ ) of the same volume, he gives an illustration (after Serpa Pinto) of Kimbande-Ganguellas with cowryornament. It is of interest to note that the shells (C.moneta or annulus), are employed by the women and girls as a decoration in connection with their curious method of hair-dressing; the man shown in the illustration has no such ornament. According to the observation of Waitz, cowries were usual as ornament among Hottentots and Kaffirs." Unfortunately no indication is given as to whether these were the small white money cowries, or some other. From Ratzel's figure (ii., p. 268) of a Bushman amulet, consisting of large cowries attached to a sort of belt, it would appear that cowries other than those so universally employed for currency are used also in the south. It is impossible to define the species from the illustration, but it appears to be a large spotted one, probably $C$. tigris, whose nearest habitat is off the East African coast, in the neighbourhood of Zanzibar.

Returning north, to the French Congo, we find that, according to Foret ${ }^{90}$ the races on the Tem and on the Ivindo use cowries as ornaments. Lenz, in 1876 , found them so employed in the hinterland of Gaboon. Kund also reports cowry-ornaments for the neck among the Bateke, not far from Leopoldville. Dennett ${ }^{21}$ figures a Bavili "guardian fetish," called Mpembe, consisting of a wooden image in the shape of a man, the eyes of which are cowry-shells with the apertures outwards. Ratzel

*s Schneider, op. cit., p. 172 : According to Peringuey (Ann. S. Afr. Alus., viii, I9I I, p. 104), Sparrman mentions and figures Ilottentot ornaments of marine shells (Nerita albicilla ?) and a leather head-dress adorned with three spaced rows of "cowries."

" Le Mouvement Géographique, 1902, No. 9 (fide Schneider).

91 R. E. Dennett, "At the Back of the Black Man's Mind," London, Igo6, p. 9r, pl. 5 . 
(op. cit., iii., p. 83 , fig. i.), also gives an illustration of a Beneki fetish with cowry-eyes, which has a strong resemblance to the Bavili example.

In the Cameroon district the use of cowries as currency seems to have ceased, but the shells are applied as ornament. Zintgraff writes that in Adamawa and the frontierland such was the case. The Bali warriors were allowed to carry a bandolier upon which the cowries were sewn in two rows, the channelled opening of the shell being to the outside. They were also seen arranged in cross-form on a small, flat, cloth packet, which was worn on a string from the neck, resembling the amulet which the Mahommedan wears. Another interesting use noted by Zintgraff is that by the chief of the Bafut, living on the Adamawa frontier, who had utilized cowries as a sort of mosaic on the floor of his spacious palm-wine hall. ${ }^{92}$ The shells are also worked into the coiffure of the women in the Cameroons, as many as two hundred being required.9?

We now reach the chief zone of circulation of the cowry-the western Sudan and Guinea coast. For many centuries the shells have passed as a means of currency throughout the greater part of this region, and in many places they have also played an important part in religious and other ceremonies.

Our earliest knowledge of their employment in this region as currency dates from the 14th century, when the Arab traveller Ibn Batūta saw them in use for transacting business at Kawkaw (Gao or Gagho) on the Niger. ${ }^{94}$ Cadamosto, who visited Cape Verde in 1455, also noted the white shells, "porcellete or cowries," used in exchange

92 Schneider, op. cil., p. $17 \mathrm{I}$.

93 Joyce and others, "Women of all Nations," p. 35 I.

" "The Travels of Ibn Batūla," Iranslated by the Rer. Samuel Lee, London, I829, p. 241 . 
between the Arabs and the natives of the interior..$^{95}$ Leo Africanus, ${ }^{96}$ who wrote at the beginning of the 16 th century, mentions in his description of Timbuctoo that "the natives of this place use small mussel-shells or snail-shells, which were brought from Persia, of which 400 equal one ducat, and six and two-thirds go to a Roman ounce." In Benin, at the end of the I $5^{\text {th }}$ century, according to Pereira, cowries, under the name Iguru, were in currency. In the description of Commodore Stewart's embassy journey to Mekines (Mequinez) in I72I, it is stated : " "The goods, which they (the Moroccans) convey to Guinea, are salt, cowries, etc.-Cowries are small shells, which are brought from the East Indies, and they are current instead of ready money, and as such have the highest value."

From Timbuctoo and the Upper $\mathrm{Niger}^{98}$ the territory of the cowry-currency extends to Lake Chad, with wide spaces here and there in which the cowries do not, or only in a minor degree, pass as currency. Barth mentions three such places within the great bend of the Niger,Aribinda, where the shells had no value, and Isaye (Ise) and Bambara, where they were employed only in the sale of milk. The places noted by Barth as having the cowrycurrency were Kabara, near Timbuctoo, Saraiyamo, Kubo, Dore, Bundore, Sinder and Say on the Niger; Gando, Sokoto, Wurno, Bamurna, Badarana, Kammane, Bunka, Katsena, Kano, Lamisso, Kukameirua and Gummel, all in the northern part of Sokoto State; Tasawa, immediately north of the Haussa region; as well as Zinder, Wushek,

${ }^{5}$ Deniker, "Les Races et les Peuples de la Terre," Paris, 1900, p. 324 ; Schneider, op. cit., p. II 9.

o Leo Africanus, "Description de l'Afrique," Lyon, 1556, p. 225 (fide Schneider, op. cit., p. I19).

97 Thos. Winterbottom, "Nachrichten von der Sierra-I_eone-Küiste" p. 22 I (fide sichneider, op. cit., p. I 19).

us Segu, Jenné, Kaarla, etc. 
Muniyo, and Kuka in Bornu. In the Haussa States, Clapperton, in 1826, found the shells in general use as money, and his companion, Richard Lander, mentions cowry-currency in Kano, Womba, Catup, Kazigee and Ragada in S.W. Haussa district. Rohlfs, on his 1867 journey from Kuka through Gujeba and the southern Sokoto beyond Yakoba to the Benue, and down this river to its junction with the Niger, and then up to the Rabba, finally passing through Ilorin and Yoruba to the coast at Lagos, moved throughout in the region of the cowrycurrency. In the district of the Marghi, cowries did not circulate as money in Barth's time, yet he managed to obtain two fowls with them, owing to the fact that the shells were desired as ornament by the "young ladies."

In the I $7^{\text {th }}$ and I8th centuries cowries were used very largely by the slave-traders of the Guinea coast from Senegal southwards; but in later times, English gold and the American dollar, together with other articles of exchange, displaced the shells to a very great extent. Where not actually in use as money, they still continue to be employed for ornamental and other purposes.

The territory of cowry-ornament in Western Africa is of much wider extent than that of the cowry-currency. In Morocco, for example, Lenz saw cowries as ornament on the daughter of a chieftain. Such ornament is also said to be used by the Tuarag of the southern Sahara, and, according to Nachtigal, by the women in Tibesti. The Joloff women string them on their hip-girdle. Clapperton saw cowries frequently on the fringes of the goat- and sheep-skins wound round the hips of the women of "Kufu," and at Wazo he saw them on the collars of greyhounds. According to Staudinger the Fulbes had their numerous hair-plaits frequently decorated with cowries. In Loko, Gurich, in 1885 , found children 
hung with cowry-shells. The men-folk of the pagan Kado negro in southern Haussaland, wear, according to Rohlfs, a skin-apron hung with cowries, and the young sirls of the Kedje negro fasten on their leather-girdles a bundle of small shells presented to them by their bridegrooms. Barth mentions shell-ornament as in use by the young women and girls of the Marghi, and in Bagirmi, by the pagan population in the south. The women especially wear such ornament of cowries, and caps too are made thereof, with which to decorate the heads of deceased relations. Nachtigal also states that in this neighbourhood, at the funeral of a chief, "a small gourd-shell full of beads and cowries was placed on the mouth in order to serve to some extent as travelling expenses." According to Rohlfs, the Mahommedan Aulâd Rashîd (Arabs in N.IV. Darfur) decorate the hair-plaits of their camels and horses with the porcelain-shells, and the women of Pebu adorn their arms with them. According to Nachtigal, the wood-or tin-trombone, about one and a half metres long, the hollowed antelope-horn, and the short pipes of wood, brass or horn, which emitted such terrible tones at festive processions of the Sheikhs in Bornu, were all adorned with numerous cowries on the surface. The Kawembu in Kanem and the Buduma of the islands of Lake Chad also wear neck-chains of cowries. The shells are a market-article in Kuka. They are taken as an article of barter in journeys from Kuka to Bagirmi and Wadai, where, especially by the native Arab and also by the pagan negro, they are used as ornament. The Mahommedan women in Bagirmi wear cowry neck-chains; the wives of the pagans in the Mofu district wear the shells on the girdle and apron strings. In Abeshr (Wadai), at the wedding of the king's daughter, thirty large baskets, adorned with shells or beads, were carried 
in front: Being wishful to journey through the pagan-land of Runga, Nachtigal provided himself with cowries. In Darfur he saw no more cowry-ornament." In Haussaland Robinson informs us: "The most common form of gambling is a game called by the natives chacha. It consists in throwing up five cowry-shells, the player winning or losing according as the shells fall, the right or the wrong way up." 100

Regarding the use of cowries in the region of the northern Guinea coast we have ample material to draw upon in the accounts of numerous observers. In Sierra Leone, at the time of Thomas Winterbottom, three or four necklaces of cowries were worn at the mourning for a wife, and the husband of the deceased woman was also required to wear a necklet of shells. According to Major R. G. Berry ${ }^{101}$ the shells are used to play a game called jagay, or knuckle-bones. They also form part of the sacred contents of the medicine bag, or Borfimor, used at the initiation ceremonies in connection with the Human Leopard Society of the Sierra Leone cannibals. A Borfimor bag obtained by Major Berry was found to contain four smaller bags, one of which held two taushaped iron crosses, the stems of which were lapped with cotton, and to the top of each was tied a cowry-shell, or sign of life. "The tau cross, or cmux ansata," Berry remarks -and in quoting this passage I do not accept all of the statements-" was the emblem of Osiris, and is called the Sign of Life, the symbol of resuscitation and new birth, expressive of the idea entertained by the Egyptians and

wo Schneider, op. cil, various pages (quoling Nachtigal, I3arth, and others).

100 C. H. Robinson, "I Iaussaland," London, I896, p. 206.

101 R. G. Berry, "The Sierra Leone Cannibals, with Notes on their Ifistory, Religion, and Customs." Proc. Roy. Irish Acadenny, vol. xxx., Sect. C., No. 2, May, 1912, pp. 45, 53, and 67. 
other philosophers, that nothing created was annihilated, and that to cease to be was only to assume another form, dissolution being mereiy the passage to reproduction. In its association with the Borfimor [and in this connection the presence of the cowry must. not be overlooked $]^{102}$ we seem to have the reflection of some such ideas, the fetish being animated by the indwelling life of the victim and the spirit attracted to it."

The Borfimor bag also contained a pebble made of some earthy matter and lime, in one side of which was incorporated a cowry-shell.

The remarkable resemblance in the use of the moneycowry here to that of the Ojibwa and Menomini tribes of North America, who also employ the same shell, has been pointed out already in a previous paper. ${ }^{10 ;}$

In Liberia, according to Stewart Culin, ${ }^{101}$ pierced cowry-shells (i.e., rubbed down on the back) are used in fortune-telling. (See Fig. E., p. I 56). Ratzel (op. cit., iii., p. 105) also gives a figure (f. 6) of a sword-sheath from Liberia which is ornamented with cowries arranged in stars.

Bowdich, who in 18 I 7 was sent on a mission of peace from Cape Coast Castle to Kumassi, mentions that in Accra, as in Gaman, Kong and other neighbouring places, cowries had currency.

North of Ashanti proper, in Koranza and Atabuobo, Perregaux found them in full use and of higher value than on the coast. According to this observer, in Koranza, they were counted per thousand, and Ioo cowries were

102 The italicized sentence is my own.

$103 \mathrm{~J}$. W. Jackson, "The Money Cuwry (Cyprec moneta, L.) as a Sacred Object among North American Indians," Manch. Memoirs (I,it. and Phil. Soc.), vol. 1x. (1916), No. 4. See also p. 184 of this chapter.

104 Culin, "Chess and I'laying Cards," op. cit., p. S15, footnote, and fig. I 34 on p. 8I7. 

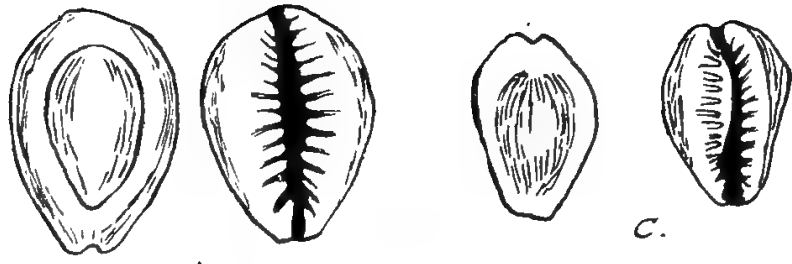

A.
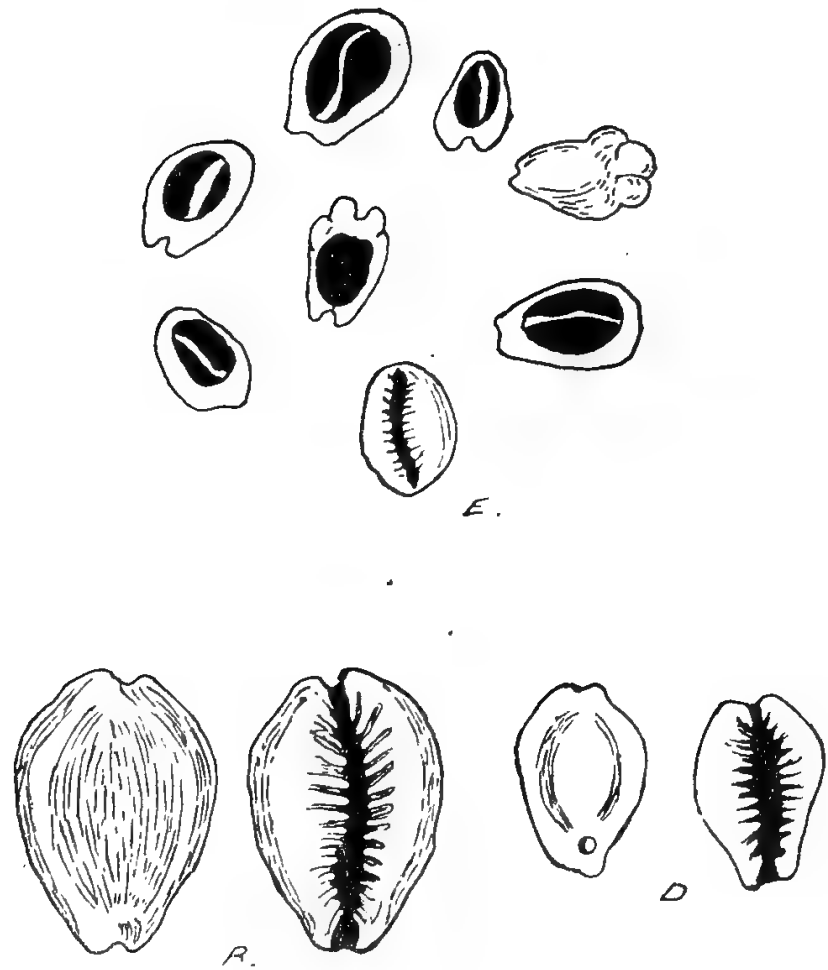

Cowries USED For CURRENCV, ETC.

A.-Cypriza anuulus (after Stearns).

B.-Cyprea monela (, ") ).

C. - C. moneta var. ataz'a Rochbr. (after Roberts in Tryon).

D.-C. moneta s.ur. atava liochbr, used by Ojibwa Indians (after IIoffman). E.-Cowries (C. moneta $v$ atava and v. ethnograplicica) used in fortunetelling, Liberia, Africa (after Culin). 
worth $3 \mathrm{~d}$. In Okwaon, on the contrary, they were reckoned thus :-

35 cowries $=\mathrm{I}$ string (Obang).

$\mathbf{I} 2 \times 35 \quad$ " therefore $\mathbf{I} 2$ strings $=3 \mathrm{~d}$.

$50 \times 35 \quad " \quad, \quad 50 \quad$ " $\quad$ ( 750 cowries $)=$ I Head

(Atramatiri).

In the plural, Atiri, was used for 2-9, and Atramatiri, for Io or more heads. A game with cowries (obviously the same game as elsewhere in this region) was named Atramaton, i.e. to throw cowries. These words are combinations with the word Atrama, which denotes cowries. "They were so named," says Perregaux, "in the Tshi language in Aquapim and Ashanti, while in Okwaon and the northern lands the designation Serevva was used. A single cowry was called Niwa, because of its likeness to an eye ${ }^{i 0 \overline{0}}$ (Oniwa), and ten cowries were called Niwandu." 106

Among the Mamprusi of the Gambaga country, north of Ashanti, cowries, together with kola nut, figure among the objects distributed to guests and musicians at wedding ceremonies. ${ }^{107}$

Apart from their use as currency, cowries play a very important role as amulets and in fetish-worship among the Ewe negroes of Togo district. They are worn on the neck, arm, wrist and ankle, and regarded as amulets against wounds and sickness, and for luck in hunting. Mischlich records that the hunt-fetishes, Gbofu of Dadease and Nakuku of Mjooti, both in Adeli, a district in the hill-country of Togo, were ornamented with cowries. Spiess mentions that they were worn in quantity by expectant women, to ward off danger. It was the custom among the

105 The likeness of the aperture of the cowry to the closed eye may explain why these shells have been applied as eyes for fetishes, etc., in the Congo region, Borneo, New Zealand, etc.

100 fide Schneider, op. cit., pp. 144-5.

107 "Women of all Nations," p. 344. 
Ewe that if a woman died in childbirth she was not given the usual burial treatment, and was not buried in her hut. The same shells are also employed as eyes in the Begbowo idol, as an ornament of the fetish-priests and priestesses at their dance, as offerings to the protective deity and at ordeals, at which it depends upon whether the priest, who has taken two or three cowries in the mouth, retains them there or casts them out. ${ }^{108}$ The similarity of these customs to those current in other parts of the zerorld is remarkable. As will be seen in the subsequent account, the association of the cowry-shell with pregnancy is to be found in places so far away as India and Japan; while the spitting out of cowries appears to be identical with the medicine ceremonial of the Ojibwa and Menomini Indians of North America.

According to Klose, Togo warriors wear caps ornamented with cowries. As a protection from evil small children have a pair of consecrated cowries interwoven in the hair, while the women of the bush-people of the hinterland fasten cowries as a fetish on the side of the head. Hunters, too, ornament therewith the butt-end of their flint-lock guns, in order to ensure success, and on a much honoured hunt-fetish in the neighbourhood of Soluga lay buffalo- and antelope-horns adorned with cowries. At the entrance to villages frequently stand clay-idols with cowry-eyes and shell-ornament, and in front of them lay abundant offerings of old spirit-flasks and calabashes filled with cowries. At ordeals for the detection of a murderer, the priests blow poison towards the sun out of a cowry-decorated pipe, which, when the suspicion is correct, falls down as blood, while at the trial of a thief two pieces of wood, adorned with a cowry at each end and wrapped round with a long cord, are made use of. ${ }^{109}$

10 Schneider, op. cit., pp. I69-I7o (quoting Mischlich and Spiess).

to9 Schneider, op. cit., p. I 7o (quoting Klose, "Togo."). 
In Togo-land cowries are also paid by the relations of a girl seeking admission among the Ewe-priestesses, and when the betrothed Ewe-youth brings his wife home he pays to her parents 4 marks in cowries. ${ }^{110}$ At death ceremonies, relations, friends and acquaintances, place quantities of cowries in the grave with the dead, in order that the deceased may purchase food and palm-wine, and reward the old ferry-man Akotia who carries him in his canoe over the wide river Assisa to the region of the dead. According to Monrad, ${ }^{111}$ the negroes fully believe that everything expended in the funeral obsequies, such as the goods, coral, cowry-money, etc., placed in the grave, the tobacco used and the wine drunk on such occasions, will be of use to the defunct when he rises up in the future world.

A mong the Bassari-people Klose found the previouslymentioned game of chance (cowry-throwing), at which he saw soldiers wager cowries to the value of from I to 3 marks at a cast. Cowry-casting for divination was also employed by the priests in the fetish-village Dadease.

According to R. Fr. Müller, at the circumcision of boys the circumciser receives a cowry, conveys it to the forehead of the person about to be circumcised, and finally buries it with the prepuce in a small pit; as a reward he receives $8 \mathrm{I}$ cowries. According to the same informer, cowries were offered to the small-pox fetish. ${ }^{112}$

That cowry-money has circulated in Togo for ages is proved by an old saying, handed down from generation to generation among the Ewe-negroes, according to which - cowries were found in a basket despatched from heaven

110 Herold, "Mitteil. aus den deutsch. Schutzgebeiten," Bd. V. (1892), p. 15 I (fide Schneider).

111 Monrad, "Gemälde der Küste von Guinea," p. II (fide Schneider).

112 Müller, "Fetischistisches aus Atakpama (Deutsch-Togo)," Globus, 1902, No. 18, pp. 280-I (fide Schneider). 
by Mawu (God), which the blacls eagerly appropriated for purposes of trade. ${ }^{113}$

In Dahomey similar customs to those of the Ewenegroes prevail. The famous Amazons of the king, who dwell in a house richly ornamented with skulls and cowrygarlands, have a custom of glueing a cowry-shell for each slain enemy to the stocks of their muskets, the shells being glued by means of the blood of the slain man. Another custom of the Dahomeyans takes the form of a "fight for cowries" thrown by the king and his Amazons, this being followed by the sacrifice of a human victim upon which cowries and other objects have been dashed. At the conclusion of these ceremonies a number of cowries are thrown upon the blood-stained earth. ${ }^{114}$

In Yoruba, as in Dahomey, cowries have been a recognised form of currency for centuries, and in recent years thousands of tons have been imported into Lagos. According to Hoffmann, in 1850 , about 40 white cowries (C. moneta) were equal to an English penny. In Yoemba, in Lander's time, it was the custom on the death of a chief for one of his wives to destroy all his possessions and shell-money and then destroy herself. On his travels through Yoruba, Lander also saw a sorcerer whose cowryhangings he estimated at 20,000 specimens. Not far off the river Mussa, Forscher saw a hut with a veiled entrance in which it was customary for passing negroes to place cowries, because the god housed therein gave them water, corn, and yams in abundance. ${ }^{115}$

Among the Egbas, according to Brown, ${ }^{116}$ it is the custom when a great man dies for slaves to be slain to act as his attendants in the land of spirits. Messengers

113 C. Spiess, Deutsch, Geogr. Blätter, 1899, p. 33 (fide Schneider).

114 Brown, "Races of Mankind," vol. iii,, pp. 92 and 100-2.

115 Schneider, op. cit., pp. 154-6, and 170.

116 Brown, op. cat., iii., pp. Ir4-I5. 
are also despatched to the dead in the same way. Slaves or prisoners taken in war are richly dressed and laden with cowries, and when they become intoxicated by rum they are slain. In this manner it is believed that not only messages, but the circulating medium with which the victims are laden, can be conveyed to the departed relatives of the people who have performed this pious sacrifice. With these people sixteen appears to be a sacred and mystical number. Thus, for instance, when meditating war the war priest throws into the air sixteen cowries. Much depends upon the way these fall. Those which fall with the aperture upwards portend peace; but if a greater number fall with their apertures downwards, then the divination is considered to be favourable to war.

Some interesting details of the use of the cowry as a medium for the transmission of messages are given by the Rev. C. A. Gollmer in his paper on "African Symbolic Messages." "17 In the Yoruba country, he informs us, the natives send messages to each other by means of shells, feathers, corn, stone, coal, etc., through which they convey their ideas, feelings, and wishes, good or bad. Cowryshells in the symbolic language are used to convey, by their number and the way in which they are strung, a variety of ideas. Thus one cowry, strung on a short bit of grass fibre, or cord, may indicate "defiance and failure"; two cowries, if strung face to face, "relationship and meeting," but if strung back to back, "separation and enmity"; two cowries and a feather, "speedy meeting"; three cowries, with their faces all looking one way, strung with an alligator pepper, "deceit"; six cowries may iridicate "attachment and affection."

According to Bloxam, ${ }^{118}$ cowries are similarly em-

117 Joum. Anthrop. Inst. Gt. Bu. and I., vol. xiv, p. 169.

x 18 Toid., vol. xvi., p. 295 . 

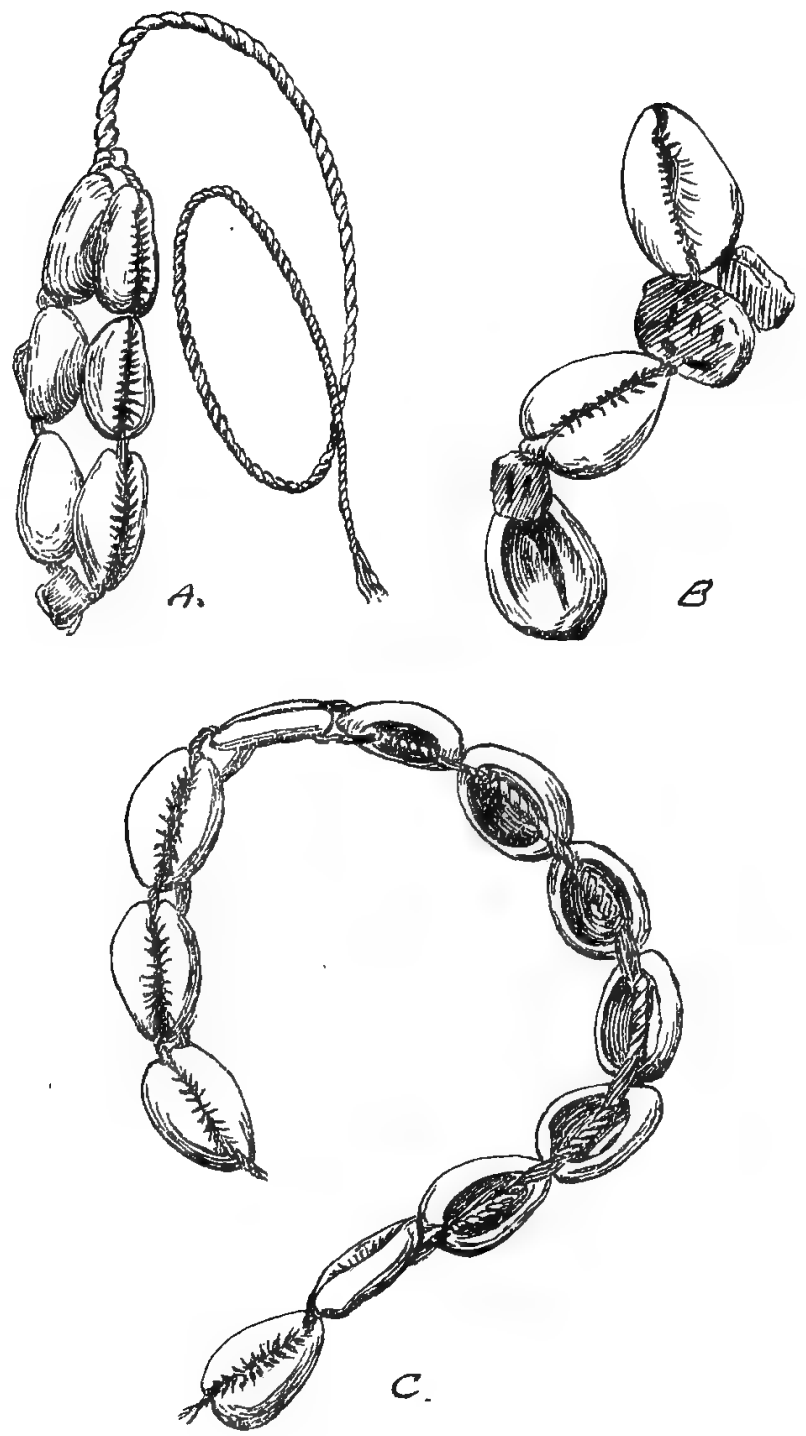

STRINGS OF COWRIES USED AS MESSAGES, ETC. A.-West African symbolic message (after Bloxam).

B. - "Amulet for protection," from Kafr Ammar, Egypt (after Petrie). C.-String of C. annulars from rubbish dating to xxi., dynasty. Medum (in Manchester Museum). 
ployed by the Jebu tribe of the west coast. The shells are strung together in varying numbers, odd numbers, as a rule, being of evil import, while even numbers express good will. A single cowry may be sent as an unfavourable answer to a request or message. In some cases other substances besides cowries are included in the aroko or symbolic letters. Thus we find pieces of spice, a piece of mat, and a feather, introduced for the purpose of conveying some significant idea. (See Fig: 4, p. 162).

This method of employing cowries for the purpose of conveying certain ideas is of interest in connection with discoveries made in Egypt of knotted cords with the same cowries, papyrus charm pendants, uzat eyes, etc., attached. Several of these cords are figured by l'etrie ${ }^{119}$ in his book on "Amulets," all from Kafr Ammar, xxiii-xxvth dynasty. He places the objects among amulets for protection and says no explanation of their meaning is known in Egypt. (See Figs. $B \& C$, p. 162.)

The history of the cowry in Africa may be concluded with a few remarks on its use in Benin and about the lower Niger. Dennett, speaking of the customs of the Bini, ${ }^{120}$ informs us that "the people swear by licking and touching stones, iron, cowries, bits of twisted rope, and the crushed leaves of a plant, asking these things to kill them if they are not telling the truth." According to the same authcrity, every great house has an altar to Olukun-the river spirit of Olukun or Great Benin river-in or near to which is a pot of water, cowries (Igo) and a heap of other objects. At Ewesi, not far from the Sobo plains, is a temple to Olukun, in which are very old wooden figures (like those into which nails are driven in the Congo) covered with cowries and other objects. In front of the 110 W. M. Flinders Petric, "Amulets," London, I914, P. 29, No. 13I, pl. xvii. -xix.

120 R. L. Dennett, op. cit., p. 193. 
great figure of Olukun himself sits a priest, half hidden by long strings of cowries hung from the roof. At Igo, a town on the Gilly Gilly road, there is a mound on which is an altar to Olukun with chalk cones and cowries on it, all covered by a shed. The presence of an Odigi, or sacred well, is generally made known along the roads by a tree and a mound of earth and cowries. ${ }^{12}$ The shells are also scattered at certain death ceremonies. ${ }^{122}$ Their association with marriage is seen by the fact that among the upper class cowries, together with kola-nuts and palm-wine, are given as presents on betrothal. "Often on the roads one passes a small tree planted by the side of the road, near which are chalk marks and a mound of earth, cowries, yams and plantains. This tree has been planted in memory of the fact that some woman or other has brought forth a child on that spot,"

On the Bonny river, at Ibo on the Niger, and in other places of the Niger-delta, cowries have, or had until quite recently, general currency. In this neighbourhood also it is the custom, at the interment of a chief, to bury all his treasure with him in the grave. The brothers Lander narrate that when they visited Idda, on the left bank of the Niger, much consternation and indignation prevailed, owing to the fact that the new chief had again exhumed and misappropriated for his own use the treasure of cowries which had been buried with his father. ${ }^{124}$

In India the money-cowry seems to have been regarded with special favour for amuletic and currency purposes from very early times. It has been met with on several pre-historic sites accompanied with bangles made from the sacred chank shell, Turbinella pyrum, and

121 Ibial., pp. 222-4, and 227.

122 Ibid., p. 207.

128 Ibid., pp. 198-9.

124 Schneider, op. cil., pp. $156-7$. 
other shell ormaments. Its association with chank bangles is specially interesting and seems to. imply a similar cultural source for the use of these white shells. Hornell in his work on "The Sacred Chank of India "125 informs us (p. 50) that fragments of Cyprea moneta and of a Nerita, also beads of entire Paludina shells, were found near Hampasagra, on the Tungabhacira, 53 miles west of Bellary, along with is fragments of chank bangles, Mr. Bruce Foote placing the age of this find as late neolithic or early iron age. Also (p. 51), "from made ground in the north bank of a nullah, at Huvina, near Hadagalli, 65 miles west of Bellary, came a single bangle fragment with two money cowries (Cyprea moneta)," and "from an old site north of Bellaguppa, came a fragment of a working section of chank shell, an entire Cyprea moneta, four fragments of scraper made of Unio shell, and three fragments of chank bangles; associated with these were a neolithic celt, a fragment of a corncrusher, some pottery, and two metal fragments, one being possibly part of a bronze ring." A further discovery of the money-cowry is recorded from Damnagar, Amreli Prant, Kathiawar, where two examples were found associated with a great number of fragmentary chank bangles, a basalt corncrusher, a bloodstone hammer, and chert and agate cores (Hornell, p. 57). The example of C. moneta figured by Hornell on plate V., (3456-13) is of great interest from the fact that the back of the specimen has been rubbed down in the characteristic Ancient Egyptian and East African fashion.

In dealing with the money of India prior to Alexander the Great, Del Mar (op. cit.) states that: "In Bengal the principal money finds have been of cowries, the metallic monies being comparatively few" (p, 66). And 
again (p. 90) in speaking of the standard of money in India from Alexander the Great to the Mahommedan Conquest, he says: "In Northern India the copper pieces were supplemented by gold and silver multipliers, in Southern India by dividers of cowrie-shells." In the Manikyala tope in the l'unjab, opened in I830, "were found mingled together cowrie shells, gold coins of the Kadphises and Kanerkes, Roman consular coins shortly before the Christian era, and copper coins of the Sassanian line."I" Cowries formed the bulk of the currency between the beginning of the Christian era and the Mahommedan dynasty of A.D. r203. ${ }^{12 \mathrm{y}}$ In Bengal the system of a copper standard with cowry dividers and gold and silver multipliers remained unchanged after the Mahommedan Conquest. Ibn Batuta, the A rabian traveller of the $14^{\text {th }}$ century, gives an account of the collection of the cowry-shells in the Maldive islands, from whence they were exported to Bengal in exchange for rice. He states that a bustus equalled a lak of cowries, and four laks, or four bustus, were estimated as worth one gold dinar, but the rate of exchange was so variable that occasionally a dinar would purchase as many as twelve laks of cowries. ${ }^{i \cdot 8}$

In Orissa, the next kingdom south of Bengal, accounts were kept in cowries, and the following scale of valucs prevailed during the early part of the Mahommedan rule : 4 cowries = I gunda ; 5 gundas = I boory; 4 boories = I pun ; $16-20$ puns $=1$ khawun ; 10 khawuns = 1 rupee. In 1740 , a rupee exchanged for 2,400 cowries; in 1756 , for

120 Marsden, "Numismata Orientalia," edited by Edward Thomas, London, 1874, quoted by Del Mar, op. cit., p. 86 foolnote.

127 Marsden, op. itt., p. 37 ; Del Mar, op. cit., p. go foolnote.

12: Del Mar, op. cit., p. 99; Edward Thomas, "The Chronicles of the I'athán Kings of Delhi," London, 187r, p. I Io foutnote. In Lee's translation of "I bn Batîta" (London, 1829, pp. I79 \& I81) the cowry (Wada) is referred to as alms-gifts and as currency in the Valdives. 
2,560 cowries; in $1833,6,400$ cowries; and in $1845,6,500$ cowries. Major Rennell, who was in Silhet in $1767-8$, speaking of the cowry'-money, remarks: "I found no other currency of any lind in the country; and upon an occasion, when an increase in the revenue of the province was enforced, several boat loads (not less than 50 tons each) were collected and sent clown the Burrampooter to Dacca." As late as r8or the revenues of the Britisl district of Silhet "were collected in cowries, which was also the general medium of all pecuniary transactions, and a considerable expense was then incurred by Government in effecting their conversion into bullion." (Thomas, op. cit., pp. I Io-i I f footnotes).

Lovell Reeve, in his "Conchologia Systematica,"13n mentions that " a gentleman residing some time since at Cuttack is said to have paid for the erection of his bungalow entirely in these cowries $[C$. moneta]. The building cost him about 4,000 rupees sicca ( $f 400$ sterling); and as sixty-four of these shells are equivalent in value to one 'pice,' and sixty-four pice to a rupee sicca, he paid for it with above sixteen millions of these shells."

In the Deccan, up to the thirteenth century, but few coins of any kind seem to have been minted, the currency appearing to consist almost entirely of cowries (Del Mar, op. cit., p. 108).

In early times, cowries, it is thought, were brought to India from the Philippines and Borneo, as well as from the islanci of Bima near Macassar (Celebes); in later times they were obtained from the Laccadive and Maldive Islands. Of the latter, the Arab Masudi, in the first half of the roth century, remarked that the queen had no other kind of money than the cowries, which were footnote.

12' Reeve, "Conchologia Systematica," London, I842, vol. ii., p. 262 
obtained by means of rafts made of the branches and lcaves of the cocoa-nut lashed together and floated on the surface of the sea. The work was carried out by women. When sufficient animals had become attached to the rafts by climbing aloft among the branches, these were dragged ashore and the shells spread out on the sands to enable the sun to dry up the contained animals. The Arab author, Ebn Beithar, who died in I 248 , also mentions the Maldives as a locality from which cowries were obtained. ${ }^{130}$ These islands are also referred to by Ibn Batūta, the Arabian traveller of the I $4^{\text {th }}$ century, who speaks of the use of cowries (Wada) there as currency and alms-gifts. ${ }^{131}$ At the beginning of the 17 th century, François Pyrard de Laval, observed the fishing of the cowries by the women of the Maldives. According to him they were collected twice a month, three days after the new moon and three days after the full moon. The shells were in such demand in India that sometimes 30 to 40 ships were seen loaded with them. In Cambay and other Indian places, the prettiest were used as ornaments along with silver and gold, and held as great rarities, as if they were precious stones. They also passed current there as money under the name Boly, and at burials they were scattered on the way from the house of the defunct to the cemetery as alms for the poor. ${ }^{1 ;-2}$ Captain Owen, in I $832,{ }^{133}$ gives an account of the collecting of cowries in the Maldives somewhat similar to that of Masudi. He further remarks on the similarity of the rafts, or balsas, to those used on the coasts of Chili and Peru.

Bengal seems to have been the great market for the cowries from the Maldives. From there they were widely

1 so fide Schneider, op. cit., p. 1 Io.

1 a 1 See Translation by Lee, op. cit., pp. :78 \& IS I.

13: Schneider, op. cit., p. III.

$1:=$ founn. Roy. Geog. Soc. Lond., vol. 2, 1832, pp. 8z-3. 
distributed over India, not only over the plains of the north and north-west, but also along the east coast and even to the slopes of the Himalayas and to the Deccan plateau. ${ }^{13 t}$

Besides their use as money in India the same shells are employed to ornament the trappings of horses and eleplants, as previously remarked. They are also strung like beads or sewed like buttons on the dresses of the Brinjari women of Nagpur province. ${ }^{135}$ According to Dr. Curt Boeck, they are tracled in Indian bazaars, especially for bordering the cloth-masks of shamans. ${ }^{1.16}$ In many Indian places, e.g., Gahsi, Punjab, one still finds C. anmulus worn by the native women. The Todas of the Nilgiri Hills, S. India, wear a C. moneta on a heavy silver collar (Schneider, op. cit., p. II 7 ). According to Thurston, this same species is also worn by Toda women on their thread and silver armlets and necklets. As in Africa, cowries are associated with Toda death ceremonies. When a person dies, various objects such as rice, honey, and other food-stuffs, together with cowries, "with which to purchase food in the celestial bazár," are burned with him. Like the Todas, the Kotas of the Nilgiris occasionally make use of cowries; they are sometimes seen on the neclilets of the women; and at funeral ceremonies when the skulls of the deceased are brought to the funeral ground to be burnt, a pole, twenty feet long, decorated with cowries, is also burned in the case of a male. The Nilgiri Irula women, too, sometimes have bead necklets with cowry'-shells pendent. ${ }^{177}$

1 * * Schneikler, op. cit., [p. In I.

1"s Stearns, "Ethno-conchology- A Study of l'rimitive Money," Report U. S. Nat. Dlus., I887, p. 302.

1: it Schneider, op. cil., pp. 1 6 6.7.

1:; E. Thurston, Hath as Government Mureum, fiulletin No. 4, 1896, pp. I 54, I74 ('Toulas), I92, I98 (Kotas); vol. ii., Xio. I, I897, pl). I4 and 16, pl. v. (Irulas). 
Thurston ${ }^{124}$ also cites a curious custom among the Chettis (trader's) of Southern India of unmarried girls wearing a neclilace of the money-cowry and beads, it being "unusual for unmarried girls to wear any badge of their condition." This association of cowries with the unmarried is of great interest in view of a somewhat similar custom in East Africa, to which reference is made on another page. Thurston further states that "when a Hasalara or Hasala (forest tribe) of Mysore dies, somebody's evil spirit is credited with the mishap, and an astrologer is consulted to ascertain its identity. He throws cowry (Cypran moneta) shells or rice for divination, and mentions the name of some neighbour as the owner of the devil. Thereupon the spirit of the dead is redeemed by the heir or relative by means of a pig, fowl, or other guerdon." (Thurston, op. cit., pp. I64-5).

Turning to Ceylon we find that Hildburgh, in his "Notes on Sinhalese Magic," ${ }^{139}$ states that cowries are worn as amulets by infants. This same writer also gives illustrations ( $\mathrm{pl}$. xi.) of masks worn by devil-dancers in which sometimes the upper, or both upper and lower, tceth are formed of cowry-shells. Culin, in his "Chess and Playing-Cards," 1+0 describes a cowry game, Kawadi Kelia, in which cowries of different kinds are used as men, each player also having three cowries as dice. This game is clearly related to the Hindu game of Pachisi, also played with cowries. The shells are thrown as dice and the counts are according as the apertures fall uppermost or not. "The game of Pachisi," says Culin, "may be

1 :s "E. Thurston, "Elhnographic Notes in Southern India," Madras, 1906, p. 68; In his article on "Some Marriage Customs in Suthern India" (Mairas Gout. Muss. Bulletin, vol, iv., No. 3, I903, p. I55), Thurston gives the species as Cyproaz arabica.

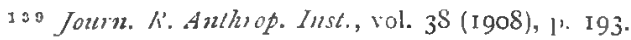

1\$0 lieporl U. S. Nat. .3/us., for 1896 (1898), pp. 851-4. 
regardecl as an expansion and elaboration of the type of game represented by the Korean $N y^{\prime} o u t$, and sacred and divinatory in its origin." Nyout is played with staves. "The two faces of the staves, black and white, may be regarded as signifying the dual principles of nature, masculine and feminine. A feminine significance is widely attributed to the aperture of the cowrie shell. Its convex side would naturally be regarded as masculine; hence its substitution for the staves would seem to have been an easy transition."

Games like Pachisi, in which cowries are used as dice, are known in the Mlaldive Islands under the name Dhola, and in Syria under the name of Edris a Jin; also in Burma as Pasit. ${ }^{1+1}$

In parts of Further India the cowry is still in circulation as money. In Siam and Laos it serves as a form of currency, and in the former country 6,400 cowries are said to equal about Is, $6 \mathrm{~d} .{ }^{1+2}$ At the end of the 17 th century La Loubère found it in use in all Siąn; it was obtained from the Laccadives, from Borneo and the Philippines, where it was taken in as ballast by the ships. About the middle of the 18 th century, according to Gervaise, the Siamese small-change consisted of small shells, which the Europeans called cowries and the Siamese Bia. According to Hertz they were no longer in use as small-change at Bangkok in I $88 \mathrm{I}^{1 \mathrm{1j}}$

In Burma the women of the Taungthas wear a loose skirt adomed with a wide belt of co'vries or silver filigree work. ${ }^{1+4}$

141 Culin, of cil., pp. 856-7.

142 Deniker, op. . il., p. 324 : See also "Century Dictionary," ii., p. I32I.

\footnotetext{
14: Schneider, of. cit, pp. Io7-\$.

144 "Women of all Nations," P. 5it.
} 
In Thibet, according to Carl Ritter, cowries serve as ornaments for women's girdles. ${ }^{145}$

Among the Khasias, a stone-using tribe inhabiting the Khasia Hills of Eastern Bengal, cowries are associated with marriage. According to Brown, "th "the marriage ceremony is of the most primitive type. All that is necessary is for the couple to sit together on one seat and receive their friends, to whom they give a marriage feast. A union so easily contracted is just as easily dissolved. The woman receives five cowries which she throws away; they are then free to be married again, the children remaining with the mother."

Among the Nagas of Assam, head-hunting was formerly a qualification for matrimony, and a warrior, having slain an enemy, had the privilege of wearing a kilt decorated with cowry-shells, collars ornamented with similar shells, tufts of goat hair dyed red, and locks of hair from the heads of the persons killed.43

A similar custom is prevalent among the head-hunting Patasiva of Seran, where a warrior is not allowed to take a wife until he can show the head of an enemy he has slain. In proof of his prowess the warrior wears as many little white shells (? cowries) round his neck and arms as he has murdered men. ${ }^{1+8}$ An even more striking identity in the association of cowries with head-hunting is to be found in East Central Africa, where the Djibba tribe wear not only the cowries but also the hair from the heads of the slain enemies see p. I 42 ).

its Scloneider, of. cit., p. II 7 .

146 Ijown, op. cit., iii., p. 302 ; quoting Lieut. Steel, K.A., Joum Ethnol. Soi, vii., p. 305. By some philologists the Kihasias are considered to be Thibetans.

14: " Women of all Nations," P. 58 I.

is G. A. Cooke, "System of Universal Geugraphy," vol. i. (ISoI), p. 609. 
Among the Dyaks of Borneo it is the custom to place the small white money-cowries in the eye-sockets of the skulls of enemies, which they keep. ${ }^{1+9}$ The baskets of the Dyak head-hunter are also decorated with the same cowries. ${ }^{150}$ Specimens in the Leiden Museum show $C$. annulus as decoration for sword-hangings from West Borneo, and $C$. moneti as decoration for a betel-pouch from South-east Bormeo. ${ }^{15 \mathrm{l}}$

In certain parts of Malaysia, cowries are attached to the fishing-nets, not as "net-sinkers" as recorded by several ethnologists, ${ }^{15 *}$ but in order to ensure success in fishing or to ward off evil influences. In Nias, an island off the west coast of Sumatra, Cyprea vitellus is so used; in Engano, an island in the same neighbourhood, the species is $C$. ventriculus; in Timor, C. arabica; while off N.IV. New Guinea the shells employed are $C$. moneta, C. coput-serpentis, C.eros, C. ly'n, C.tigris and C. vitellus. ${ }^{153}$

According to Von Martens, the Berlin Museum contains specimens of clothing ornamented with cowries, from Bali, near Java. ${ }^{15 *}$ In Timorlaut the natives adorn clothgirdles with cowries, and in the same island, four species of cowries, C. annulus, C. isabella, C. evosa, and C. helvola, are employed as neck-ornaments. ${ }^{155}$

Van der Sande, ${ }^{156}$ describes and figures several neckornaments from Dutch New Guinca, on which specimens

149 Stearns, op. cit., p. 302 ; Ralzel, op. cit., i., p. 135 (ig.).

150 Ratzel, op.cit., vol. i., p. 448 (Gg.)

151 Schmeltz, "Schnecken und Muscheln in leben der völlier Indonesiens und Oceaniens," Leiden, 1894.

132 The slight weight of these shells would render them valueless as sinkers.

15 s Schmeltz, op. cit.

15 4 Schneider, op. cit., p. II8.

105 Tbid., and Schmeliz, op. il.

150 Van der Sande, "Nova Guinea," iii, I907, pp. 83, 1I7.8, pl. xiii,, fig. 4 . 
of C. anmulus are strung on strips of Pandanus leaf, the whole hanging down from a neck string in front of the chest. Schmeltz (op. cit., pp. 23 et seq.), also cites the use of $C$. argus and $C$. lyn as breast-omaments, and C. moneta on hip-strings in N.E. New Guinea; C. moneta on arm band, $C$. annulus as leg-and shield-ornaments in S.E. New Guinea; and $C$. monetr as ankle-ornament in N.IV. New Guinea.

In the Philippines, according to Schmeitz (op. cit.), C. annulus is used as a neck-ornament, as decoration for the coat-of-mail of the Moro, and as the eyes of ancestorimages.

According to Pickering the cowry was formerly in use as money in the Hawaiian Islands. He says ${ }^{1 \overline{\bar{t}}}$ : "An estimable and intelligent Hawaiian lady gave me the following particulars respecting former customs:

Money was certainly known, for with a string of cowries i (yprica moneta) it was possible to buy any article wanted. Specimens of the same shell that were finer than usual, having a high polish and deep yellow colour, were extravagantly valued, and could only be worn by the highest chiefs, who also exclusively possessed wooden calabashes." In the Vancouver collection, British Museum, are I.cis of Cyprea moneta from these islands. ${ }^{159}$

In Oahu, Hawaii Islands, a large cowry, Cypreea mauritiona, is attached to fishing-nets in order to ensure success. Specimens of this are in the R. D. Darbishire collection, Manchester Museum. The stone (lava) "net-sinkers" of Oahu are curiously enough all modelled after this shell, being roughly carved with a high round back and flat base, with a groove for the attachment of a cord.

157 Pickering, "Races of Mian" (Bohn's Ed.), I863, quoted by Stearns, op. cil., p. $3 \mathrm{O}_{3}$. i., p. 43 . 
Cyprea monetr appears to have been current also in other islands of the Pacific, as Brenchley states: "At Eramango [New Hebrides] a shell called 'Nunpuri,' the Cyprea moneta, passes as money, as also in New Caleclonia."

In the Bismark Archipelago, says Schneider (op. cit., p. II8), C. annulus was found as money in special cases.

In Gilbert Archipelago, the Ellice and Kingsmill Islands, Cyprea moneta and C. anmulus are used as bodyornament and for decorating implements and tools. ${ }^{100}$

F. W. Christian, in his article "On Micronesian Weapons, Dress, Implements, etc,"1k1 figures a cowry-shell used in the Carolines for stripping off the outer skin of the bread-fruit. The figured shell looks like a $C_{y p r e a}$ manritiane. He also figures an Ounlum ovum shell (often alluded to as the white cowry) pierced for ornamenting prows of canoes. The use of this shell as a canoe-ornament is general throughout the Pacific. Amongst other places it is recorded from the Pelew Islands, Yap, Gilbert Archipelago, Samoa, Niné, Viti Islands, Solomon Archipelago and Torres Straits Islands. In some of these and in other islands it is also woin as an ornament for the neck, breast, or leg, and placed on the outsides of native houses. In Tonga it is used as a graveornament, and in the Solomons as decoration of an idol. ${ }^{163}$

In Tahiti, Cyprea moneta and C. talpa are worn on the neck, and $C$. tigris occurs on the base of an idol from Tahiti, now in the British Museum." Sir C. H. Read, in his description of specimens obtained on Vancouver's

15: Prenchley, "Cruise of the "Curaçoa," "I873, p. 299, quoted ly C. Hedley, Mem. Aust. Mtus., iii., pt. 7, r899, p. 452.

1: Schneider, op. cil., p. I 8 .

1;1 /. Anthrop. Inst., 28 (1898-9), pp. 288 et seq., pl. xxiv., f. 5.

1 o 2 Schmeltz, "Schnecken und Muscheln in leben der völker Indonesiens und Oceaniens," Leiden, 1894.

I s 3 loid. 
voyage, figures an instrument of palm-wood, used for splitting bread-fruit in this island, to which are attached two tiger cowries with their inner whorls broken out, and one end cut off. ${ }^{164}$

In the Loyalty Islands, the orange cowry (Cjpraca aurora) is greatly valued. The Rev. Mr. Hadfield, in the course of his missionary work, came across a fine specimen in a native hut in Lifu, where it was held in much veneration by the occupant, who considered it a kind of fetish. ${ }^{165} \mathrm{Mr}$. Hadfield also gives us some further interesting information regarding this species. Ife tells us that his wife came upon a specimen which, according to the native report, had been found by an old woman who was struck on the forehead by a demon, who asked ler why she took the shell. The womall, it is said, died from the effects of the blow. ${ }^{166}$ This fine shell is used as a badge of high rank in Tonga, or Friendly Islands, as well as in Fiji. One of the most remarkable Fijian industries is the working of whales' teeth to represent this cowry, as well as the commoner $C$. talpa, which is more easily imitated. ${ }^{167}$

The New Zealanders, it is stated, use Cypraa asellus and other shells to form the eyes of their idols. ${ }^{168}$

Codrington, in his "Melanesians" (Oxford, I 89I, p. 26), tells us that in Aurora, the nearest of the New Hebrides to the Bank's Islands, the natives have a story that the first woman came from a cowry-shell. Somewhat analogous ideas are expressed in the traditions of the Samoans as to the origin of man. By these people it is believed

104 T. Anthrop. IIrst., 2I (I891-2), pp. I05-6, pl. x., f. 5.

ics Melvill \& Standen, "Lifu Mollusca," Journ. of Conchology, viii., I 895 , p. I12.

1 so Tbid., p. I3I.

107 A. H. Cooke, "Molluscs," Caml. Nat. Hist., iii., I 895 , p. 98.

ios Ibid., p. 99. 
that man is formed from a species of mussel and that gods are present in some of the shell-fish. ${ }^{169}$ A similar idea concerning the possibility of human beings living in shells is current among the Indians of the N.W. coast of America. According to the Haida and Kaigani the first people sprang from a cockle-shell. ${ }^{170}$

In the Far East, cowries, both large and small, were used as a medium of currency long before the Christian era. Frequent allusions are made to them in ancient Chinese literature, but the authenticity of some of these records and of the dates assigned to the period when cowries were in use is open to some criticism. M. Terrien de Lacouperie ${ }^{171}$ has presented us with some remarkable views on the origin of Chinese civilization, based upon the study of numerous Chinese works, and from his statements it would appear that cowries were used as money in China as early as 2,000 years B.C. But the fact that many of the works which he studied are, to a large extent, based upon tradition renders them unreliable as evidence as to date. It seems certain, however, that cowries were in circulation among the people of Eastern China in the seventh century B.C., and the southern country of Ts'u figures largely in connection with supplies of these shells for currency. Contact with the west through seatraders of the Indian Ocean (Erythrean Sea), who are claimed to have established a colony in the Gulf of Kiaochou (South Shantung) in 675-670 B.C., had made them familiar with many western practices, and it is not improbable that the use of the cowry was one of them. Some time about 600 3.C., the king of Ts'u issued two

160 Turner, "Samoa, etc." London, I884, pp. 8, I2 and I7.

170 Niblack, "The Coast Indians of Southern Alaska and Northern British Columbia," Rept. U.S. Nat. Mus., I887-8 (1890), p. 378.

171 Terrien de Lacouperie, "Western Origin of the Early Chinese Civilisation from 2,300 B.C. to 200 A.D." London, 1894 . 
sizes of small coins, bean-shaped (in the fashion of the Eginatan and Lydian coins of 750-700 B.C.) and inscribed with their respective weights. These coins are known in native numismatics as metallic cowries, Ho-pei tsien, because their shape suggested that of the once useful little shells they superseded. They have also received other quaint appellatives, as 'Ghost-heads,' K'wei-tou; 'Ghost-faces,' Krevi-lien; and 'Ants'-noses money,' $Y$-pi. tsicn. ${ }^{372}$ The introduction of this and other metallic currencies caused the circulation of cowries to disappear gradually in eastern China, and in B.C. 221 , the king of Ts'in, having assumed the title of She Hwang-ti, "the first universal Emperor," issued an order forbidding henceforth the use of gems, pearis, tortoise-shells, cowries and tin for currency purposes. Cowries, however, still continued to be regarded as objects of appreciation; and in B.C. I 79 we find the king of Nan-yueh sending as presents to the Chinese emperors 500 purple cowries ${ }^{173}$ along with other gifts. At the end of the First Han dynasty an attempt was made by Sin Wang Mang, the usurper (A.D. 9-22), to revive the circulation of cowries and tortoiseshells, but little success rewarded his efforts. According to Lacouperie, ${ }^{171}$ the cowry currency consisted of five sorts, regulated as follows :-

"(I) The great shells; 4 tsın or inches, 8 fen or Ioths in length; two of which formed a pang or pair; value 216 cowries.

(2) The bull shells; 3 tsun, 6 fen in length; a pair of which was worth 150 cowries.

1; L Lacouperie, op. cit., p. IIS; also "Catalogue of Chinese Coins in British Museum." London, I892; and "The Metallic Cowries of Ancient China, 600 B.c.," Joum. Roy. A siatic Soc, xx., I888, pp. 428-439.

1: 3 The money cowry, $C$. moneta, before becoming fully adult, has a deep purple back, and probably these were the objects sent.

17 t Lacouperie, of. cit., I\$92, p. 382 . 
(3) The small shells; 2 tsunn, 4 fen in length; a pair of which was worth 30 cowries.

(4) The lesser shells; I tsun, 2 fen in length; a pair of which was worth 10 cowries.

(5) The smallest shells (cyprea moneta, or cowries), being smaller than I $t \operatorname{sun} 2$ fen, were not fastened in pairs; each was worth three cash. Those which were smaller than six fen were not used for currency."

The shelis of groups I to 4 seem to have been undoubted cowries, as in group 5, only larger, as the same characteristic Chinese hieroglyph denoting cowry (see Fig. C, p. I80.) appears against each of the groups.

Unfortunately, except for dimensions, the particulars are lacking as to the species of cowries forming these four groups.

If we may take the measurements as more or less approximating to English inches, it is possible to find a series of cowries inhabiting Eastern seas which would come within these dimensions. For example, Cypraa testudinaria (the "tortoise-cowry," named by Linnæus from its resemblance to the tortoise) might very well have served for group I. Of the others, group 2 may have been smaller examples of the same, or even Cypraa tigris; group 3 may have been Cyprea lynx; while group 4 were probably exceptionally large examples of Cyprcea moneta. The average length of the latter species is about one inch.

Regarding the tortoise-shells re-issued by Wang Mang, Lacouperie informs us that "there were four different sorts, of various sizes and denominations, with different values, but the details have not yet been handed down to our time." It is not a little curious that the larger cowryshells were also of four different sorts, sizes, and values. 


\section{提果 III!}
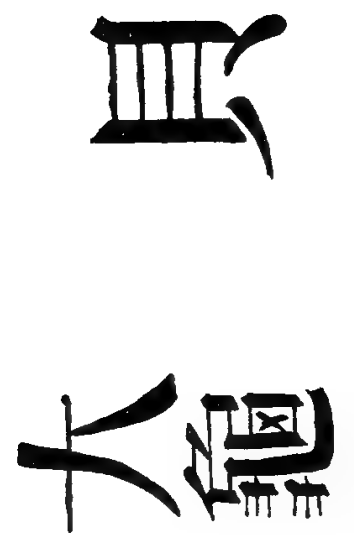

v
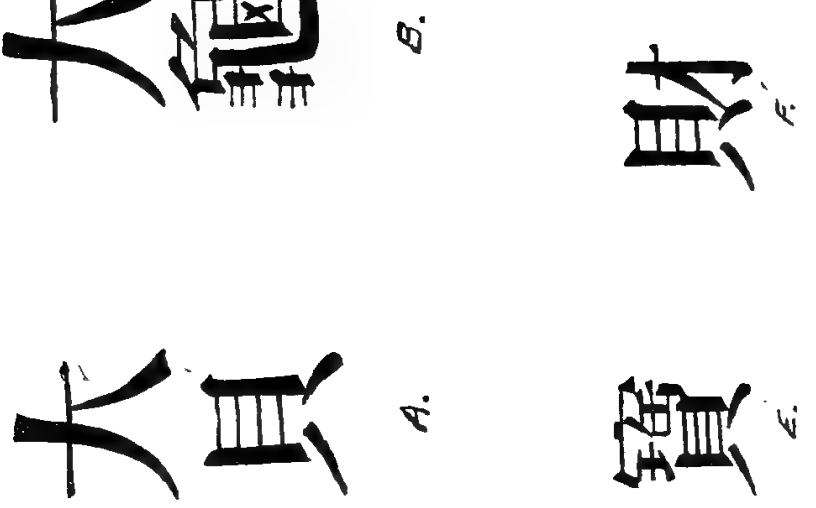

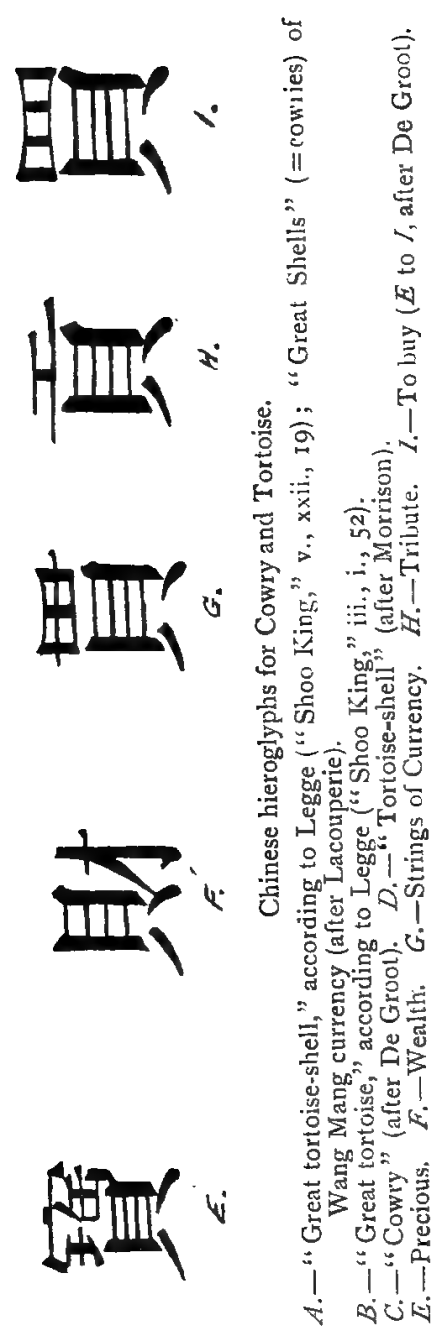


This suggests the possibility of the so-called "tortoiseshells" being really cowries.

From the following facts it is obvious that some confusion has taken place with regard to the interpretation of certain symbols in ancient Chinese works.

In Dr. Morrison's "Dictionary of the Chinese Language " ${ }^{1765}$ a symbol known as pei (see Fig. C, p. I80), is translated (p. 622, No. 847I) as "the tortoise shell or pearl-oyster shell": on an earlier page (p. 5 ro, No.68ri) quite a distinct symbol, kzeri, is translated "tortoise," and the pei symbol is attached to denote "tortoise shell"krvei pei (see Fig. D, p. 180).

In a Chinese work, the "Li Ki," or "Treatises on Ceremonial Uses" (referred to on a later page) the pei symbol (Fig. C, p. I 80) is used to denote a particular object placed in the mouth of the dead. The symbol in this case has been correctly interpreted by the translator of the work as meaning "cowry."

In the "Shoo King" (v., xxii., I9), the same symbols (Fig. $A$, p. 180) as quoted by Lacouperie for the "great shells" (i.e., cowries) of the Wang Mang currency, are used in a paragraph describing a display of various precious relics. But these characters have been translated by Dr. Legge, in his "Chinese Classics," "176 as the "great tortoiseshell."

The "Tribute of Yu" ("Shoo King," iii, i., 52) refers to a particular object presented to $Y$ ü from the country of the nine Këang, the symbol denoting this object being the Kwei (No. 68Ir, p. 510) of Morrison's Dictionary (Fig. B, p. 180). It is here translated by Legge as "the great tortoise." ${ }^{157}$ In his footnotes to this passage the translator states that " according to the 'Historical Records' the

176 Dr. R. Morrison, "Dictionary of the Chinese Language," I 8 I9, vol. i., pt. ii.

17 Dr. J. Legge, "Chinese Classics," I 865, vol. iii., pt. ii, p. 554.

177 Tbill., vol. iii., pt. i., p. II6. 
great tortoise attained the size of two cubits and a half. Such a creature would be esteemed very valuable, where divination was much relied on"; and further, according to Gan-Kwo , that "the tortoise was not a regular article of tribute, but was presented when required by express command."

In the "Pwan-Kang" ("Shoo King," iv., vii, If), the characteristic symbol, pei (Fig. C, p. I 80) occurs in a passage dealing with the hoarding propensities of government officials, and is here translated by Legge as "cowries."

From the above remarks it will be seen that the $p c i$ symbol has been incorrectly interpreted in certain cases.

Some interesting particulars concerning the use of cowries in connection with the dead are given by Dr. J. J. M. de Groot, in his work on "The Religious System in (hina." ${ }^{179}$ The ancient Chinese, he tells us, used several precious articles for preserving their dead. To this end they availed themselves of cowry-shells, which were so valuable in ancient times for currency. This fact, well known to Sinologists, is especially manifest in the ancient hieroglyph denoting the cowry (see Fig. C, p. I80), which enters into the composition of most characters signifying things of value and acts connected with trade and barter (see Figs. E, F, G, H, I, p. I8o).

These shells were used in association with rice for stuffing the mouth of the dead. They were made to support the last molar tooth on the left and the right side, and the mouth was finally filled up with rice.

According to the "Li Ki," or "Treatises on Ceremonial L'sages" (an important source of our knowledge of China during pre-Christian times), the mouth of the Son of Heaven was stuffed with rine cowries, that of a

it s Ilid., iii., pt. i., p. 240.

1 to Vol. i., bk. i., "Disposal of the Dead." Leyden, I892, pp, 275.6. 
feudal lord with seven, that of a great officer with five, and that of an ordinary official with three. ${ }^{\text {I.11 }}$

In some of the out-of-the-way corners of China cowries remained in circulation for many centuries. In Marco Polo's time (A.D. I27I-9I) cowries, called "porcellani" by this traveller, were still in use in the country of Yunnan, the shells being gathered at the group of islands now known as Pulo Condore, off Cochin China. ${ }^{181}$

In the I6th century the cowry-currency seems to have been officially suspended in Yunnan province. At the present time cowries appear to have completely lost their money value in Yunnan, since Lieutenant Garmer found them nowhere in use north of Luang Prabang, Laos; and in western Yunnan they were worn only as ornament by the Kakhyens. Carl Bock likewise saw cowries on the head-masks of the leaders of the mule-caravans which come from Yunnan into northern Further India. ${ }^{192}$

It is doubtful whether the cowry was used as currency in Japan, though it is possible that in olden times shells from the neighbouring Liu Kiu Islands were so used. The Japanese name, Takara (=prosperity, riches), kai or $s^{g} a i$ (=shell), may indicate their use as money. In Kampfer's "Description of Japan" (London, 1727, Bk. i., ch. ii.) appears: "Takara gai, called Kauri in India, brought from the Maldives and other islands and imported into Bengal, Pegu and Siam, where it serves as current money." K. Florenz reports that the Japanese women at their confinement hold in the hand a "Koyasugai (Easy-delivery-shell), a species of cowry," in order to ensure certain and easy delivery, a practise analagous to

1su fide De Croot, of. cil., p. 275.

Is 1 Colonel IIenry Yule, "The Book of Ser Marco P'olo," London, is 7 r, vol. ii., pp. 39 et seq.

182 Schneider, op. cit., p. Io7. 
that of other peoples, e.g., the Indian. ${ }^{1 w}$ Attention has already been called to the similarity of this custom to that of the Togo people of West Africa.

The money-cowry (Cupria moneta) is, and has been for centuries, a sacred object among the Ojibwa and Menomini Indians of North America, and is employed in initiation ceremonies of the Grand Medicine Society. ${ }^{184}$

The use of this particular cowry by these Indians is of peculiar interest; in the first place; owing to it being alien to the American continent, and in the second place, in view of its intimate association with so many remarkable and fantastic beliefs and practices in different parts of the Old World.

The tradition among the Indians is that the original sacred shell-ming $\bar{z}^{\prime}{ }^{1}{ }^{1 *}$ of the Ojibwa; konäpamik, of the Menomini-was introduced by a particular hero-god, who acted as an intermediary between the Great Unknown and the Indians, and founded their Medicine Society. Among the Menomini the sacred shell appears always to be the small white money-cowry, Cyprea moneta, ${ }^{186}$ but among the Ojibwa, according to Hoffman, it consists of a small white shell, of almost any species: but the one believed to resemble the mythical $m \bar{z}^{\prime} g i$ is similar to the money-cowry. This fact would seem to imply that the money-cowry is scarce among them, and those they possess, doubtless handed down from generation to generation, are regarded with special veneration as being like

is a Schneider, op. cit., p. 108.

18* W. J. Hoffman, Bureau of Ethnolog!' (United States), 7th Annual Report, 1885-6 (I891), and I4th Annual Report, I892-3 (r896), pt. i. ; also 1. W. Jackson, Manch. Aremoirs (Tit. and Phil. Soi.), vol. Ix. (19I6), No. 4. Abstract in Nature, January 27th, 19i6.

196 In the Ojibwa language, $\mathrm{m}^{-} \mathrm{g} g$ is $=$ symbolical of life.

1s: The example figured by Hoffman (op. cit., IS9I, pl. xi., fig. I) is interesting, as it is perforated at one end as if for suspension; it is of the dwarf var. ataz'a of C. monela (see Fig. D, p. I56). 
that which came into their possession tbrough the herogod Mî́nabözho.

The initiation ceremonies of these Indians are very elaborate: the most important incidents are dancing and the shooting forward by the medicine men of their skin medicine-bags containing the sacred cowries. Mystic powers are attributed to the shells, and it is firmly believed that if they be swallowed by the medicine man, he can transfer his power to the medicine-bag by breathing on it, the mysterious influence being then conveyed to the desired object or person merely by thrusting the bag forward in the appropriate direction. At the initiation ceremonies the magic influence is shot at the candidate's breast, and the cowry-the symbol of life-is supposed to enter his heart; he becomes unconscious and falls forward on his face. The chief medicine man then raises the candidate's head slightly from the ground, and a sacred cowry drops from the candidate's mouth.

The same cowries apparently play an important part at baptismal ceremonies of the Ojibwa. There is much dancing and the same shooting forward of the medicine basss, and after a good deal of facial contortion each medicine man spits out two shells on to a cloth spread in the middle of the medicine tent. ${ }^{147}$

The essential part of these ceremonies is the supposed death and survival of the candidate, the whole ceremonial being strongly reminiscent of the St. George, or Mummers', Plays of the Old World. ${ }^{18}$ It is remarkable how closely the prevailing idea of the cowries being connected in some strange manner with resurrection and resuscitation agrees P. 24 .

$1 \backsim$ James Greenwood, "Curiosities of Savage Life," London, 1863 ,

is "For a full discussion of this subject see A. Beatty, "The St. George, or Mummers' I'lays; A Study in the P'rotology of the Drama," Trans. Wisc. Acut. Sci. Arts and Letlens, xv., pt. ii., Oct., 1906. 
with the ancient Chinese belief as evidenced in the ceremonial use of money-cowries in obsequies of the dead. As mentioned previously, in pre-Christian and later times, cowries were used in China, in association with rice, for stuffing the mouth of the dead. Wild rice, it might be added, also enters into the ritual of Ojibwa and Menomini ceremonies. The fact that the so-called "wild rice" of America is not identical with true rice cannot be raised as an objection to the identity of these practices: for the similarity which suggested the name "wild rice" to European immigrants in America no doubt appealect with equal force to the earlier Asiatic rice-using immigrants.

The apparent identity in the spitting out of corvies by the Togo priests of West Africa and by the medicine men of the Ojibwa and Menomini Indians has been noted already. The association of the money-cowry with the medicine bags used by the Sierra I eone cannibals at initiation ceremonies is a further remarkable parallel.

Some interesting evidence of the early use of the money-cowry in North America is contained in an exhaustive account on "Aboriginal Sites on Tennessee River," by Mr. Clarence B. Moore. ${ }^{\text {1n? }}$ In his description of the Roden Mounds, Marshall County, Alabama, this author informs us that in Burial No. 44, well in the body of mound $A$, were the remains of a skull, near which were fragments of a large marine univalve, and five shells, some much decayed, which had been pierced for stringing, like beads. These are pronounced by Dr. H. A. Pilsbry, the well-known American conchologist, to be examples of the money-conry, Cyprea moneta, of Eastern Seas. Such shells have never been recorded before from an aboriginal mound in the United States. The careful investigation of the Roden mounds indicated that they had been built

is a Journ. fiad. Nat. Sir. Mhilad., and Ser., xvi., pt. ii., 1915. 
before their makers had any intercourse with white persons. The presence of the cowries, therefore, is of special interest.

The shells were sent by the discoverer to Dr. IV. H. Dall, another of America's leading conchologists, and the following extraordinary statement was received in reply :-

"I should incline to the belief that the cowries were imported in or about the time of Columbus' voyages. Bound, as they supposed, for the Indies, where the cowry was formerly (like our wampum) a staple article of barter, the exploring vessels would undoubtedly have carried cowries as well as the other articles of trade we know they carried. It would not have taken them long to find out that cowries did not pass as currency with American natives, and reporting this on their return to Spain later traders would not have carried them for barter. The necklace or bracelet you obtained may have passed from hand to hand as a curiosity (as I have known such things to do) until it reached a people who knew nothing of the whites 'till much later. In fact your cowries may have come off one of Columbus' own vessels!"

But an even more remarkable story is that given in "Harper's Monthly Magazine" for September (1916, p. 599), by Mr. H. Newell Wardle, of the Philadelphia Academy of Natural Science, as follows :-

"The great Genoese, starting in 1492 on his irst voyage to discover a new route to the kingdom of the Great Khan, doubtless stocked his ships with a goodly store of these ivory-white porcelain shells. He had been in Guinea. He knew the requirements of the Gold Coast trade . . . . P'robably, though he fails to mention it, cowries, strung as for the Guinea trade, were part of his stock-an ill-venture, in competition 
with the shell ornaments of the Gulf Coast. . . . So mayhap the five little shells were bestowed, by Columbus's own hands, upon a native of the isles, were carried across to the mainland on some trip of trade or of pleasure, and thence, from hand to hand, as curios, journeyed northward with an ever-growing wonder-tale of the great white chiefs from the East. . ."

"If not thus, then they had journeyed in dangling from the trappings of one of those noble steeds that shared the perils of the early explorers of the mainland. ..."

"Certain it is that they date from the close of the fifteenth or the early days of the sixteenth century."

But Mr. Wardle omits the most wonderful episode of his wonder-tale-I refer to the fact that after all these imaginary wanderings and episodes on sea and land, the cowries should eventually have come to rest in the heart of the American continent, and, " of course purely by accident," have become linked up with the identical beliefs and fantastic practices with which they are associated in Africa, India and Eastern Asia!

To such lengths does the American ethnologist go rather than admit the patent fact that these shells and the associated beliefs and practices were taken from Eastern Asia to America long before the time of Columbus!

According to Mr. Charles C. Willoughby, the Peabody Museum, Cambridge, Mass., contains a dress of a Cree woman, collected by the Lewis and Clark Expedition in ISO4-5, on which are four dozen cowries (see American Anthropologist, 1905, for picture of the dress).

The shells from the Roden mound, Moore informs us, "differ from those on the Cree dress, which are of a larger variety and much more distinctly humped than are our 
shells, ours being of the variety atava, as described by Rochebrune, ${ }^{100}$ who says they come from the Cape Verde Islands" (see Fig. C, p. I 56).

Notwithstanding Rochebrune's assertion, few students of Cyprea admit the possibility of the occurrence of living C. moneta at the Cape Verde Islands, or indeed on any portion of the West African coast. The cited occurrences there of this and the allied form, C. annulus, may be due to accident. As already stated, enormous numbers of these shells have been carried to this coast during the last few centuries, and it is a well-known fact that ships conveying this commodity have occasionally come to grief, the cargo of shells being lost. Such an occurrence is recorded to have taken place in the year 1873 , when the "Glendowra," a four-masted barque, homeward bound from Manilla, was wrecked off the coast of Cumberland. The "Glendowra" had on board some 600 bags of cowries (C. moneta and C. annulus) and missed the port of Liverpool through an error in her course, and, in the fog which prevailed, ran ashore near Seascale. For years these shells have been picked up, in good condition, on the sandy shore between Seascale and the river Calder, and collectors, unaware of their history, have regarded them as indigenous to the British Isles. ${ }^{191}$

Unfortunately, the precise distribution of the numerous varieties of $C$. moneta is not very well known. Hence it is not possible to be sure of the exact provenance of the Roden mound cowries, nor of those on the Cree dress. It may be of interest, however, to note that Dr. J. Cosmo Melvill, in his "Survey of the Genus Cypræa" (op. cit., p. 240), gives India as a locality for the var. atava.

190 Bull. Soc. Malac. de France, i., 1884, p. 83, pl. i., fig. 4 (copied in Fig. $C$ of the present Chapter, p. 156).

191 See The Naturalist, London, Nov., 1890, p. 324. 
Mr. IVilloughby believes that cowry shells were sold to the Indians by the Hudson's Bay Company late in the eighteenth or early in the nineteenth century.

Prof. Henry Montgomery ${ }^{192}$ records and figures a cowry found near the so-called Onatonabee Serpent Mound, Peterboro County, Ontario. Mr. C. B. Moore, (op. cit., p. 295) says: "The shell described by Professor Montgomery is a regular Cyprcea moneta, or money cowry of Africa and the East, and not a California sheli. This shell, which, by the way, is not pierced for stringing, is probably one from the Hudson's Bay Company stock. We do not think the sale of cowries to Indians in the North at a comparatively late date by the Hudson's Bay Company indicates a relatively recent origin for the Roden mounds, for, at a period when the supplies of the Hudson's Bay Company could have reached the makers of the Roden mounds, articles of European make could have got among them from all directions and the mounds presumably would have been well supplied with glass beads, brass, iron, and other things obtained from European sources which, as we see, was very far from being the case."

In an old account by G. A. Cooke, ${ }^{193}$ dealing with the habits and customs of the Indians of the most northern parts of America, some interesting particulars are given conceming the ceremonies observed by certain tribes previous to waging war. One of the most hideous of these, Cooke informs us, was the setting of the war-kettle on the fire, as an emblem that they were going out to devour their enemies. A porcelane, or large shell, was then dispatched to their allies, inviting them to come along and drink the blood of their enemies. Unfortu-

192 Trans. Canad. Tnst., Toronto, 19ro, ix. (i.) No. 20, p. 7, pl. iv., fig. 6 (fide $M$ loore).

123 Cooke, op. cit., ii., p. 2 I. 
Use of Cowry-shells for Currency, Amulets, etc. I9 I

nately, neither the name of the tribes concerned, nor the name of the shell employed, are given; but the fact of the latter being called a "porcelane" is not without interest, as "porcelaine" is the common French term for cowry. There is no certain evidence, however, to support the conclusion that a cowry was the shell employed as a war signal. Earlier in this Chapter we have seen that when the Egbas of West Africa meditated war, cowries were thrown into the air by the war-priest; and in the Yoruba country, where cowries are used for symbolic messages, a solitary cowry indicates defiance.

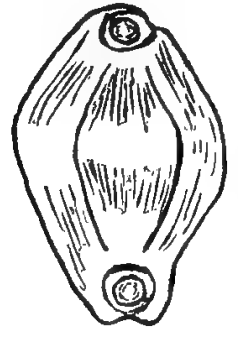

A.

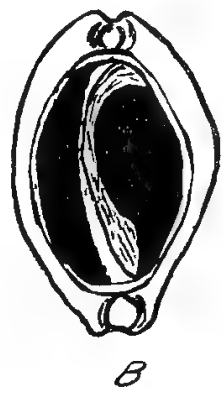

Oézula (Calpurnus) z'eryucosa L.

A.-Philippines (after keeve).

B.-Ancient American graves (after Holmes).

Mr. W. H. Holmes, in his "Alt in Shell of the Ancient Americans," 194 illustrates in Plate xxxii. a number of perforated marine shells exhumed from ancient graves of North America. Two of these (Figs. I I and I2) are of special interest as coming within the scope of the present discussion. Unfortunately the precise data regarding the site of their discovery are not given; all we are told is

19* Second Annual Report, Bureau of Ethnology, Washington, I 883 , pp. $179 \cdot 305$. 
that they are from the l'acific coast. Fig. I I shows a cowry with a small hole near each extremity, illustrating, it is stated (p. 220), "an ancient as well as a modern method of perforation." The name of the species is not given, but it does not appear to me to be an American shell. Though the illustration is not sufficiently clear to define the species, in general appearance and contour the shell has a look of Cyprac caput-serpentis-an Indo-Pacific species.

Holmes' Fig. I 2 (see Fig. $B$, p. I9 I) shows a shell rubbed down on the back, and is referred, like the last, to Cyprea; but this is incorrect, the shell being undoubtedly Ovula (Calpurnus) vernucosa, L. ${ }^{195}$ (Fig. A, p. 19I). This fact is of great importance and has hitherto passed unnoticed. Like the money-cowry, $C$. moneta, which it somewhat resembles, this species is alien to the American continent; it is known to occur only in East Africa, the Indian Ocean, Philippines, New Caledonia and neighbouring Islands.

According to Schmeltz (op. cit., I 894, p. 34), this shell is worn as a neck-ornament in the Viti, or Fiji, Islands; as a hip-ornament in Santa Cruz (Queen Charlotte Islands); and as a leg-ornament in East New Guinea. The Rev. A. H. Cooke ${ }^{196}$ also informs us that in Papua, "village elders are distinguished by a single Ovulum verrucosum, worn in the centre of the forehead."

The fact that the shell figured by Holmes is ground down on the back, as is done in the case of moneycowries in India, Africa, and other places, is of no little interest. Such an arbitrary method of perforation does

196 The well-defined tubercles at the extremities confirm this identification. Compare, Tryon's "Manual of Concholugy," vii., 1885, pl. 5, fig. 56-58 (Ovulidæ) ; Reeve, "Conchologia Iconica : Monograph of the Genus Ovulum," 1865, pl. i., fig. 2.

196 "Molluscs," Camb. Nat. II ist., vol. iii., London, I895, p. 99. 
not seem to have been usual in shells other than cowrieș, either in America or anywhere else.

It is remarkable that after so many years, and with the yearly increase of knowledge, the two shells figured by Holmes should have remained undetermined. They are reproduced along with the other shells of Holmes' plate by $\mathrm{H}$. Beuchat, on page-I45 of his "Manuel d'Archéologie Américaine" (Paris, I9I2), but no further details are added.

Regarding the use of cowries in Southern California, Frederick W. Putnam ${ }^{197}$ gives some interesting particulars, though these are somewhat lacking in detail. He writes (p. 252): "The fact that the Indians of California, in common with savages generally, often decorated their implements and utensils with the same materials which they employed for personal ornament, is proved by articles collected from the graves; as, for instance, the decoration of the rims of the large stone mortars, on which, held in place by asphaltum, are pieces of the pearly shell of Haliotis, or sometimes, the perfect shells of two or three beautiful species of Cypraa; C. spadicea particularly being employed on the mainland. Another method of ornamenting the rims of these mortars consisted in cutting away the dorsal portion of the shells of Cyprea and fastening them to the mortar, by their cut surface, with asphaltum, so as to exhibit the lips of the shell, with their serrated edges." Such a cut shell is represented by Putnam in Plate xiii., Fig. 52, of his work, but no specific name is given. Its contour is totally unlike that of C. spadicea, or any other American cowry. My colleague, Mr. R. Standen, and I have carefully compared the illustration with various cowries, and the only shell the features of which appear

107 In "Report U.S. Geog. Surv, west of Iooth meridian, vol. vii.Archæology," Washington, 1879. 
to conform to the illustration is $C$. vitellus, an IndoPacific species. This suggestion, however, can only be a tentative one, as comparison with the original specimen may reveal other distinguishing characters not visible in the illustration.

A further interesting feature is seen in Putnam's Plate (Plate xiii., Fig. 47-5 I) in the use that was made by the Californians of cowry-shells for personal adornment. The serrated lips of these shells were cut out and perforated at one end for suspension as pendants. Earlier in this Chapter reference is made to the discovery of the complete outer lip of a large cowry (C. tigris) in prehistoric pit-dwellings in the South of England (antea, p. I33).

The discovery of cowries in pre-Columbian graves in Ecuador is recorded by M. H. Saville. In his "Antiquities of Manabi, Ecuador," ${ }^{\prime 198}$ this writer reports the finding of a shell of the cowry-type, which had a hole drilled in the top, and a piece of pottery was fitted to the under part by means of some kind of gum. This shell, which is figured by Saville (Plate lxvii., Fig. 5) as Cypraca cervinetta (a Panamic species), was found with a human skeleton in mound 3 at Cerro Jaboncillo.

108 Contributions to South American Archæology, N.Y., I9IO, vol. ii., pp. 48 and 177 . 


\section{APPENDIX. I.}

Since the rest of this work has been printed further information bearing upon the matters discussed in it has come to my knowledge. Some of these data are of sufficient importance, especially from their bearing upon the problems of geographical distribution, to justify the writing of an appendix.

The discovery of the art of purple-dyeing has been attributed to the Tyrian tutelary deity Melkart, who is identified with Baal by many writers. According to Julius Pollux ("Onomasticon," i., iv.) and Nonnus ("Dionys.," XL., 306) Hercules (Melkart) was walking on the seashore accompanied by his dog and a Tyrian nymph, of whom he was enamoured. The dog having found a Murex with its head protruding from its shell, devoured it, and thus its mouth became stained with the purple. The nymph, on seeing the beautiful colour, bargained with Hercules to provide her with a robe of like splendour. He obtained the shell-fish, extracted the purple, and dyed for her the first robe of Tyrian purple, thus acquiring her favour. In the exergue of some of the coins of Tyre is represented this discovery of the purple-shell by the hound of Hercules.

In Coleman's "Mythology of the Hindus," (London, 1832), a remarkable picture is given (Plate 5, fig. 2) of the fish-incarnation of Vishru with an animal resembling a dog issuing out of a conch-shell at his feet. The association of a dog with Vishnu and his most sacred chank is hardly likely to have been invented by the worshippers of Vishmu, for to the Hindu the dog is unholy and an object of dread. This idea could hardly have originated in India itself, but was brought there along with a host of other bizarre conceptions.

In the legend of the discovery of the purple dye we have seen the mystic association (or companionship) of the god with the conch-shell and the dog. In the Indian picture we see a representation of the identical conception.

In the foot-notes to Rawlinson's "History of Herodotus" (London, I858, vol. ii., pp. 4r4-5, footnote 2), there is a reference to a shell in the hand of a statue of a 
Phœnician goddess [Astoreth ?], found by Mr. Moore in Syria. In Calmet's "Dictionary of the Holy Bible" ( 184 I, vol. 4, p. 37 ; vol. 5 , pl. liv., fig. 5), there is a figure of a Phoenician medal on which a female deity-halfhuman, half-fish-holds a concha marina, or sea-shell; in her left hand. It is impossible to identify the shells in these cases, but whether Buccinum or Murex, purple-shell or shell-trumpet, matters little. The chief point of interest is the association of a conch-shell with the deity-in one case a fish deity-recalling the like association of the chank with the Hindu god, Vishnu.

It is not a little curious to find that one of the purpleyielding shells (Purpura lapillus) is commonly known as the "dog-whelk." According to Lovell ("Edible British Mollusca," I 884), and other authorities, Buccinum undatum, L. is the common whelk, or buckie, the Ran and Buccinondé of the French. "In Anglo-Saxon whelk is IV eolc, but weolc is said to mean that which gives the purple dye (therefore it would apply better to the dogwhell, Buccinum lapillus, or Purpura lapillus, which yields a purple dye); thus, embroidered with purple is weolcbasn-hewen; scarlet dye is aveolc-read" (Lovell, op. cit., p. 200).

The following survival of an ancient method adopted in shell-fishing is worthy of note. At the present time whelks are taken in great numbers in wicker baskets baited with offal. Pliny ("Nat. Hist." bk. ix.) and Pollux ("Onomasticon," bk. i., ch. iv.) describe the taking of "purple fish" by a similar method, viz., in a kind of osier kipe, called Nassis, baited with cockles.

In dealing with the use of Triton shells for horns or trumpets in the Mediterranean region no mention was made of the practice of this custom nor of the presence of these shells in Ancient Egypt. I now find that the Triton was regarded by the Early Egyptians as an object worthy of a place among the articles deposited with their dead. J. de Morgan, in his "Recherches sur les origines de l'Egypte," records the discovery of two Triton-shells from the Red Sea (probably $T$. tritonis) in the Royal Tomb at Nagada, probably of proto-dynastic date. ${ }^{2}$ It

1. Pt. II., Ethnographie préhistorique et tombeau royal de Négadah, Faris, I897, p. r6o.

2 Firde Dr. G. Elliot Smith. 
is not stated whether they were perforated for use as trumpets.

In G. A. Wainwright's account of "The Excavations at Balabish," a number of objects are figured from "PanGraves," amongst them the Triton-shell, apparently not perforated, together with Strombus and other Red Sea forms.

These facts seem to suggest that in Egypt these shells must have served some definite cultural purpose, such as has been described ( $p$ 33) in the ceremonies observed in Crete and elsewhere in the Mediterranean.

Amongst a number of pamphlets entitled "Colonies Françaises," published by Ludovic Baschet, Paris, without date, there is an article by Max Leclerc on Madagascar, in which is given a coloured illustration of a Triton-shell trumpet, but whether it is "end-blown" or "side-blown" is not certain. The picture suggests the former. According to Ratzel, ${ }^{4}$ the musical instruments of the Malagasies "are eminently Malayan in character. The Antsiva or shelltrumpet of the Malays and Polynesians is regarded as very important. A great sea-shell, with a hoarse note, which only kings may legally use, serves to call the soldiers to arms."

Rumphius, writing in the early part of the I 8 th century, refers to the employment of Triton-shells, with a hole on the side of the spire, as trumpets by the Alfurs of Ceram. $\mathrm{He}$ also noted the use of great numbers of the white " eggshell"-Ovulum ovum-as ornaments for the neck and hair, by the same people.

In addition to the reference already given on $\mathrm{p}$. $5 \mathrm{I}$ of the use of shell-trumpets in the Babar Islands in calling down the sun-god to accept offerings, Mr. W. J. Perry has very kindly sent me a communication from Dr. A. C. Kruijt, of Posso, Central Celebes, stating that Triton-shell trumpets are much used in almost every village of Central and. North Celebes. They were formerly kept in the temple (20bo) together with strings of other shells. They

3 Journ. of Egyplian Archaology, Vol. II., Oct. 1915, pp. 202 et seq., pl. XXV., f. 2. "Pan-Graves" are Nubian interments in Egypt and may belong to the period from $2000 \mathrm{~B}$.C. onwards.

4 Ratzel, "Hist. of Mankind," vol. i., 1896, p. 457.

- G. E. Rumphius، "D’Amboinsche Rariteitkamer," Anısterdam, I74I, pp. 94 and II 5 . 
are taken on warlike expeditions and blown when an enemy has been killed. Sometimes bamboo trumpets are used. Some Toradjas say that bamboo is employed only when shells are not available. Shell-trumpets are also blown to warn the village of the approach of an enemy, and at eclipses of the sun and moon, when the temple drum is sounded; also when the bush is set on fire to clear it for agriculture. The employment of shelltrumpets at eclipses recalls their identical use in Bengal (p. 36):

Van der Sande, describes and figures two types of shell-trumpets in use in Dutch New Guinea. One of these is made from the Triton-shell, and is provided with a circular blow hole on the second whorl of the spire, outside the third varix; the other is made from the wingshell, Strombus maximus, and has the blow-hole at the apex of the spire, as observed by Moseley at Humboldt Bay (see p. 40). Both forms, according to Van der Sande, were offered to him inside a temple, "but had not to be concealed from the women. In fact they are also used outside, as also reported from elsewhere, as instruments of call, producing a very loud sound when blown. In British New Guinea [Fly River] they are used also to drive away evil spirits."

In his "Note on the Use of the Wooden Trumpet of Papua," W. N. Beaver gives some interesting references to shell-trumpets. "Naturally," so he says, "the coast tribes use the ordinary conch shell as a trumpet, and the people of the hinterlands obtain their shell instruments from them in the way of trade; but the further one penetrates inland, the more difficult it becomes to obtain shells."

He reports the use of the conch, together with the wooden trumpet, "among the Sangara on the northern side of Mount Lamington, among the Huhurundi living inland from Holnicote Bay, and among the Howajega, Asingi, and Tohani, all bordering about the main Kumusi River." In the trans-Kumusi region, towards

"Van der Sande, "Nova Guinea," III., Leyden, 19ग7, pp. 307-8, 314, pl. xxix, f. 22 and 24.

${ }^{7}$ Tbid., see also Chapter II., P. 4I, and Chalmers, in Journ. Anthrop. Inst., vol. 33 .

3 Man, Article I6, Feb., 1916. 
the Yodda Valley, among the Autembo and other tribes, the wooden trumpet is apparently used more frequently than the conch. "The ordinary conch shell trumpet varies in size up to about 20 inches long and about 9 inches across in the largest part [apparently Triton tritonis]. A hole from I inch to $\frac{3}{4}$ inch in diameter is made about 3 inches from the apex. Over water the reverberating note can be heard a very considerable distance."

The details of the notation of trumpet blowing, given by this writer, are of considerable interest. It is based upon the long-short blast system; and the significance varies according to the district. Examples are given of shell-trumpet calls from the Binandele tribes of the Mamba and Gira rivers, the significance of which, according to notation, are: "killing in a fight when in camp or dancing"; "calling to a fight"; "conveying the news of a death"; "men are bringing a pig." The second example, which consists of a "long blast, short, short, etc, and repeat," is generally used nowadays "to call in the people from their gardens, say, for example, on the arrival of European or other strangers, or, again, half-a-dozen long blasts may convey the news that a Government party or Europeans are approaching."

The use of shell-trumpets, in Peru, Samoa, and elsewhere, to herald the approach of some important personage, has already been described (antea pp. 45 and 46).

It is important to note that the photograph of the native blowing a wooden trumpet, reproduced by Beaver, shows the man wearing a string of large white "cowries" (Ovulum ovum).

From Malinowski's recently published account of the natives of Mailu Island, off the coast of New Guinea, ${ }^{9}$ it is apparent that certain shells, including shell-trumpets, play an important role in the "magico-religious" practices of these people. More especially is this the case at the Maduna, ${ }^{10}$ or great annual feast of the Mailu, which is connected, amongst other things, with agricultural activities. Elaborate preparations are made, and a number of

-Trans. and Proc. Roy. Soc. S. Australia, xxxix., Dec., 1915, pp. 494 seq.

10 Madina neans distribution, the allusion being to the distribution of foods which forms an essential feature of the proceedings (Malinowsiri, p. 665). 
minor feasts held, before the main feast, while certain forms of Góra, or taboo, are exclusively practised in connection with the same. The most important ceremonial role of one of the smaller feasts is the erection of a small gallows, ornamented with a large white shell called by the natives Móto (Ovulum ovum : the "so-called" white cowry). This is an indication that the Govi dance (the most important and most sacred dance) will be performed at the Maduna. It is also a token that as many pigs are already pledged for the feast as there are shells on the Gora, each shell representing one pig promised by a man of the Mladina gubina (master of the feast). The association of this shell with pigs is remarkable and perhaps significant, when it is recalled that cowries are widely known as pig-shells. By the French they are called Porcellana, or "pou-de-mer," and by the Romans porci and porculi.

Following this ceremony, according to Malinowski "comes the Oilobo feast, apparently the most important preliminary event, which certainly contains the greatest amount of magico-religious element, and probably even more than the main feast. It marks the beginning of the fasting or Udini period, and is held some two months before the main feast * * * This feast also is called Boróa evauré, Boróa meaning mango. In the morning of the feast-day a dance called Laige is performed in the village, both men and women taking part in it. The women hold * ${ }^{*}$ Elak $i^{13}$ in their hands, the men beat the drums and blow the conch-shells while dancing." It The later ceremonies take place in the afternoon, when the men go out into the bush, bringing back with them mango saplings and creepers, which form part of the pig magic. "They come in state, forming a procession, which is headed by a man blowing the conch (Bogígi) made of a Triton-shell. He is followed on both sides by two men, also with conch shells." The remainder of the procession

11 Góra, in its broadest and most abstract meaning, means taboo, rule, prohibition; it is distinctly the conception covering what we call law in our society. (Malinowski, p. 587).

12 See also Chapter IV., p. I26, 12 this subject.

18 Eláki: folded mats of pandanus leaves.

is Malinowski, op. cit., p. 670. 
is composed of the master, or masters, of the feast, and assistants bearing the mango saplings.

Before the holding of the main feast, word is sent round to the various villages, and the natives leave in their canoes for the ceremony, blowing conch-shell trumpets and shouting loudly to announce the event.

The ceremonial use of shell-trumpets by the Mailu in connection with agricultural and other activities forms a striking parallel to similar practices in Malabar and Siam, described in Chapter II., (p. 37). In Samoa, the Society, and other Pacific Islands, we also find shelltrumpets associated with processions and times of prayer and fasting. From Aztec pictorial manuscripts we learn that identical customs were carried out by the ancient Mexicans, as already noted in previous pages. The blowing of the conch-shell among the Guaymis of the Chiriquian region of Panama to announce the arrival of guests to a feast is another noteworthy example of identical usage ( $p, 47)$.

According to F. W. Christian, ${ }^{15}$ the "side-blown" shell-trumpet is also used in the island of Ponape, Caroline Islands. In describing the musical instruments of Ponapeans he tells us that "the Chaui (Fijian Davui) or shell-trumpet-the $P u$ of the South Polynesians, ${ }^{16}$ is used as a signal of war or assembly, like the Atabal of the ancient Mexicans. Close by the pointed end of the shell a circular hole is bored. Some of these are of very large size, and are often picked up amongst the foundations of old houses." Pearl-shell fish-hooks and Ovulurn ovumn are also used in this island; the latter as ornament for the prows of canoes.

Some details of the use of another cowry-like shellOvulum verrucosum - have already been given. I have since found that this shell is employed in New Caledonia as an ornament for witchcraft packets, great value being attached to the shell, especially for its believed powers of rendering persons invisible. ${ }^{17}$

I have been unable to trace the actual use of the Triton-shell as a trumpet in New Caledonia, but it is

15 Jourt. Anthrop. Inst., Vol. 28, p. 298.

10 For a good figure of this see Ratzel, op. c1l., i, p. 255.

17 Le Père Lamberl, "Moeurs et Superstitions des Néo-Calédoniens," Nouméa, I 900, p. 3 (Fig.). 
evident that it is regarded with some significance, as in the Berlin Museum there are three poles strung with Triton-shells from this island. ${ }^{18}$ In Ratzel's "History of Mankind" (vol. i., p. 260) there is a figure of one of these Triton-decorated poles surmounting the roof of a New Caledonian hut. It is interesting also to note that a bunch of Ovulum ovum shells is attached to the base of the pole. That the Orulum shell is regarded in Oceania as having an intimate connection with cosmogony is gathered from its association with the god Tangaroa, who is revered even in the remoter islands, such as Taaroa and Kanaloa. "A Raiatean legend gives a grand picture of his all-pervading power; how at first, concealed in an eggshaped shell, he hovered around in the dark space of air. until weary of the monotonous movement, he stretched forth his hand and rose upright, and all became light around him. He looked down to the sand on the seashore, and said: 'Come up hither.' The sand replied: 'I cannot fly to thee in the sky.' Then he said to the rocks : ' Come up hither to me.' They answered : 'We are rooted in the ground, and camnot leap on high to thee.' So the god came down to them, flung off his shell, and added it to the mass of the earth, which became greater thereby. From the sherds of the shell were made the islands. Then he formed men out of his back, and turned himself into a boat. As he rowed in the storm, space was filled with his blood, which gave its colour to the sea, and, spreading from the sea to the air, made the morning and evening glows. At last his skeleton, as it lay on the ground with the backbone uppermost, became an abode for all gods, and at the same time the model for the temple; and Tangaroa became the sky." 19

According to Pickering; war-conchs, made of Tritonshells, were met with at Aratika, in the western Paumotu Islands. In this group, aiso, and especially in Manihiki, ornamentation by means of pearl-shell is very characteristic, canoes and their paddles, clubs, and bowls, being inlaid with discs of this shell. ${ }^{.1}$ The associated use of pearl-shell and Triton-shell trumpets is also present in the

18 Bernice Tasthi Bishop Murseum, vol. i., No. i., Honolulu, 1898, p. 18.

1 ' Ratzel, ob. cit.. i., pp. 308.9.

20 "Races of Man" (Bohn's Ed.), 1850, p. 56.

${ }^{1}$ Bern. Pazhlz Bish. Mus., op. cit., various pages. 
Marquesas Islands, as well as elsewhere in the l'acific. In the Marquesas, skulls have the eyes replaced by pieces of pearl-shell, and the lower jaw fastened to the upper by cords, ${ }^{22}$ as in the islands of the Torres Straits.

One of the most important additions to our knowledge of the employment of shell-trumpets in ancient Peru is contained in Chas. W. Mead's article on "The Musical Instruments of the Incas." ":: The discovery in Peru of pre-Columbian trumpets made from the shells of Strombus galeatus has already been mentioned (p. 48). The pottery and other objects found in the ancient burial places of the Incas, and now transferred to the American Museum of Natural History in New York, has enabled Mr. Mead to provide more positive evidence of the use of shell-trumpets by the ancient Peruvians, for, certain of the artifacts, especially the pottery vessels, are decorated with pictures of human beings in the act of playing upon such instruments. Among other objects of interest described and figured by this author is a gold ornament found in a prehistoric grave at Ica, Peru, on which are depicted two human beings blowing trumpets. One of these is a shell probably intended to represent a Strombus: it is blown through a hole at the apex of the spire. A remarkably fine example of a shell-trumpet, "end-blown," made from Strombus galeatus, is also shown on Plate III. (fig. I) of Mead's paper; it has a copper mouth-piece, and is ornamented with an engraved figure of a warrior. Another figure on the same plate (fig. 2) depicts a trumpet made of terra cotta: it is one of several in the collection in which the shell form has been reproduced in clay. Classed with the flutes by $\mathrm{Mr}$. Mead are three other trumpcts. One is made from a shell (Frsciolaria princeps): it has two vents, one through the top of the spire, the other on its side, the two others being imitations of shells in terra cotta. The double perforation in the Fasciolariatrumpet is of very great interest as being the only example of its kind that I have met with in my researches.

The shell-trumpets of the Mediterranean region, of India, Borneo, China, Japan, and Central America, are all, so far as I have ascertained, "end-blown," $i . t$., they

2 2 Dall, in Butreau of Ethnology (United States), iii., 1884, p. 95.

23 American Mhesezun Jourmal (Supplement), Vul. III., No. 4, July, 1903, Guide Leaflet No. 11. 
have the tip of the spire of the shell knocked off. In New Guinea and in Melanesia "end-blown" trumpets are in use, as weil as others of the "side-blown" type, i.e., with the blow-hole on the side of one of the upper whorls of the shell. The apex in the latter is left perfect. It would appear, therefore, that the Peruvian example is a combination of the two types.

The reproduction of the shell form in clay is another interesting point linking Peru with the Mediterranean region. As mentioned on an earlier page (p. 34), clay models of the Triton-shell were found in 1903 in the excavations at Knossos, in Crete. Mosso also records the discovery in Minoan sites of reproductions of shells in alabaster and other materials. ${ }^{2+4}$

According to Mead, the trumpet is frequently mentioned in the earlier accounts of Peru, such as those of Garcilasso and Alonso de Ovalle, in connection with battles between opposing armies. Prescott also states that at the siege of Cuzco (1536) "the Spaniards were roused by the hideous clamour of conch, trumpet, and atabal, mingled with fierce war-cries of the barbarians." ${ }^{25}$

This association of the conch-shell trumpet with war was also met with in the lands bordering the north-eastern part of the Gulf of Mexico, for on the appearance of De Soto's soldiers in I 539 the Indians of Florida and the Chickasaw country were roused to action by the blowing of horns and conch-shells, and the beating of drums. ${ }^{-6}$

The custom of placing pearls and other objects in the mouth of the dead in China, described in an earlier chapter, is also found in Korea. In his article on "Mourning and Burial Rites of Korea," E. B. Landis ${ }^{27}$ gives a list of articles used at encoffining the corpse, which includes, amongst others; rice; pieces of Haliotis shell; three pearls, etc. A little rice is first placed in the mouth of the dead, then a pearl, in the left, the centre, and the right side of the mouth.

Dr. Elliot Smith informs me that in the course of

24 Mosso, "The Dawn of Mediterranean Civilization," I gro, p, $3^{64}$.

2 W. H. Prescott, "History of the Conquest of Peru," vol. II., 1855 , p. 32.

"Grace King, "De Soto and His Men in the Land of Florida," London, 1914, pp. 39 and 187.

"Journ. Anthrop. Inst., vol. 25, pp. 346-7. 
excavations in the Soudan Mr. F. Ll. Griffith found large numbers of cowries and metallic representations of cowries in graves at Napata and elsewhere, which are referred to Early Christian and pre-Christian times. Many of these cowries were rubbed down in the way so often mentioned in this book.

An interesting addition to the series of localities where the cowry is put to a cultural use is furnished by Ellis H. Minns, in his "Greeks and Scythians." ${ }^{28}$ In describing the contents of ancient Scythian graves in the Kiev district, he says: "Those who could not afford the precious metals used beads, either home-made of clay or stone, or of glass imported from the Mediterrancan area; even cowrie shells found their way so far north."

In his account of "Some Japanese Charms connected with the Making of Clothing," ${ }^{29}$ IV. L Hildburgh states that "a plentiful supply of clothing and the securing of good-fortune in general is thought to be assured by the placing of a cowry-shell (koyasugai) with the laid-away clothing, because, according to [his] informant, of the koyasugai's well-known significance as a symbol of good fortune, or by the placing of obscene pictures with the clothing." In further explanation of this remarkable custom he adds:- "I have been told by an informant from another part of Japan that people wishing to be lucky in lotteries sometimes carry pictures of the vulva (of which the cowry-shell noted above is a well-recognised image)." (See also antea, p. I83).

These additional scraps of information serve to emphasise the general conclusions that emerge quite definitely from the mass of data impartially set forth in this book. All the cultural uses of shells are intimately related the one to the other. In whatever part of the world shells are employed for such purposes, the same peculiar and wholly arbitrary significance is attached to them. They confer the blessings of fertility in women and crops. They cure sterility and facilitate parturition. They bring good-luck in games and more serious enterprises. They avert the evil eye. They secure the preservation of the clead and bring resurrection and life. They

as Cambridge, r913, p. 64, quoting Count A. A. Bokriı skuj, "Smêla," ii, v., I.

29 Man, Fel., 1917, 17 . 
are the parents of mankind and the dwelling-places of gods. They can summon the gods to be present at ceremonies of initiation, at deaths and burials, in battle and in harvesting. Whether as cowry-amulets or blasts upon the shell-trumpet they are used to convey messages of war and death, or to summon the people from agricultural occupations, or to greet important strangers. As medicine they can restore the "soul-substance," the loss of which is responsible for illness or death.

These remarkable attributes of shells are found widespread in the Old World and the New, and afford the most positive and unequivocal evidence of the migration of early culture along certain well-defined routes around the earth. 


\section{APPENDIX II.}

\section{The following interesting information has reached us as we are going to press.}

What appears to be an additional instance of the cultural use of the money-cowry in the New World is to be seen in a picture reproduced by S. H. C. Hawtrey, in "The Lengua Indians of the Paraguayan Chaco."1 In Figure 2 (p. 282) this writer shows the head of a Lengua Indian with a remarkable headdress on which money-cowries are distinctly visible arranged in rows. No reference to these is made in the text. iSuch a type of cowry-ornamented headdress recalls those of the East African people described in Chapter IV. (p. I42) of this book.

- That shells were cult-objects in early times in Egypt seems certain, from their occurrence in numbers in ancient Egyptian sites. But to little attention has been paid to these discoveries and their true significance has not been appreciated, investigators having too little knowledge of shells and their habitats to realise the importance of their presence in ancient tombs. Nearly all the shells recorded as found in Egyptian tombs are species which inhabit the Red 'Sea and the adjacent African coast. $H$ Hence it is probable that all these shell-cults had their origin in this region, that is they were developed by a maritime people, or people having ready access to the sea. Suggestive evidence of this is furnished by the fact that Red Sea' Pteroceras-shells (Pteroceras bryonia, Gmelin) figure as designs on statues of the phallic god Min found on the site of the temple of Kopitos. Some authorities think these statues belong to the Predynastic period, but others, regard them as the earliest work of the dynastic people. Their presence at Koptos has been claimed as providing "a powerful argument to those who wish to bring the dynastic Egyptians from the land of Punt, situated on the east coast of Africa, on the borders of the Red Sea."2 But diffusion of culture can explain the facts without dragging into the discussion these purely hypothetical and utterly misleading

1 Journ. Anthrop. Inst., 3 I, I gor, pp. $280 \mathrm{et} \mathrm{seq.}$

Petrie, "Koptos," I 896, pp. 7-9, pl. iii., iv. ; also Capart, " Prinitive Art in Egypt," I905, pp. 222-224, figs. I66-167. 
interpretations. of the racial problem. There are many indications of intercourse with the East African littoral in Proto- as well as in Predynastic times.

Whatever view is taken as to the source and date of the Min statues, it does not in any way affect the question of the introduction of sea-shells into Egypt: as these were already in use there in Predynastic times. Whether originally brought by migration of people or introduced by trade relations, does not concern us in this discussion, but the evidence at our disposal points very definitely to the Red Sea coast as the chief source of supply. Thus there must have been some kind of intercourse between Egypt and this region at a very early period. But strange as it may seem, there is as yet no rearlier evidence than the Sixth dynasty for the use and appreciation of the marine pearlshell, though hosts of other Red Sea shells had been in use for centuries before that date.

Of extraordinary interest is the presence in Egypt of mummified shell-fish. Lortet and Gaillard ${ }^{3}$ report the discovery of two shells (Arca auriculata, Lam. and Cardium edule, L.) prepared "pour la momification par le natron résineux conservateur" in a tomb of the necropolis of Gébélên, in Upper Egypt. These must have been carried across the desert from the shores of the Red Sea in a mummified istate, since it would not have been possible for them to have remained in a fresh condition in so warm a climate during the journey to Gébélên.

The full significance of the role played by shells in the religion of the Egyptians awaits elucidation, but it is certain that some symbolic virtues were assigned to them. They may have been associated with some deity, just as we have seen the cowry to be associated with Venus. Doubtless a closer study of Egyptian texts and monuments would result in elucidating this interesting subject.

3 Arch. Mus. d'Hist, Nat. de Lyon, vol, Io, 1909, Pp. I16-I I7. 


\section{BIBLIOGRAPHY OF OTHER RECENT MEMOIRS DEALING WITH THE THEOKY OF THE MIGRATIONS OF EARLY CULTURE.}

A.-The following Papers on the Theory of the Migrations of Early Culture have been published by Professor G. Elliot Smith :-

I. "The Ancient Egyptians and their Influence upon the Civilisation of Europe," Harper Brothers, London and New York, I9I1. 2/6 net.

2. "Megalithic Monuments and their Builders," Report, British Association, 1912, p. 607.

3. "The Evolution of the Rock-cut Tomb and the Dolmen," in "Essays and Studies presented to William Ridgeway," Cambridge University Press, I9I3, p. 493.

4. "The Migrations of Early Culture," Manchester University Press, 1915. 5/- net.

5. "The Influence of Ancient Egyptian Civilisation in the East and in America," Manchester University Press, I9I6. I/- net.

6. "The Origin of the Pre-Columbian Civilisation of America," Science, August IIth, I9I6, p. I90.

7. "Pre-Columbian Representations of the Elephant in America," Nature, November 25th and December I6th, I9I5, and January 27th, I9I6.

8. "Ships as Evidence of the Migrations of Early Culture," Manchester University Press, 1917. I/- net.

\section{TO BE PUBLISHED SHORTLY.}

9. "Incense and Libations" and

I0. "Dragons and Rain-Gods," in the Bulletin of the John Rylands Library, and also separately, Manchester University Press.

I I. "Primitive Man," in the Proceedings of the British Academy, Oxford University Press, 1917. 
B.-Other Publications on the same subject issued by the Manchester University Press :-

(I) Memoirs by W. J. Perry.-

"The Megalithic Culture of Indonesia," with illustrations. (In the press.)

"The Relationship between the Geographical Distribution of Megalithic Monuments and Ancient Mines," Memoirs and Proceedings of the Manchester Literary and Philosophical Society, November 24th, I9I 5. I $/ 6$ net.

"The Geographical Distribution of Terraced Cultivation and Irrigation," ibid., April I5th, I9I6. I $/ 6$ net.

(2) Memoirs by J. Wilfrid Jackson.-

"The Money Cowry as a Sacred Object among North American Indians," ibid., May I7th, I9I6.

I/- net.

"The Aztec Moon-cult and its relation to the Chank-cult of India," ibid.. May I7th, I9I6. I/-net. *"s The Geographical Distribution of the Shell-Purple Industry," ibid., May 22nd, 1916. 1/6 net.

*"Shell-Trumpets and their Distribution in the Old and New World," ibid., May 22nd, 1916. I/6 net. *" The Geographical Distribution of the use of Pearls and Pearl-shell," ibid., September 6th, I9I6. I $/ 6$ net.

*" The Use of Cowry-shells for the Purposes of Currency, Amulets, and Charms," ibid., December, I9r6. $2 / 6$ net.

*Reissued with new plates and additional information in "Shells as Evidence of the Migrations of Early Culture." Price $7 / 6$ net. 


\section{INDEX.}

Amulets. See Cowries.

Aztec gods. Shells associated with, 5I-55; compared with Hindu gods, 53-55, 57-58, with Maya gods, 56-57; adorned with pearls, II8. See also Tecciztecatl, Tlaloc, and Tonatiuh. Aztec Moon-cult, 35, 52-55.

Babylonian Fish-god, 61, 78 .

Blood-letting. Shell-trumpets used at, $5 I$; cowries used at, 160 .

Buccinum-shells, as trumpets, 4, 32 ; purple dye obtained from, 4-7, I96. See also Purpura-shells.

Cassis-shells, as trumpets, 38-40, 43, 51 ; found in Mentone cave, 136 ; found in pre-Columbian burial in Ecuador, I2I.

Chac, Maya Rain God. Conch-shell associated with, 57 ; compared with Tlaloc, the Mexican Rain God, 57 ; appears as the Maya Moon God, 57 ; claimed as the American form of the Vedic god, Indra, 57-58; tortoise associated with, 60 ; compared with the stag-headed dragon in Japan, 63 . Chank-cult of India, 35-38, 53-55, 58 . 59, 195-196.

Chank shells. As trumpets, 35-38, 5355 ; used by Hindus and Buddhists, $35,38,53-54$; reversed, prized by Hindus, 35 , by Chinese, 38 ; Vishnn associated with, $35,53,58-59,6 \mathrm{I}$,

- 195-I96; calcined for making lime, 84, 9I-92; references in Classics to, 88; fisheries of, 88-89; pearls found in, 90; in prehistoric sites in India, 164-165; bangles made from, 165 .

Charms. See under Cowries.

Circumcision. Shell-trumpets used at, $37 ;^{\circ}$ cowries used at, I59.

Classical Literature. Purple mentioned in, 3-4, 7, IO-I 5, 8I, I95; shelltrumpets mentioned in, 30, 32; pearls mentioned in, $73,77,81,83,87-88$, 93-94, 96, 104.
Clay idol found in Cassis-shell in Tennessee, 64.

Clay models of shell-trumpets, 34,47 . 203-204.

Cowry, The. Derivation of name, I 26; Greek name of, r26; Roman name of, 1 26, 200; French name of, 126, 200 ; Sanskrit name of, I26; Portuguese name of, I26; Arab name of, I26; Siamese name of, 126; Chinese signs for, I80-182; Japanese name of, $183,205$.

Cowry-shell, The. Known as "Concha Venerea," I38; as the parent of mankind, 176; as the source of life, I82-I83, I85-I86. See also Cowries.

Cowries. Death, associated with, 74, I OO, I 28 -I 38 , I 45, I 47, I 53-I 54, I 59I61, I64, I69-I70, I 82-I 83, I 86- I 94, 205; placed in mouth of the dead, I00, 182-183, 186; as currency, 123, I 26, I 30, I 40, I 42, I 47-I 64, I65-I 69 , I 71, I 74-I75, I77-I8I, I83; as amulets, I $23,127-129,139-143,146-164$, 169-172, 183, I94, 205-206; in games, I 26, I 54, I 57, I 59, I 70-I 7 I : as hunting and fishing charms, 127 , I 57-I 58, I73-I74; as charms against the evil eye, I27, $140,1_{52-1} 53,158$, I69, I83; as fertility charms, I 27 , I $33, I_{39}, I_{42}, I_{45}, I_{52-I} 53$, I 57 -I 58 , I70, I83-I 84; marriage, associated with, I 27, I 42, I 45-I 46, I 53, I 57 , I64, I72; imitated in stone, I 28 , I74, in ivory, 176 , in metal, $1_{7} 8$, 205; in caves, 134-138; for divination and soothsaying, I $40-I_{4} I, I_{45}$, I 55, I 58-159, I6I, r70; headhunting, associated with, $\mathbf{r}_{42} 2, \mathbf{I} 60$, I72, I74; as eyes for idols, I49-I 50, $158,173,176$; initiation ceremonies, associated with, I 54-I 55, I84-I 86; at circumcision, I 59 ; as symbolic messages, I6I-I63, I90-I9I; as warsignals, I6I, 190-191.

Cowries. Use of : Africa, I4I-I64; America, N., I84-I93; Arabia, I39; Bosnia, I3I; British Isles, 133, I40, 
194; California, 193-194: Caucasus, I 30-I3I: Ceylon, I70; China, I77I 83; Crete, I34; Ecuador, I94; Egypt, 74, I 28-1 30, I38, I 40-I 4I, I63, 205; France, I33-I35; Germany, I30-I34; Greece, I40; Hawaii Islands, 174; Hungary, I40; India, I40, I64-I 70; . India, Further, I 7 I I72; Indonesia, I 72-I 74; Italy, I 33, I 36-I 37; Japan, I83-I 84, 205; Maldives, I67-I 68, I7 I; Melanesia, I75; Micronesia, I75; Montenegro, r40; Norway, I40; Nubia, I28-I 29 ; Paraguay, 207; Persia, 140; Philippines, I74; Polynesia, I75-I76; Russia, I3I, I39, 205; Sicily, I 39; Spain, I34; Sweden, I30; Thibet, I 72.

"Crab-stones," or "crab's eyes," 92, 96.

Crete. Early discovery of shell-purple in, 9; early use of shell-trumpets in, 33,61 ; cultural use of cowry in, I34.

Currency. See Cowries; also Pearis, Haliotis, and Tortoise-shells.

Death. Shell-trumpets associated with, 37-38, 4I, 44; pearls ditlo, 89-9o, IO0-IOI, I06, II2-II7, 204; cowries ditto, 74, 'I00, I28-138, I45, I47, I 53-I 54, I 59-I6I, I64, I69-170, I 82, I 83, 186-194, 205.

Divination. Cowries used for, I40-I4I, I 45, I 55, I 58-I 59, I6I, I 70; tortoise used for, I82.

Dog, The. Unholy to the Hindu, I95; associated with Hercules (Melkart), 195, with Vishnu, I95; whelk named after, I 96.

Dragon, The. Stag-headed, in Japan, 63; emerging from conch-shells, 6768; pearls essociated with, 102-104.

Early purple-fishery, 9, 195.

Ear-piercing. Shell-trumpets used at, 51 .

Evil eye, charms against. See Cowries. "Eye-stones," or opthalme, 92.

F asciolaria-shells, as trumpets, 50-5I, 203; associated with Mexican gods, 5 I-52; associated with Maya gods. 56.

Ferliity charms. Sce Cowries.
Fish Incarnations. See $V$ ishnu.

Fishing charms. See Cowries.

Fog-horns. Fusus-shells used for, 39 .

Fresh-water pearls. See Pearls.

F 2 sus-shells, as trumpets, 39-40; found in Japanese shell-mounds, 19.

Gaetulian Purple, 15.

God in the Shell, 44, 52-58, 64-68, I77.

Gods represented by shell-trumpets, 44 . Games. See under Cowries.

\section{Haliotis-shell. Known as Ear of Venus,} xii; as currency, xii; cultural use of, 49, I06-107, I 10, 122, 193; pearls found in, 106-107, 122; found in ancient burials, 122; placed in mouth of dead, 204.

Harvest-rites. Shell-trumpets used at, 36-37, 49-5I, 54, I98-20I.

Head-hunting. Shell-trumpets associated with, 4I; cowries associated with, I 42, I60, I 72, 174 .

Hercules (Melkart). Discovery of purple dye attributed to, 195; dog associated with, 195.

Hindu chank-cult, $35-38,53-55,58$ 59, $195-196$.

Hindu gods. Shells associated with, $35,53-55,58-59,6$ I, 195-196; compared with. Aztec gods, 53-55, 57-58, with Maya gods, 58-6I, with Japanese gods, 62-63; tortoise associated with, 59-60; adorned with pearls, 87 . See also Vishnu, Siva, Indra, and Varuna.

Human beings emerging from shells, $55,62,65-67$.

Hunting charms. See Cowries.

Indian Fish-god. See Matsya.

Indra, Vedic god, 58, 68; compared with Tlaloc, the Mexican Rain God, 58, with Chac, the Maya Rain God, $57-58$.

Initiation. Shell-trumpets associated with, $4 \mathrm{I}-42$; pearls and pearl-shell associated with, 87 ; cowries associated with, I 54-I 55, I 84-186.

Japanese god, Shell associated with, 62; fish incarnation of, 62; compared with the Hindu god, Vishnu, 62-63; tortoise associated with, 63 . 
Kava drinking and shell-trumpets, 4I42.

Krishna. An incarnation of Vishnu, 59; discovery of pearls attributed to, 87 ; Panchajanya, conch-shell trumpet of, 59 .

Kurma, tortoise incarnation of Vishnu, $59-60,63$.

\section{Laconian Purple, I2.}

\section{Marine pearls. See Pearls.}

Marriage. Shell-trumpets associaled with, 32, 37; pearls ditto, 70, 8I. 82 ; cowries ditto, I27, I42, I45-I46, I53, I 57, I64, I72.

Matsya, fish incarnation of Vishnu, 58-59, I 95 .

Maya gods. Shells associated with, 55-58, 68; compared with Hindu gods, 58-6I, with Aztec gods, 56-57; tortoise associated with, 6o. See also Chac.

Maya manuscripts. Shells figured in, $55-58$

Maya Rain and Moon God. See Chac.

Medicine. See Pearls; also Pearl-shell.

Megalithic Culture. Purple associated with, 14, 25, 27-28, 72 ; shelltrumpets associated with, I4, 25, 27, 29, 72; pearls associated with, I4, $25,27,29,72,77,90$; cowries associated with, 74 .

Mexican manuscripts. Purple dye used in, 25-26; shell-trumpets figured in. 50-55.

Mexican Moon God. See Tecciztecatl.

Mexican Rain God. See Tlaloc.

Minoans. Invention of purple dye attributed to, 9; shell-trumpets used by, 33-35, 6I; shell-trumpets figured on seals of, 33-34; shell-trumpets found in Sanctuaries of, 35 .

Money-cowry, The. Regarded as sacred by North American Indians, I84- I86; found in N. American mounds, I86. I90. See also Cowries.

Moon, The. Conch-shell as emblem of, 52 ; influence of, on women, 52, 69, on crops, 53, on shell-fish, 68-69; Hindu god of, 53-55; Aztec god of, 56; Maya god of, 57; Japanese god of, 62 .

Mother-of-Pearl. See Pearl-shells.

Mummified shell-fish found in Egypt, 208 ,
Murex-shells. Furple dye obtained from, 5-6, 9, 12-14; used as symbol on Tyrian coins, 5, 195; used as trumpets, $35,49-50$.

Mycenæan use of Triton as ornament, 34 .

Mytilus-shells. Pearls found in, 89, Io8.

Ovulum ovum (Indo-Pacific shell). In Gothlandic tomb, I34; as canoe ornament in the Pacific Islands, I75, 20I; associated with use of shelltrumpets, I99-200; Móto, the Mailu name for, 200; in "pig-magic" in New Guinea, 200; Raiatean legend of its association with the god Tangaroa, 202; on Triton poles in New Caledonia, 202.

Ouulum verrucosum (Indo-Pacific shell). In Californian graves, I92; as an amulet in Pacific Islands, I92; rubbed down on back like moneycowry, I92; as ornament of witchcraft packets in New Caledonia, 2oI.

\section{Panchajana. 59.}

\section{Panchajanya. 59.}

Pearls. Megalithic Culture associated with, I $4,25,27,29,72,77,90$; commerce in, $70,72,77,88-89,93$ 95, 97-99, I $07-109$, I $12-$ I I 3, I 20 ; superstitious reverence of, $70,8 \mathrm{I}$, $86-87,92$, Ioo-ro3; medicinal use of, $70,89,91$, IOI; said to be con- . gealed dew-drops, $70,72,81,85$, 9o, I 20; as symbols of purity, 70; Phonician influence and the appreciation of, $72-73,76,79,82,84$ $85,95,97-99 ;$ artificial production of, 73, I04-106, II3; references in Classics to, $73,77,81,83,87-88$, 93-94, 96, I04; as earrings, 75, 78-8I, 87-88, IO9, I I 5, I I 9-I 20; influence of thunderstorms on breed. ing of, 77 ; in nose-rings, 78,80 , I20; solar origin attributed to, 78 ; on coins, $79-80,83$; drilling of, 80 ,

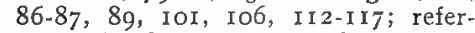
ences in Scriptures to, 82; colour of, $83,86-87,94$, I06; discovery of, attributed to Krishna, 87; as eyes for idols, 87; associated with sharks, 88, I04; in making lime, 89 , 9I, 93-94; placed in mouth of dead, 89-9o, IOO-IOr, I06, II 4, 204; as 
currency, 95, I I5, I78; supposed germination of, 95 ; associated with dragon-protectors, I02-IO4; in North American mounds, II2-II7; as "eggs" of shell-fish, I2I.

Pearls. Use of: America, North, II2I 77; America, Central, II7-I I8, I 20; Assyria, 78; Astrakhan, 80; Babylonia, 78-79; British Isles, 83-84; Ceylon, 93; China, 95-106; Crimea, 80; Cyprus, 79 ; Ecuador, I2I ; Egypt, 75-76; Europe, 85-86; Greece, 79-8o; India, 87-89; Italy, 8I-83; Japan, I06; Korea, 204; Malay Archipelago, 94-95; Mexico, II8I20; Pacific Islands, Io9; Palestine, 82; Persia, 78; Peru, I2 I; Siberia, Io9; Syria, 79; Venezuela, Izo.

Pearl-Fisheries. Africa, East, 76-77; Alaska, I 22; America, North, I I 2I 7 ; British Isles, $83-85$; California, II8; Ceylon, 93; China, 9699; Ecuador, I 2 I ; Europe, 85-86; India, 88-92; Japan, Io6-IO7; Kamtchatka, I08; Manchuria, I07-108; Malay Archipelago, 94-95; Mauritania, 76; Mediterranean, 83; Mergui Archipelago, 94 ; Mexico, II8; Pacific Islands, IOg-II2; Panama, I20; Persian Gulf, 77-78; Red Sea, 73; Siam, 99-100; Siberia, I09; Venezuela, I 20.

Pearl-shells. Medicinal use of, 7O, 9I, IOI; in graves, $74,77,84$, I IO, I 22: commerce in, 74-75, 88-89, 93-95, 98-99; as breast ornaments, 74-75, III-II3, I I8-I 20; receptacles for paint, 76; in making pottery, 84 ; calcined for making lime, 84, 9I; superstitious reverence of, 87,92 , IO9-II 2; as fish-hooks, IOg-IIO, 2OI ; as temple offerings, IIO-III; as eyes for idols, III, II9; as eyes for mummies, II I, 203.

Pearl-shells, Use of : Alaska, I22; America, North, I 7 ; British Isles, 83-84; California, I22; China, 9899, IOI; Ecuador, I 2 ; Egypt, 73. 75; India, 87; Italy, I4, 82; Malay Archipelago, 94-95; Mexico, I I9-I 20: Nubia, 74; Pacific Islands, IO9-I I 2, 2OI-203; Palestine, 82; Peru, I2I; Rhodesia, 77, 84; Siam, Ioo.

Pearl-shell fish-hooks. As currency, i Io: used for transmitting messages, I Io.

Phonicians. Purple trade by, 3, 5, IO-12, 14, 93; discovery of purple dye attributed to, 9, I95; purple dye manufactured by, 6-7, 10-13, 17; pearl-fisheries inaugurated by, $72-73$, $76,84-85$, 99; pearl trade by, 79 , $82,97-99$; known to Chinese as Hormuzian or Hwang-tchi (yellowfingered) sea-traders, 99; skilled in drilling pearls, I06; goddess of, with conch-shell, I96.

Placuna-shells. Fisheries of," 89, 93, 95, 107; pearls found in, 89,93 , 95, 107.

Pregnancy. See Cowries; also Snailshells.

Pteroceras-shells, as cult-objects in Egypr, 207; associated with phallic god Min, 207; as trumpets in India, 38.

Purple Dye. Chief centres of production: America, Central, 20-24; America, South, 2I, 25-27; British Isles, I 5I7; Mediterranean, Io-I5; Mexico, 23-26.

Purple Dye. References in Classics to, $3,4,7$, Io-15, 81, 195; trade in, by the Phonicians, 3, 5, 10-17; process of dyeing, 3, 6, 21-25; methods of extraction, 3, 2I-25; photogenetic property of, 4, 5, 23; references in Scriptures to, 7, II; as paint, 8, I 8 , I 9, 25, 26; as rouge, 8, 26; probable first discovery in Crete, 9; associated with megalithic culture, I4, 27-28.

Purple Dye. Molluscs whence derived; Buccinum, 4-7, 196; Murex trunculus 5, 6, 9, I 4; Murex branderis, 5, 6, I2, I3; Purpura lapillus, 4, 5, 6, I5, 16, I96; Purputa hamastoma, 5, I3, I4, 20, I34; Purpura patula, 20-21.

Purple Dye. Use of: America, Central, 20-24; America, South, 21, 25-27; Babylonia. 7; British Isles, 4 5. I5-18; China, I9; Egypt, 7, 9, I1; France, I4, I8; Japan, I9, 20; Malaysia, I9; Mediterranean, 3, 7, 8, I 4, 20, 8I, I 34, I95; Mexico, 2326: Norway, 18.

Purple robes, 7, I8, 24-26, 87, 93, 97, I95.

Purple-shell. On Tyrian coins, 5, I95; found in caves, 13, I4, 82. See also Purple dye.

Purple-shell fisheries. See Purple dye, centres of production.

Purpura-shells, purple dye obtained from, 4-6, 13-16, 20-21, 134, I96. 
Ranella-shells. As trumpets, 40.

Scriptures. Purple mentioned in, 7, II ; pearls mentioned in, $8 z$.

Seed-pearls. See Pearls.

Shell God. Spe God in the Shell.

Shell-purple. S.ee Purple dye.

Shell-money. Siee Cowries.

Shell-mounds, British Isles, I5, 16; Chile, 26; Japan, I9; Mediterranean, 6, 9-I3.

Shells regarded as the birth-place of human beings, $65-67$, I76-I77; regarded as the dwelling place of the deity, 44, 64-66, I 77, 202 .

Shell-trumpets. Cave discoveries of, I3, 34-35, 82; on coins, 30; references in Classics to, 30,32 ; as warsignals, $30,33,39,41,44-46$, I 97 $199,202,204$; in religious ceremonies, $32,33,35-36,44-45,47-51,54,66$, 198-20r; at marriage ceremonies, 32, 37 ; in summoning the divinity, 34, $35,5 \mathrm{I}, 197$; in harvest rites, 36-37, 49-5I, 54, 198-20I; in devil-driving, $36,37,4 I, 43$, I98; at eclipses and earthquakes, 36 , 198; at death ceremonies, $37,38,4 \mathrm{I}, 44$, I99; in foundations of old houses in Ponape, 20r. See also Initiation, Kava drinking, Head-hunting, etc.

Shell-trumpets. Shells used for: Buccinum, 32; Cassis, 38; Cassis cornuta, 40, 43, 5I; Cassis tubero. sum, 39; Fusus, 39; Fusus proboscidiferus, 40; Fasciolaria gigantea, 50, 5I; Fasciolaria princeps, 50; 203: Murex (Phyllonotus) radix, 49, 5o; Murex trunculus, 35 ; Pterocera, 38; Ranella lampas, 40; Strombus, 40; Strombus galeatus, 48, 49, 203; Strombus gigas, 47; Strombus goliath, 48 ; Strombus maximus, I98; Triton nodiferus, 3o, 32-34; Triton tritonis, 39-45, 197-202; 7'urbinella pyrum (the Chank), 35-38, 53-55; Turbinella scolymus, 50 .

Shell-trumpets. Use of : America, Central, 47, 203; America, North, 48-49; Brazil, 48; British Isles, 32; Ceylon, 38 ; China, 38-39, 203; Corsica, 33; Crete, I4, 33, 204; Elba, 33; France, 33; Greece, 30; India, 35-38, 53-55, 203; Indonesia, 39-4I, I97-201, 203; Italy, I 4, 32; Japan,
39, 203; Laccadive Islands, 38; Madagascar, I97; Melanesia, 4I-43, 204; Mexico, 49-53; Micronesia, 46; Peru, 46, 48, 203-204; Philippines, 40; Polynesia, 4I, 44-46, 197, 20I203; Russia, 32; Sicily, 32-33; Siam, 37; Thibet, 38 .

Siva, Hindu god. Chank shell associated with, 53 .

Snail-shells. Pregnancy associated with, $52,54,5^{6}$; superstitious reverence of, 92.

"Snail-stones." 92.

Strombus-shells, in Egyptian graves, I97; as trumpets, 40, 47-49, I98, 203; pearls found in, 90 , note 56 .

Superstitious reverence of shell-trumpets, 44,66 ; of pearls, $70,81,86-87,92$, IOO-IO3; of snail-shells, 92 .

Tecciztecatl, Mexican Moon God. Conch-shell associated with, 52, 56; compared with $V i s h n u, 53-55$; compared with Maya Moon God, 56 .

Tlaloc, Mexican Rain God. Conchshell associated with, 52, 54, 57; compared with Varuna, the Hindu god of the waters, 54; compared with Chac, the Maya Rain God, 57; claimed as equivalent to the Vedic god, Indra, $5^{8}$.

Tonatiuh, Mexican Sun God, associated with fasting man blowing shelltrumpet, 51 .

Tortoise, The. Anthropomorphic figures of, 56; Vishnu associated with, 596o; Maya gods associated with, 6o; Japanese god associated with, 63; Chinese symbol for, I8I-I82; used for divination, I82.

Tortoise-shells. As currency, 130, 178I 82.

Totemism and shell-trumpets, 42 .

Triton, Neptune's trumpeter, with conch, 30.

Triton-shells. As symbols on Tyrian coins, 5; in caves, $\mathrm{r} 3,34-35$; as trumpets, 30, 32-34, 39-45, r97-202; on Minoan seals, 33-34; as designs on Mycenæan pottery, 34 ; clay models of, 34; in Minoan Sanctuaries, 35; in Egyptian graves, I96-I97; on ceremonial poles in New Caledonia, 202;

Tridacna-shells. Pearls found in, xii; axes and other tools made from, xii. 
Turbinella-shells, as trumpets, $35-38$, 5o, 53-55; see also Chank shells. Tyrian Purple. See Purple dye.

Varuna, Hindu god of the waters. Chank shell associated with, 53-54; compared with Tlaloc, the Mexican Rain God, 54; characters of, assumed by the Vedic god, Indra, 58.

Venus. Haliotis-shell known as Ear of, xii; cowry-shell consecrated to, xii; shell associated with birth of, 55; British pearls dedicated to, 83; cowry-shell known as "Concha Venerea," the shell of, 138 .
Vishnu, Hindu god. Chank shell associated with, $35,53,58-59,61$, 195-196; incarnations of, 58-60, 63, I95; dog associated with, I95; compared with Mexican gods, 53-55, with Maya gods, 58-6I; with Japanese gods, $62-63$.

War-signals. Shell-trumpets used as, 30, 33, 39, 4I, 44-46, I97-199, 20I202, 204; cowries used as, I6I, I90I9I.

White cowry. See Ovulum ovum. 
, 





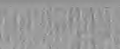

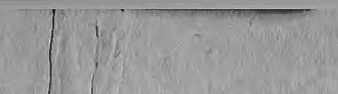

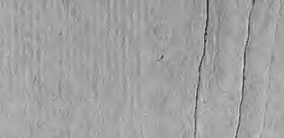

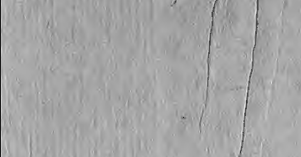

$\sqrt{x+2}+x$

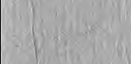
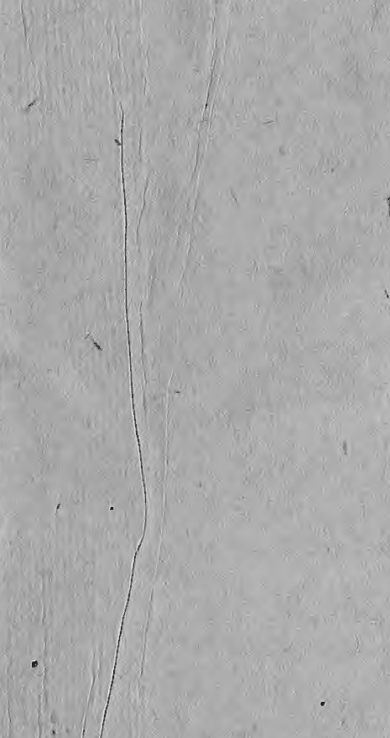

I.

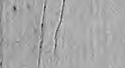

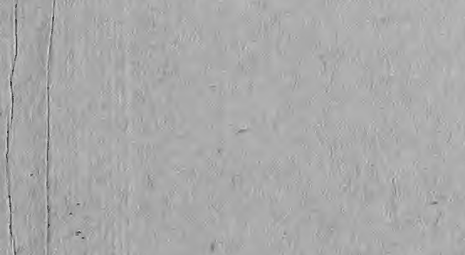

( 
